
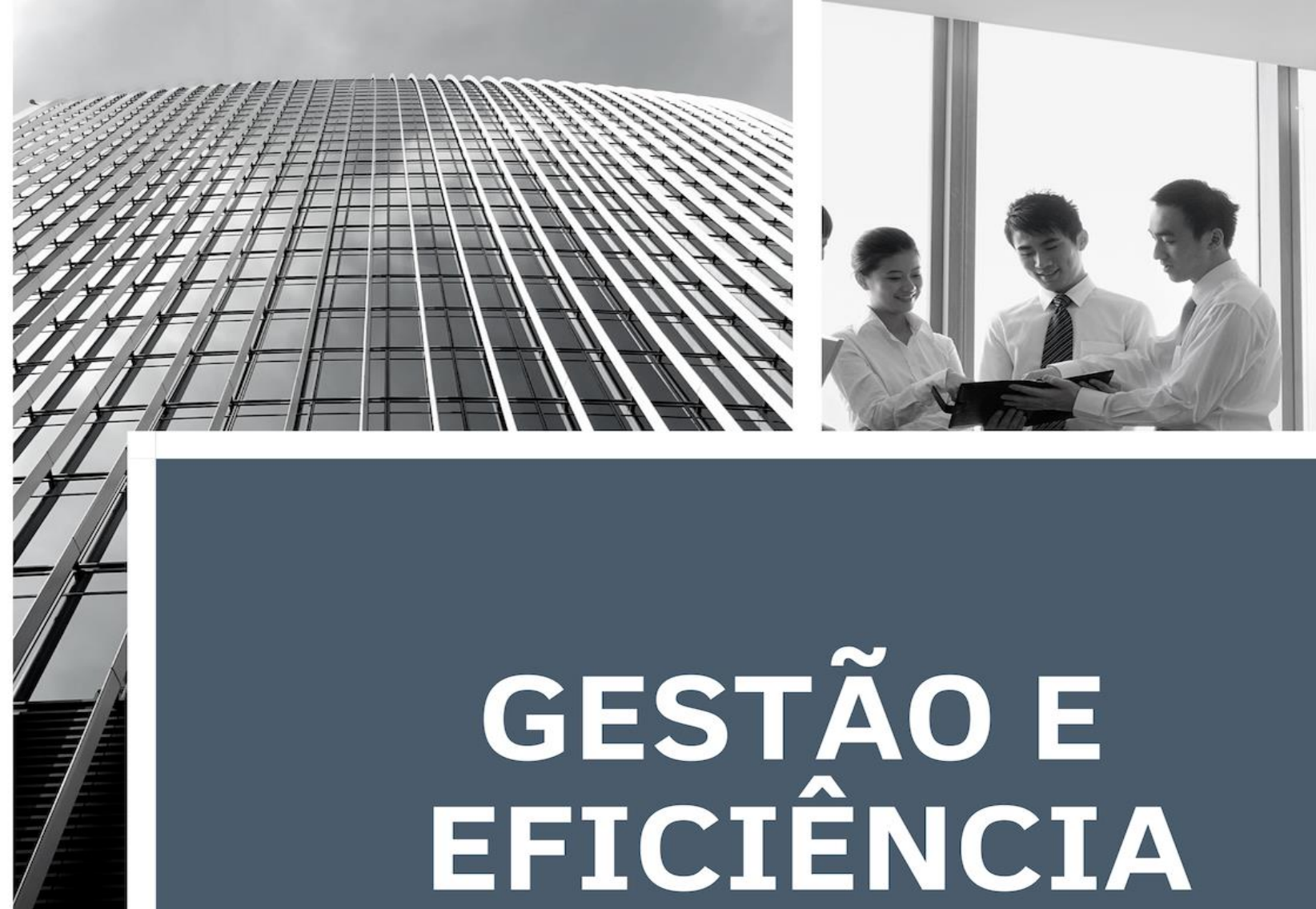

000009

V

ALVARO PRADO

AGUINALDO EDUARDO DE SOUZA

JULIO CESAR RAYMUNDO

ABELINO REIS GUIMARÃES NETO

(ORGANIZADORES)
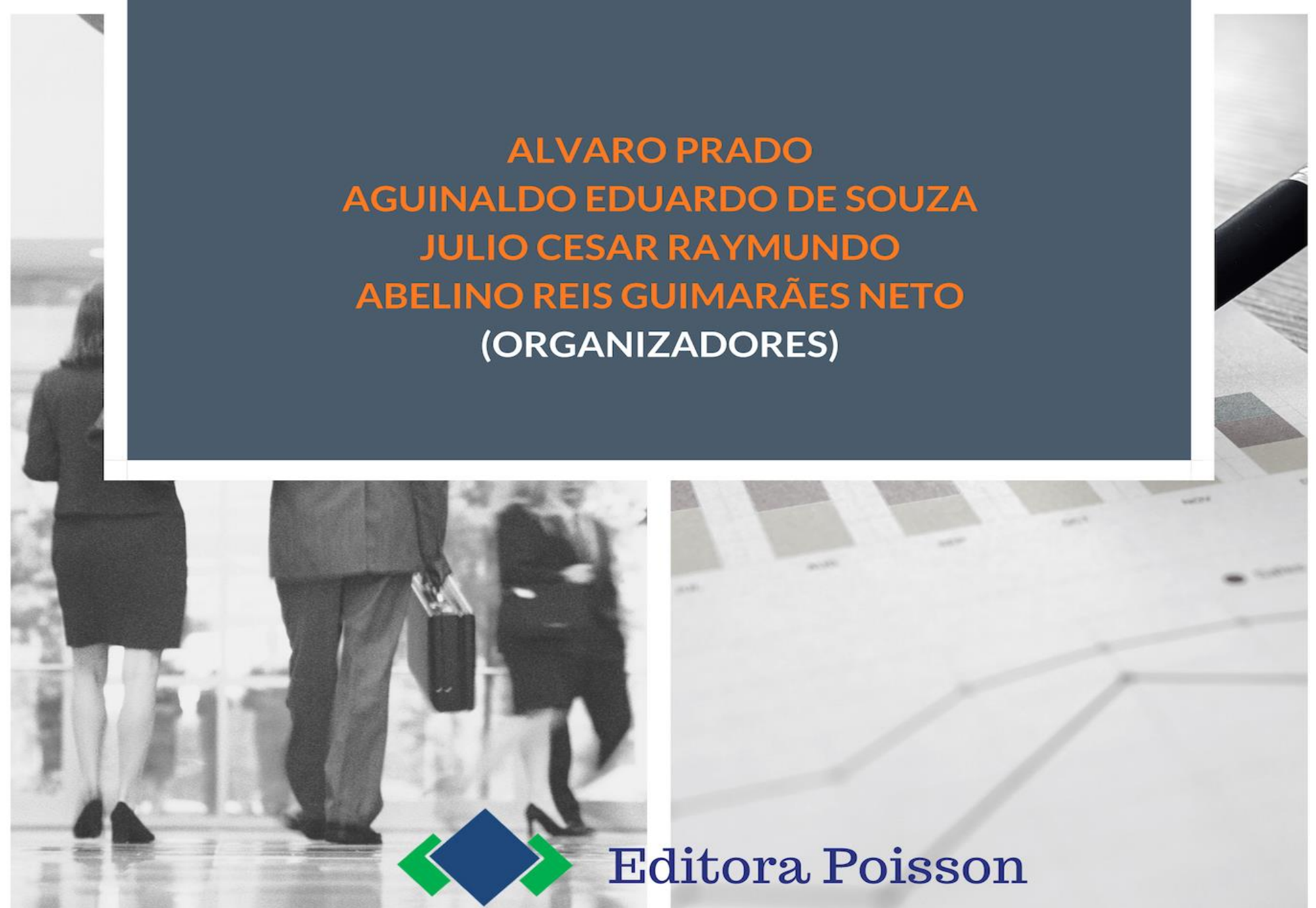

Editora Poisson 


\author{
Alvaro Prado \\ Aguinaldo Eduardo de Souza \\ Julio Cesar Raymundo \\ Abelino Reis Guimarães Neto \\ (Organizadores)
}

\title{
Gestão e Eficiência
}

\author{
$1^{\mathrm{a}}$ Edição
}

Belo Horizonte

Poisson

2019 
Editor Chefe: Dr. Darly Fernando Andrade

\section{Conselho Editorial}

Dr. Antônio Artur de Souza - Universidade Federal de Minas Gerais

Ms. Davilson Eduardo Andrade

Dr. José Eduardo Ferreira Lopes - Universidade Federal de Uberlândia

Dr. Otaviano Francisco Neves - Pontifícia Universidade Católica de Minas Gerais

Dr. Luiz Cláudio de Lima - Universidade FUMEC

Dr. Nelson Ferreira Filho - Faculdades Kennedy

Ms. Valdiney Alves de Oliveira - Universidade Federal de Uberlândia

Dados Internacionais de Catalogação na Publicação (CIP)

G393
Gestão e eficiência/ Organização: Alvaro
Prado, Aguinaldo Eduardo de Souza, Julio
Cesar Raymundo, Abelino Reis Guimarães
Neto - Belo Horizonte - MG: Poisson, 2019
194p
Formato: PDF
ISBN: 978-85-7042-050-3
DOI: 10.5935/978-85-7042-050-3
Modo de acesso: World Wide Web
Inclui bibliografia
1. Gestão 2. Logística. I. Título

O conteúdo dos artigos e seus dados em sua forma, correção e confiabilidade são de responsabilidade exclusiva dos seus respectivos autores.

Baixe outros títulos gratuitamente em www.poisson.com.br

contato@poisson.com.br 


\section{Prefácio}

A universidade é espaço de aprendizagem, de crescimento pessoal e profissional. Espaço no qual diferentes pessoas, com tão diversas formações e opiniões, se encontram para falar, ouvir, compartilhar. Mas este espaço não está limitado às paredes da sala de aula, ou dos laboratórios e auditórios. Muito pelo contrário. A universidade tem voz ativa na sociedade em que se encontra inserida. Essa verdade é nítida na Fatec Rubens Lara, instalada na cidade de Santos/SP. Professores e alunos se esforçaram para a produção deste livro. E seus temas necessitam ser divulgados e debatidos pela comunidade. Esse é o intuito desta obra.

O leitor poderá observar, ao longo da sua leitura, o quanto a inovação está presente em nossa realidade. Temas como carros elétricos, geoprocessamento, equipes de trabalho virtuais, compliance, e até mesmo a recente expansão mundial da produção de cervejas artesanais, são apresentados e discutidos em forma de estudos de casos. Nota-se que o empreendedorismo, perfil que nós, brasileiros, possuímos de forma latente, é um dos caminhos para o crescimento econômico e social deste país. Nossos professores e alunos notaram isso.

Mas para o empreendedor se tornar em um verdadeiro gestor, preparado para as rápidas e inesperadas mudanças em nossa sociedade, este deve ter uma base sólida de conhecimentos sobre alguns temas: governança corporativa, gestão de projetos, design thinking, política de formação de preços, atendimento ao cliente, previsão de demanda, armazenamento, ciclos operacionais e financeiros, etc. Todos estes temas estão abordados nesta obra, o que a torna em um compêndio de gestão empresarial.

Um assunto em destaque ao longo do livro é o tópico marketing, tão estudado e analisado pelos profissionais mais qualificados do mercado. Apresentado como ferramenta de gestão, o marketing também evolui ao longo do tempo, trazendo a ideia do CRM (ferramenta para gestão do relacionamento com o cliente) para empresas de diferentes portes. Assim como a gestão de pessoas é realçada nesta obra, trazendo para a nossa reflexão sua relevância enquanto função estratégica e idealizadora de uma melhor qualidade de vida no trabalho para todos os envolvidos.

Os organizadores, professores Alvaro Prado, Aguinaldo Eduardo de Souza, Julio Cesar Raymundo, Abelino Reis Guimarães Neto, edificaram um livro que pode ser facilmente utilizado tanto como guia de referência e consulta para os temas da gestão empresarial, como também enquanto ferramenta para docentes e alunos dos diversos cursos de graduação espalhados pelo Brasil, como administração de empresas, gestão empresarial, processos gerenciais, economia, e outros cursos correlatos, que poderão ler, refletir e discutir os ricos estudos de casos aqui expostos.

Você, caro leitor, aprecie esta obra e compartilhe de seu conteúdo com todos aqueles que estudam, e acreditam que a educação e a gestão empresarial podem ser verdadeiros caminhos para a tão necessária expansão intelectual que este país merece.

Boa leitura! 


\section{SUMÁRIO}

Capítulo 1: "Estado da arte" para a inovação: Da concepção da palavra aos mais recentes conceitos.....

Adriano Carlos Moraes Rosa, Fulvia Carolina Alves Correa, Katia Cristina Cota Mantovani, Vanessa Cristhina Gatto Chimendes, Yara Cristina Costa Rocha Miranda

Capítulo 2: A importância da governança corporativa e do compliance na mobilidade urbana em uma locadora de veículos 19

Alan Amorim de Jesus, Rita de Cassia Costa da Silva Holanda, Moacir de Freitas Junior

Capítulo 3: A iniciativa na gestão de projetos: Análise de um curso de extensão em escola profissionalizante 27

Renan Santos Destefani, Edilson Silva Araújo, Vanina Carrara Sigrist

Capítulo 4: A real situação dos carros elétricos e híbridos na região metropolitana do Vale do Paraíba e Litoral Norte 37

Natália Marcelino Ramos, Maurício Faria Nogueira, Antônio Wellington Sales Rios

Capítulo 5: Análise da influência da obrigatoriedade da rastreabilidade de medicamentos segundo a RDC 157/2017

Lucas Santana Freires, Jessicamaki Hirakawa Terra, Maick Roberto Lopes

Capítulo 6: Formação de engenheiros em cursos de graduação e pós-graduação no ensino a distância - Fundamentação do processo de "ouvir" do Design Thinking para a tutoria pedagógica em disciplinas de projetos. 54

Ricardo Venturineli, Júlio Cesar Ferreira dos Passos, Maria Juliana Góes Coelho da Cruz, Simone Seixas Picarelli

Capítulo 7: Inovação e empreendedorismo: Aprendendo e construindo gestão estratégica-organizacional em uma microempresa.

Isis Emanuelle Correia da Silva, Juliane dos Santos da Silva, Natan Gabriel de Paula Santos, Viviane Freire dos Santos, Pietra Monteiro de Oliveira Silva

Capítulo 8: Marketing para nichos de mercado: Ramo das cervejas artesanais no Brasil 70

Anderson Marques dos Santos, Luciano Gonçalves Costa, Isabel Cristina Mota 


\section{SUMÁRIO}

Capítulo 9: O uso da simulação para melhorias nos processos e atendimento ao cliente: Estudo de caso em uma pet shop. 79

Cristiane da Silva, Luciano Geraldo da Silva, Peri da Silva Santana

Capítulo 10: Previsão de demanda entre diferentes modelos aplicados a medicamentos do programa farmácia popular.... 89

Paulo André de Oliveira, Valquíria Ribeiro de Souza, Sérgio Augusto Rodrigues, Ricardo Ghantous Cervi

Capítulo 11: Processo de compartilhamento de conhecimento em equipes virtuais de trabalho no cenário brasileiro 97

Roberta de Oliveira Cabrera, Ieda Ribeiro, Marília Macorin de Azevedo, Napoleão Verardi Galegale, José Manoel Souza das Neves, Marcelo Duduchi Feitosa

Capítulo 12: Proposta para o armazenamento ideal de produtos alimentícios com especificidades de temperatura e umidade: Um estudo de caso em um redex no município de Cubatão 106

Clayton Gerber Mangini, Claudio Melin Doná, Julio Cesar Aparecido da Cruz, Wagner Delmo Abreu Croce

Capítulo 13: Qualidade de vida no trabalho (QVT) como diferencial na gestão estratégica de uma instituição federal de ensino: Análise dos documentos institucionais do IFAM 116

Wadna Kimberlly da Silva Alves, Henrique Menezes Nogueira, Geisy Anny Venâncio

Capítulo 14: Social CRM: Conceitos, aplicações e soluções 125

Adriano Carlos Moraes Rosa, Fulvia Carolina Alves Correa, Matheus Augusto de Lima Faria, Maycon Douglas do Nascimento Zangrandi

Capítulo15: Uso de ferramentas de geoprocessamento e análises geoestatísticas para evidenciar o status da atenção básica à saúde ofertada pelo município de Jacareí......

Deivid Márlon Fernandes da Costa, Vitor Luíz Monteiro Júnior, Sanzara Nhiaia Jardim Costa Hassmann

Capítulo 16: Tecnologia assistiva: Desenvolvimento de software para auxiliar na comunicação de crianças com o espectro autista 143

Lucas de Figueiredo José, Paulo Victor Homem de Mello Kusplica, Cristiane Marisa dos Santos, Alexandre Garcia de Oliveira 


\section{SUMÁRIO}

Capítulo 17: Estudos dos ciclos operacionais e financeiros do setor automobilístico

Patrícia Gonçalves Pinto, Sara Silva Duarte, Vinicius Carvalho Fernandes Assis, Lucineide Bispo dos Reis Luz

Capítulo 18: Análise dos impactos da implantação de faixa exclusiva para ônibus: Estudo de caso em uma via com fluxo contínuo de veículos 156

Erik Massahiro Sato, Fernando Mendes Torres, Luiz Antônio Tozi, Reinaldo Fagundes dos Santos

Capítulo 19: CRM - Ferramenta de gestão: relacionamento com o cliente na empresa fornecedora de gás GLP a granel.

Maristela de Freitas, Rafael Rolando Mitteenn Muñoz, Thais Masague Mizani, Keli Cristiane Vido

Capítulo 20: Gestão estratégica na formação do preço de serviço: Um estudo dos métodos utilizados 172

Mariana Martins de Mesquita, Vanusa Marisa Carvalho Magalhães Rocha, Jamile Brandão Silva Lucineide Bispo dos Reis Luz, Armindo Aparecido Evangelista

Autores: 180 


\section{Gapítulo 1}

\section{"ESTADO DA ARTE" PARA A INOVAÇÃO: DA CONCEPCÃO DA PALAVRA AOS MAIS RECENTES CONCEITOS}

\section{Adriano Carlos Moraes Rosa \\ Fulvia Carolina Alves Correa \\ Katia Cristina Cota Mantovani \\ Vanessa Cristhina Gatto Chimendes \\ Yara Cristina Costa Rocha Miranda}

Resumo: O estado da arte é ou estado do conhecimento é considerado o mais alto grau da evolução de um aparelho, uma técnica ou de uma área científica, alcançado em um tempo estabelecido. Quando comparado ao conhecimento acumulado de inovação, nos últimos anos, tem se produzido um conjunto significativo de pesquisas. Definidas como grandes contribuidoras pela multiplicação de conhecimento e atualização do termo, essas pesquisas trazem em comum o desafio de discutir e mapear essa prática hoje tão ascendente e responsável pela sobrevivência de empresas em diferentes segmentos que necessitam de apoio nos campos do conhecimento onde a inovação se estabelece. Tentam responder que aspectos e dimensões são destacados e privilegiados, desde que tempo suas práticas ganham projeção e quais desmembramentos são aproveitados por quais empresas e setores. Na tentativa de contribuir com um mapeamento de produções acadêmicas evidenciou-se que, além da apatia por conta dos gestores, a inovação ou a falta dela é edificada pelas particularidades e capacidades de inovação inerentes da empresa, pela diversidade dos colaboradores e demais interessados capacitados para a contribuição, pela forma de incentivo do raciocínio criativo e inovador, como cada segmento e departamento da empresa pode soma no processo da inovação e pela escassez de ideias ao se estabelecer objetivos e desafios inovadores aos colaboradores. Neste contexto, utilizando das metodologias de pesquisas exploratórias bibliográfica e documental, o presente artigo objetiva levantar algumas das mais importantes obras que respondem questões sobre a inovação.

Palavras-chave: Inovação 1. Pesquisa 2. Mapeamento 3. 


\section{INTRODUÇÃO}

Aveni (2014), credita ao economista francês Jean-Baptiste Say a responsabilidade de ser um dos primeiros expoentes a tratar de inovação, em seu estudo "A treatise on political economy: or the production, distribution and consumption of wealth", editado em 1803 (francês) e, novamente em 1821(inglês), ainda que, não utilizasse exatamente esse termo. Nessa época, eram considerados empreendedores ou inovadores os comerciantes, ou pessoas que faziam com que produtos circulassem, especialmente, pelas trocas. Já em um conceito atual, Trot (2012) define a inovação como a gestão de todas as atividades que abrangem um processo de concepção de ideias, desenvolvimento e aperfeiçoamento de tecnologias, fabricação e marketing de um produto novo ou de um processo de fabricação ou equipamento, um fator fundamental para crescimento econômico.

Assim, a inovação pode ser melhor explicada como uma ação de transformação de métodos clássicos de processos, conhecimentos, ou mesmo cultura em favor de decorrências para a construção do novo ou renovado método (LAMONT; MOLNAR, 2002, GALE, 2014), uma vez que, nos últimos anos, muita atenção é considerada para estes métodos nos contextos industriais e empresariais (SANTOS, FAZION, MEROE, 2011) neste trabalho, o ato de inovar passarse-á a representar também a necessidade de criação de estratégias, e com elas, sucesso e desenvolvimento.

A problemática que influenciou a pesquisa e a escrita desse artigo se baseou na premissa de que, no futuro só existirão dois tipos de empresas ou instituições, as inovadoras, que se dedicam, investem e se orientam às práticas da inovação e as mortas, dados os diversos exemplos de empresas que não inovaram e devastadas pelos concorrentes. A hipótese considerada pelos autores é que, diante de pesquisas e multiplicação de conhecimento sobre inovação, parte da história da formação da sociedade humana, pessoas empresas se interessarão pelo tema, o tomarão em suas bases como rotinas e guias, uma vez que, inovar significa facilitar caminhos, fazer algo de forma mais fácil e eficaz, desenvolver através do novo. Como moderador, o estudo pretende promover empresas "convencionais" não comprometidas com a inovação a empresas inovadoras, capazes de produzir inovações sistematicamente.

A pesquisa se justifica, pois, fortifica e oportuniza a promoção da inovação para vários setores, uma vez que, é necessário se pensar em possibilidades de mudanças para empresas e pessoas com problemas de carência de ideias para seus negócios, considerando que, são várias as áreas onde essas empresas e pessoas podem se reestruturar e, com a inovação "acelerada", realizar intervenções positivas proporcionando essas mudanças e, por consequência, retorno e equilíbrio financeiro. Aos autores, cabe também a justificativa de reciclagem de conceitos e práticas inerentes a inovação e possibilidade de multiplicação de conhecimento.

O objetivo geral dessa pesquisa consiste na elaboração de um documento que contenha princípios e diretrizes sobre o tema inovação que acorrerá tanto aos leigos quanto aos avançados interessados preocupados com a atualização dessa matéria. Em resumo, os objetivos específicos se desdobram em atualização das bases conceituais de inovação; elaboração um material que será utilizado em uma proposta assistencial aos profissionais e demais interessados sobre o tema; capacitação da escrita acadêmica ao documentar os textos relevantes e resultados da pesquisa; oportunidade de multiplicação na comunidade acadêmica.

A metodologia adequada escolhida se deu pela pesquisa exploratória bibliográfica e documental. Segundo Malhotra (2001), as pesquisas podem ser classificadas, em termos amplos de objetivos, como conclusivas ou exploratórias, e esta ainda pode ser dividida em causal ou descritiva, como neste artigo. A pesquisa também se baseou em coleta e análise de obras literárias que, segundo Fachin (2006), denomina-se pesquisa bibliográfica, utilizada por compreender todo um levantamento das obras escritas, bem como a matéria constituída por dados primários ou secundários que venham a ser utilizados por um pesquisador. Já de acordo com Pádua (2007) a pesquisa também é documental, realizada a partir de documentos científicos autenticos que possibilitam a comparação ou a descrição de fatos, estabelecendo características ou tendências. 


\section{REFERENCIAL TEÓRICO}

Neste artigo se trabalhou como base teórica a origem histórica e a evolução dos conceitos de inovação e, mostrou-se de forma resumida a tipologia da inovação e, uma breve explanação sobre o processo da inovação.

\subsection{HISTÓRIA: DA ORIGEM HISTÓRICA ATÉ A ERA DO CONHECIMENTO.}

A palavra inovação é um vocábulo latino proveniente de innovare que significa fazer algo novo, tornar possibilidades em novas ideias reais, colocando estas em prática (FREEMAN; SOETE, 1997; ZANELLA, et al., 2012). Historicamente, a inovação pode ser dividida em fases, sendo a primeira fase, a da invenção, presente desde o início da humanidade, a segunda da imitação ou difusão, comum nos mercados cuja economia globalizada foi alicerçada pela produção e terceirização de produtos de consumo e, ainda, uma terceira fase, oriunda da estratégia para sustentabilidade econômica das organizações, motivada pelo conhecimento emergente após globalização da economia e alternativa para acompanhar a velocidade de demanda por novos produtos (SANTOS; FAZION; MEROE, 2011; FERREIRA; PUGAS; DA SILVA, 2016).

A história da inovação se origina também na busca do ser humano pela sobrevivência e, acredita-se que em Olduvai, Tanzânia, continente Africano, seja o local onde os teóricos entendem ter surgido os mais remotos antepassados da raça, uma vez que lá, foram encontrados registros de inovação com o desenvolvimento de artefatos de apoio na busca por comida, principal desafio da época (COSTA, 2009; ROBERTS, 2001; LÓPEZ, 2015). A partir do reconhecimento de que 0 desenvolvimento depende da capacidade de inovação de uma sociedade, outras constatações podem ser feitas: a capacidade de inovação está ligada a vários atores como governo, instituições provedoras de conhecimento científico e tecnológico e; os processos de crescimento estão enraizados no território e são dotados de história, ou seja, o ambiente inovador interagirá no meio local de uma cultura e de atores que ali estão (ALBAGLI, 2006; CHIARINI; VIEIRA, 2012; ALMEIDA; DA SILVA; ROCHA, 2013).

Para a segunda etapa, tendente para a difusão e multiplicação dos mercados e economia respaldada pela produção e terceirização, muitos estudos a investigaram, e procuraram definir e compreender seus processos inovativos que, por muito tempo, foram entendidos como a alicerces da economia competitiva. Esses estudos evidenciaram $O$ sucesso empresarial competitivo dependente dessa influente gestão da inovação, que ainda, propuseram vários fatores que poderiam estar alinhados a esses promitentes processos (HAMEL, 2006; ROSSETTI; MORALES, 2007; DI BENEDETTO, 2012).

Outros autores também declaram a inovação como uma questão de subsistência, pois, as infrequências tecnológicas provocam velozes e significativas mudanças no composto socioeconômico e cultural, mudanças que inflamam o desejo pelo novo, a necessidade das organizações de inovarem e sempre se reinventarem, assim, quem não estiver adaptado a esse novo cenário deve se preparar, então, para um desfecho gradativo ou imediato (RODRIGUEZ Y RODRIGGUEZ, 2005; BESSANT, 2008; SAVITSKAYA; SALMI; TORKKELI, 2010).

Em relação a criatividade na era do conhecimento, a inovação é "sim" um meio criativo de aproveitamento de um conhecimento existente, que possa combinar pequenos fragmentos de outros conhecimentos para criar uma nova habilidade ou novas soluções e, dessa forma, esse processo envolve todo um ciclo que compreende pesquisa básica, aplicada, desenvolvimento, produção, e todas as interações e realimentações possíveis entre as fases (CALDAS, 2001; CARVALHO, SUGANO, AGUIAR, 2016). Uma base conceitual concernente à inovação muito bem trabalhada é creditada a Silva e Dacorso (2013) como mostra o Quadro 1: 
Quadro 1: Evolução dos Conceitos de Inovação

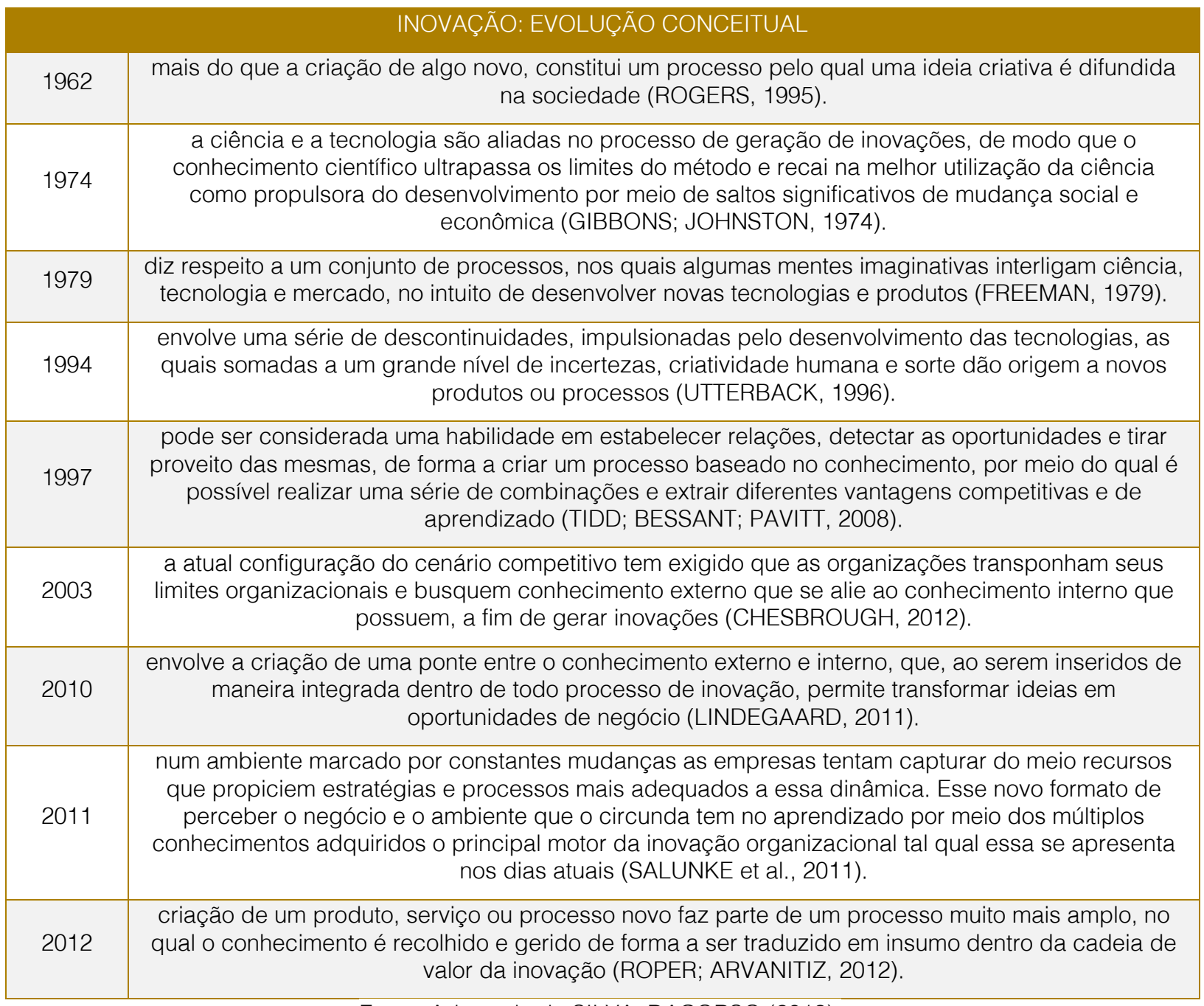

Fonte: Adaptado de SILVA; DACORSO (2013).

\subsection{TIPOLOGIA DA INOVAÇÃO}

Segundo Schumpeter (1997), mesmo que economia se encontre equilibrada em relação aos fluxos de capitais, a atividade empreendedora e a inovação podem alterar esse equilíbrio criando monopólios temporários e gerar riqueza. Nesses pontos de desequilíbrio, a introdução de inovações drásticas ou radicais planta sementes de destruição da ordem econômica vigente, promovendo a "destruição criativa".

A Figura 1 exemplifica o processo na indústria da música:

Figura 1: Processo de Destruição Criativa Segundo Schumpeter

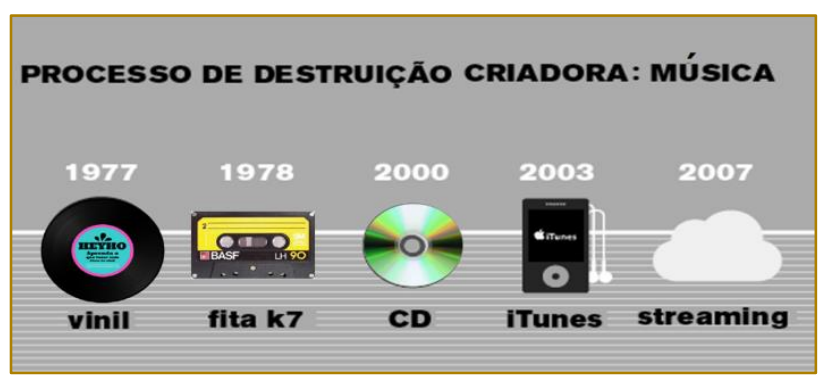

Fonte: Adaptado de DC (2014) 
Para a OCDE e FINEP (2004) na elaboração do Manual de Oslo, concentram-se em quatro tipos principais de inovação: inovação de produto, inovação do processo, inovação de marketing e inovação organizacional (Figura 2):

Figura 2: Tipologia da Inovação Segundo o Manual de Oslo

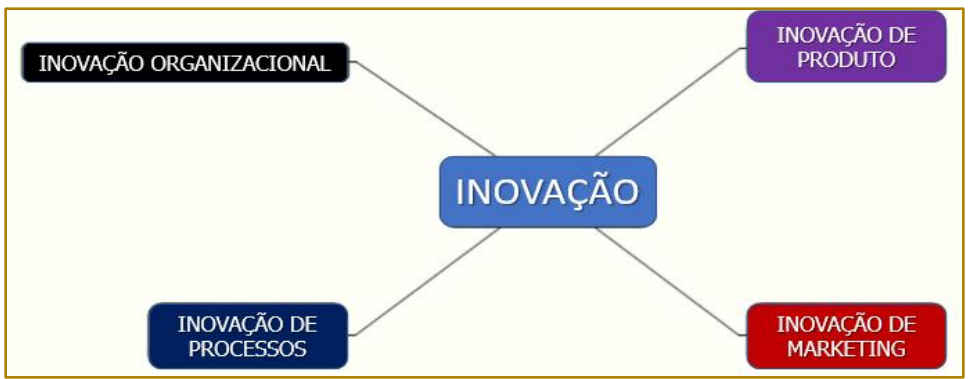

Fonte: Adaptado de Manual de Oslo (OCDE FINEP, 2004)

Segundo Tidd, Bessant e Pavit, (2008), a inovação se concentra em um espaço desenvolvido diante de 4 P's ou, inovação em produto: mudanças nos resultados que uma empresa oferece; inovação de processos: mudanças na forma em que os produtos ou serviços são criados e entregues; inovação da posição: mudanças no contexto em que produtos e serviços são introduzidos; inovação de paradigma ou modelo mental: mudanças nos modelos mentais implícitos que orientam o que a empresa faz. A Figura 3 ilustra os termos:

Figura 3: O Espaço da Inovação

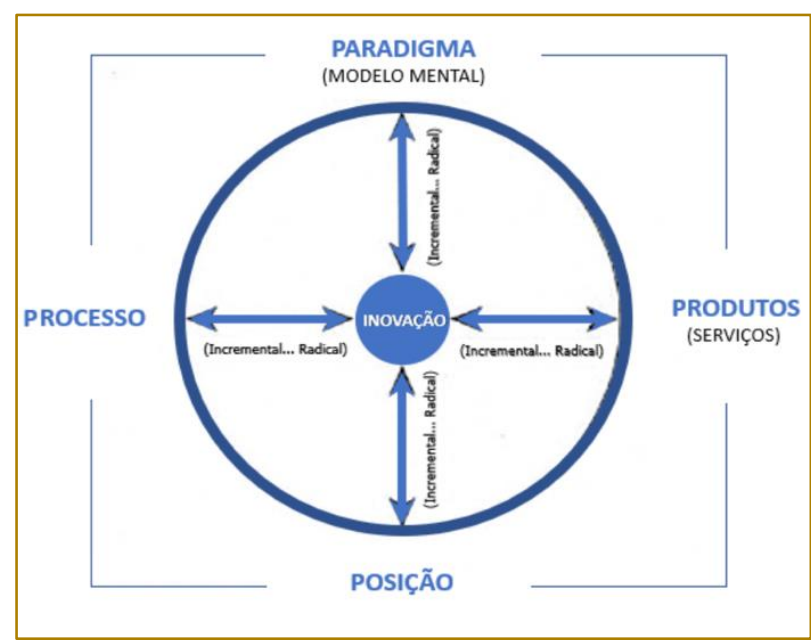

Fonte: Adaptado de Tidd, Bessant e Pavit, (2008)

Com relação a importância dos tipos de inovação, existem ainda diferentes maneiras de classificação que podem ser tratadas quanto ao grau de impacto (incremental e radical). Freeman e Soete (1997) e, posteriormente, Tigre (2014) detalham essa tipologia considerada "clássica" paras as inovações focadas em mudanças tecnológicas, diferenciadas por seu grau de inovação e pela extensão das mudanças em relação ao que existia antes. Essas inovações na atividade econômica são classificadas segundo seus impactos como mostra o Quadro 2: 
Quadro 2: Mudanças na Atividade Econômica e Tecnológicas

\begin{tabular}{|c|c|}
\hline TIPO DE MUDANÇA & CARACTERÍTICAS \\
\hline Incremental & Melhoramentos e modificações cotidianas. \\
\hline Radical & Saltos descontínuos na tecnologia de produtos e processos. \\
\hline Novo Sistema Tecnológico & $\begin{array}{c}\text { Mudanças abrangentes que afetam mais de um setor e dão origem a novas } \\
\text { atividades econômicas. }\end{array}$ \\
\hline $\begin{array}{l}\text { Novo Paradigma } \\
\text { Tecnoeconômico }\end{array}$ & $\begin{array}{l}\text { Mudanças que afetam toda a economia envolvendo mudanças técnicas e } \\
\text { organizacionais alterando produtos e processos, criando industrias e } \\
\text { estabelecendo trajetórias de inovações por várias décadas. }\end{array}$ \\
\hline
\end{tabular}

Fonte: Adaptado de Freeman e Soete (1997) e Tigre (2014).

Concordantes com a leitura anterior, Henderson e Clark (1990) propuseram uma tipologia de inovação baseada na arquitetura de produtos dividida em:

Inovação incremental: melhorias apenas no nível de componente, deixando a arquitetura inalterada. Refina e amplia um design estabelecido. A melhoria ocorre em componentes individuais, mas os conceitos fundamentais de design básico e os links entre eles permanecem os mesmos; Inovação radical: estabelece um novo projeto dominante e, portanto, um novo conjunto de conceitos de design básico incorporados em componentes que estão ligados entre si em uma nova arquitetura; Inovação modular: muda apenas os principais conceitos de design de tecnologia e inovação que alteram apenas as relações entre eles, como a substituição de aparelhos analógicos por telefones digitais. Na medida em que se pode simplesmente substituir um dispositivo de discagem analógica por um digital, é uma inovação que muda um conceito de design básico sem alterar a arquitetura do produto; Inovação arquitetônica: altera a arquitetura de um produto, mas deixa os componentes e os conceitos básicos de design que eles incorporam inalterados. (HENDERSON; CLARK, 1990, p.12).

A Figura 4 exemplifica a tipologia:

Figura 4: Tipologia da Inovação Baseada na Arquitetura de Produtos

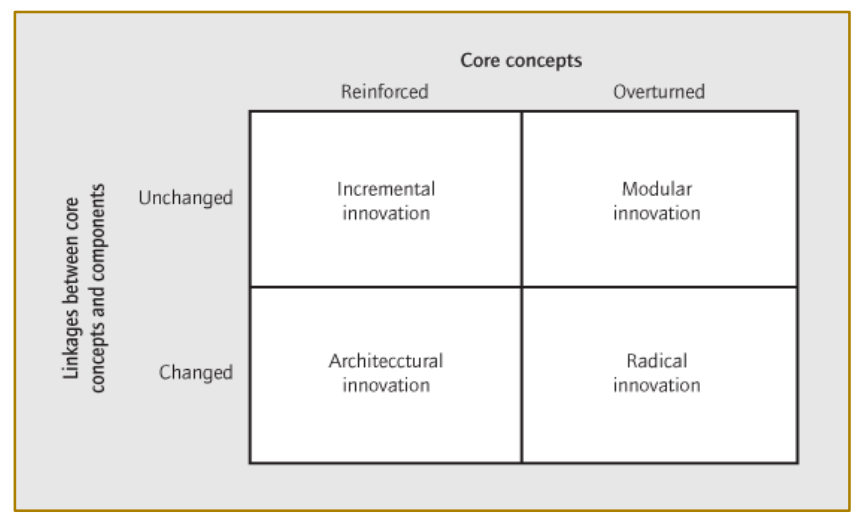

Fonte: Adaptado de Henderson e Clark (1990)

Christensen (1997) multiplicador das inovações do tipo disruptivas, consegue difundir o termo "inovação disruptiva", reconhecendo que poucas tecnologias são disruptivas de fato ou sustentáveis, uma vez que, é a estratégia ou modelo de negócios que a tecnologia aciona que cria o impacto disruptivo. Alguns de seus princípios básicos são que: a satisfação cria condições para a disrupção; a disrupção é resultado da quebra de regras; e que a inovação do modelo de negócios normalmente impulsiona a disrupção. Adota para as novas tecnologias os termos: inovação sustentadora, aquela que resulta em produtos e serviços que atendem à demanda de clientes existentes em mercados estabelecidos e, inovação disruptiva, que resulta na criação de novos mercados e 
Figura 5: Tipologia da Inovação Disruptiva

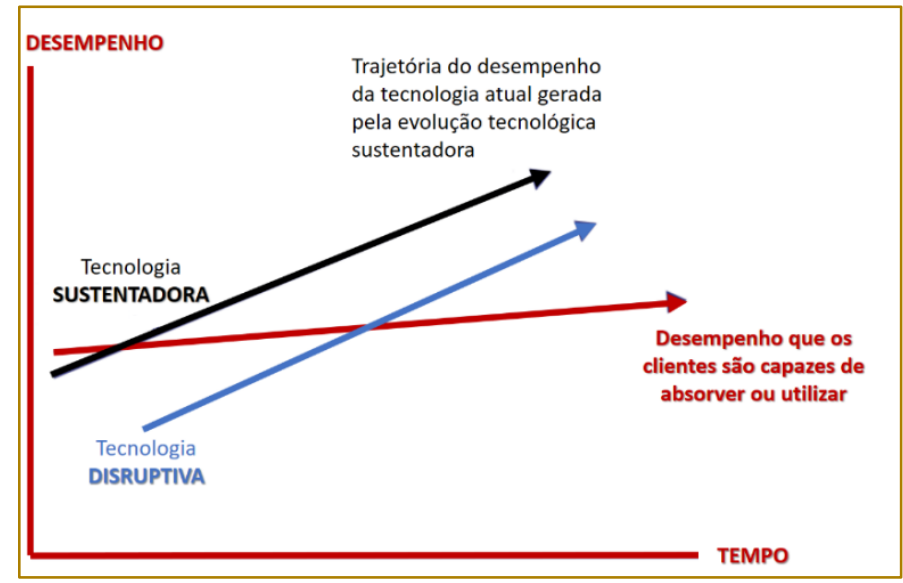

Fonte: Adaptado de Christensen (1997)

Para Gundling (2000), pelo grau de novidade, a empresa gera três tipos de inovação, a considerar:

Tipo A: inovação que gera um novo negócio, transcendendo os desejos presentes dos consumidores e criando necessidades que ainda não haviam sido articuladas (abrasivos pastosos e ou revestidos e fita adesiva); Tipo B: inovações que mudam as bases da competição, criando uma nova posição competitiva ou nicho dentro de um campo estabelecido ou uma inovação originada em pesquisas de laboratório, sem ter exatamente uma identificação prévia de demanda para necessidades dos consumidores; Tipo C: inovação que produzem avanço incremental como em blocos de papel com adesivo em vários formatos e cores, prolongando a vida do produto que, nesse caso, ela está associada ao atendimento explícito de necessidades dos consumidores. (GUNDLING, 2000, p. 58).

Bachmann e Destefani (2008) descrevem o conceito de Zonas de Inovação que dividem as ações inovativas em 3 tipos sendo:

Inovação Básica: pequenas melhorias no produto ou serviço, baseadas em extensão das linhas ou melhorias incrementais. Exemplos: Coca-Cola com limão; Inovação Relativa: inovações que se baseiam em produtos/serviços existentes, voltados para novos mercados. Exemplo: Gillette Sensor (para mulheres); Inovação Conceitual: produtos ou serviços com novo conceito, propostas de valor e modelos de negócio revolucionários. Exemplos: EasyJet. (BACHMANN; DESTEFANI, 2008, p.6).

\subsection{BREVE EXPLANAÇÃO SOBRE PROCESSO DA INOVAÇÃO}

São vários os trabalhos e pesquisas que mostram o processo da inovação envolvendo a criação, o desenvolvimento, o uso e a difusão de um novo produto ou ideia, ou resumidamente, a introdução e difusão de produtos e processos novos e melhorados.

Utterback (1983), por exemplo, estudando a inovação e a sobrevivência das empresas também demonstrou as fases para este processo:

Experimentação: fase inicial ou crescimento onde o número de empresas em determinado setor disputa por inovações relevantes; Inovação: fase de elaboração de ideias e projetos onde permite-se um número máximo de participantes que realmente desenvolvem os projetos da fase anterior, ou seja, desenvolvem inovação passando parta a fase seguinte; Dominação: fase onde ocorre um aprendizado e amadurecimento do conseguido nas fases anteriores e, por consequência, o domínio de mercado, que a partir do qual, começa a decrescer; Estabilização: fase onde restará um número pequeno de empresas. (UTTERBACK, 1983, p. 39).

A Figura 7 explicita essas fases: 
Figura 7: Processo de Inovação e a Sobrevivência das Empresas

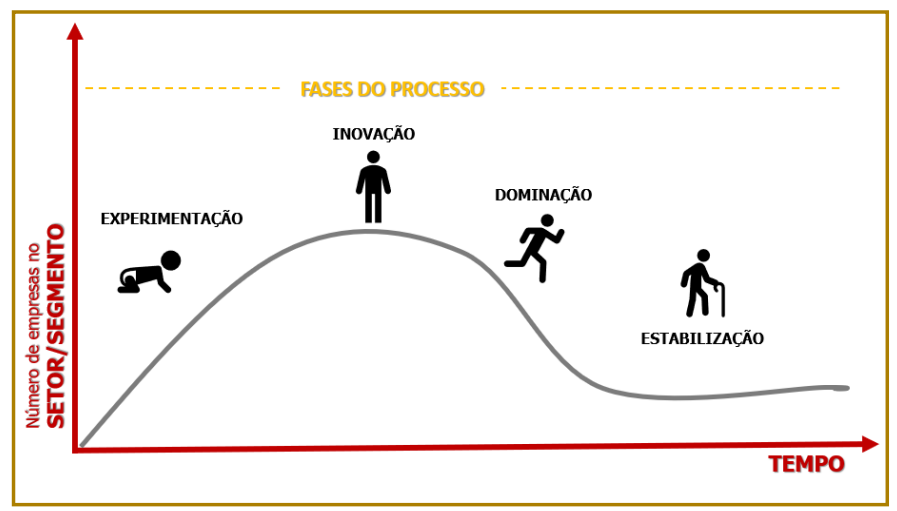

Fonte: Adaptado de Utterback (1983).

Já para Van de Ven (1986), a inovação é um processo sociopolítico que precisa de um líder que seja capaz de tomar a iniciativa e conduzir a empreitada até sua implementação. Relaciona a esse processo de inovação quatro problemas:

Aproximação das pessoas para a nova ideia: as estruturas organizacionais muitas vezes levam as pessoas a focar a rotina ao invés de novas ideias e processos, o que pode gerar insensibilidade às mudanças no ambiente;

Transformação da nova ideia em realidade: muitas ideias são propostas, mas somente algumas são conduzidas até a implementação por limitações do processo político-organizacional e limitações humanas para lidar com complexidade e novas ideias;

Coordenação da integração entre as partes: enquanto a geração da ideia pode ser individual, o processo de inovação é geralmente coletivo, o que traz para a cena múltiplos atores com diferentes ideias, visões e percepções, o que gera uma proliferação de relacionamentos e transações entre as partes envolvidas;

Condução institucional: desenvolvimento, na organização, de uma cultura que permita a coexistência de processos institucionais e técnicos de forma a criar um ambiente propício para a condução da ideia até a implementação (VAN DE VEM,1986, p. 598).

\section{RESULTADOS E DISCUSSÃO}

Em decorrência do conteúdo apresentado nas seções anteriores deste artigo, pode-se como resultado, reiterar que o espaço envolto à inovação é hoje um espaço comunitário que, através de relações sociais, possibilitase o empoderamento e construção de conhecimento. Isso indica que, quem mais ativamente entende, aceite, e aplique seus princípios tende a ter um maior e mais rápido sucesso. É possível afirmar também, que com as novas vertentes estudadas, algumas ênfases sobre o assunto, atualmente são mais e menos abordadas em pesquisa. Isso condiciona os autores a entenderem e recomendarem como vertentes ou foco dos trabalhos consolidados recentemente sobre inovação (em resumo) algumas das 10 expressões ou palavras ligadas ao termo. Nesse contexto, as palavras mais encontradas foram: Clareza; Estrutura; Foco no cliente; Ideia; Informação; Mudança; Oportunidade; Recurso; Relação externa; Tangibilidade. Com isso, no intuito de apresentar também alguns resultados de trabalhos exemplificando essas melhores e mais atualizadas vertentes e seus proeminentes autores, para este artigo, utilizando o material adquirido e catalogado, elaborou-se o Quadro 2: 
Quadro 2: Atualização da Evolução dos Conceitos e Ênfases da Inovação

\begin{tabular}{|c|c|c|}
\hline ENNFASE & INOVAÇÃO É. & AUTORES \\
\hline $\begin{array}{l}\text { MUDANÇA; } \\
\text { MELHORIA }\end{array}$ & $\begin{array}{l}\text { Introdução de qualquer tipo de mudança ou melhoria } \\
\text { realizada em um produto, processo ou tipo de } \\
\text { organização da produção dentro da empresa e, pode- } \\
\text { se referir, ainda, a alterações de tal ordem, que geram } \\
\text { um novo produto, processo ou forma de organização } \\
\text { da produção. }\end{array}$ & $\begin{array}{c}\text { GALÃO; CAMARA, (2006) } \\
\text { BESSANT (2008) }\end{array}$ \\
\hline $\begin{array}{l}\text { MELHOR } \\
\text { RECURSO; } \\
\text { MUDANÇA } \\
\text { ESTRUTURAL }\end{array}$ & $\begin{array}{l}\text { Atribuição de novas capacidades aos recursos como } \\
\text { processos e pessoas, elementos existentes na } \\
\text { empresa para gerar riqueza, impulsionar o sucesso } \\
\text { competitivo das empresas não somente com a criação } \\
\text { de novos produtos, mas também, através de } \\
\text { mudanças na sua estrutura. }\end{array}$ & $\begin{array}{l}\text { CHIBÁS; PANTALEÓN; } \\
\text { ROCHA, (2013) }\end{array}$ \\
\hline $\begin{array}{l}\text { MELHORES } \\
\text { RELAÇÕES } \\
\text { EXTERNAS }\end{array}$ & $\begin{array}{l}\text { Implementação de um produto (bem ou serviço) novo } \\
\text { ou significativamente melhorado, ou um processo, ou } \\
\text { um novo método de marketing ou um novo método } \\
\text { organizacional nas práticas de negócios, na } \\
\text { organização do local de trabalho ou nas relações } \\
\text { externas. }\end{array}$ & OCDE; FINEP (2004) \\
\hline $\begin{array}{l}\text { OPORTUNIDADES; } \\
\text { FOCO NO } \\
\text { CLIENTE. }\end{array}$ & $\begin{array}{l}\text { Ajustamento, reprodução, experimentação, design, } \\
\text { desenvolvimento e pesquisa, até mesmo a forma de } \\
\text { buscar novidades pode ser inovadora como, por } \\
\text { exemplo, a busca por oportunidades para a inovação } \\
\text { conceitual tem sido feita pelo deslocamento do foco } \\
\text { no cliente para foco na circunstância ou no ambiente } \\
\text { de uso dos produtos, buscando soluções para os } \\
\text { problemas e dificuldades dos clientes. }\end{array}$ & $\begin{array}{c}\text { BACHMANN; DESTEFANI } \\
(2008) \\
\text { COSTA (2009) }\end{array}$ \\
\hline $\begin{array}{l}\text { TANGIBILIDADE; } \\
\text { CLAREZA NAS } \\
\text { AÇÕES; } \\
\text { NOVIDADE. }\end{array}$ & $\begin{array}{l}\text { Concretização de uma ideia clara ou a possibilidade } \\
\text { de aplicação do "novo" no mercado ou num processo } \\
\text { de produção e, em uma abordagem mercadológica } \\
\text { para diferentes classes de utilizadores, é uma criação } \\
\text { original. }\end{array}$ & DE PAULA (2014) \\
\hline $\begin{array}{l}\text { MELHOR } \\
\text { QUALIDADE; } \\
\text { TROCA DE } \\
\text { INFORMAÇÕES }\end{array}$ & $\begin{array}{l}\text { Algo que pode melhorar a qualidade e eficiência do } \\
\text { trabalho, acentuar a troca de informações e refinar a } \\
\text { capacidade empresarial de aprender e utilizar } \\
\text { conhecimentos e tecnologias, já que nos últimos anos, } \\
\text { essa inovação se estabelece como fator importante } \\
\text { para a garantia do crescimento, competitividade e } \\
\text { rentabilidade das empresas. }\end{array}$ & $\begin{array}{c}\text { FREIRE; FREIRE (2010) } \\
\text { CARVALHO; SUGANO (2016) }\end{array}$ \\
\hline $\begin{array}{l}\text { GERAÇÃO DE } \\
\text { IDEIAS }\end{array}$ & $\begin{array}{l}\text { É a prática agregada à gestão de atividades do } \\
\text { processo de geração de ideias e de tecnologias, } \\
\text { fabricação e marketing para novos ou } \\
\text { aperfeiçoados produtos, ou mesmo de um } \\
\text { processo de fabricação ou equipamento. }\end{array}$ & $\begin{array}{c}\text { PLONSKI (2005) } \\
\text { SANTOS; FAZION; MEROE } \\
(2011)\end{array}$ \\
\hline
\end{tabular}

Fonte: Elaborado pelos Autores.

\section{CONSIDERAÇÕES FINAIS}

Entendendo que a inovação e suas práticas protagonizam um cenário hoje onde várias atividades são consideradas como "chave" na geração de vantagens competitivas a curto, médio ou longo prazo, conclui-se que estudar a inovação é mesmo essencial para o desenvolvimento sustentável e para o equilíbrio financeiro das empresas, assim como, para a geração de conhecimento e tecnologias para a sociedade.

Com o artigo foi possível estudar essas principais bases conceituais de inovação e elaborar uma verdadeira triagem de material, uma vez que, com o crescimento do respeito e relevância do tema, muitos livros e artigos são produzido dentro e fora do Brasil, assim, o resultado parcial dessa pesquisa (gerador 
desse artigo) certamente será disponibilizado em mídias impressas e eletrônicas para que possa ser utilizado como recurso assistencial aos interessados sendo estes profissionais ou não.

Mesmo que parcialmente, também seja reconhecida a importância da prática da escrita acadêmica, ao documentar textos e resultados neste artigo, ação esta, pensada justamente para o aproveitamento da oportunidade de multiplicação do mesmo na

\section{REFERÊNCIAS}

[1]. ALBAGLI, S. Conhecimento, inclusão social e desenvolvimento local. Revista IBICT Inclusão Social, vol.1, n. 2, p. 17-22, 2006.

[2]. ALMEIDA, A.; DA SILVA, B.; ROCHA, C. A Influência dos Parques Tecnológicos nos Cursos da Área de TI e no Desenvolvimento Econômico. Revista Cientifica On-Line Tecnologia, Gestão e Humanismo. vol. 2, n. 1, 2013.

[3]. AVENI, A. Empreendedorismo Contemporâneo: teorias e tipologias. São Paulo: Atlas, 2014

[4]. BACHMANN, D. ; DESTEFANI, J. Metodologia para Estimar o Grau de Inovação nas MPE: cultura do empreendedorismo e inovação. XVIII Seminário Nacional de Parques Tecnológicos e Incubadoras de Empresas. Curitiba (PR): SEBRAE, 2008

[5]. BESSANT, J. Managing Innovation: meeting the 21st century challenge. Tanaka Business School, Imperial College, London and Advanced Institute of Management Research, UK, 2008.

[6]. CALDAS, R. Construção de Modelo de Arcabouço Legal para Ciência, Tecnologia e Inovação. Parcerias Estratégicas, Brasília (DF), vol.6, n.11, p.5-27, 2001.

[7]. CARVALHO, E.; SUGANO, J. Entrepreneurial Orientation and Open Innovation in brazilian Startups: a multicase study. Interações, vol. 17, n. 3, p. 448-462, 2016.

[8]. CHIARINI, T.; VIEIRA, K. Universidades como Produtoras de Conhecimento para o Desenvolvimento Econômico: Sistema Superior de Ensino e as Políticas de CT\&I. Revista Brasileira de Economia. Rio de Janeiro, vol. 66 n. 1, p. 117-132, 2012.

[9]. CHIBÁS, F.; PANTALEÓN, E.; ROCHA, T. Gestão da Inovação e da Criatividade Hoje: apontes e reflexões. Revista Holos, Ano 29, vol. 3, p.15-26, 2013.

[10]. CHRISTENSEN, C. The Innovator's Dilemma: When New Technologies Cause Great comunidade acadêmica com a participação dos autores em congressos e revistas, foi percebida a evolução do termo e práticas (como descrito na discussão).

Como o objetivo principal dessa pesquisa foi compor uma seleção de princípios e diretrizes sob a temática de inovação que proporcionasse aos interessados atualização e direcionamento, os autores, com este resultado, acreditam que tal objetivo foi cumprido.

Firms to Fail. Harvard Business School Press: Cambridge, MA, 1997.

[11]. COSTA, O. Sobre as causas evolutivas da cognição humana. Dissertação (Mestrado em Filosofia) Faculdade de Filosofia e Ciências, Universidade Estadual Paulista, Marília (SP), 2009.

[12]. DC. Destruição Criadora Reinventa Modelos e Mercados, 2014. Redação DC. Diário do Comércio.

[13]. DE PAULA, C. Análise do Grau de Inovação das Micro e Pequenas Empresas do Segmento Alimentício Atendidas pelo Programa Agentes Locais de Inovação na Região Oeste do Estado de Goiás. 2014. Dissertação (Mestrado em Administração) Faculdade Alves Faria, Goias (GO), 2014.

[14]. DI BENEDETTO, C. The JPIM thought leadership symposium. Journal of Product Innovation Management, vol. 29, n. 3, p. 344-348, 2012.

[15]. FACHIN, O. Fundamentos de Metodologia. 5a. Ed. São Paulo (SP): Saraiva, 2006.

[16]. FERREIRA, H.; PUGAS, M. ; DASILVA, N. Maturidade Organizacional: uma visão dos impactos gerenciais nos processos de inovação organizacional sob a ótica do modelo de ciclo de vida de Adizes. XIX SEMEAD, FEA/USP, nov, 2016.

[17]. FREEMAN, C.; SOETE, L. The Economics of Industrial Innovation. 3‥ Ed. Routledge, Abingdon, Oxon UK, 1997.

[18]. FREIRE, R.; FREIRE, R. Gestão do Conhecimento e Inovação: uma questão estratégica na administração por processos. SMI: Belo Horizonte (MG), 2010.

[19]. GALÃO, F.; CAMARA, M. Inovação e orientação para o mercado no APL do vestuário de Londrina. XIII SIMPEP Simpósio de Engenharia de Produção. Bauru (SP), Brasil, 06 a 08 de novembro, 2006. 
[20]. GALE, N. The Sociology of Traditional, Complementary and Alternative Management. Social Compass. vol. 8, n.6, p. 805-822, 2014.

[21]. GUNDLING, E. The 3M Way to Innovation: balancing people and profit. Tokyo: Kodansha, 2000.

[22]. HAMEL, G. The why, what, and how of management innovation. Harvard Business Review. vol.84, n. 2, p.72-84, 163, 2006

[23]. HENDERSON, R. M.; CLARK, K.B. Architectural Innovation: The Reconfiguration Of Existing Product Technologies and the Failure of Established Firms. Administrative Science Quarterly, vol.35, n.1, p. 9-30, 1990.

[24]. LAMONT, M.; MOLNAR, V. The Study of Boundaries in the Social Sciences. Annual Reviews, vol. 28, p. 167-195, 2002.

[25]. LÓPEZ, A. Um Antepassado de Sete Milhões de Anos. Organização Internacional Nova Acrópole, Bruxelas. Bélgica. Revista Esfinge. fev, 2015.

[26]. MALHOTRA, N. Pesquisa de Marketing: uma orientação aplicada. Porto Alegre: Bookman, 2001.

[27]. OCDE-FINEP. Organização para Cooperação Econômica e Desenvolvimento. Manual de Oslo: Diretrizes para Coleta e Interpretação de Dados sobre Inovação. 3ạ. Ed. OCDE. FINEP, 2004.

[28]. PÁDUA, E. Metodologia da Pesquisa: abordagem teórico-prática. Campinas (SP): Papirus, 2007.

[29]. PLONSKI, G. Bases para um Movimento pela Inovação Tecnológica no Brasil. São Paulo em Perspectiva. vol.19 n.1, 2005.

[30]. ROBERTS, J. Livro de Ouro da História do Mundo: da pré-história a idade contemporânea. 5‥ Ed. São Paulo: Ediouro Publicações, 2001.

[31]. RODRIGUEZ Y RODRIGUEZ, M. O Valor da Inovação. Harvard Business Review. Rio de Janeiro: Campus/Elsevier, 2005.
[32]. ROSSETTI, A.; MORALES, A. O Papel da Tecnologia da Informação na Gestão do Conhecimento. Instituto Brasileiro de Informação em Ciência e Tecnologia. Revista Ciência da Informação, vol. 36, n. 1, p. 124-135, 2007.

[33]. SANTOS, A.; FAZION, C.; MEROE, G. Inovação: um estudo sobre a evolução do conceito de Schumpeter. Caderno de Administração, vol. 5, n. 1, 2011

[341. SAVITSKAYA, I.; SALMI, P.; TORKKELI, M. Barriers to Open Innovation: Case China. Journal of Technology Management\&Innovation, vol.5, n.4, p.10-21, 2010.

[35]. SCHUMPETER, J. Teoria do Desenvolvimento Econômico: uma investigação sobre lucros, capital, crédito, juro e o ciclo econômico. São Paulo: Editora Nova Cultural, 1997.

[36]. SILVA, G.; DACORSO, A. Perspectivas de Inovação na Micro e Pequena Empresa. Revista Economia \& Gestão, PUC Minas. vol. 13, n. 33, p. 90-107, 2013.

[37]. TIDD, J.; BESSANT, J.; PAVIT, K. Gestão da inovação. 3aㅡ Ed. Porto Alegre: Bookman, 2008.

[38]. TIGRE, P. Gestão da Inovação: a economia da tecnologia no Brasil. 2ª ${ }^{a}$. Ed. Rio de Janeiro: Campus Elsevier, 2014.

[39]. TROT, P. Gestão da Inovação e Desenvolvimento de Novos Produtos. Porto Alegre: Bookman. 2012.

[40]. UTTERBACK, J. Mastering the Dynamics of Innovation: how companies can seize opportunities in the face of technological change. Harvard Business School Press Boston, MA, USA, 1994

[41]. VAN DE VEN, A. Central Problems in the Management of Innovation. Management Science, vol. 32, n. 5, p. 590-607, 1986.

[42]. ZANELLA, W.; FRÂNCIO, S.; AGOSTINI, M.; RECH, E. A inovação sob a visão dos gestores de duas Instituições públicas. ReFAE Revista da Faculdade de Administração e Economia, vol. 4, n. 1, p. 107-127, 2012. 


\section{Bapítulo 2}

\section{A IMPORTÂNCIA DA GOVERNANCA CORPORATIVA E DO COMPLIANCE NA MOBILIDADE URBANA EM UMA LOCADORA DE VEICULOS}

\section{Alan Amorim de Jesus}

\section{Rita de Cassia Costa da Silva Holanda Moacir de Freitas Junior}

Resumo: O compliance, devido a sua importância no atual momento, deveria ser tratado com bastante efetividade, assim como foram os programas de qualidade ou o de sustentabilidade aplicados nas empresas. Conforme pesquisa feita pela KPMG com 250 empresas no Brasil, onde 45\% eram multinacionais e 55\% nacionais, $58 \%$ já possuem mecanismos desse tipo de programa e que $42 \%$ nem sabem dizer como funciona. Tal constatação nos leva ao questionamento da conduta ética no cenário atual, condição que em breve tempo poderá até significar a permanência ou não da empresa no mercado. O compliance surge num momento onde empresas são denunciadas por fraudes ou por condutas ilegais, sendo fortemente penalizadas por isso, como foram os casos recentes da Siemens e da Alstom. Sua base está focada no cumprimento das normas e regulamentações, dentro de sua política interna onde um dos maiores beneficiados serão seus stakeholders. Esse trabalho apresenta a influência e os resultados que se obtém com a implantação e a gestão do tema dentro das mesmas e os ganhos em seguir o código de conduta criado, aumentando suas margens de lucro. Busca-se nesse trabalho demonstrar o sucesso da aplicação da governança e compliance na empesa Localiza, locadora de veículos, isso pelos resultados apresentados na área de mobilidade urbana.

Palavras-chave: Compliance, Fraudes, Normas, Código de Conduta. 


\section{INTRODUÇÃO}

As empresas de grande, médio ou pequeno porte, de capital nacional ou multinacional, passaram a se preocupar muito nos últimos anos com os crescentes escândalos envolvendo fraudes e condutas temerosas dentro de sua gestão, onde seus líderes criam esquemas de corrupção, sem o consentimento de seus superiores. Isso pode gerar consequências àqueles que em seus procedimentos, criam situações previstas na lei anticorrupção, como os conhecidos casos da Siemens e Alstom que depois de penalizadas, criaram ferramentas para evitar tal condição e hoje, pelos programas implantados, se tornaram exemplos positivos de transparência e ética. Devido a essa preocupação, necessário se faz controlar os processos internos e suas relações com as partes interessadas da empresa, isso de forma a inibir as possibilidades de ocorrerem fraudes pela má conduta dos gestores. Nessa linha de pensamento surge a aplicação da governança corporativa e o compliance.

Esse estudo tem como objetivo analisar por meio de dados o progresso organizacional e financeiro da empresa Localiza Rent a Car, mostrando as características da aplicação desses programas nos processos de mobilidade urbana de locação de veículos, utilizando inclusive técnicas de Logística em seus controles. O objetivo específico do presente estudo foi demonstrar o que é compliance, governança corporativa e suas funções dentro da organização, apresentando como as organizações podem melhorar suas condutas tanto internas, quanto as externas para com os stakeholders além de analisar dentro da Localiza Rent a Car, trazendo melhorias estruturais e financeiras desde 0 início de sua utilização.

Conforme a FEBRABAN (2016), "ser compliance é conhecer as normas da organização, seguir os procedimentos recomendados e agir em conformidade, é seguir o código de conduta da empresa.

A investigação a ser desenvolvida está embasada em uma pesquisa qualitativa, descritiva e bibliográfica, e os instrumentos utilizados na sua elaboração são a análise crítica da literatura pertinente ao tema em livros, teses, dissertações, artigos científicos, bem como informações dadas pelo CEO da empresa estudada e também a utilização dos conceitos organizacionais aplicados e das informações financeiras disponíveis em sua página, que são de fácil acesso pelo motivo da busca da total transparência perante o mercado e seus acionistas.

Este artigo começa apresentado como surgiu toda a preocupação por controles internos e externos para evitar uma relação corruptiva que deverá ser evitada para seguir os preceitos da nova legislação. São apresentados os conceitos chave de nosso estudo, que são a governança corporativa e compliance e, também são apresentados os procedimentos direcionados para a mobilidade urbana e os resultados alcançados com a aplicação dos temas e as considerações finais obtidas.

\section{REVISÃO BIBLIOGRÁFICA}

Segundo a Federação das Indústrias do Estado de São Paulo - FIESP (2013) o custo médio anual estimado da corrupção em nosso país é de $1,38 \%$ a $2,3 \%$ do PIB, totalizando entre $\mathrm{R} \$ 41,5$ bilhões e $\mathrm{R} \$ 69,1$ bilhões, dinheiro esse que não chegou aos destinos propostos. A corrupção está impregnada em todos os setores. A figura 1 mostra um estudo feito pela Transparência Internacional, movimento global com sede em Berlim, que visa um mundo no qual as empresas, governos e sociedades fiquem livres da corrupção. 
Figura 1 - Ranking da corrupção 2017

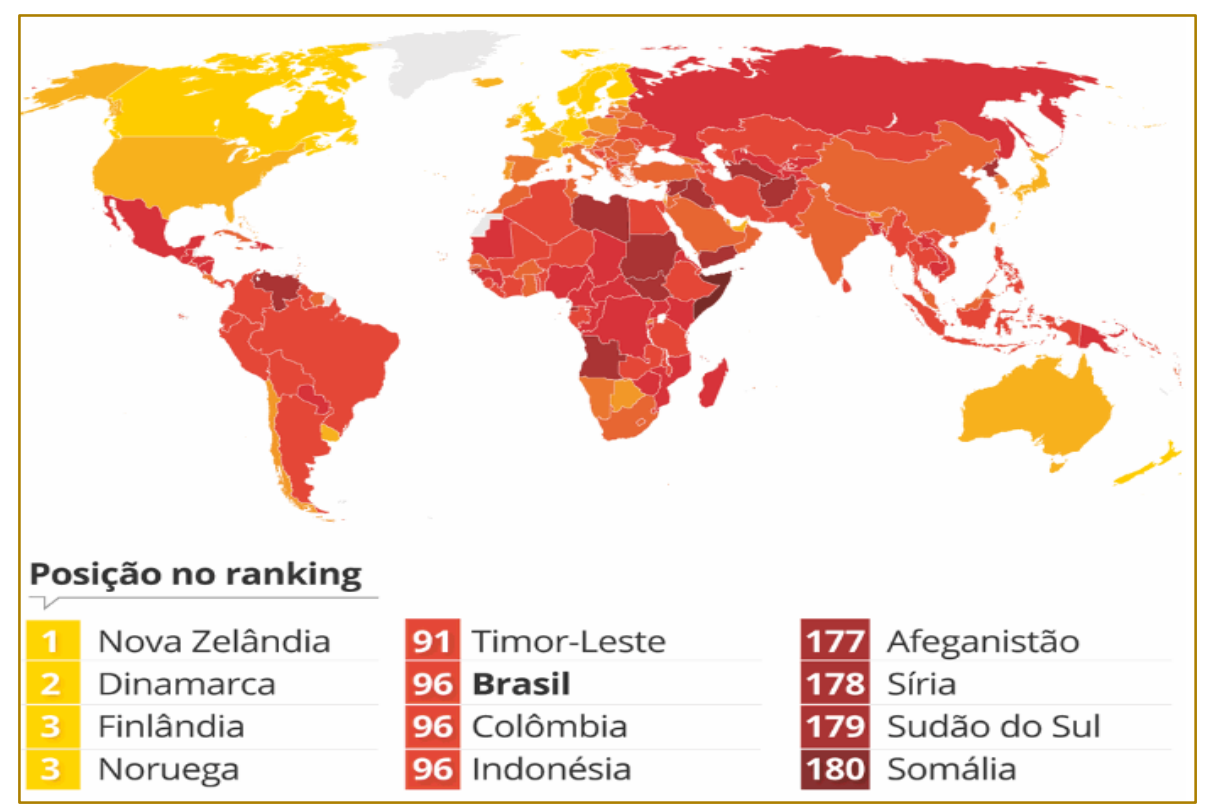

Fonte: Índice de Percepção da Corrupção 2017 da Transparência Internacional

Foi analisada a corrupção no setor público de 180 países, e o Brasil caiu 17 posições desde 2014, ocupando agora a posição 96, ficando atrás de países como Arábia Saudita e TimorLeste. Esse estudo mostra a importância de se preocupar com o tema que denigre a imagem de um país perante o mundo, preocupado cada vez mais com um assunto tão relevante como a globalização e os programas de sustentabilidade e de compliance.

Considerando que a corrupção tem abrangência universal, faz sentido que as soluções ou a busca delas ocorram em âmbito global e a Lei Norte-Americana - FCPA surgiu como um início a esse combate.

Segundo SPORKIN (1977, p. 271) essa Lei foi projetada para combater a corrupção e desestimular corporações norte-americanas a se envolverem em casos de suborno e corrupção no exterior.

A Foreign Corrupt Practices Act- FCPA, conhecida como Lei de Práticas Corruptas no exterior, foi criada em 1977, em resposta ao escândalo Watergate, escândalo político ligado a corrupção ocorrida na década de 1970 nos Estados Unidos, e a FCPA tem como objetivo coibir duas atividades empresariais ilícitas: o suborno e a contabilidade falsa ou imprecisa DE LA TORRE (2016, p. 471). As disposições anticorrupção da FCPA proíbem os pagamentos feitos com "intenção corrupta", e temos alguns exemplos apresentados na figura 2. 
Figura 2 - Top 10 das maiores violações ao FCPA

\begin{tabular}{|c|c|c|}
\hline \multirow[b]{2}{*}{1} & Siemens (énergie, transports) & $\mathbf{\nabla}$ \\
\hline & ALLEMAGNE & 800 (2008) \\
\hline \multirow[b]{2}{*}{2} & Alstom (énergie, transports) & \\
\hline & FRANCE & 772 (2014) \\
\hline \multirow[b]{2}{*}{3} & KBR / Halliburton (ingénierie pétrolière) & \\
\hline & 579 & \\
\hline \multirow{3}{*}{4 致 } & BAE (aéronautique, défense) & \\
\hline & 400 (2010) & \\
\hline & Total (énergie) & \\
\hline \multirow[t]{2}{*}{5} & FRANCE & \\
\hline & Alcoa (aluminium) & \\
\hline \multirow[t]{2}{*}{6} & ETATS-UNIS & \\
\hline & Snamprogetti (énergie) & \\
\hline \multirow[t]{2}{*}{7} & ITALIE $\quad 365$ (2010) & \\
\hline & Technip (ingénierie pétrolière) & \\
\hline & \begin{tabular}{|l|l|} 
FrancE & 338 \\
\end{tabular} & \\
\hline & JGC Corporation (énergie) & \\
\hline \multirow[t]{2}{*}{$9 \bullet$} & \begin{tabular}{|ll} 
JAPON & $\mathbf{2 1 8 , 8}(2011)$
\end{tabular} & \\
\hline & Daimler (automobile) & \\
\hline 10 & ALLEMGNE 185 (2010) & \\
\hline
\end{tabular}

Fonte: Adaptado de www.la-croix.com

Desde o surgimento dessa lei, várias multas foram geradas para empresas que as infringiram, e dentre elas, em primeiro lugar está a Siemens, caso que gerou bastante repercussão. A empresa e a Alstom foram pressionadas a realizar um compliance visando descobrir as más condutas corporativas, pois houveram denúncias de que ambas as empresas pagavam propinas em suas filiais no mundo para conseguir grandes negócios aproveitando-se de brechas na contabilidade.

Conforme PLANALTO (2013), a lei Anticorrupção brasileira ํo 12.846/2013 de 1o de Agosto de 2013, que entrou em vigor no país dia 29 de Janeiro de 2014, foi impulsionada por um acordo entre o Brasil e a Organização para a Cooperação e Desenvolvimento Econômico - OCDE, com sede em Paris, seu objetivo é de potencializar seu crescimento econômico e colaborar com - desenvolvimento dos demais países membros, no qual 36 países se comprometeram a criar legislações que fossem absolutamente eficientes no combate à corrupção.

Segundo a própria Lei, estão sujeitas a ela as sociedades empresariais, independentemente da forma de organização ou modelo societário adotado e sociedades estrangeiras, que tenham sede, filial ou representação no território brasileiro, ainda que temporariamente.

O não cumprimento da Lei consiste em multa de $0,1 \%$ a $20 \%$ do faturamento bruto do último exercício anterior ao da instauração do processo administrativo ou multa de $\mathrm{R} \$ 6$ mil a $\mathrm{R} \$ 60$ milhões de reais, com reparação integral do dano, além de aplicar devidas punições ao envolvidos.

Para reduzir a multa, a empresa pode optar por um acordo de leniência, evitando que seja obrigada a publicar a decisão punitiva, redução da multa em até dois terços (2/3) do valor total e não menos importante, uma previsão de adoção de programa de integridade (compliance). Para a empresa, a melhor maneira é evitar que seja necessário chegar a aplicar esse acordo, assim se faz importante ter uma boa governança e um bom programa para não somente evitar esse tipo de situação, mas também progredir tanto organizacionalmente quanto financeiramente, como será apresentado nesse trabalho.

\section{GOVERNANÇA CORPORATIVA}

O ambiente empresarial, assim como tudo em nossa volta, passou e passa por mudanças constantes com o decorrer do tempo, e cabe às empresas serem flexíveis e evoluírem junto 
com tudo que as afetam. Uma empresa deve apenas captar recursos de seu capital próprio e/ou de terceiros, como investidores ou acionistas. No caso dos acionistas nas empresas de capital aberto, estes passam a ter responsabilidades nas decisões, e aqui encontramos um ponto importante a ser discutido que é a necessidade de os gestores se adaptarem a um novo perfil junto aos parceiros sociais, surgindo a Governança Corporativa (empresas de capital fechado também aplicam esse programa, a figura daquelas de capital aberto foi exemplificada, pois é de mais fácil visualização a existência de governança).

Para SILVA (2012), governança corporativa é um conjunto de práticas que têm por finalidade aperfeiçoar o desempenho de uma companhia, protegendo investidores, empregados e credores, facilitando, assim, o acesso ao capital.

SILVEIRA (2010, p. 7) completa dizendo que uma boa governança traz dois principais benefícios: os benefícios externos, como facilidade de captação de recursos e a redução do custo de capital; e os benefícios internos, vinculados ao aprimoramento do processo decisório na alta gestão.

A implantação exige um investimento, mas se bem feito, pode aumentar o crescimento e o desenvolvimento das mesmas, porém uma má governança pode afetá-las negativamente. Segundo o Instituto Brasileiro de Governança Corporativa - IBGC (2015), a governança se baseia em quatro princípios, que serão apresentados a seguir.

\subsection{TRANSPARÊNCIA (DISCLOSURE)}

ANDRADE \& ROSSETI (2014) explicam que o princípio da transparência envolve a divulgação das informações transmitidas aos principais interessados na organização, especialmente aqueles de alta relevância, que causam impacto nos negócios e que envolve risco ao empreendimento.

\subsection{EQUIDADE (FAIRNESS)}

Segundo o IBGC (2015), esse princípio caracteriza-se pelo tratamento justo e isonômico de todos os sócios e demais partes interessadas (stakeholders), levando em consideração seus direitos, deveres, necessidades, interesses e expectativas.

\subsection{PRESTAÇÃO DE CONTAS (ACCOUNTABILITY)}

Esse princípio os agentes devem esclarecer seus gastos para prestar contas ao conselho, pois assim como diz ANDRADE \& ROSSETTI (2014), prestação responsável de contas fundamenta nas melhores práticas contábeis e de auditoria.

\subsection{RESPEITO ÀS LEIS (COMPLIANCE)}

Conforme ANDRADE \& ROSSETI (2014), o princípio compliance representa a conformidade quanto ao cumprimento de normas reguladoras, expressa nos estatutos sociais, nos regimentos internos, nas instituições legais do País e na legislação em vigor.

Pode-se dizer que esse princípio é um dos mais importantes, pois ao seguir as normas você evita erros nos demais princípios, nos âmbitos internos e externos da empresa.

\section{COMPLIANCE}

Atualmente sabemos que o mundo financeiro está passando por uma crise de corrupção, e que a cada investigação, mais empresas e/ou empresários surgem envolvidos nesse colapso. E devido a esse problema mundial, os programas de Compliance, que surgiram e estão sendo usados desde 2001 nos Estados Unidos, e estão cada vez mais presentes nas empresas brasileiras, conforme ANTONIK (2016):

"No Brasil o Compliance ganhou significância após a regulamentação da Lei Anticorrupção (Lei $n^{\circ}$ 12.846, de $1^{\circ}$ de agosto de 2013) ou Lei Compliance, cujo instrumento normativo dispõe sobre responsabilização administrativa e civil de pessoas jurídicas, de qualquer natureza ou formato societário, pela pratica de atos contra a administração pública nacional ou estrangeira. "(ANTONIK 2016, p. 50).

No Brasil, o programa começou a ganhar o foco das empresas a partir de 2015, devido aos grandes escândalos de corrupção envolvendo, por exemplo, a Petrobrás. 


\subsection{O QUE É COMPLIANCE}

Segundo SERPA (2016), o termo é um substantivo ou verbo derivado da língua inglesa "to comply" que significa seguir as regras. Descrevendo melhor o termo, significa agir de acordo com as normas de conduta pré-estabelecidos pela organização e de encontro a isso, seguir também as leis vigentes do país onde a organização está estabelecida. ANTONIK (2016) complementa SERPA com a afirmação a seguir:

"Compliance é um conjunto de regras que assegura o cumprimento de regras de determinado setor. O significado tem como objetivo identificar possibilidades de infrações, falta de cumprimento de uma norma legal ou atividades que se configurem como atos de corrupção" (ANTONIK 2016, p. 50).

Este termo foi criado pelo governo americano que queria eliminar grandes divergências nas sentenças determinadas pelos juízes americanos para empresas que foram investigadas e comprovadas que praticavam condutas ilícitas e eram condenadas. Conforme SERPA (2016),

"Programa de Compliance é algo bem organizado, com diversos componentes, que interage com outros componentes de outros processos e outros temas, algo que depende de uma estrutura mais complexa que inclui pessoas, processos, sistemas eletrônicos, documentos, ações e ideias". (SERPA 2016 p.117)

Para que esse programa exista dentro de uma organização todos os setores e gestores devem estar de acordo para que o programa obtenha resultados, melhorando assim o ambiente de trabalho, a partir de uma política de conduta organizacional eficiente.

ANTONIK (2016, p.47) complementa, "Sob a ótica dos executivos, o Compliance pressupõe atender, além da normatização regulatória e legal, as resoluções internas da companhia".

O programa tem uma estrutura de componentes ou pilares, mínimos que o integram, e que segundo a Federal Sentencing Guidelines, com tradução de SERPA (2016, p. 188), são eles:

1) Avaliação de riscos e determinação de respostas aos riscos;

2) Definição de políticas e procedimentos;
3) Suporte da Alta administração;

4) Comunicação e treinamento;

5) Due diligence (auditoria e acompanhamento) de terceiros;

6) Monitoramento e auditoria, do funcionamento do programa;

7) Disponibilização de um mecanismo para reporte ou auxilio, de forma anônima e/ou confidencial, em relação a conduta, ou suspeita de conduta criminosa;

8) Investigação de, e respostas para, condutas inconsistentes com os objetivos do programa; e

9) Melhoria contínua (reiniciar o ciclo a partir do item 1).

Segundo SERPA (2016, p. 122), "Compliance não é tampouco uma forma de evitar que funcionários sejam punidos, isso é tarefa de advogados criminalistas", ou seja, é um programa para instigar nas pessoas a vontade de seguir as regras, e mostrar que desta forma se obtém melhores resultados para a organização. É necessário que a empresa tenha uma cartilha com todas as regras de conduta da organização, e que a disponibilize para todos os funcionários. Junto a isso é necessário que os líderes de cada setor, da alta administração, sejam muito bem treinados para sejam capazes de sanar quaisquer possíveis dúvidas que venham a surgir de um funcionário. SERPA (2016, p. 132) também deixa claro que este programa não é uma ação anticorrupção, ele é uma ferramenta disponível para as empresas que queiram inibir dentro de sua operação o surgimento de casos de conduta ilícita.

\section{MOBILIDADE URBANA}

Conforme FERRAZ \& TORRES (2004), o crescimento das cidades tem total relação com a evolução dos transportes, pois exercem influência em como as cidades evoluem, além de interferir nas escolhas de transporte da população.

Para ALVARENGA \& NOVAES:

O transporte trata-se de se deslocar espacialmente pessoas ou coisas da origem ao destino, mas quando integrado à logística, além do simples ato de transportar deve-se atentar a outros aspectos como a integridade do bem transportado, confiabilidade no que diz respeito a prazos e a busca de redução 
de custos sem afetar a qualidade no serviço (ALVARENGA \& NOVAES, 2000)

\section{E, segundo FERRAZ \& TORRES:}

- transporte é tão importante para a qualidade de vida da população quanto os serviços de abastecimento de água, coleta de esgoto, fornecimento de energia elétrica, iluminação pública, etc. (FERRAZ; TORRES, 2004).

Segundo BORN (2005 citado por BASQUES, 2006), a mobilidade urbana é a facilidade de deslocamentos das pessoas e bens no espaço urbano. Para BASQUES (2006) pensar na mobilidade urbana é garantir o acesso das pessoas e bens ao que a cidade oferece e não apenas pensar nos meios de transporte e trânsito.

FERRAZ \& TORRES (2004) classificam o transporte urbano de passageiros em: privado ou individual, público e semipúblico.

Segundo o autor, privado ou individual é quando o usuário é dono do veículo e assim tem a liberdade de escolher seu caminho e o horário que o realizará, porém assumem todos os custos, como manutenção, IPVA, combustível, seguro, dentre outros. A classificação do transporte público, coletivo ou de massa, é que são os veículos que operam em rotas predefinidas e horários fixos, onde a viagem é compartilhada por um grande número de passageiros, já que a capacidade do veículo é grande. O número de usuários torna esse meio extremamente desconfortável, estressante e desgastante. O terceiro e último meio de transporte abordado pelo autor é o semipúblico, que são os veículos cujo proprietário pode ser uma pessoa física ou uma empresa, que realiza o transporte de acordo com a necessidade do usuário.

O transporte semipúblico é extremamente interessante, pois possui características do transporte privado, entretanto o usuário só paga o serviço, no caso o tempo de utilização do mesmo, não precisando arcar com outros custos, e isso fez com que na atualidade serviços como Uber e empresas de aluguel de carros, como a Localiza, ganhassem força no mercado.

\section{RESULTADOS E DISCUSSÃO}

A Localiza foi escolhida para demonstrar o quanto a aplicação da governança corporativa e do compliance pode ser positiva para qualquer empresa, como a de mobilidade urbana de locação de veículos aqui apresentada, que obtém lucro de maneira crescente em suas 4 divisões, sendo elas a Localiza Hertz responsável pelo aluguel de carros, onde com apoio da Logística, tem uma organizada gestão de frotas, trabalhando com locação para clientes corporativos, a Localiza Seminovos, que é a divisão que realiza a venda de veículos seminovos de aluguel de carros e também o controle de frotas e a Localiza Franchising, que é um modelo baseado em franquias. Em 2016, a locação de veículos representou 35\% do faturamento total da companhia, a venda de seminovos $50 \%$ e os outros $15 \%$ vem da gestão de frotas.

A revista exame lançou uma edição especial em 2017 com as Melhores e Maiores empresas do Brasil e a Localiza ocupou o $147^{\circ}$ lugar no ranking das maiores empresas de capital aberto da América Latina, (no ano anterior ocupava o 180 lugar) obtendo um lucro de US\$2.185.000,00 e com um crescimento de 30,5\% com relação ao ano anterior. No ranking das melhores empresas no setor de serviços, a Localiza ocupou o $4^{\circ}$ lugar. Os dados mais atuais da empresa mostram um lucro líquido no 4ำ trimestre de 2017 de $\mathrm{R} \$ 174,5$ milhões, representando um aumento de $67,1 \%$ em relação ao 4 - trimestre de 2016 , crescimento de $48 \%$ do volume de locação de carros e $22 \%$ de frotas e $67 \%$ no lucro por ação. É importante ressaltar que todos os dados apresentados são disponibilizados pela empresa que possui total transparência com seus resultados financeiros.

\section{CONSIDERAÇÕES FINAIS}

O presente estudo buscou por fundamentos teóricos e práticos demonstrar o que é governança corporativa e compliance, quais as suas funções dentro de uma organização e como as organizações devem utiliza-las para melhor desempenho de mercado.

Percebeu-se o quanto os temas ainda são assuntos inexplorados pelas organizações, onde muitas entendem de forma incorreta quais as suas verdadeiras funções e importância que esses programas tem para melhorar os resultados perante o mercado, mesmo após o surgimento de escândalos causados com a criação e uso desse programa desde 2001 nos EUA, como os casos da Siemens e Alstom, e que desde 
2013 vem ganhando o foco das organizações no Brasil por causa da Lei Anticorrupção.

No que se refere ao Compliance, verifica-se que não é um programa que visa evitar a corrupção depois de constatada na organização, e sim, que seja implantada antes de qualquer percepção de má conduta, assim seus resultados são mais eficientes com relação à estrutura organizacional e com as finanças da empresa.

Tais programas que devem ter o envolvimento de toda a empresa e de todos os colaboradores, internos e externos, principalmente da alta gestão, para que assim todos estejam em transparência e que seguir a conduta passe a ser cultural para todos.

Com a forma da transparência interna e externa em seus dados financeiros, perante seus acionistas, seus sócios, fornecedores,

\section{REFERÊNCIAS}

[1]. AlvarenGA, A. C.; NOVAES, A. G. N Logística aplicada: suprimento e distribuição física. 3. ed. São Paulo: Blucher, 2000.

[2]. ANDRADE, A.; ROSSETTI, J. P. Governança Corporativa: fundamentos, desenvolvimento e tendências. São Paulo: Atlas, 2014

[3]. ANTONIK, L. R. Compliance, Ética, Responsabilidade Social e Empresarial - Uma Visão Prática. Editora Alta Books. 1aㅡ edição, Rio de Janeiro,2016.

[4]. BASQUES, B. F. S. Análise da mobilidade urbana na Rua Amando de Barros. 2006. 75 f. Monografia (Tecnólogo em Logística e Transporte) - Faculdade de Tekhne e Logos, Botucatu, SP, v.3, n.3, Novembro. 2012181 Tecnologia de Botucatu, Botucatu - SP. 2006.

[5]. BRASIL. Presidência da República. Casa Civil, Subchefia para Assuntos Jurídicos, 2013. Disponível <http://www.planalto.gov.br/ccivil_03/_Ato20112014/2013/Lei/L12846.htm.> Acesso em: 04 mar. 2018 .

[6]. CUSTO da corrupção no brasil chega a R\$ 69 bi por ano, 2013. Disponível em http://www.fiesp.com.br/noticias/custo-dacorrupcao-no-brasil-chega-a-r-69-bi-por-ano/> . Acesso em 04 mar. 2018

[7]. DE LA TORRE, M. J. The Foreign Corrupt Practices Act: Imposing an American Definition of Corruption on Global Markets. Cornell International Law Journal, v. 49, spring 2016, p. 469-495. colaboradores e franqueados ajudaram a alavancar a visão de mercado da empresa, trazendo benefícios como a avaliação, controle e otimização de sistemas de informação, minimização dos riscos fiscais e do negócio, fornecendo assim os principais dados para que futuros acionistas e sócios percebam que não existe perigo e/ou divergência nos dados para investimentos.

Conclui-se que obter uma governança corporativa estruturada e um bom programa de compliance não é somente fundamental no combate a irregularidades, más condutas e possíveis atos corruptos, mas sim fundamental para o desenvolvimento organizacional e financeiro da empresa, pois o mercado, sócios, acionistas, fornecedores e clientes passam a confiar na empresa de uma forma a todos os evolvidos se favorecerem de forma conjunta.

[8]. FEBRABAN. Função de compliance. Disponível em: <http://www.febraban.org.br/7rof7swg6qmyvwjcfwf 7iOasdf9jyv/sitefebraban/funcoescompliance.pdf. . . Acesso em 25 mar. 2018.

[9]. FERRAZ, A. C. C. P. F.; TORRES, I. G. E. Transporte público urbano. São Carlos: Trima, 2004.

[10]. GOMIDE, A. A. Transporte Urbano e Inclusão Social: Elementos para Políticas Públicas. Instituto de Pesquisa Econômica Aplicada. Brasília. 2003.

[11]. INSTITUTO BRASILEIRO DE GOVERNANÇA CORPORATIVA. Código das melhores práticas de governança corporativa. São Paulo: IBGC, 2015.

[12]. SERPA, A. C. Compliance Descomplicado, uma guia simples e direto sobre Programas de Compliance. Edição1, 2016.

[13]. SILVA, E. C. Governança corporativa nas empresas: guia prático de orientação para acionistas, investidores, conselheiros de administração e fiscal, auditores, executivos, gestores, analistas de mercado e pesquisadores. São Paulo: Atlas, 2012.

[14]. SILVEIRA, A. D. M. Governança Corporativa no Brasil e no Mundo: teoria e prática. Rio de Janeiro: Elsevier, 2010.

[15]. SPORKIN, S. The Worldwide Banning of Schmiergeld: A Look at the Foreign Corrupt Practices Act on its Twentieth Birthday. J. Int'l L. \& Bus., v. 18. 


\section{Capítulo 3}

\section{A INICIATIVA NA GESTÃO DE PROJETOS: ANÁLISE DE UM CURSO DE PROFISSIONALIZANTE EXTENSÃO EM ESCOLA}

\section{Renan Santos Destefani}

Edilson Silva Araújo

Vanina Carrara Sigrist

Resumo: A gestão de projetos em educação é uma área de extrema relevância num cenário atual de ensino e aprendizagem repleto de mudanças e desafios. Um problema que se apresenta, nesse contexto, é a falta de iniciativa para que novos projetos sejam executados. O objetivo deste artigo foi destacar o papel da iniciativa na elaboração de projetos multidisciplinares, especialmente em instituições de ensino, tomando por referência um curso de extensão promovido na Escola Técnica Dona Escolástica Rosa (ETEC), situada em Santos (SP). A pesquisa teve viés exploratório e qualitativo. Pautou-se em métodos de revisão bibliográfica, de pesquisa de campo, com aplicação de questionário para 14 professores e 108 alunos da ETEC em questão, no ano de 2016, e de análise estatística descritiva e interpretativa. Os resultados indicaram que as experiências com o curso de extensão apontam para a necessidade de fomento contínuo a projetos interdisciplinares que estreitem relações entre alunos, professores e gestores, e ressaltaram também a urgente necessidade de todos serem colaborativos numa cultura educacional voltada às novas tecnologias. Foi possível concluir que a iniciativa de criação de projetos multidisciplinares é um diferencial nas instituições de ensino.

Palavras-chave: Iniciativa. Gestão de projetos. Educação profissionalizante. 


\section{INTRODUÇÃO}

Um dos maiores desafios da educação básica no Brasil é a carência de motivação e dedicação por parte de alunos, professores, gestores e diretores. Quando se trata especificamente de instituições públicas, o problema se agrava, devido à escassez de recursos financeiros e culturais, à dependência de tomadas de decisão políticas, à influência de fatores ambientais nocivos, como alto índice de violência em determinadas regiões e comunidades, e agora a mais recente vulnerabilidade econômica das carreiras dos servidores públicos.

Os resultados de desempenho da maioria das crianças e dos jovens escolarizados em importantes provas de avaliação nacional, como o Exame Nacional do Ensino Médio (ENEM) e de vestibulares por todo o país, como consequência, são ainda bem insatisfatórios. Sabe-se que a educação é uma área vital para o desenvolvimento humano e econômico de qualquer sociedade, que, entretanto, padece de investimentos, por antes padecer de desmerecimento e desvalorização.

Segundo dados do Instituto Unibanco (2016), com base nos últimos dados do Instituto Brasileiro de Geografia e Estatística (IBGE), há 1,7 milhão de jovens fora da escola sem concluir os estudos, dos quais 52\% ainda nem sequer concluíram o ensino fundamental. Esse grupo, ainda de acordo com o relatório, é o mais vulnerável, porque com a evasão escolar - um grave problema da educação brasileira - aumenta fortemente a probabilidade de sua inserção no mercado de trabalho ser bastante precária.

$\mathrm{Na}$ educação profissionalizante, o cenário também é desafiador. Segundo dados do Centro Estadual de Educação Tecnológica Paula Souza - CEETEPS (2011), as evasões nas escolas profissionalizantes como SENAI, SENAC e ETEC chegavam, em média, a $24 \%$, e algumas das causas mencionadas pelas instituições eram: mudança de endereço, obtenção de emprego, necessidade de trabalhar mais, alteração no horário de trabalho, problemas pessoais ou familiares e incompatibilidade com o curso. Essa ainda é a realidade, e, apesar do conhecimento a respeito dessas causas, ações que objetivem encontrar soluções (quando possíveis) apenas começam a ser tomadas, de modo ainda incipiente.
Detregiachi Filho (2012) explora de modo bastante particularizado a realidade da evasão no CEETEPS, com enfoque na Faculdade de Tecnologia de Garça (SP). Sua pesquisa apresenta similaridades com a que foi executada na ETEC em Santos, pois o intuito também era conhecer a percepção do corpo discente e docente face ao status quo do ensino na instituição. As quatro opções com mais citações por parte dos alunos, que justificam a evasão, são: deficiência na educação básica, falta de experiência na área do curso, tempo em que está fora da escola e falta ou dificuldade de transporte.

Existe uma percepção equivocada no Brasil de que a responsabilidade pela evasão seria unicamente do aluno, além de escassa discussão sobre o tema e seus complexos fatores de existência dentro das próprias escolas, e também faculdades e universidades. Há de se considerar como outros motivos do abandono dos cursos a incompatibilidade entre o nível de exigência requerido para a obtenção do diploma e o perfil de formação do alunado que ingressa e a falta de comprometimento dos docentes, gestores e coordenadores, que nem sempre assumem para si a tarefa de resolver problemas externos, que, a seu ver, não lhes competem.

É possível elencar algumas atitudes percebidas nos mais diversos ambientes educacionais (e, em certa medida, também naquele que será estudado aqui), vindas de alunos, professores, coordenadores e diretores: comodismo, desinteresse, desmotivação, não engajamento, ceticismo, cristalização de certos modelos e práticas, baixa comunicação entre seus pares e os demais grupos formadores da instituição, descrença no papel transformador da educação.

O que falta, sob a perspectiva adotada nesta pesquisa, é iniciativa. Iniciativa de todos os envolvidos para que o diálogo seja constante e significativo; para que a cultura seja comum e permanentemente enriquecida pela contribuição de todos. Afinal, discutir educação hoje implica necessariamente tratar das novas características e dos novos modelos que têm se fortalecido, principalmente pelas novas tecnologias de comunicação.

Mas é necessário admitir que diversas iniciativas têm sido tomadas no sentido de formar aprendizes e profissionais com 
múltiplas competências, com forte embasamento técnico, preparados para os novos desafios de uma sociedade digital, e que, inclusive, concluam efetivamente seus cursos, superando, assim, os casuais, mas insistentes, obstáculos que conduzem à evasão escolar.

Portanto, o objetivo deste artigo é discutir o papel da iniciativa na elaboração e gestão de projetos multidisciplinares em instituições de ensino. Para tanto, será apresentada a proposta de um curso de extensão promovido na Escola Técnica Dona Escolástica Rosa, situada em Santos (SP), no ano de 2016, justamente durante a realização desta pesquisa de campo, cuja finalidade era entender os motivos do insucesso escolar. Esse curso envolveu alunos de diversas turmas e um número considerável de professores e gestores, com o intuito de fortalecer a troca de ideias e experiências entre todos.

A pesquisa teve viés exploratório e qualitativo. Pautou-se em métodos de: 1. revisão bibliográfica - notadamente trabalhos sobre educação profissionalizante e os novos rumos da educação digital e sobre gestão de projetos; 2. de pesquisa de campo - foi aplicado um questionário com quatro perguntas dissertativas para 14 professores e 108 alunos da ETEC Dona Escolástica Rosa, com o objetivo de conhecer as opiniões sobre o ensino vigente daqueles diretamente envolvidos no curso que seria realizado; e 3. de análise estatística descritiva e interpretativa das respostas obtidas.

Este artigo começa por apresentar o embasamento teórico do problema. $\mathrm{Na}$ sequência, será realizado o desenvolvimento da temática, seção em que serão mostrados os dados relativos à pesquisa de campo na escola referida. Posteriormente, será feita a apresentação dos resultados e da discussão, bem como da conclusão.

\section{EMBASAMENTO TEÓRICO OU REVISÃO DA LITERATURA}

Se, há alguns anos, autores como Polity (2002) mencionavam dificuldades como a distância cultural entre as escolas públicas e a comunidade que elas atendem, a precária formação dos professores, a ineficácia dos métodos, preconceito e segregação, somamse a essas outras pertinentes ao acesso e, principalmente, à experiência (que deve ser construída também na escola) com materiais e conhecimentos digitais, hoje imprescindíveis.

De acordo com Prensky (2001), muitos dos alunos atualmente matriculados no ensino básico correspondem às primeiras gerações que já nasceram com as novas tecnologias, e passaram sua vida inteira cercados por dispositivos digitais - videogames, computadores, câmeras de vídeo, celulares e todas as outras ferramentas desta era. A nova geração, chamada de D-gen [Digital] ou, mais popularmente, Nativos Digitais, ocupa atualmente as salas de aula tanto de escolas públicas quanto de particulares. Ao seu lado, encontram-se os chamados Imigrantes Digitais, que, segundo Prensky (2001), são aqueles que nasceram antes das atuais tecnologias de comunicação e precisaram se adaptar a elas. O autor relata a dificuldade de aceitação dessas tecnologias pelos imigrantes digitais, inclusive no setor da educação, por não acreditarem que os alunos possam aprender em sala de aula enquanto utilizam seus dispositivos móveis, mexem em seus aparelhos eletrônicos, escutam músicas ou assistem vídeos.

Cursos de capacitação e treinamentos teriam, nesse sentido, de ser constantemente oferecidos aos professores e seus superiores para que práticas mais condizentes com o mundo atual dos alunos fossem experimentadas. Em contrapartida, também esses alunos precisariam sair de sua zona de conforto para se mostrarem abertos a um modelo de aula menos convencional, com menos roteiro e mais improviso, menos conteúdo programado e mais iniciativa de sua parte para a resolução de problemas reais, interligando diferentes disciplinas aprendidas.

Segundo o dicionário Michaelis (2018, versão digital), iniciativa significa 1)qualidade de quem concebe e executa espontaneamente qualquer coisa, 2)ser o primeiro a propor e pôr em prática qualquer coisa.

Dentro de um ambiente organizacional, a iniciativa cumpre papel fundamental:

A iniciativa é o combustível que alimenta o sucesso. Podemos ter dois funcionários com uma habilidade cognitiva idêntica, mas aquele que toma iniciativa de ultrapassar paradigmas alcança mais sucesso. Como gerentes, precisamos estimular a iniciativa dos colaboradores. Essa atitude possibilita que o membro da equipe se torne um empreendedor, assumindo 
responsabilidade pela tarefa que tem diante de si. Isso funciona para os meus colaboradores e para o ambiente no qual trabalhamos (DEATRICK, apud NELSON, 2008, p.106).

Segundo Kesley (2013), a iniciativa geralmente se compõe de quatro elementos: 1. Fazer algo que esteja acima e transcenda a função de um indivíduo; 2. Ajudar outras pessoas; 3. Correr riscos; e 4. Acompanhar uma atividade até sua conclusão. Tais elementos resumem algumas habilidades que um profissional precisa desenvolver para poder crescer num ambiente laboral amistoso, saudável e produtivo, para que se mostre proativo à sua empresa, trazendo bons resultados, gerando valores, até para si mesmo. Além disso, esses elementos pensados por Kelley também estão presentes na área organizacional em foco aqui - a de gestão de projetos.

Um projeto é uma organização de pessoas dedicadas que visam atingir um propósito e um objetivo específico. Os projetos geralmente envolvem gastos, ações únicas ou empreendimentos de altos riscos, e têm de ser completados numa certa data por um montante de dinheiro, dentro de alguma expectativa de desempenho. No mínimo, todos os projetos necessitam ter seus objetivos bem-definidos e recursos suficientes para poderem desenvolver as tarefas requeridas. (TUMAN, 1983, p.26).

Projetos envolvem necessariamente ideias que possam solucionar problemas e trazer sugestões de ações, envolvem equipes formadas por profissionais de diferentes setores e competências, envolvem desafios de execução e implementação, envolvem mudanças de rota e necessidade de resultados. Gestão de projetos escolares também. Equipes de professores e alunos, sob consentimento e ocasional supervisão de outros gestores, dedicam-se a fortalecer o interesse pelo conhecimento e pela pesquisa, pela vontade de inovar e sair do comodismo, por meio de aulas dinâmicas e projetos que possam proporcionar a todos uma aprendizagem exponencial.

Porém, a falta de iniciativa é um dos maiores obstáculos. Muitos alunos só fazem o que Ihes é exigido, tiram vantagem de colegas mais dedicados nas atividades avaliativas propostas e adotam a "lei do mínimo esforço", adquirindo pouco conhecimento e não se envolvendo mais afetivamente com a instituição que frequentam. Alunos com esse perfil, sem iniciativa, não terão sucesso em meio aos novos rumos que já toma a educação brasileira. Tampouco professores que repetem há anos as mesmas aulas, com os mesmos conteúdos, no extremo oposto de uma realidade extremamente dinâmica e instável. Ferramentas ultrapassadas, meios de comunicação anacrônicos, métodos de avaliação engessados e pouco afeitos à diversidade de competências já existentes dentro de uma sala de aula são alguns entraves à iniciativa de projetos consistentes, direcionados à solução de problemas e processos atuais.

Não à toa tem-se discutido com mais ênfase nos últimos anos no Brasil um método educacional intitulado Aprendizagem Baseada em Projetos (FERNANDES; FLORES; LIMA, , que, assim como a Aprendizagem Baseada em Problemas (SAKAI; LIMA, 1996; THOMSON, 1996) e outras metodologias ativas (mais fortemente praticadas em instituições de ensino estadunidenses e europeias), focam na autonomia dos alunos em relação ao conhecimento em oposição à figura de autoridade do professor, e em práticas - mais contextualizadas, coletivas e flexíveis - de discussão dos assuntos obrigatórios.

De acordo com Leite (1996, p.24)

Ao participar de um projeto, o aluno está envolvido em uma experiência educativa em que o processo de construção de conhecimento está integrado às práticas vividas. Esse aluno deixa de ser, nessa perspectiva, apenas umaprendiz do conteúdo de uma área de conhecimento qualquer. É um ser humano que está desenvolvendo uma atividade complexa e que nesse processo está se apropriando, ao mesmo tempo, de um determinado objeto do conhecimento cultural e ser formando como sujeito cultural.

Esse panorama teórico pode ainda ser incrementado pelo artigo 42 da Lei de Diretrizes e Bases da Educação Nacional (Lei № 9.394, de 20 de dezembro de 1996), que disciplina sobre um papel fundamental das instituições de ensino: "Art. 42. As escolas técnicas e profissionais, além dos seus cursos regulares, oferecerão cursos especiais, abertos à comunidade, condicionada a matrícula à capacidade de aproveitamento e não necessariamente ao nível de 
escolaridade". (BRASIL, 1996, s/p). Nessa categoria enquadram-se os cursos de extensão, destinados a uma comunidade muito mais ampla do que a pertencente oficialmente à instituição que os oferece, e que podem ser propícios ao fomento da interdisciplinaridade, ao engajamento dos familiares dos alunos no projeto pedagógico, à perspectiva aplicada e contextualizada do conhecimento - característicos das metodologias ativas e do cenário sócio histórico contemporâneo.

\section{DESENVOLVIMENTO DA TEMÁTICA}

A pesquisa de campo foi realizada com o objetivo de investigar as percepções de alunos e professores da ETEC Dona Escolástica Rosa acerca das possíveis dificuldades pelas quais passavam, devido, principalmente, à falta de iniciativa para criação e gestão de projetos.

Tal pesquisa ocorreu entre os dias 30 de abril de 2016 e 10 de outubro de 2016, mediante aplicação de um questionário digital, enviado a participantes de duas turmas do Curso Técnico em Administração, com 108 alunos e 14 professores, totalizando 122 respostas. Durante essa fase da pesquisa, observou-se que havia sido proposto um curso de extensão por iniciativa dos coordenadores das turmas envolvidas e da direção da ETEC. Consequentemente, foi possível acompanhar o desenvolvimento desse projeto ao longo dos meses em que a pesquisa de campo se desenrolava.

A instituição Dona Escolástica Rosa foi fundada em $1^{\circ}$ de janeiro de 1908, e foi destinada a abrigar meninos pobres e órfãos da cidade de Santos, que precisavam receber educação, cultura e uma profissão. João Octávio dos Santos era filho bastardo de Escolástica Rosa. Aos 69 anos, sentindo que já não estava bem de saúde, fez um testamento para doar parte de seus bens para a Santa Casa e outra parte para a construção de uma instituição educacional que abrigasse esses meninos. Ele faleceu em 09 de julho de 1900, portanto o Instituto Dona Escolástica Rosa só viria a ser inaugurado quase oito anos após sua morte.

A partir de 2003, a escola foi assumida pelo Centro Paula Souza, quando, assim, se transformou em escola técnica estadual, atendendo a cerca de 1.100 alunos. No ano de 2008, Centenário do Escolástica Rosa, foram inaugurados os cursos de Contabilidade e Secretariado, que se juntaram aos de Administração, Metalurgia, Nutrição e Dietética, e passava a aplicar vestibulinho para mais de 6.000 estudantes disputarem as 400 vagas oferecidas pela instituição.

A finalidade do curso de extensão realizado no ano de 2016 era ajudar alunos da própria ETEC e demais interessados externos a obterem melhor desempenho em provas de concurso público. Desse modo, foram eleitas três disciplinas - Língua Portuguesa, Matemática Financeira e Gestão de Pessoas a serem ofertadas à comunidade, para que os participantes pudessem suprir possíveis deficiências nessas áreas e aprofundar seus conhecimentos, preparando-se, então, para futuras avaliações.

As inscrições foram efetivadas mediante doação de um quilo de alimento não perecível, a ser destinado a instituições beneficentes da cidade de Santos. As aulas eram ministradas aos sábados, nas dependências da ETEC, pelos professores das disciplinas de Língua Portuguesa, Matemática Financeira e Gestão de Pessoas.

Cada módulo do curso de extensão teve duração de um dia. Integrou diretamente sete pessoas responsáveis pela organização - a então diretora, uma coordenadora pedagógica, uma coordenadora do curso de Administração, os três professores mencionados e um aluno voluntário -, porém, segundo seus depoimentos, pode-se considerar que o projeto terminou por envolver todo o corpo docente da instituição, seus gestores e, principalmente, muitos membros da comunidade ao redor da escola.

De acordo com alguns dos envolvidos, se o curso tivesse sido divulgado mais amplamente para além dos muros da escola, certamente alcançaria ainda mais sucesso, pois faria com que a iniciativa fosse mais conhecida e servisse realmente como uma oportunidade, principalmente àqueles com vontade de aprender e se dedicar, mas que não necessariamente têm condições financeiras de acesso a cursos preparatórios pagos.

\section{RESULTADOS E DISCUSSÃO}

De acordo com o questionário aplicado aos alunos e professores da amostra levantada, muitos fatores relacionados às práticas pedagógicas e ao cotidiano sociocultural escolar poderiam ser melhorados, visto que a 
percepção de que as aulas, a didática, o convívio mereciam ser repensados, foi generalizada. No Quadro 1, foram selecionadas algumas observações dos alunos sobre o que julgavam ser a postura mais respeitosa por parte do professor:

Quadro 1. Depoimentos dos alunos sobre como deveria agir o professor

\begin{tabular}{cl}
$\begin{array}{c}\text { Aluno A do Período } \\
\text { Matutino }\end{array}$ & $\begin{array}{l}\text { "Deve preparar a aula com antecedência, mostrar domínio em relação à matéria e } \\
\text { ser pontual" }\end{array}$ \\
\cline { 2 - 3 } & $\begin{array}{l}\text { "Respeitar os horários de aulas, ter foco nas explicações das matérias, manter o } \\
\text { respeito entre alunos e professores, e não deixar que perguntas fora do conteúdo } \\
\text { tirem sua atenção da aula e volte para assuntos pessoais" }\end{array}$ \\
Aluno C do Período & "O professor deve buscar a melhor forma de passar o conteúdo para o aluno, ser \\
Matutino & flexível, ser profissional, e entender as necessidades do aluno"
\end{tabular}

Fonte: Os autores (2018)

Como pode ser visto, a pontualidade, o conhecimento prévio do conteúdo e a dedicação em sua preparação, e uma condução de aula não dispersiva são os fatores que predominaram nas respostas. Em resumo, observou-se que uma postura ética transmitida pelo mestre pareceu desejável aos alunos, em razão de buscarem alguém para tomar como exemplo.

O Quadro 2 apresenta a visão de dois professores, um de cada turma, em relação ao mesmo questionamento e revela novos resultados:

\section{Quadro 2. Depoimentos dos professores sobre como deveriam agir}

Professor A do

Período Matutino

Professor B do

Período Noturno
"Há diversas maneiras de mostrar interesse pela dificuldade de aprendizagem. Auxiliá-lo nas habilidades e competências que deverão ser adquiridos. Mostrar-se interessada em compartilhar os interesses dos alunos e seus anseios profissionais"

"Boas aulas: Conteúdo ministrado da forma mais atrativa possível, buscando o lúdico e relacionamento respeitoso, porém com bastante pessoalidade. Um laço de amizade é sempre um bom caminho. "

Fonte: Os autores (2018)

A importância de ouvir o aluno e considerá-lo em suas particularidades cognitivas, o fortalecimento de um laço interpessoal entre aluno e professor, e a escolha de uma didática mais atraente e prazerosa foram pontos recorrentes das respostas de outros profissionais. Isso corrobora a tendência já vista em diferentes ambientes educacionais de que os alunos hoje precisam de aulas mais dinâmicas e criativas, que chamem sua atenção, contextualizem o conhecimento, correspondam à dinâmica das outras comunicações que eles estabeleçam ao longo do dia fora da escola. Pelos depoimentos a seguir, tem-se uma visão mais nítida a esse respeito. 
Quadro 3. Depoimentos dos alunos sobre os estilos de aula mais atrativos

\begin{tabular}{|c|c|}
\hline $\begin{array}{c}\text { Aluno A do Período } \\
\text { Matutino }\end{array}$ & $\begin{array}{l}\text { "O professor criativo que inova em sua aula atrai o interesse dos alunos. } \\
\text { O professor deve planejar a aula tendo o objetivo de os alunos } \\
\text { assimilarem o conteúdo da matéria" }\end{array}$ \\
\hline $\begin{array}{c}\text { Aluno B do Período } \\
\text { Noturno }\end{array}$ & $\begin{array}{l}\text { "O que me faz focar e ter admiração pelo professor é ter conteúdo, o } \\
\text { professor gostar de dar aula, trazer reportagem pertinente ao assunto da } \\
\text { sua matéria, este é um estilo de aula que tem meu foco } 100 \% "\end{array}$ \\
\hline $\begin{array}{c}\text { Aluno C do } \\
\text { Período Matutino }\end{array}$ & $\begin{array}{l}\text { "Uma aula interativa, que não fique apenas baseada em teorias. Quando } \\
\text { um professor cria novas maneiras de aplicar sua matéria, os alunos } \\
\text { passam a absorver melhor" }\end{array}$ \\
\hline $\begin{array}{l}\text { Aluno D do } \\
\text { Período Noturno }\end{array}$ & $\begin{array}{l}\text { "Para mim é aquela aula com vídeos, apostilas e que o professor interage } \\
\text { com a classe, acho que dessa forma ele conseguirá prender a atenção } \\
\text { dos alunos" }\end{array}$ \\
\hline
\end{tabular}

Fonte: Os autores (2018)

Aulas com aplicações práticas, mais interativas, dialógicas são desejadas pelos alunos entrevistados. Todos os depoimentos recolhidos apontam para tal característica. Porém, é preciso também notar nesses resultados que os alunos demonstraram sempre a vontade de estarem diante de professores que têm o que dizer e ensinar. Em outros termos, a própria formação do docente atrai os alunos, porque percebem que seu discurso é substancioso, seu conhecimento é vasto, ou algo do tipo. É como se soubessem quando o professor tenta gastar o tempo da aula de modo não direcionado ao conteúdo previsto.

Já os resultados nas respostas dos professores aparecem no Quadro 4:

\section{Quadro 4. Depoimentos dos professores sobre os estilos de aula mais atrativos}

$\begin{array}{|ll|}\begin{array}{c}\text { Professor A do } \\ \text { Período Matutino }\end{array} & \begin{array}{l}\text { "Também há muitas atividades, mas todas elas dependerão do papel da classe. } \\ \text { grupo. Alguns gostam de manusear trabalhos. Outros preferem fazer a leitura da } \\ \text { atividade sozinhos, em silêncio" }\end{array} \\ \begin{array}{cl}\text { Professor B do } \\ \text { Período Noturno }\end{array} & \begin{array}{l}\text { "Não preparo atividades diferenciadas, mas preparo e planejo roteiro de todas as } \\ \text { aulas" }\end{array}\end{array}$

Fonte: Os autores (2018)

Enquanto um entrevistado demonstrou maior preocupação com a variedade de estilos de aprendizagem dos alunos, respeitando-os, outro relatou não priorizar um atendimento mais individualizado, pois seu foco era a condução programática do conteúdo. Realmente, o perfil sociocognitivo de cada aluno varia, e muitas vezes o professor tem de trabalhar com turmas numerosas, não conseguindo, assim, atender às idiossincrasias dos participantes, principalmente perante a difícil relação 'conteúdo' x 'duração da aula' (ele sente que precisa percorrer todos os assuntos no tempo certo). No entanto, quando possível, parece desejável que o professor desenvolva estratégias de adaptação desses assuntos às vivências de seus alunos, à realidade sociocultural que encontra diante de si, para facilitar a compreensão da matéria lecionada. Perceber quando e como direcionar determinada aula previamente programada para um público, não raras vezes, muito distante do conhecimento de mundo que ela pressupõe. Sair, enfim, da zona de conforto. 
Quadro 5. Depoimentos dos alunos sobre as atividades didáticas ideais

\begin{tabular}{cl}
$\begin{array}{c}\text { Aluno E do Período } \\
\text { Matutino }\end{array}$ & $\begin{array}{l}\text { "O trabalho em grupo é uma oportunidade de construir coletivamente o } \\
\text { conhecimento e uma boa estratégia para o aprendizado. Relacionar a atividade } \\
\text { teórica em sala de aula com a prática do dia a dia é bom" }\end{array}$ \\
$\begin{array}{c}\text { Aluno F do Período } \\
\text { Noturno }\end{array}$ & $\begin{array}{c}\text { "A atividade ideal é aquela que o professor dá na sala de aula com o conteúdo } \\
\text { que ele está explicando" }\end{array}$ \\
Aluno G do Período & $\begin{array}{c}\text { "Atividades práticas, como na nossa área de Administração, fazer visitas técnicas, } \\
\text { como conhecer comércios e simular técnicas de compra e venda, vivenciar o } \\
\text { curso na prática é que se aprende o conteúdo" }\end{array}$ \\
Aluno H do Período & $\begin{array}{l}\text { "Exercícios, jogos entre os grupos e sendo matéria de administração tem que ter } \\
\text { atividades práticas que envolva como administrar um pequeno negócio desde o } \\
\text { primeiro módulo" }\end{array}$ \\
\hline
\end{tabular}

Fonte: Os autores (2018)

Como é possível averiguar através desses resultados, as dinâmicas de grupo são vistas como métodos pedagógicos proveitosos. De fato, nesses momentos em que os alunos se organizam em outra disposição física em sala de aula, surgem oportunidades de troca de ideias que não são plenamente possíveis quando o professor interpela a turma de modo generalizado, numa situação em que o aluno deve se expor mais. Dentro de grupos menores e na presença de colegas que "falam a sua língua", mesmo os mais tímidos conseguem expressar seus pensamentos e sensações. Outro dado que se destaca no Quadro 5 é uma particularidade dos cursos que, como o Técnico em Administração, requerem vivências práticas para a formação: visitar empresas, conhecer informações empíricas, estudar cases, estar lado a lado com administradores mais experientes são motivações importantes para os ainda aprendizes.

Quadro 6. Depoimentos dos professores sobre as atividades didáticas ideais

\begin{tabular}{cll} 
Professor C do & $\begin{array}{l}\text { "Entendo que a importância entre a vivência e a teoria são relevantes para o } \\
\text { aprendizado. Muitos fatores colaboram para que os momentos sejam bons: a } \\
\text { localização da escola, estrutura, organização, professores competentes, alunos } \\
\text { interessados" }\end{array}$ \\
\hline $\begin{array}{c}\text { Professor D do } \\
\text { Período Noturno }\end{array}$ & $\begin{array}{l}\text { "Procuro alcançar a realidade do aluno, adequando o tema do dia às suas } \\
\text { necessidades" }\end{array}$
\end{tabular}

Fonte: Os autores (2018)

Além, portanto, do reconhecimento da importância da prática relacionada à teoria, os professores destacaram outros fatores de sucesso escolar, apresentados no quadro acima, reforçando, então, a complexidade dessa questão. Um elemento que mereceu destaque foi justamente o relacionamento em sala de aula, entre os alunos e entre estes e os professores.

Quadro 7. Depoimentos dos alunos sobre problemas de relacionamentos em sala de aula

\begin{tabular}{|c|c|}
\hline $\begin{array}{l}\text { Aluno A do Período } \\
\text { Matutino }\end{array}$ & $\begin{array}{l}\text { "Sim. A professora gritou com o aluno, não aceitou seu erro gerando uma relação } \\
\text { difícil entre aluno-professor." }\end{array}$ \\
\hline $\begin{array}{l}\text { Aluno B do Período } \\
\text { Noturno }\end{array}$ & $\begin{array}{l}\text { "Sim, a respeito de um aluno não estar interessado na aula, e ficar fazendo o uso } \\
\text { do celular, o professor chamou a atenção do aluno e nada mudou. " }\end{array}$ \\
\hline $\begin{array}{l}\text { Aluno C do Período } \\
\text { Matutino }\end{array}$ & $\begin{array}{l}\text { "Sim, inclusive ocorreu na própria ETEC, o professor mal-educado se irritou com } \\
\text { perguntas sobre a matéria e acabou batendo mesas e cadeiras sem necessidade } \\
\text { alguma." }\end{array}$ \\
\hline $\begin{array}{l}\text { Aluno D do Período } \\
\text { Noturno }\end{array}$ & $\begin{array}{l}\text { "Sim, muitos problemas gravíssimos como falta de conteúdo, falta de aula, falta de } \\
\text { professor, falta de um bom coordenador, fala de uma direção mais competente, e } \\
\text { ainda assim nenhuma atitude foi tomada. " }\end{array}$ \\
\hline
\end{tabular}

Fonte: Os autores (2018) 
Quadro 8. Depoimentos dos professores sobre problemas de relacionamentos em sala de aula

\begin{tabular}{|ll} 
Professor A do & $\begin{array}{l}\text { "Diversas vezes: alunos com problemas familiares muitas vezes tentam mostrar } \\
\text { sua dor na escola. No meu caso, para cada situação uma solução: meninas } \\
\text { grávidas, conversei com os pais, diretora e conselho tutelar; meninos drogados, } \\
\text { solicitei ajuda psicológica da escola. " }\end{array}$ \\
& $\begin{array}{l}\text { "Sim. Com aula para adultos, já passei por situação de aluno embriagado e } \\
\text { algumas situações de desrespeito. O caso foi encaminhado para a coordenação, } \\
\text { que conversou em particular com a turma. A atitude da sala mudou e as aulas } \\
\text { passaram a fluir." }\end{array}$ \\
Professor B do &
\end{tabular}

Fonte: Os autores (2018)

Sabe-se que são inúmeros os problemas que podem surgir no convívio em ambiente escolar, por desavenças mais ou menos graves, com consequências mais ou menos sérias. Muitos professores admitiram não ter de enfrentar tantos desafios nesse sentido, assim como os alunos; entretanto, os poucos depoimentos em que foram relatados casos mais dramáticos servem para justificar a necessidade de auxílio profissional ao professor e ao aluno. É um tanto comum que os professores assumam a figura de psicólogos ou orientadores vocacionais, muitas vezes, quando do apelo de seus alunos; mas é válido destacar que o mais apropriado é um acompanhamento contínuo de um profissional com formação na área de especialização indicada. Os problemas vindos de fora ou de dentro da própria escola são, querendo ou não, vetores comportamentais que influenciam radicalmente o desempenho escolar.

Por isso, acredita-se que o projeto de extensão desenvolvido na ETEC Dona Escolástica Rosa, apesar de breve, surtiu efeitos duradouros em toda a comunidade. As aulas de Língua Portuguesa, Matemática Financeira e Gestão de Pessoas oferecidas aos sábados foram oportunidades de mobilizar alunos, professores, coordenadores e diretora para um mesmo fim, na tentativa de mudar um pouco a realidade da escola, o engajamento de seus atores ou mesmo o papel da instituição perante a comunidade externa. Ao final do curso, certificados para todos os envolvidos serviram não só de incentivo, mas de motivo de orgulho e autoestima. Nesse sentido, pode ser considerado um curso de extensão bem sucedido.

A iniciativa do corpo docente e discente fez com que a visão de todos sobre suas potencialidades mudasse. Ouvir alunos e professores e, ao mesmo tempo, vê-los participando de um projeto elaborado em conjunto, de forma colaborativa, permitiu vislumbrar novas perspectivas para a educação profissionalizante no Brasil.

\section{CONSIDERAÇÕES FINAIS}

Nesta investigação, o objetivo principal foi discutir quão importante é a gestão de projetos na educação técnica. Evidentemente, os ganhos poderiam também ser observados na educação em geral. Os resultados alcançados com a pesquisa bibliográfica e a pesquisa de campo, realizada na ETEC Dona Escolástica Rosa, em Santos (SP), mostraram que o cenário educacional tem realmente se alterado com a intensificação do uso de dispositivos móveis para comunicação e estudos formais, e que os alunos e os professores, em sala de aula, terão de juntos enfrentar o desafio de fazer com que esse dado seja motivador de práticas interessantes e profícuas. Além disso, os resultados também ressaltaram que os participantes todos da escola, inclusive os familiares, amigos e conhecidos dos alunos, cumprem papel fundamental na motivação que lhes despertam, dirimindo, assim, eventuais tentativas de evasão.

Foi possível concluir que a iniciativa de criação de projetos multidisciplinares é um diferencial nas instituições de ensino. A extensão é uma forma de integrar a sociedade e as áreas de mercado escolhidas pelo alunado no ensino técnico ao conteúdo programático dos cursos, constituindo-se também como interessante ocasião de captação de novos alunos.

Esta pesquisa pode servir como base para futuros estudos do mesmo tema, já que aponta para questões pertinentes à gestão de projetos em escolas profissionalizantes. Seu 
escopo e a amostra investigada poderiam ser ampliados. É necessária mais investigação

\section{REFERÊNCIAS}

[1]. BRASIL. Lei n. 9.394, de 20 de dez. de 1996. Lei de Diretrizes e Bases da Educação Nacional, Brasília, DF, dez. 1996. Disponível em: http://www. planalto.gov.br/Ccivil_03/leis/L9394.htm. Acesso em: 15 set. 2017

[2]. DAVIDSON, J. Iniciativa. Sessenta técnicas concretas para se motivar no trabalho. 1. ed. Campinas, SP: Editora Komedi, 2011.

[3]. DETREGIACHI FILHO, E. A evasão escolar na educação tecnológica: o embate entre as percepções subjetivas e objetivas. São Paulo: Cultura Acadêmica, 2012

[4]. FERNANDES, S.; FLORES, M. A.; LIMA, R. M. A aprendizagem baseada em projetos interdisciplinares no Ensino Superior: implicações ao nível do trabalho docente. International Simposium on Project approaches in engineering education. Universidade do Minho, Portugal, $p$. 227-236, 2012

[5]. INSTITUTO Unibanco. Aprendizagem em Foco. N.5, 2016. Disponível em: http://www.institutounibanco.org.br/aprendizagemem-foco/5/. Acesso em: 05 jul. 2017

[6]. KERZNER, H. Gestão de projetos: As melhores práticas. 3.ed. Porto Alegre, RS: Editora Bookman, 2017

[7]. KESLEY, R. Por que iniciativa vale mais que inteligência. Trace um plano de ação para sua vida. 1.ed. São Paulo, SP: Editora Gente, 2013. para determinar a eficácia desses projetos em diferentes instituições pelo país.

[8]. LEITE, L. H. A. Pedagogia de projetos: Intervenção no presente. Revista Presença pedagógica, v.2, no8., 1996.

[9]. INICIATIVA. Dicionário Michaelis Versão digital, 2018, s/p. Disponível em: http://michaelis.uol.com.br/modernoportugues/busca/portugues-brasileiro/iniciativa/. Acesso em: 25 ago. 2017

[10]. NELSON, B. 1001 Maneiras de tomar iniciativa no trabalho. 1.ed. Rio de Janeiro, RJ: Editora Sextante, 2008

NOBEL. Liderança: As regras do jogo. 1.ed. São Paulo, SP: Editora Nobel, 2007.

[12]. POLITY, E. Dificuldade de Ensinagem. São Paulo: Vetor Editora, 2002. PRENSKY, M. Digital Natives, Digital Immigrants. On the Horizon. MCB University Press, v. 9, n. 5, $2001 . \quad$ Disponivel em: http://www.marcprensky.com/writing. Acesso em: 01 ago. 2017

[13]. SAKAI, M. H.; LIMA, G.Z. PBL: uma visão geral do método. Olho Mágico, Londrina, v. 2, n. 5/6, n. esp., 1996.

[14]. THOMSON, J.C. PBL - uma proposta pedagógica. Olho Mágico, Londrina, v. 2, n. 3/4, 1996.

[15]. TUMAN, G. J. Development and implementation of effective project management information and control systems. In: CLELAND, D. I; KING, W. R. Project management handbook. New York: Van Nostrand Reinhold, 1983. 


\section{Capítulo 4}

\section{A REAL SITUAÇÃO DOS CARROS ELÉTRICOS E HIBRIDOS NA REGIÃO METROPOLITANA DO VALE DO PARAIBA E LITORAL NORTE}

\section{Natália Marcelino Ramos}

\section{Maurício Faria Nogueira}

\section{Antônio Wellington Sales Rios}

Resumo: Os carros movidos a combustíveis fósseis são considerados os maiores poluidores da atmosfera no Brasil e no mundo. Este estudo tem como objetivo, apresentar informações sobre os carros elétricos ou híbridos e a possível melhoria que estes veículos poderiam proporcionar a Região do Vale do Paraíba e Litoral Norte paulista se substituíssem os veículos convencionais. Foi realizada pesquisa Survey e através dos resultados obtidos foi feita uma análise da opinião dos moradores da região, quanto a substituição dos veículos convencionais por elétricos ou híbridos.

Palavras-chave: poluição atmosférica, carro elétrico, aquecimento global, chuva ácida. 


\section{INTRODUÇÃO}

Para satisfazer suas necessidades, antigamente, o homem deslocava-se apenas a pé. Com novas necessidades, as formas de deslocar-se evoluíram e foram utilizados animais, notadamente cavalos. Meios básicos foram surgindo para auxiliar em pequenas atividades do dia a dia, como construção de botes para atravessar rios e a utilização de animais, como força de tração.

Com a inovação e tecnologia, foi criado o motor a vapor e mais tarde o motor a combustão interna, que tem seu funcionamento a partir da queima controlada de ar e combustível na câmara de combustão, gerando energia e movendo com força e velocidade componentes do motor e rodas. Segundo Cabral (2013), o primeiro veículo a combustão foi criado e patenteado em 1886 por Karl Benz na Alemanha.

Foram apresentados no ano de 1800 os primeiros motores elétricos, porém, não é fácil atribuir a invenção do carro elétrico a apenas um inventor ou país. No início do século XIX foram criados os primeiros carros elétricos de pequena dimensão. De acordo com a especialista do departamento de energia dos EUA, Matulka (2014), o sistema híbrido foi inventado pelo americano Harry E. Dey em 1896, que combinava um motor a gasolina com um elétrico. Diferente dos carros a combustão, que utilizam a gasolina como fonte de energia e que é armazenada num reservatório de combustível, os carros elétricos têm sua fonte de energia armazenada em uma bateria (ARAÚJO, 2011).

Por volta de 1800, era possível escolher entre um carro a combustão ou elétrico. No entanto, os veículos movidos a gasolina apresentavam alguns problemas, como a necessidade de um grande esforço manual para serem dirigidos, eram muito barulhentos e possuíam um escape desagradável (MATULKA, 2014). Ao contrário dos carros a combustão, os elétricos não apresentavam nenhum destes problemas, eram silenciosos, fáceis de conduzir e não emitiam poluentes com mau cheiro. Com esta grande e vantajosa diferença, os carros elétricos se tornaram rapidamente os mais populares. Porém, com a invenção do automóvel da Ford os carros elétricos foram esquecidos.

Em 1997 a produção de carros híbridos ressurgiu com o modelo Prius da Toyota (OLIVEIRA, 2017) e em 2006 foi a vez da fabricante Tesla, com seu modelo 100\% elétrico (MOGNON, 2016). Desde então, os carros elétricos tentam novamente conseguir uma boa colocação entre os carros a combustão. Hoje, os consumidores tem mais opções quando se trata de adquirir um carro elétrico e com o crescente aumento nos preços dos combustíveis, os carros elétricos estão a ganhar cada vez mais popularidade.

Alguns países, como França, Reino Unido, Alemanha e Noruega já se preparam e fazem uma previsão para que entre os anos de 2025 e 2040 seja congelada a produção e importação de carros convencionais (PIZARRO, 2017).

Segundo Takahira (2017), diretor do núcleo de pesquisas da Associação Brasileira do Veículo Elétrico (ABVE), o Brasil está atrasado no mínimo cinco anos em relação ao mundo. A frota de carros elétricos e híbridos no Brasil é 20 vezes menor que a média mundial. Segundo a Federação Nacional da Distribuição de Veículos Automotores (Fenabrave), o número de carros elétricos ou híbridos vendidos no Brasil no ano de 2016 foi de 1.901, já o número de convencionais (não elétricos) vendidos no mesmo ano foi de 2,05 milhões. Foram vendidos 1.000 vezes mais veículos convencionais que elétricos ou híbridos em 2016.

A poluição matou 101.739 pessoas no Brasil em 2015, o que equivale a $7,49 \%$ do total de mortes no país durante o período, segundo relatório publicado pela revista científica The Lancet.

Segundo Vieira (2017) e com base em dados fornecidos pela Companhia Ambiental do Estado de São Paulo (CETESB) e o Instituto Saúde e Sustentabilidade constatou-se que moradores da Região Metropolitana do Vale do Paraíba e Litoral Norte (RMVPLN) aspiram $50 \%$ a mais de poluição no ar do que o recomendado pela Organização Mundial de Saúde (OMS).

A RMVPLN é a terceira região do Estado de São Paulo com o maior índice de poluição gerada e lançada na atmosfera, e este alto índice se deve a emissões veiculares segundo a Companhia Ambiental do Estado de São Paulo (CETESB, 2016). Uma solução para diminuição da poluição seria substituir a frota de veículos a combustão por carros elétricos ou híbridos.

Este trabalho tem como objetivo reunir informações e apresentá-las à sociedade e 
aos tomadores de decisão, sobre as vantagens dos carros elétricos, mostrando os principais modelos, marcas e desempenho, e os impactos ambientais destes veículos na RMVPLN.

\section{REVISÃO DA LITERATURA}

Este capítulo faz uma breve explanação sobre a poluição ambiental, enfatizando a poluição atmosférica, suas definições e consequências, assim como destacar os principais modelos e marcas de carros elétricos e híbridos, suas vantagens e desvantagens e o cenário brasileiro.

\subsection{POLUIÇÃO AMBIENTAL}

A poluição ambiental está atrelada a danos na saúde e no bem estar do homem, além dos ecossistemas. Nesse sentido Azuaga (2000) entende que a poluição do meio ambiente se caracteriza pela disposição indiscriminada de resíduos na água, no ar e no solo, impedindo a sua absorção ou reciclagem pelo próprio meio ambiente, que passa a arcar com seu efeito danoso, refletindo prejuízos no planeta.

A legislação brasileira (Lei n. 6.938 de 31 de agosto de 1981, Art. 3ํ, III) descreve como poluição a degradação da qualidade ambiental proveniente de atividades que direta ou indiretamente afetam a saúde, segurança e o bem estar da sociedade; criem condições adversas às atividades sociais e econômicas; afetem desfavoravelmente a biota; afetem as condições estéticas ou sanitárias do meio ambiente; lancem matérias ou energia em desacordo com os padrões ambientais estabelecidos.

\subsubsection{POLUIÇÃO ATMOSFÉRICA}

A saúde humana, os ecossistemas e os materiais têm sido afetados de diversas formas pela poluição do ar. Esse é um dos temas mais pesquisados nas últimas décadas. De acordo com Braga e Pereira (2001), a poluição do ar tem trazido consequências sérias para a saúde e convivência dos seres vivos, em especial do homem.

A poluição atmosférica pode ser vista de vários ângulos e as principais preocupações atuais relacionam-se a:
- Aquecimento global provocado por emissões de gases efeito estufa, principalmente dióxido de carbono (CO2) e metano (CH4), por veículos a combustão interna;

- Chuvas ácidas provocadas por emissões de gases (SOx e NOx) na queima de combustíveis fosseis por veículos a combustão interna;

- Inversões térmicas e SMOG (Smoke + Frog), também ocasionadas pelas emissões provenientes da queima de combustíveis fosseis.

Segundo o Departamento Nacional de Trânsito (DENATRAN, 1980), poluição atmosférica é entendida como uma mudança indesejável, e muitas vezes irreversível, nas características físicas, químicas ou biológicas do ar atmosférico, que pode afetar nocivamente o equilíbrio do sistema ecológico com interferência na vida do homem, animais e vegetais; deterioração dos bens culturais e de lazer; inutilização ou depreciação dos recursos naturais.

Os veículos automotivos e as indústrias presentes nos grandes centros urbanos são as principais fontes poluidoras do ar e segundo o Ministério de Meio Ambiente (2010), estudos revelam que um dos principais responsáveis pela emissão de gases de efeito estufa é o setor de transportes, e modal rodoviário é responsável por $90 \%$ das emissões. As fontes veiculares têm tido uma participação acentuada na degradação da qualidade do ar atmosférico (TEIXEIRA et al 2008).

Portanto, fica muito claro que as principais mazelas relacionadas à poluição atmosférica e suas consequências tem como o principal causador os veículos a combustão interna.

\subsection{PRINCIPAIS MODELOS E MARCAS DE CARROS ELÉTRICOS E HÍBRIDOS DISPONIVVEIS NO BRASIL}

Nos últimos dez anos, diversos modelos de carros elétricos e híbridos passaram a estar disponíveis no mercado, com autonomia cada vez maior. Espera-se que, no início da próxima década, a tecnologia dos carros evolua de forma que sua capacidade aumente e seu preço diminua - um dos principais fatores a serem superados para a comercialização do carro elétrico em grande escala. (DELGADO et al 2017). 
Entretanto, vários países do mundo vêm atuando proativamente para desenvolverem o carro elétrico e híbrido. Na Tabela 1 estão relatados os principais modelos, marcas e os preços comercializados no Brasil.

Tabela 1 - Modelos, marcas e preços de carros elétricos e híbridos comercializados em 2017 no Brasil.

\begin{tabular}{|c|c|c|}
\hline \multicolumn{3}{|c|}{ Modelos, Marcas e Preços - Carros Elétricos e Híbridos no Brasil } \\
\hline Modelo & Marca & Preço \\
\hline PRIUS (Híbrido) & TOYOTA & $\mathrm{R} \$ 123.950$ \\
\hline V60 (Híbrido) & VOLVO & $R \$ 136.950$ \\
\hline CT200H (Híbrido) & LEXUS & $\mathrm{R} \$ 149.900$ \\
\hline FUSION (Híbrido) & FORD & $\mathrm{R} \$ 149.900$ \\
\hline I3 (Elétrico) & BMW & $\mathrm{R} \$ 159.950$ \\
\hline LEAF (Elétrico) & NISSAN & $\mathrm{R} \$ 200.000$ \\
\hline OUTLANDER PHEV (Híbrido) & MITSUBISHI & $R \$ 204.990$ \\
\hline CAYENE PHEV (Híbrido) & PORSCHE & $\mathrm{R} \$ 430.000$ \\
\hline S400 (Híbrido) & MERCEDES BENZ & $\mathrm{R} \$ 430.000$ \\
\hline XC-90 T8 (Híbrido) & VOLVO & $\mathrm{R} \$ 456.950$ \\
\hline SERIE 7 (Híbrido) & BMW & $\mathrm{R} \$ 650.000$ \\
\hline MODEL S (Elétrico) & TESLA & $\mathrm{R} \$ 745.000$ \\
\hline MODEL X (Elétrico) & TESLA & $\mathrm{R} \$ 980.000$ \\
\hline
\end{tabular}

Fonte: Autores (2018).

\subsection{VANTAGENS E DESVANTAGENS DO USO DE CARROS ELÉTRICOS E HÍBRIDOS}

Com o avanço das montadoras na produção dos carros elétricos e híbridos e a possível implantação de incentivos do governo, vale ressaltar as principais vantagens $e$ desvantagens na utilização dos veículos:

\subsubsection{VANTAGENS}

- Meio Ambiente: não emitem poluentes, além de usar mais de $85 \%$ de material reciclado;

- Economia: combustível custa cinco vezes menos que a gasolina;

- Manutenção: custa cinco vezes menos que o veículo convencional;

- Conforto: é mais silencioso porque não tem motor a combustão;

- Segurança: peso e localização da bateria dão mais estabilidade em curvas:
- Torque: a força de arranque do veículo é maior que a dos carros convencionais.

\subsubsection{DESVANTAGENS}

- Autonomia: em média, 160 km, enquanto que um veículo convencional roda entre $400 \mathrm{~km}$ e 500 $\mathrm{km}$ antes de reabastecer;

- Tempo de recarga: veículo convencional gasta de 5 minutos a 10 minutos para encher o tanque $\mathrm{e}$ pagar, enquanto que 0 veículo elétrico precisa, no mínimo, de 30 minutos para recarregar;

- Local de abastecimento: por enquanto, só há três pontos de carregamento lento na capital;

- Preço do veículo: ainda é muito caro, se fosse vendido hoje custaria, em média, $\mathrm{R} \$$ 200.000. Pode ser atenuado com venda em escala; 
- Peso: apesar de o motor ter torque instantâneo, o desempenho é prejudicado pelo peso da bateria;

- Descarte da bateria: merece cuidados especiais por tratar-se de materiais tóxicos.

\subsection{COROLLA (TOYOTA) X BOLT (CHEVROLET)}

Comparativo do consumo entre o Toyota Corolla (combustão) e Chevrolet Bolt (100\% elétrico).

Tabela 2 - Comparativo de Consumo: Corolla (Toyota) X Bolt (Chevrolet).

\begin{tabular}{|c|c|c|c|c|c|c|c|}
\hline \multirow{2}{*}{ ANO } & MODELO & \multicolumn{2}{c}{ POTÊNCIA } & \multicolumn{2}{c}{ CONSUMO URBANO } & \multicolumn{2}{c}{ CONSUMO ESTRADA } \\
\hline 2018 & COROLLA & $139 \mathrm{cV}$ & - & $10 \mathrm{~km} / \mathrm{l}$ & - & $13 \mathrm{~km} / \mathrm{l}$ & - \\
\hline 2018 & BOLT & - & $202 \mathrm{cv}$ & - & $60 \mathrm{~km} / 60 \mathrm{kWh}$ & - & $60 \mathrm{~km} / 60 \mathrm{kWh}$ \\
\hline
\end{tabular}

Conforme Tabela 2, verifica-se que o modelo Bolt da Chevrolet é mais potente que o modelo Corolla da Toyota. Quanto ao gasto com consumo, o modelo elétrico fica um pouco atrás do motor a combustão $(7,5 \% \mathrm{em}$ custo).

O Corolla faz cerca de $10 \mathrm{~km} / \mathrm{l}$ de gasolina na cidade, considerando o preço da gasolina hoje $(R \$ 3,90)$, para percorrer $60 \mathrm{~km}$ precisaria de 6 litros de gasolina, ou seja, $R \$ 23,40$.

Para a mesma distância utilizada no exemplo acima, o modelo Bolt faz cerca de $60 \mathrm{~km}$ com uma carga de $60 \mathrm{kWh}$ na cidade e na estrada. De acordo com a calculadora on line da Eletropaulo, o custo aproximado seria de $\mathrm{R} \$ 25,16$ com impostos (por carga).

Com base nestes dados, conclui-se que para percorrer os mesmos $60 \mathrm{~km}$ o valor da recarga do carro elétrico fica apenas $R \$ 1,76$ $(7,5 \%)$ maior que o valor gasto com gasolina. Se levarmos em conta todos os benefícios e as externalidades que este veículo elétrico oferece, principalmente a preservação ambiental, a balança tende a pender para o modelo elétrico.

\subsection{CENÁRIO BRASILEIRO}

No Brasil o carro elétrico ainda é pouquíssimo conhecido e comercializado pela população. Não é fácil encontrar um argumento plausível para esse descaso. A falta de interesse dos governos em estimular esse limpo e econômico mercado de automóveis é nítida. Alega-se que a infraestrutura e os valores de comercialização são barreiras nesse processo, mas é difícil compreender por que outros países com matriz energética menos favorecida conseguiram introduzir o carro elétrico em seu modal de transporte.

Nos Estados Unidos, a General Motors anunciou em Detroit em outubro de 2017 que vai lançar globalmente pelo menos 20 carros elétricos nos próximos seis anos. Em dezembro de 2017 a empresa lançou um modelo nos Estados Unidos que vendeu 14,8 mil unidades em nove meses. O governo americano anunciou incentivos que reduziram o preço do carro elétrico Bolt para cerca de US\$ 30.000 .

Para o diretor de vendas da Volkswagen Wener Schaal, "a eletrificação dos veículos é um caminho sem volta e as questões estruturais precisam ser mais bem discutidas" (SODRE, 2017). Essa afirmação é corroborada quando se analisa os aspectos de eficiência e emissão de poluentes. Os motores elétricos são significativamente mais eficientes que os a combustão interna.

Considera-se que o rendimento de um motor do ciclo Otto com alimentação por gasolina é de, em média, 21 a 25\%, enquanto o rendimento de um motor do ciclo Diesel pode atingir 35\% (TILLMANN, 2013). Isso equivale a dizer que para cada 4 litros de gasolina que se queima em um motor a combustão interna ciclo Otto, 3 litros são desperdiçados.

Já os motores elétricos têm eficiência energética da ordem de 95\% com a adicional vantagem de não emitir gases poluentes.

O Bolt, carro elétrico produzido pela GM nos USA, tem autonomia para rodar $383 \mathrm{~km}$ com 
uma carga completa da bateria, que está instalada no assoalho, sem interferir no espaço para os cinco ocupantes. Numa tomada caseira de 240 volts leva 9 horas para uma carga completa. Em postos de recarga rápida são três horas, mas em uma hora é possível recarregar $80 \%$ da bateria. (SILVA,2017).

A Associação Brasileira do Veículo Elétrico relata que o novo regime automotivo em discussão o programa Rota 2030 deve abranger com mais propriedade o tema dos elétricos e híbridos. E a regulamentação do segmento de veículos híbridos e elétricos contribuirá para o desenvolvimento de infraestrutura (ABVE, 2017).

O novo programa Rota 2030 do governo brasileiro trata de um conjunto de regras que montadoras e importadoras deverão seguir englobando metas de eficiência de consumo de combustível, incentivo a pesquisa, segurança, entre outros itens (MIOTTO,2018).

Enquanto o governo demora em estabelecer as novas regras e incentivar as vendas de carros elétricos no Brasil, a população se resigna e aceita que a cada mês de atraso na adoção dessa tecnologia a poluição continue matando 8.500 brasileiros todo mês.

Pesquisas como a realizada por Accenture Strategy em parceria com a Fundação Getúlio Vargas (FGV) demonstraram que o mercado brasileiro tem potencial para vender $150 \mathrm{mil}$ unidades de carros elétricos por ano - cerca de $7 \%$ das vendas totais de automóveis em 2016 (REGHIN, 2018).

Segundo a FGV Energia, em 2017, foram vendidos apenas 3.296 híbridos e elétricos, número ainda insignificante diante dos 2.239 milhões comercializados, de acordo com a Associação Nacional dos Fabricantes de Veículos Automotores (ANFAVEA).

A barreira de preços se dá pelo fato que os elétricos e os híbridos são mais caros do que

Figura 1 - Questionário aplicado aos moradores sobre a utilização de carros elétricos ou híbridos. um veículo comum por causa da tecnologia empregada e também pela alta carga tributária.

"A redução dos preços para beneficiar a compra desse tipo de veículo precisa ser expressiva, e o governo brasileiro precisa entender que a mobilidade elétrica vai chegar", diz Ricardo Guggisberg, presidente da ABVE (Associação Brasileira do Veículo Elétrico).

\section{DESENVOLVIMENTO DA TEMÁTICA}

Para atingir os objetivos definidos, a pesquisa foi estruturada sobre três pilares: pesquisa bibliográfica, pesquisa participativa (moradores) e análise dos resultados obtidos.

A primeira etapa se refere a pesquisa bibliográfica, que une informações colhidas de artigos, livros e sites na internet em busca de embasamento teórico.

A segunda etapa trata-se de uma pesquisa realizada com moradores das cidades de São José dos Campos, Jacareí, Caçapava e Taubaté, onde foi apresentado um questionário contendo 10 perguntas relacionadas ao carro elétrico ou híbrido na RMVPLN. Para essa etapa foi utilizado o método survey.

Segundo Freitas et al. (2000), a pesquisa survey pode ser exposta como aquisição de dados ou informações sobre características, ações ou opiniões de delimitado grupo de pessoas, apontado como representador de uma população-alvo, através de um meio de pesquisa, que normalmente é um questionário.

Conforme Figura 1, a pesquisa foi realizada em janeiro do ano de 2018, com pessoas maiores de 18 anos e de diferentes classes econômicas, habilitadas ou não e que possuem ou não veículo próprio.

1. Você possui automóvel?

2. Você sabe o que é um carro a combustão?

3. Você sabe o que é um carro elétrico/híbrido?

4. Você sabe quanto custa um carro elétrico/híbrido?

5. Em sua opinião, os carros elétricos/híbridos substituirão os veículos comuns futuramente?

6. Se tivesse condições de adquirir ou substituir um carro a combustão por um carro elétrico/híbrido, o faria? Fonte: Autores. 
A terceira etapa da pesquisa foi destinada a analisar os resultados obtidos e apresentar dados que informe o quão informada está a população quando falamos de veículos sustentáveis e consequentemente o porque deste resultado.

\section{RESULTADOS E DISCUSSÃO}

Com base nas informações obtidas através da pesquisa, são apresentados os resultados na Tabela 3.

Tabela 3 - Resultado do questionário aplicado aos moradores das cidades de São José dos Campos, Jacareí, Caçapava e Taubaté.

\begin{tabular}{|c|c|c|c|c|c|c|}
\hline & Res & $\begin{array}{l}\text { s em } \\
\text { solut }\end{array}$ & neros & Respo & em Pc & ntagem \\
\hline & Sim & Não & $\begin{array}{l}\text { Não sei } \\
\text { dizer }\end{array}$ & Sim & Não & $\begin{array}{l}\text { Não sei } \\
\text { dizer }\end{array}$ \\
\hline 1. Você possui automóvel? & 23 & 77 & - & $23 \%$ & $77 \%$ & \\
\hline 2. Você sabe o que é um carro a combustão? & 38 & 62 & - & $38 \%$ & $62 \%$ & \\
\hline $\begin{array}{l}\text { 3. Você sabe o que é um carro } \\
\text { elétrico/híbrido? }\end{array}$ & 33 & 67 & - & $33 \%$ & $67 \%$ & \\
\hline $\begin{array}{l}\text { 4. Você sabe quanto custa um carro } \\
\text { elétrico/híbrido? }\end{array}$ & 28 & 72 & - & $28 \%$ & $72 \%$ & \\
\hline $\begin{array}{l}\text { 5. Em sua opinião, os carros } \\
\text { elétricos/híbridos substituirão os veículos } \\
\text { comuns futuramente? }\end{array}$ & 21 & - & 79 & $21 \%$ & - & $79 \%$ \\
\hline $\begin{array}{l}\text { 6. Se tivesse condições de adquirir ou } \\
\text { substituir um carro a combustão por um carro } \\
\text { elétrico/híbrido, o faria? }\end{array}$ & 28 & 72 & - & $28 \%$ & $72 \%$ & \\
\hline
\end{tabular}

Fonte: Autores.

Através da Tabela 3, foi possível observar que:

- $\quad 77 \%$ dos entrevistados não possui automóvel e 23\% possuem automóvel.

- $\quad 62 \%$ dos entrevistados não sabem o que é um veículo movido a combustão e 38\% tem conhecimento.

- $\quad 67 \%$ dos entrevistados não sabem o que são carros elétricos ou híbridos e 33\% tem conhecimento.

- $\quad 72 \%$ dos entrevistados não sabem quanto custa os carros elétricos ou híbridos e $28 \%$ sabem quanto custam.

- $\quad 79 \%$ dos entrevistados não sabem dizer se os carros elétricos ou híbridos substituirão os carros convencionais futuramente, enquanto $21 \%$ acreditam que sim.

- $\quad 72 \%$ dos entrevistados não adquiriam ou substituiriam os carros a combustão por carros elétricos ou híbridos, enquanto $28 \%$ fariam essa troca.

Através das respostas obtidas, é possível observar, que os carros elétricos ainda são poucos conhecidos na Região Metropolitana do Vale do Paraíba e Litoral Norte.
Segundo Pietro Erber (2013), diretorpresidente da ABVE (Associação Brasileira do Veículo Elétrico), a difusão de carros elétricos no Brasil ainda é inicial, mas promete boas expectativas.

De acordo com a Associação Nacional dos Fabricantes de Veículos Automotores (Anfavea), em 2017 foram vendidos cerca de 3.296 veículos híbridos e elétricos no Brasil, enquanto os veículos a combustão chegaram a 2.239 milhões de unidades vendidas. A quantidade de veículos elétricos e híbridos vendidos no ano passado é insignificante se comparada a comercialização de veículos a combustão no mesmo ano.

Segundo números do DETRAN, a quantidade de veículos elétricos e híbridos presentes na Região do Vale do Paraíba e Litoral Norte, representa menos de $1 \%$ da frota de carros na região. A cidade de Caraguatatuba conta com o maior número de automóveis elétricos e híbridos do vale.

Com base nas informações apresentadas, nota-se que o não conhecimento e o baixo volume de vendas de carro elétrico e híbrido, se dá pelo ao alto valor de comercialização e a falta de incentivos por parte do governo, como por exemplo os impostos cobrados para este tipo de veículo. 


\section{CONSIDERAÇÕES FINAIS}

Por fim, pode-se concluir desse estudo que a adoção de uma política que favoreça a troca de carros a combustão por carros elétricos está por demais e inexplicavelmente atrasada. Não faz sentido o Brasil continuar usando carros ineficientes e poluidores, colaborando com emissões de gases efeito estufa que provocam o aquecimento global e colaboram com as estatísticas de mortes de milhares de brasileiros por complicações

\section{REFERÊNCIAS}

[1]. ABVE - ASSOCIAÇÃO BRASILEIRA DO VEÍCULO ELÉTRICO. 2017. Disponível em http://www.abve.org.br/. Acesso em 30/01/2018.

[2]. ARAUJO, T. Revista Abril - Mundo Estranho - Como funciona o carro elétrico? 2011. Disponível em: https://mundoestranho.abril.com.br/tecnologia/com o-funciona-o-carro-eletrico/. Acesso em: 10/02/2018.

[3]. AZUAGA, D. Danos Ambientais causados por veículos leves no Brasil. 193 f. Dissertação (Mestrado em Ciências em Planejamento Energético) - UFRJ - Universidade Federal do Rio de Janeiro, 2000.

[4]. BRAGA, A. e PeReirA, L. A. A. Poluição atmosférica e saúde humana. Revista USP. n. 51, p. 58-71, Set.-Nov. 2001.

[5]. CABRAL, D.C Revista Abril - Mundo Estranho - Qual foi o primeiro carro a combustão? 2013. Disponível em: https://mundoestranho.abril.com.br/ tecnologia/qual-foi-o-primeiro- carro-a-combustao/. Acesso em: 10/02/2018.

[6]. Companhia Ambiental do Estado de São Paulo (CETESB) - Gazeta de Taubaté - Poluição: Região é a terceira do interior. 2016. Disponível em: https://gazetadetaubate.com.br/poluicaoregiao-e-a-terceira-do-interior/. Acesso em: 10/02/2018.

[7]. DELGADO, F.; FEBRARO, J.; SILVA, T. B. Caderno - FGV Energia Carros Elétricos. $20 \mathrm{f}$. Fundação Getúlio Vargas - FGV, Rio de Janeiro, 2017. Disponível em http://fgvenergia.fgv.br/publicacao/caderno-decarros-eletricos. Acesso em 07/03/2018.

[8]. DETRAN SP. Portal do Departamento de Trânsito de São Paulo. Disponível em: http://www.detran.sp.gov.br Acesso em: 15/02/2018

[9]. Departamento Estadual de Trânsito de São Paulo (DETRAN) Portal de notícias G1 - advindas da poluição provocada por veículos ultrapassados nos grandes centros urbanos.

Já passou da hora da sociedade brasileira exigir de seus representantes (governo) uma política séria, como tantos outros países tem adotado, de substituição de carros a combustão ultrapassados por carros elétricos que, conforme mostramos, são muito mais eficientes do ponto de vista energético e não poluem.

Veículos elétricos representam menos que 1\% da frota de carros na região. 2017. Disponível em: https://g1.globo.com/sp/vale-do-paraibaregiao/noticia/veiculos-eletricos-representammenos-que-1-da-frota-de-carros-na-regiao.ghtml. Acesso em: 10/02/2018.

[10]. ELETROPAULO Simulador. Disponível em: https://www.aeseletropaulo.com.br/educacaolegislacao-seguranca/simuladores/paginas/calculesua-conta.aspx. Acesso em: 10/03/2018.

[11]. EBER, P. - Popularização do carro elétrico no Brasil esbarra em IPI de 25\%. 2013. Disponível em:

https://www.terra.com.br/noticias/ciencia/populariz acao-do-carro-eletrico-no-brasil-esbarra-em-ipi-de25,b3237ce907a6e310VgnCLD2000000ec6eb0aR CRD.html. Acesso em: 10/02/2018.

[12]. FGV ENERGIA. Brasil tem potencial para vender 150 mil carros elétricos ao ano. 2018. Disponível em http://fgvenergia.fgv.br/noticias/brasil-tempotencial-para-vender-150-mil-carros-eletricos-aoano. Acesso em 02/04/2018.

[13]. LEI № 6.938, DE 31 DE AGOSTO DE 1981. Política Nacional do Meio Ambiente. Disponível em http://www.planalto.gov.br/ccivil_03/leis/l6938.htm. Acesso em: 08/02/2018.

[14]. MATULKA, R. Departamento de Energia dos EUA - The History of the Eletric Car. 2014. Disponível em: https://www.energy.gov/articles/history-electric-car. Acesso em: 10/02/2018.

[15]. MINISTERIO DO MEIO AMBIENTE. Emissões Veiculares. 2010. Disponível em http://www.mma.gov.br/mma-em-

numeros/emissoes-veiculares. Acesso em 20/02/2018

[16]. MIOTTO, R. Jornal da Globo - Rota 2030, novo regime automotivo, sai nos próximos dias, diz ministro. 2018. Disponível em: 
https://g1.globo.com/carros/noticia/rota-2030-novoregime-automotivo-sai-nos-proximos-dias-dizministro.ghtml. Acesso em: 28/02/2018.

[17]. MOGNON, M. Adreline - Tesla: Conheça a fabricante de carros elétricos de Elon Musk. 2016. Disponível em: https://adrenaline.uol.com.br/2016/10/28/45059/tes| a-conheca-a-fabricante-de-carros-eletricos-deelon-musk/. Acesso em: 10/02/2018.

[18]. OlIVEIRA, R. Notícias automotivas Toyota Prius se tornou o primeiro híbrido para as massas há 20 anos. 2017. Disponível em: https://www.noticiasautomotivas.com.br/toyotaprius-se-tornou-o-primeiro-hibrido-para-as-massasha-20-anos/. Acesso em: 10/02/2018.

[19]. PINSONNEAUT, A. \& KRAEMER, K. L. Survey research in management information systems: an assessement. Journal of Management Information System, 1993.

[20]. PIZARRO, L. Jornal O tempo - Mundo tem meta para o fim do carro a combustão, Brasil não. $2017 . \quad$ Disponível em: http://www.otempo.com.br/capa/economia/mundotem-meta-para-o-fim-do-carro-acombust\%C3\%A3o-brasil-n\%C3\%A3o-1.1508156. Acesso em: 10/02/2018.

[21]. REGHIN, M. Brasil tem potencial para vender 150 mil carros elétricos ao ano. Revista Época Negócios, 2018. Disponível em: https://epocanegocios.globo.com/Tecnologia/notici a/2018/02/brasil-tem-potencial-para-vender-150-

mil-carros-eletricos-ao-ano.html. Acesso em: 05/03/2018.

[22]. Revista The Lancet - Poluição mata mais de 1000 mil pessoas por ano no Brasil. 2017. Disponível http://www.bbc.com/portuguese/geral-41692503. Acesso em: 13/03/2018.

[23]. SILVA, C. Jornal O Estado de São Paulo GM testa carro elétrico Bolt EV no Brasil. Disponível em:

http://economia.estadao.com.br/noticias/geral,gmtesta-carro-eletrico-bolt-ev-no-brasil,70002028065. Acesso em: 26/02/2018.

[24]. SODRÉ, E. Folha de São Paulo - Avanço dos carros elétricos no país esbarra em falta de infraestrutura. Disponível em: http://www1.folha.uol.com.br/mercado/2017/12/194 3827-avanco-dos-carros-eletricos-no-pais-esbarraem-falta-de-infraestrutura.shtml. Acesso em: 26/02/2018.

[25]. TEIXEIRA, E. C; FELTES, S; SANTANA, E. R. R. Estudo Das Emissões De Fontes Móveis $\mathrm{Na}$ Região Metropolitana De Porto Alegre, Rio Grande Do Sul. Química Nova, Vol. 31, pag 244, 2008.

[26]. TILLMANN, C. A. C. Motores de Combustão Interna e seus Sistemas. 165 f. Instituto Federal de Educação, Ciência e Tecnologia Sul-riograndense, Pelotas, RS, 2013.

[27]. TRIGUEIRO, A. e KOVALICK R. Jornal da Globo - Utilização de carros elétricos cresce lentamente no Brasil. 2013. Disponível em: http://g1.globo.com/jornal-daglobo/noticia/2013/02/utilizacao-de-carroseletricos-cresce-lentamente-no-brasil.html. Acesso em: 10/02/2018.

[28]. VIEIRA, C. Jornal O Vale - Vale tem 50\% mais poluição no ar do que máximo recomendado. 2017. Disponível em: http://www2.ovale.com.br/vale-tem-50-mais-poluico-no-ar-do-que-maximo-recomendado-1.749444. Acesso em: 10/02/2017. 


\section{Capítulo 5}

\section{ANÁLISE DA INFLUÊNCIA DA OBRIGATORIEDADE DA RASTREABILIDADE DE MEDICAMENTOS SEGUNDO A RDC $157 / 2017$}

\section{Lucas Santana Freires}

Jessicamaki Hirakawa Terra

Maick Roberto Lopes

Resumo: Visando evitar o roubo, extravio e a venda ilegal de medicamentos, a nova lei RDC 157/2017 obriga que todos os medicamentos até o ano de 2022 possuam o código de rastreio bidimensional 2D -Datamatrix. O objetivo geral do estudoé analisar a influência da obrigação da rastreabilidade de medicamentos na cadeia de distribuição. A metodologia utilizada foi a pesquisa bibliográfica de cunho exploratório-descritivo, com análise qualitativa de dados. Tendo em vista identificar e relacionar as ações adotadas pelas indústrias farmacêuticas, as empresas que prestam o serviço de rastreamento e os varejistas juntamente com o consumidor final, foi realizado um levantamento com empresas onde as entrevistadas acreditam na garantia da integridade final dos produtos, e na diminuição da sonegação fiscal.

Palavras-chave: Rastreabilidade. Mercado Fármaco. Medicamentos. 


\section{INTRODUÇÃO}

$\mathrm{Na}$ atualidade, a economia mundial está em constante crescimento. Após a última grande crise financeira, ocorrida em 2016, o FMl (Fundo Monetário Internacional) apresentou dados demonstrando um aumento de 3,6\%, na economia global, ainda que haja crises pontuais em diversas localidades ao redor do mundo. Não obstante a essas crises no âmbito político e financeiro, as empresas vêm se desenvolvendo a cada dia e apresentando melhoras tecnológicas, com o propósito de se tornarem mais competitivas e então, fortalecer o mercado.

Um mercado altamente competitivo e que demonstra constante crescimento nos últimos 10 anos, é a indústria de produtos fármacos. No ano de 2014, este segmento teve umavanço de $11,4 \%$ em relação ao ano anterior. Deste avanço, os mercados emergentes representam um total de $25 \%$ do todo; de acordo com dados do IMS Health (2016) retratado pela Interfarma, o Brasil ocupa a sétima posição neste segmento com crescimento de $13,1 \%$ movimentando $\mathrm{R} \$ 50$ bilhões anuais no ano de 2016.

Os principais problemas encontrados neste setor, são o roubo e o extravio de cargas, já que os produtos transportados são bastantevisados para roubo, onde no ano de 2011 segundo levantamento SETCESP/FETCESP houve no período de janeiro a dezembro deste mesmo ano, 518 ocorrências relacionadas a roubo de carga no estado de São Paulo, sendo a quarta maior ocorrência de roubos no período; este total de ocorrências acarretou ao total de 24,781 milhões de reais, sendo também o quarto maior do estado e representando $8,38 \%$ do montante extraviado, assim acarretando enormes prejuízos ao consumidor final, às empresas e ao governo através da menor arrecadação de impostos.

Uma das formas de se evitar este prejuízo, é a utilização da rastreabilidade, empregada tanto na prevençãodo desvio da carga quanto para permitir uma rápida identificação e recolhimento de lotes com possíveis desvios na qualidade. Sem o rastreamento, atualmente é impossível saber a destinação precisa de cada caixa de medicamento.

Com o intuito da amenização e futura dissolução deste problema, aAnvisa (Agência Nacional de Vigilância Sanitária) publicou uma Resolução da Diretoria Colegiada (RDC) sobre o rastreamento e monitoramento de medicaçõessob o número RDC 157/2017. Esta resolução tem como objetivo principal evitar o roubo, extravio e a venda ilegal de medicamentos; para tanto, a RDC 157/2017, obriga que todos os medicamentos até o ano de 2022 possuam o código de rastreio bidimensional 2D - Datamatrix (QR CODE), que congrega todas as informações relativas a ele, como: lote, validade, número de série e de registro na Anvisa, além do histórico e trajetória do produto: centro de distribuição, distribuidores, farmácias e drogarias até chegar ao consumidor final.

Esta nova regulamentação irá impactar diretamente em toda cadeia de fornecimento de medicamentos, incluindo a obrigatoriedade do controle e da rastreabilidade destes produtos. Neste contexto, o objetivo deste artigo é analisar a influência da obrigação da rastreabilidade de medicamentos na cadeia de distribuição. Para se alcançar este intuito, foi realizada uma pesquisa bibliográfica.

Por fim, estão presentes as considerações finais, as principais análises e conclusões.

\section{EMBASAMENTO TEÓRICO}

A preocupação sucessiva com a segurança na movimentação e na venda aos consumidores de produtos farmacêuticos, por parte de autoridades públicas e das indústrias, incentivou $\mathrm{o}$ acolhimento de sistemas de rastreabilidade neste fragmento do mercado.

\subsection{RASTREABILIDADE}

O conceito de rastreabilidade surgiu devido a necessidade de saber a localizaçãode um produto cujo qual se encontra na cadeia logística.

A obra Juran'sQualityHandbook, define a rastreabilidade como sendo:

"Capacidade de rastrear o histórico, aplicação ou localização de uma entidade por meio de identificações gravadas" (JURAN, 1998-1590 p.). Nesta mesma obra,a rastreabilidade é associada a uma ferramenta do gerenciamento da qualidade.

Segundo definição do Guia de Termos e Expressões desenvolvido pela ABNT juntamente com o Sebrae, a rastreabilidade é 
definida como sendo a "Propriedade do resultado de uma medição ou do valor de um padrão relacionado a referências estabelecidas, geralmente a padrões nacionais ou internacionais, por meio de uma cadeia contínua de comparações, todas tendo incertezas estabelecidas." (ABNT, 2012-19 p.)

Já a ABNT NBR ISO 9000/2015 a rastreabilidade é definida como sendo: "a habilidade de rastrear o histórico, aplicação ou localização de um objeto. Ao considerar um produto ou serviço, rastreabilidade pode se referir a:

- $\quad$ Origem dos materiais e das peças;

- Histórico do processamento do produto;

- Distribuição e localização do produto depois da entrega."(ABNT NBR ISO 9000/2015 3.6.13, p.70)

Para ANVISA, a rastreabilidade é o "conjunto de mecanismos e procedimentos que permitem traçar o histórico, a custódia atual ou a última destinação conhecida de medicamentos" (RDC 157/2017, 2017).

A realização de procedimentos de rastreabilidade depende, fundamentalmente dasfacilidades de acesso a processos produtivos ao longo da cadeia, desde o início, passando pelas unidades de processamento, até os diversospontos de distribuição e consumo.

\subsection{BENEFÍCIOS DA RASTREABILIDADE}

A alta concorrência e premissas em relação à confiabilidade e qualidade dos serviços e produtos apresentados, os sistemas de rastreamento tornaram-se essenciais para aprimorar a produtividade e eficácia das empresas.

O rastreamento de uma cadeia produtiva conjectura relação entre distintos segmentos desta cadeia, ao passo que, o rastreamento interno atribui-se a apenas um segmento. Dessa maneira, consoante Vinholis e Azevedo
(2002) a rastreabilidade interna constitui uma ferramenta de controle de processos internos, objetivando sobretudo a redução de custos, falhas e perdas. A rastreabilidade da cadeia, por sua vez, adiciona aspectos relativos à diferenciação de produtos e identificação de responsáveis.

A delimitação do grau de rastreabilidade o qual pretende-se acolher, submete-se a uma variável importante: o custo de implantação e execução do processo. Na ocorrência de alguma inconformidade, este custo está atrelado à perquirição nos processos, cognição dos componentes da mercadoria em múltiplas etapas do processo de acabamento, avaliação crítica dos registros e a reavaliação dos documentos de registro de expedição e locação de produtos com não conformidades, conforme esclareceu Vinholis e Azevedo (2002).

Lombardi (1998) afirma que, no que tange à questão da segurança, uma garantia oferecida ao cliente de que está adquirindo uma mercadoria que é fiscalizada em todas suas etapas, é através do uso da rastreabilidade. Ela torna-se um dispositivo cada vez mais relevante, pois decorre da crescente preocupação com qualidade e segurança e é a base para a instituição de uma programação de qualidade numa cadeia em sua totalidade.

\subsection{CADEIA DE ABASTECIMENTO}

Segundo Bertaglia (2013) a cadeia de Abastecimento, "corresponde ao conjunto de processos requeridos para obter materiais, agregar-Ihes valor de acordo com a concepção dos clientes e consumidores e disponibilizar os produtos para o lugar (onde) e para a data (quando) que o cliente $e$ consumidores os desejarem".

\subsubsection{FORMAÇÃO DA FARMAUCÊUTICA NO BRASIL}

CADEIA

A cronologia de eventos relevantes no Brasil para a formação da cadeia farmacêutica dáse através de diversos eventos demonstrados através da figura 1.1. 
Figura 1.1 - Cronologia da formação da cadeia farmacêutica brasileira.

\begin{tabular}{|c|c|c|c|c|c|c|}
\hline $\begin{array}{l}\text { Década de } \\
30\end{array}$ & $\begin{array}{l}\text { Década de } \\
50\end{array}$ & 1971 & 1974 & $\begin{array}{l}\text { Década de } \\
80\end{array}$ & $\begin{array}{l}\text { Década de } \\
90\end{array}$ & 1999 \\
\hline $\begin{array}{c}\text { - Formação } \\
\text { das } \\
\text { primeiras } \\
\text { empresas } \\
\text { farmacêutic } \\
\text { as } \\
\text { brasileiras } \\
\text { com } \\
\text { característi } \\
\text { cas } \\
\text { industriais, } \\
\text { a partir das } \\
\text { boticas; }\end{array}$ & $\begin{array}{c}\text { - Internacion } \\
\text { alização da } \\
\text { indústria, } \\
\text { com as } \\
\text { políticas de } \\
\text { atração das } \\
\text { primeiras } \\
\text { empresas } \\
\text { multinacion } \\
\text { ais; }\end{array}$ & $\begin{array}{c}\text { - Promulgação do } \\
\text { Código de } \\
\text { Propriedade } \\
\text { Industrial pela } \\
\text { Lei 5.772, de } \\
21.12 .1971 \text {, que } \\
\text { não reconhecia } \\
\text { patentes nem de } \\
\text { produtos } \\
\text { químicos nem } \\
\text { de processos de } \\
\text { obtenção, e } \\
\text { criaçấo da } \\
\text { Central de } \\
\text { Medicamentos } \\
\text { (Ceme), órgão } \\
\text { do Ministério da } \\
\text { Saúde } \\
\text { encarregado de } \\
\text { definir as } \\
\text { políticas e } \\
\text { centralizar as } \\
\text { compras } \\
\text { governamentais } \\
\text { de } \\
\text { medicamentos; }\end{array}$ & $\begin{array}{c}\text { • Elaboração } \\
\text { da primeira } \\
\text { Relação } \\
\text { Nacional } \\
\text { de } \\
\text { Medicame } \\
\text { ntos } \\
\text { Essenciais } \\
\text { (Rename), } \\
\text { atualizada } \\
\text { em } 1999 \\
\text { pela } \\
\text { Portaria } \\
\text { MS 597/99 } \\
\end{array}$ & $\begin{array}{c}\text { - Medidas } \\
\text { diversas de } \\
\text { controle de } \\
\text { preços de } \\
\text { medicamento } \\
\text { s; } \\
\text { '1984 - } \\
\text { Portaria } \\
\text { Interministeria } \\
\text { In } \text { no, dos }^{\circ} \text { dos } \\
\text { Ministérios da } \\
\text { Saúde e da } \\
\text { Indústria e } \\
\text { Comércio, } \\
\text { que } \\
\text { estabeleceu } \\
\text { medidas de } \\
\text { incentivo e } \\
\text { proteção à } \\
\text { produçãao } \\
\text { interna de } \\
\text { fármacos; }\end{array}$ & $\begin{array}{c}\text {-1990 - Redução } \\
\text { das tarifas de } \\
\text { importação de } \\
\text { fármacos e } \\
\text { medicamentos e } \\
\text { eliminaçãoo das } \\
\text { restriçōes e } \\
\text { proibiçôes à } \\
\text { importação de } \\
\text { insumos } \\
\text { farmacêuticos; } \\
\text {-1991 à 1999- } \\
\text { Liberaçăo dos } \\
\text { preços de } \\
\text { medicamentos; } \\
\text {-1996 - } \\
\text { Promulgação da } \\
\text { Lei de Patentes } \\
\text { no Brasil; } \\
\text {-1998 - Portaria } \\
\text { MS 3.916/98, } \\
\text { estabelecendo a } \\
\text { Política } \\
\text { Nacional de } \\
\text { Medicamentos; }\end{array}$ & $\begin{array}{c}\text { - Promulgação } \\
\text { da Lei de } \\
\text { Genéricos, } \\
\text { criação da } \\
\text { Agência } \\
\text { Nacional de } \\
\text { Vigilância } \\
\text { Sanitária } \\
\text { (Anvisa) e } \\
\text { retomada da } \\
\text { política de } \\
\text { administraçã } \\
\text { o de preços } \\
\text { de } \\
\text { medicament } \\
\text { os }\end{array}$ \\
\hline
\end{tabular}

Fonte: Adaptada de BNDES (2003)

\subsubsection{CADEIA FARMAUCÊUTICA NO BRASIL}

A sua cadeia do setor farmacêutico apresenta diversos membros que vão desde os fornecedores de matérias primasmais básicas, passando por laboratórios e órgãos da esfera estadual e federal, e os grandes distribuidores e varejistas até a chegada dos produtos aos consumidores finais.

\subsection{O MERCADO FARMACÊUTICO}

Esta cadeia utiliza-se da transformação de substâncias químicas e vegetais em princípios ativos, identificados como farmoquímicos, os quais são transformados em fármacos, para o tratamento. Do mesmo modo é possível a consecução de medicamentos pelo meio biotecnológico. Esta é uma alternativa que vem se destacandomundialmente no meio deste mercado e substituindo o método utilizado no desenvolvimento de novas técnicas de síntese química.

Segundo levantamento do IPEA (Instituto de Pesquisa Econômica Aplicada) (Magalhães et al., 2003), a competição no meio dos grandes laboratórios teve um grande crescimento na década de 90 em decorrência dos custos progressivos em pesquisas e inovação para este mercado, e do avanço dos fármacos genéricos. Estas decorrências aconteceram juntamente à ampliação dos mecanismos públicos e privados de coordenação desta indústria com objetivo de reduzir custos de produtos fármacos.

Diversos acontecimentos impactaram a idiossincrasia do setor, entre as quais estão a desvalorização do câmbio da moeda, com impacto nas importações e em consequência do aumento nos custos e a introdução de fármacos genéricos nos anos 2000 originando um novo fragmento do mercado no Brasil, com paradigmas de concorrência completamente diferentes do realizado pela fração conhecida como "drogas de marca".

Segundo a Federação Brasileira da Indústria Farmacêutica (Febrafarma), em 2003 o mercado farmacêutico brasileiro ocupava a $11^{\text {a }}$ posição no ranking do mercado farmacêutico mundial (varejo farmacêutico), com 1, 498 bilhão de unidades (caixas) vendidas, $7,2 \%$ inferior em relação a 2002, e valor nominal de vendas de $\mathrm{R} \$ 16,9$ bilhões. Já em 2004 o Brasil conquistou a $8^{\underline{a}}$ posição no mercado farmacêutico mundial, apresentando um faturamento de $\mathrm{R} \$ 19,9$ bilhões, o que correspondeu à venda de 1,65 bilhão de unidades. Em 2005, o Brasil caiu para a $10^{a}$ posição no mercado farmacêutico mundial, com um faturamento de $R \$ 22,2$ bilhões, equivalente à venda de 1,61 bilhão de unidades. 


\section{DESENVOLVIMENTO DA TEMÁTICA}

Essa pesquisa é definida como exploratória ou descritiva, na medida em que procura esclarecer conceitos, definir problemas e descrever comportamentos dos agentes envolvidos no processo de rastreabilidade de medicamento (GIL, 2000). Os meios utilizados para a realização foi a pesquisa bibliográfica.

No desenvolvimento deste trabalho utilizouse uma abordagem qualitativa, direcionada mais para a compreensão dos fatos do que na mensuração de fenômenos, promovendo dessa forma, o entendimento do problema (YIN, 1994).

Entre os diversos tipos de pesquisa qualitativa, o método de estudo de caso foi considerado o mais adequado, pois possibilita a utilização de várias fontes de evidência, permitindo aprofundar os conhecimentos sobre uma determinada realidade (TRIVIÑOS, 1990).

Um estudo caracteriza-se como descritivo quando o pesquisador levanta dados de forma sistemática e padronizada, pois, tem como objetivo analisar características e costumes como forma de descrever o objeto de estudo e mostrar sua influência no contexto da pesquisa (GIL, 2012).

Ainda de acordo com Gil (2012), a pesquisa bibliográfica é a coleta de informações por meio de materiais já elaborados, usadas para explorar os temas do estudo sem a necessidade de pesquisa de campo. As informações podem ser extraídas de várias fontes, como de livros, enciclopédias e almanaques, publicações periódicas como jornais e revistas, dentre outras.

\section{RESULTADOS E DISCUSSÃO}

De modo a identificar e relacionar as ações adotadas pelas indústrias farmacêuticas, as empresas que prestam o serviço de rastreamento e os varejistas juntamente com o consumidor final, foi realizado um levantamento de tais empresas, cujo as quais não terão seus nomes reais revelados, sobre quais os procedimentos que estão sendo adotados e os quais as empresas podem oferecer.

Desta maneira, como já exposto na seção 3 , utilizaremos os dados de expostos sobre rastreabilidade, para acesso público, de uma indústria farmacêutica, uma empresa que prestam o serviço referido (terceirizadas) e uma farmácia.

\subsection{INTERVENÇÕES ADOTADAS PARA A ADEQUAÇÃO DA NECESSIDADE DA RASTREABILIDADE NA INDUSTRIA FARMACÊUTICA "G"}

O laboratório "G" já se adequava para as necessidades futuras com relação a rastreabilidade, para já estar devidamente instalado e em funcionamento. Inicialmente, a empresa avaliou que seria preciso investir entre $R \$ 4$ milhões e $R \$ 5$ milhões para adequações. Agora, a companhia estima que serão necessários mais de $\mathrm{R} \$ 20$ milhões. $\mathrm{O}$ montante não diz respeito somente às mais de 30 linhas de produção, mas também a etapas da distribuição dos produtos.

A opinião apresentada pelo diretor do centro de serviços compartilhados da empresa "G", "a exigência do rastreamento é legítima e oportuna porque, entre outros efeitos, garantirá a integridade final dos produtos e tornará mais difícil a sonegação fiscal, o que deixará a concorrência no setor mais justa".

Todavia, ele identificava dois problemas que foram sanados pela RDC 157/2017, que eram no modo como a implantação, previamente, estava sendo conduzida. O primeiro foi a demora da Agência Nacional de Vigilância Sanitária (Anvisa) em estabelecer tecnologias a serem utilizadas. De acordo com ele, era preciso estabelecer o modelo da base de dados que armazenará as informações sobre os medicamentos, onde essa base ficará hospedada, qual entidade fará a gestão das informações coletadas, qual tecnologia de transmissão de dados deverá ser utilizada e com qual periodicidade o banco de dados precisa ser atualizado, entre outras coisas. Os quais foram sanadas com esta Resolução da Diretoria Colegiada.

O outro impasse é o prazo que os laboratórios receberam para implementar a mudança. "É praticamente impossível colocar esse ambiente em operação em toda a indústria no prazo em que a lei prevê", diz o diretor.

Para o diretor industrial do "G", os eventuais ganhos que a rastreabilidade poderá gerar, como redução do roubo de cargas e no valor do seguro, não compensarão os investimentos. "Os ganhos são indiretos, não diretos", diz. 


\subsection{SERVIÇO PRESTADO PELA EMPRESA FORNECEDORA DO SERVIÇO "N"}

A Empresa "N" fornece todo o conjunto de hardware e software parar a implantação da rastreabilidade de medicamentos, conforme RDC 157 de 2017, publicada pela Anvisa. O sistema possui um software de rastreabilidade de medicamentos, com o objetivo de fazer a interface entre o ERP, linhas de produção, depósito, stakeholders e Anvisa.

Fornecimento de equipamento, como a estação de serialização, com o objetivo de imprimir a codificação 2D, tipo Datamatrix e dados variáveis em cartuchos, verificar a impressão por uma câmera e rejeitar o produto, em caso de não conformidade. Todas as informações de produção, rejeição de produto e número de série, serão gerenciadas pelo software do equipamento que serialização poderá vir equipado com balança dinâmica, aplicadora de selo de segurança, viradores, entre outros opcionais.

A Empresa fornece 0 software de rastreabilidade de medicamento que já foi instalado em diversas indústrias na Turquia, Europa e Ásia.O software é responsável por toda a comunicação externa e interna, referente aos dados da rastreabilidade de medicamentos.

\subsection{MEDIDAS ADOTADAS PELA FARMACIA "S"}

Para aprimorar a segurança do paciente, a instituição iniciou o projeto de rastreabilidade intra-hospitalar. Cujo a qual tinham objetivo de monitorar o recebimento, distribuiçãoe administração dos medicamentos, mantendo o controle sobre lote e validade dos medicamentos.

Anteriormente a regulamentação imposta pela Anvisa não existia viabilidade de se realizar a rastreabilidade, pois os medicamentos entregues pelos fabricantes não possuíam os requisitos mínimos para o controle. A maioria dos fornecedores não disponibilizava medicamentos em embalagens identificadas adequadamente.Em se tratando de dispensação hospitalar, é imperativo que a identificação completa seja realizada na embalagem primária.

Para se contornar este problema antes da regulamentação, a alternativa adotada estava na re-etiquetagem dos medicamentos em todos os tipos de apresentação e formas farmacêuticas.
Com o código bidimensional DATAMATRIX, de conteúdo variável deixou-se de ter a necessidade de re-etiquetagem de todos os produtos e passaram a ter o processo de recebimento com maior segurança na embalagem original.

\section{CONSIDERAÇÕES FINAIS}

Conforme mencionado na literatura, o objetivo inicial do projeto foi analisar a influência da obrigação da rastreabilidade de medicamentos na cadeia de distribuição. A primeira pergunta neste estudo procurou determinar os benefícios oferecidos pela rastreabilidade em relação a segurança e confiabilidade para as empresas, fornecedores, e o consumidor final.

Ainda há muitas perguntas sem resposta com relação aos custos de aplicação, logo, novas pesquisas devem ser realizadas para investigar os eventuaisganhos que não suprem o alto valor de investimento que a rastreabilidade requer. Sugere-se, portanto, um estudo mais aprofundado com mais foco no capital de giro.

Nesta investigação, o objetivo principal do presente estudo foi identificar e relacionar as ações adotadas pelas indústrias farmacêuticas, as empresas que prestam o serviço de rastreamento e os varejistas juntamente com o consumidor final.Retornando para a hipótese/pergunta feita no início deste estudo, agora é possível afirmar que os principais benefícios são a segurança e a confiabilidade entre cliente e empresa.

Os resultados deste estudo indicam que as empresas acreditam na garantia da integridade final dos produtos, e na diminuição da sonegação fiscal. Uma implicação disso é a possibilidade da utilização de um software de rastreabilidade que é responsável por toda a comunicação externa e interna.

Esta pesquisa amplia nosso conhecimento quando falamos em um alto nível de serviço pela garantia de segurança durante o transporte. Servirá como base para futuros estudos com maior aprofundamento sobre o capital de giro e o valor investido.

Uma limitação deste estudo foi a carência de dados e referências com relação a legislação, por ser recente e não possuir número considerável de estudos realizados; além dos 
dados relacionados às operações internas que as indústrias não disponibilizam. É necessária mais investigação para determinar a eficácia da rastreabilidade no segmento

\section{REFERÊNCIAS}

[1]. ABNT, Associação Brasileira de Normas Técnicas; SEBRAE, Serviço Brasileiro de Apoio às Micro e Pequenas Empresas. Guia de termos e expressões utilizados na Normalização. Rio de Janeiro: ABNT; SEBRAE, 2012. 62 p.

[2]. AMARAL, Celso G.F..CADEIA DE FRIO NA DISTRIBUIÇÃO FARMACÊUTICA. 2013. 80 p.. Dissertação de Mestrado - Universidade Fernando Pessoa, Portugal, 2013.

[3]. ASSOCIAÇÃO BRASILEIRA DE NORMAS TÉCNICAS. ABNT NBR ISSO 9000/2015: Sistemas de gestão da qualidade - Requisitos. Rio de Janeiro, 2015

[4]. BALLOU, R.H. Gerenciamento da cadeia de suprimentos/logística empresarial. 5a ed. Porto Alegre/SC: Bookman, 2006.

[5]. BAYER BRASIL- BAYER AG. Bayer no Brasil cresce 26\% em 2015 e mantém-se como o quarto maior mercado em faturamento do Grupo Bayer no mundo. Disponível em: $<$ https://www.bayer.com.br/midia/noticias/visualizanoticia. php?codNoticia=bayer-no-brasil-cresce-26em-2015-e-mantem-se-como-o-quarto-maiormercado-em-faturamento-do-grupo-bayer-nomundo>. Acesso em: 18 março 2018.

[6]. BERTAGLIA, Paulo Roberto. Logística e gerenciamento da cadeia de abastecimento. 2 . ed., rev. e atual. São Paulo: Saraiva, 2011. 546 p.

[7]. BNDES Setorial..Cadeia farmacêutica no Brasil: avaliaçãopreliminar e perspectivas. $N^{\circ} 18.3$ 22 p.. Rio de Janeiro, 2003.

[8]. BRASIL.RESOLUÇÃO DA DIRETORIA COLEGIADA - RDC No 157,DE 11 DE MAIO DE 2017. Diário Oficial, Brasília, DF, 15maio 2017. Nº 96, p. 40.

[9]. DYER, J..How Chrysler Created an American Keiretsu. Harvard Business Review, Boston. v.74, n.4, p.42-56, July-Aug.1996.

[10]. FEBRAFAR - FEDERAÇÃO BRASILEIRA DAS REDES ASSOCIATIVISTAS E INDEPENDENTES DE FARMÁCIAS. IMS: Mercado Farmacêutico Deve Atingir R\$ 87 Bilhões Em 2017. Disponivel em: <http://febrafar.com.br/imsmercado-farmaceutico-deve-atingir-r-87-bilhoesem-2017/>. Acesso em: 18 março 2018.

[11]. FEIGENBAUM, A.V. Controle da qualidade total. São Paulo: Makron Books, 1994.

[12]. G1 - CENTRAL GLOBO DE JORNALISMO. Farmacêuticas crescem há 10 farmacêutico de modo que o custo seja o menor possível com o melhor aproveitamento da ferramenta.

anos, superam dólar e querem 'mais PIB'. Disponível em: <http://g1.globo.com/sp/campinasregiao/noticia/2013/09/farmaceuticas-crescem-ha10-anos-superam-dolar-e-querem-mais-pib.html>. Acesso em: 29dez. 2017.

[13]. G1 - CENTRAL GLOBO DE JORNALISMO. PIB do Brasil terá $2^{\circ}$ pior desempenho do mundo em 2016. Disponível em: <http://g1.globo.com/economia/noticia/2016/02/pib -do-brasil-tera-2-pior-desempenho-do-mundo-em2016-aponta-fmi.html>. Acesso em: 5dez. 2017.

[14]. G1 - CENTRAL GLOBO DE JORNALISMO. Vendas da indústria farmacêutica crescem 13,1\% em 2016, diz Interfarma. Disponível em:

<https://g1.globo.com/economia/noticia/receitacom-vendas-de-remedios-cresce-131-em-2016diz-interfarma.ghtml>. Acesso em: 5dez. 2017.

[15]. GIL, A. C. Como Elaborar Projetos de Pesquisa. 4.ed. São Paulo: Atlas, 2012.

[16]. GIL, A.C. (2000) Métodos e técnicas de pesquisa social. São Paulo: Atlas (5ª . Ed.).

[17]. ICTQ - INSTITUTO DE CIÊNCIA, TECNOLOGIA E QUALIDADE. Perspectivas 2017: Quatro Boas Notícias Do Setor Farmacêutico. Disponível em: <http://www.ictq.com.br/industriafarmaceutica/614-perspectivas-2017-quatro-boasnoticias-do-setor-farmaceutico>. Acesso em: 26jan. 2018.

[18]. INTERFARMA - ASSOCIAÇÃO DA INDÚSTRIA FARMACÊUTICA DE PESQUISA. Dados de Mercado. Disponível em: <https://www.interfarma.org.br/guia/guia_2016/dad os_de_mercado>. Acesso em: 2fev. 2018.

[19]. INTERFARMA - Associação da Industria Farmacêutica de Pesquisa. Disponível em: $<$ https://www.interfarma.org.br/>. Acesso em: 5dez. 2017.

[20]. ITEC BRAZIL. A crise não chegou ao mercado farmacêutico. Disponível em: $<\mathrm{http}$ ://www.itecbrazil.com.br/crise-nao-chegou-aomercado-farmaceutico/>. Acesso em: 18 março 2018 .

[21]. ITEC BRAZIL. Crescimento do mercado farmacêutico. Disponivel em: $<$ http://www.itecbrazil.com.br/crescimentomercado-farmaceutico/>. Acessoem: 6 março 2018 .

[22]. JUNIOR, J.Y.S.; CORRÊA, H.L..CADEIA DE ABASTECIMENTO: GESTÃO DO ESTOQUE 
PELO DISTRIBUIDOR. 2008. 15 p.. Artigo Científico - RAE-eletrônica, Brasil, 2008.

[23]. JURAN, Joseph M.. Juran'sQualityHandbook. 5. ed., EUA: McGrawHill Book Company, 1998.

[24]. LANGSCHWAGER, Andrés S.M..A logística dos distribuidores farmacêuticos no Brasil: Um estudo de casos. 2002. 213 p.. Dissertação de Mestrado - Universidade do Rio de Janeiro, Rio de Janeiro, 2002

[25]. LEITE, C.C.L.; SOUZA, R.S.; SILVA, S.W.; PORTUAL, P.S.J.; OLIVEIRA, F.F..organização do abastecimento do hospital público a partir da cadeia produtiva: uma abordagem logística para a área de saúde. 2015. 12 p.. Artigo Científico Simpósio de excelência em gestão e tecnologia, Fiocruz, Minas Gerais, 2015

[26]. MACHADO, João G.C.F.; NANTES, José F.D..A rastreabilidade na cadeia da carne bovina. 2004. 11 p.. Artigo Científico - CONGRESSO LUSO-BRASILEIRO DE TECNOLOGIAS DE INFORMAÇÃO E COMUNICAÇÃO NA AGROPECUÁRIA, São Paulo, 2004.

[27]. MACHADO, Rosa T.M..RASTREABILIDADE, TECNOLOGIA DA INFORMAÇÃO E COORDENAÇÃO DE SISTEMAS AGROINDUSTRIAIS. 2000. 239 p.. Dissertação de Mestrado - Faculdade de Economia, Administração e Contabilidade da Universidade de São Paulo, São Paulo, 2000.

[28]. MAGALHÃES, L. C. G. et al. Diretrizes para uma Política Industrial de Medicamentos e Farmo-químicos. Ipea. Rio de Janeiro, 2003.

[29]. MAGALHÃES, L. C. G..Estratégias Empresariais de Crescimento na Indústria Farmacêutica Brasileira: Investimento, Fusões e Aquisições, 1988-2002. Ipea. Rio de Janeiro, 2003.

[30]. MAIO, Cláudia A.; SILVA, José L.G..Armazenagem e distribuição de medicamentos na cadeia fria. 2014. 19 p..ArtigoCientífico - LATIN AMERICAN JOURNAL OF BUSINESS MANAGEMENT, Brasil, 2014.

[31]. METZNER, Vivian C.V..PROPOSTA DE MODELO DE RASTREABILIDADE PARA O SETOR DE MEDICAMNETO NO BRASIL UTILIZANDO O CONCEITO DE INTERNET DAS COISAS. 2017. 73 p.. Dissertação de Mestrado - Escola Politécnica da Universidade de São Paulo, São Paulo, 2017.
[32]. NOVAES, Antônio Galvão. Logística e gerenciamento da cadeia de distribuição: estratégia, operação e avaliação. 3. ed., rev., atual. e ampl. Rio de Janeiro: Elsevier, 2007. xvi, 400 p.

[33]. SANTOS, Maria A.B.; INFANTE, Maria..Organização do abastecimento do hospital público a partir da cadeia produtiva: uma abordagem logística para a área de saúde. 2004. 10 p.. Artigo Científico - Escola Nacional de Saúde Pública, Fiocruz, Rio de Janeiro, 2007

[34]. SAYÃO, Miriam, LEITE, Júlio C.S.P..Rastreabilidade de Requisitos. 2005. 30 p.. Artigo Científico - Faculdade de Informática, PUCRS; DI/PUC-Rio, Rio Grande do Sul, 2005.

[35]. TONDOLO, Vilmar A.G.; Schneider, LuisC..VANTAGENS LOGÍSTICAS E CADEIA DE VALOR NA REDE DE EMPRESAS: O CASO DE UMA REDE GAÚCHA DE PEQUENAS FARMÁCIAS. 2005. 18 p.. Artigo Científico - Revista Alcance, Rio Grande do Sul, 2005.

[36]. TRIVIÑOS, A.N.S. (1990) Introdução à Pesquisa em Ciências Sociais: a pesquisa qualitativa em educação. São Paulo: ATLAS.

[37]. VERBEKE, W. \& VIAENE, J. Demandoriented meat chain management: the emerging role of traceability and information flows. In: INTERNATIONAL CONFERENCE ON CHAIN MANAGEMENT IN AGRIBUSINESS AND THE FOOD INDUSTRY, 2000, Wageningen. Proceedings of the Fourth International Conference on Chain Management in Agribusiness and the Food Industry. Wageningen: Wageningen University Publisher, 2000.

[38]. Viana, J.G.A.; Cartes, G.S.; Fornazier, A.; Spohr, G.; Silva, T.N..PERCEPÇÃO DOS PRODUTORES FRENTE À RASTREABILIDADE BOVINA: ESTUDO COMPARATIVO ENTRE BRASIL E CHILE. 2010. 4 p.. Artigo Científico Universidade Federal do Rio Grande do Sul, Rio Grande do Sul, 2010

[39]. VINHOLIS, Marcela M.B.; AZEVEDO, Paulo F..SEGURANÇA DO ALIMENTO E RASTREABILIDADE: O CASO BSE. 2002. 19 p.. ArtigoCientífico - RAE-eletrônica, São Paulo, 2002.

[40]. YIN, R. K. (1994) Case study research: design and methods. London: SAGE (2a ed.). 


\section{Bapítulo 6}

\section{FORMACÃO DE ENGENHEIROS EM CURSOS DE GRADUAÇÃO E PÓS-GRADUAČ̃̃O NO ENSINO A DISTANCIA - FUNDAMENTAÇÃO DO PROCESSO DE "OUVIR" DO DESIGN THINKING PARA A TUTORIA PEDAGÓGICA EM DISCIPLINAS DE PROJETOS}

\section{Ricardo Venturineli}

Júlio Cesar Ferreira dos Passos

Maria Juliana Góes Coelho da Cruz

Simone Seixas Picarelli

Resumo: O presente artigo dedica-se ao aprimoramento de modelos pedagógicos para o Ensino a Distância de cursos de graduação e pós-graduação nas diversas áreas da Engenharia. Para esse propósito, elabora-se nesta pesquisa o embasamento científico, o detalhamento dos meios tecnológicos de suporte à disciplina e o percurso metodológico para a realização prática do processo de "Ouvir" do Design Thinking. O desenvolvimento deste trabalho resulta na produção de elementos pedagógicos fundamentais para o estado da arte nas práticas de tutoria e para o ensino e a aprendizagem em disciplinas de projetos. A formação científica de Engenheiros na atualidade é tributária de modelos pedagógicos constituídos de características especificas para o Ensino a Distância e a produção deste artigo cumpre um relevante papel na contemporaneidade, no que tange o processo de "Ouvir" do Design Thinking.

Palavras-chave: Educação a Distância. Human Centered Design. Processo de "Ouvir. Design Thinking 


\section{INTRODUÇÃO}

O presente artigo possui sua gênese na necessidade do aprimoramento das práticas de tutoria em disciplinas de projeto de cursos de graduação e pós-graduação - das diversas áreas da Engenharia - realizados na modalidade de Ensino a Distância (EAD) cujo modelo pedagógico determina $\mathrm{O}$ desenvolvimento de um projeto de solução de problemas com a utilização da técnica do Design Thinking (DT) por grupos de estudantes.

A pertinência desta pesquisa se funda na necessidade de se aprimorar os processos pedagógicos para os cursos de graduação e pós-graduação no EAD, modalidade de ensino em franca expansão.

\section{Explica-se esta expansão pela}

[...] priorização de políticas que ampliem o acesso ao ensino superior,. que almejem a qualidade e a equidade na educação. Para atingir esses objetivos ... é necessário adotar novas perspectivas, . sistemas educativos baseados em "open and distance learning" e utilização de Tecnologias de Comunicação e Informação (TICs). Tais perspectivas permitiriam ampliar o acesso à educação de qualidade, e as TICs empregadas no ensino e na aprendizagem poderiam propiciar condições de ampliação ao acesso, à qualidade e promover o êxito na educação. (UNESCO, 2009).

É capital, portanto, a proposição e aprimoramento de novas abordagens educacionais que sejam adequadas para a construção de um modelo pedagógico dedicado a formação em Engenharia no EAD.

Nestes termos, o presente projeto de pesquisa consiste na produção de material pedagógico visando fornecer as bases científicas para o estado da arte nas práticas de tutoria, através do estabelecimento da fundamentação teórica, dos meios tecnológicos de apoio e do percurso metodológico que envolvem estas atividades visando o desenvolvimento de conhecimentos específicos para a formação em engenharia no EAD.

Para interesse deste artigo, o cerne da pesquisa é especificamente o processo do "Ouvir" do DT e, neste diapasão, cumpre estabelecer as fases de desenvolvimento do projeto no modelo pedagógico em questão. Realiza-se a proposição de um tema atinente ao curso de graduação em Engenharia, o detalhamento dos conteúdos disciplinares que envolvem o tema proposto, os objetivos de aprendizagem e o foco metodológico, considerando-se a utilização de dois ou mais elementos tecnológicos de apoio para a apropriação dos conteúdos disciplinares e os referenciais teóricos que fundamentam a proposta.

A hipótese exposta aqui é de que o estado da arte nas práticas que envolvem a tutoria de disciplinas de projetos possui importância fulcral para a formação científica nas diversas áreas da Engenharia no EAD, modalidade fundamental na contemporaneidade. Isso se deve ao fato de que o referencial teórico oferece substância norteadora para as práticas de tutoria nas disciplinas de projetos desenvolvidas com o DT, técnica de resolução de problemas com propostas inovadoras.

O resultado esperado deste artigo é que haja a produção das bases para a realização das melhores práticas de tutoria propiciando, por sua vez, o desenvolvimento de competências e habilidades de pesquisa que permitam e inspirem aos integrantes dos grupos de $\mathrm{Pl}$ a proposição de soluções inovadoras para problemas, condizentes com o dinamismo do cenário do mercado contemporâneo.

\section{MATERIAIS}

Da perspectiva teórica, um elemento imprescindível para a aprendizagem através do EAD é a utilização de disciplina de projetos. O modelo pedagógico da disciplina compreende a composição de grupos colaborativos de três a sete estudantes formados aleatoriamente, objetivando a resolução de problemas por projetos com a utilização de ferramenta DT, que conforme Vianna et al (2012) "é uma abordagem focada no ser humano que vê na multidisciplinaridade, colaboração e tangibilização de pensamentos e processos, caminhos que levam a soluções inovadoras para negócios".

\section{Processo de Ouvir do Design Thinking}

Com relação à conteúdo, Behar, (2009) advoga que entende-se que este se caracteriza por ser qualquer tipo de material e/ou elemento(s) utilizado(s) com a finalidade de apropriação do conhecimento (BEHAR, 2009).

Este mesmo autor explica que as 
[...] competências são formadas por conhecimentos, habilidades e atitudes (CHA) mobilizados em uma situação para resolver um problema, lidar com uma novidade ou imprevisto, o que exige reflexão e avaliação, além de relacionar-se a um contexto (BEHAR, 2016, p. 6).

Os conteúdos cujas fundamentação teórica, meios tecnológicos de apoio e o percurso metodológico estabelecem-se neste artigo são ao mesmo tempo, processos de ensino e de aprendizagem do processo de "ouvir" do DT.

Segundo o material Human Centered Design (HCD) produzido pela empresa de consultoria em inovação IDEO, "O ato de projetar soluções inovadoras e relevantes, que atendam às necessidades das pessoas, começa com o entendimento de suas necessidades, expectativas e aspirações para o futuro" (Human Centered Design, 2009).

O processo de "Ouvir" do DT oferece as metodologias para a abordagem das pessoas - público-alvo - em seus próprios contextos para que haja uma profunda compreensão de seus problemas e possui como objetivo dar as bases para a determinação de quem deve ser abordado, dicas para estabelecer empatia e, por fim, realizar a coleta de histórias.

Como resultados, deve-se obter as histórias das pessoas, observando-se a realidade do público alvo envolvido com o problema para o qual pretende-se propor soluções inovadoras e o entendimento profundo de suas necessidades, barreiras e restrições.

Segundo consta no material do HCD (2009):

Métodos qualitativos de pesquisa permitem à equipe de projeto desenvolver empatia pelas pessoas para as quais o projeto está sendo desenvolvido, além de permitir que a equipe questione suposições e inspirar novas soluções. No início do processo, a pesquisa é generativa - usada para estimular a imaginação e informar a intuição sobre novas oportunidades e idéias. Nas fases finais, os métodos são avaliatórios - usados para determinar rapidamente a maneira como as pessoas reagem às idéias e soluções propostas. (Human Centered Design, 2009)

O processo de "Ouvir" do DT é composto pelas seguintes fases:

- Identificação de um desafio
estratégico;

- Avaliação dos conhecimentos preexistentes;

- Identificação de pessoas com quem conversar;

- Escolha dos métodos de pesquisa e
- Desenvolvimento da abordagem de entrevista.

A seguir, detalha-se os conteúdos de cada uma das etapas do processo de "Ouvir".

\section{a) Identificação de um desafio estratégico}

O estabelecimento de um desafio estratégico acurado é um fator crucial para a elaboração de propostas inovadoras em um projeto centrado no ser humano e é o material que serve de base para a elaboração das perguntas que serão utilizadas para as pesquisas de campo e, posteriormente, para a proposição de soluções. A estratégia adequada para a realização da entrevista pauta-se na estratégia de equilibrar a necessidade da coleta das informações relevantes do entrevistado e a de se estabelecer um contato mais próximo, com empatia.

\section{b) Avaliação dos conhecimentos preexistentes}

Esta etapa visa estimular a ideação da solução inovadora utilizando-se de conhecimentos pré-existentes através da discussão com o grupo de projeto. Cada integrante do projeto escreve seus conhecimentos prévios em bilhetes que serão discutidos com todo o grupo. Inclui também nesta etapa escrever em bilhetes o que não se conhece sobre o problema, para que haja a discussão e sistematização dos procedimentos para a aquisição destes conhecimentos.

\section{c) Identificação de pessoas com quem conversar}

A escolha dos participantes adequados é crucial para o processo de "Ouvir" do DT. Deve-se procurar obter um balanço entre sexos, etnias, e classes sociais para obtenção de bons resultados de pesquisa.

Uma estratégia adicional de pesquisa para a proposição de soluções inovadoras é incluir pessoas que representem os "extremos". Isso se deve ao fato de que estes perfis de participantes ajudam a revelar os comportamentos, desejos e necessidades do restante da população que envolve o públicoalvo: extremos são mais fáceis de observar e 
identificar. Mas é importante incluir ambos os extremos e as pessoas médias entre os extremos.

Destarte, toda a escala de comportamentos, crenças e perspectivas serão ouvidas.

\section{d) Escolha dos métodos de pesquisa}

Os métodos de pesquisa para coleta de dados indicados no material do HCD (2009) são os que seguem:

$\begin{array}{ll}\text { - } & \text { Entrevistas individuais; } \\ \text { - } \quad \text { Imersão em contexto; } \\ \text { - } \quad \text { Auto-documentação; } \\ \text { - } \quad \text { Descoberta guiada pela comunidade; } \\ \text { - } \quad \text { Entrevistas com experts e } \\ \text { Buscar inspiração em novos locais. }\end{array}$

e) Desenvolvimento da abordagem de entrevista

As estratégias de entrevista indicadas pelo HCD para o desenvolvimento de uma abordagem adequadas são:

- Guia de Entrevista;

- Conceitos Sacrificiais e

- Técnicas de Entrevista.

\section{Elementos Tecnológicos de Apoio}

Kenski (2013) advoga que

As alterações sociais decorrentes da banalização do uso das tecnologias eletrônicas de informação e comunicação e do acesso a elas atingem todas as instituições e espaços sociais. Na era da informação, comportamentos, práticas, informações e saberes se alteram com extrema velocidade. Um saber ampliado e mutante caracteriza o estágio do conhecimento na atualidade. (KENSKI, 2013, p. 41)

Este fato e a busca pelo estado da arte na formação educativa implicam em uma constante revisão dos elementos pedagógicos de apoio ao ensino.

Utiliza-se os seguintes elementos tecnológicos de apoio para a aprendizagem:

- Computador com microfone, acesso a internet e webcam;

- Serviço de correio eletrônico Google Gmail;
- Serviço de agenda e calendário Google Calendar,

- Plataforma de mensagens instantâneas e chat de vídeos Google Hangouts;

- Serviço de armazenamento e sincronização de arquivos Google Drive;

- Serviço de criação e edição de documentos Google Docs e

- Site de compartilhamento de vídeos Youtube.

\section{PERCURSO METODOLÓGICO}

A aprendizagem do processo de "Ouvir" do DT realiza-se através de um percurso metodológico, explicado em detalhes a seguir.

Um tutor virtual faz a apresentação dos conteúdos, além realizar a orientação e avaliação da apropriação dos conhecimentos.

Chaquime e Mill (2015) afirmam que

[...] o tutor virtual é figura central. Isso porque, ao atuar bem próximo ao aluno, interagindo diretamente no AVA como motivador do processo de ensinoaprendizagem, o tutor virtual representa a instituição, além de ser identificado, pelos alunos, como seu "professor" efetivamente. (CHAQUIME E MILL, 2015, p. 3)

Utiliza-se o Google Drive para armazenar e compartilhar os materiais de apoio para a apresentação dos os conteúdos disciplinares. Cria-se também um documento no Google Docs com o link dos vídeos disponibilizados no Youtube como forma de facilitar o acesso aos integrantes dos grupos.

Para a aprendizagem do processo de ouvir, utiliza-se seguintes recursos educacionais:

- Arquivo no formato pdf do Human Centered Design com o Kit de ferramentas DT, disponibilizado também no sítio <http://brazil.enactusglobal.org/wpcontent/uploads/sites/2/2017/01/FieldGuide-to-Human-CenteredDesign_IDEOorg_Portuguese73079ef0d58c8ba42995722f1463bf4b .pdf>.

- Vídeo simplificado sobre os processos do DT disponibilizado no sítio 
$<$ https://www.youtube.com/watch?v=B wjwb5alcZ8>.

- Vídeo sobre o IDEO e a utilização do DT disponibilizado no sítio $<$ https://www.youtube.com/watch?v=i 4PGOc0-vOU>.

Os grupos devem criar um documento no Google Docs com a finalidade de descrever a realização da prática do processo de "Ouvir". Desta forma, a tutoria pode realizar a orientação e a avaliação sobre a efetividade da compreensão dos conceitos pelos integrantes dos grupos de projeto.

Destinam-se três encontros virtuais síncronos com duração de duas horas cada entre a tutoria e os grupos de projeto com a finalidade da apresentação dos materiais sobre o assunto e orientação pedagógica. Para isso, cria-se um evento através do Google Calendar e envia-se o convite a todos os interessados. Este serviço de agenda envia automaticamente o aviso do evento através do correio eletrônico Gmail e os encontros são consubstanciados por intermédio do Google Hangouts. Na data do e horário do evento, utiliza-se um computador com microfone, acesso à internet e webcam para que seja estabelecida uma comunicação com qualidade suficiente para interação entre tutor e os integrantes dos grupos de projeto.

O primeiro encontro possui o intuito de apresentar os conteúdos para o aprendizado a todos os estudantes, de forma conjunta. Neste encontro são apresentados os materiais do HCD, vídeos do Youtube e orientações com o conhecimento pré-existente do tutor. Solicita-se, ainda, que os grupos criem os documentos no Google Docs descrevendo os detalhes específicos do projeto de cada grupo e a preparação para a prática do processo de "Ouvir".

O segundo encontro tem o seu tempo de duração dividido entre os diversos grupos de projeto e possui o objetivo da verificação da compreensão sobre os conteúdos apresentados no primeiro encontro. Isso se dá pela observação das escolhas de metodologia pelo grupo de projeto e a relação com o problema específico estudado. Realiza-se orientações para obtenção do alinhamento metodológico dos conteúdos disciplinares apresentados sobre o processo de "Ouvir com relação ao tema de projeto da disciplina do Projeto Integrador e a escolha de estratégias pelos grupos de projeto e, quando necessário, solicita-se a realização de ajustes. Este momento oferece a oportunidade de sugerir novas orientações que visam efetivar a compreensão correta dos conhecimentos pelos integrantes dos grupos de projeto. Solicita-se, então, que os grupos realizem na prática, o processo de "Ouvir" do DT seguindo as teorias apresentadas e as estratégias traçadas nos dois primeiros encontros, devendo-se realizar a documentação de todo o processo com imagens, fotografias e descrição escrita no documento compartilhado no Google Docs.

No terceiro encontro realiza-se a avaliação e orientação posterior à realização da prática do processo de "Ouvir". Devido as novas orientações ocorrerem após a apresentação da teoria adequada e da escolha dos métodos e estratégias - realizados no primeiro encontro - e, após as orientações e possíveis ajustes - realizados no segundo encontro - o terceiro encontro serve para que, de uma lado, o tutor realize a avaliação da descrição da prática do processo de "Ouvir" feita no do documento compartilhado no Google Docs pelos integrantes dos grupos de projeto, além das últimas orientações. De outro lado, os integrantes dos grupos realizam a abstração da realidade de forma ainda mais refinada, outorgando mais qualidade ao conhecimento adquirido.

\section{CONSIDERAÇÕES FINAIS}

Este artigo apresentou a fundamentação teórica, os meios tecnológicos de apoio e o percurso metodológico para a composição de um modelos pedagógico para aplicação da disciplina de projetos em cursos de graduação e pós-graduação das diversas áreas da engenharia.

Estes elementos são os parâmetros científicos basilares para as práticas de tutoria especializada, no que tange a orientação sobre o processo de "Ouvir" do DT à integrantes de grupos de projeto que, por sua vez, promovem aos estudantes de engenharia o desenvolvimento de competências e habilidades de pesquisa para a proposição de soluções inovadoras de problemas e com foco no ser humano.

Destarte, estabeleceu-se as bases para o aprimoramento dos processos pedagógicos de modelos voltados à graduação e pósgraduação nas diversas áreas da engenharia em EAD através da realização de projetos. 


\section{REFERENCIAS}

[1]. BEHAR, P. A. Modelos Pedagógicos para a Educação a Distância. Porto Alegre: Artmed, 2009. Acessado em 17 de jan. 2018. Disponível em:

$<$ http://www.nuted.ufrgs.br/oa/arqueads/apoio/mod elospedagogicos.pdf >

[2]. BEHAR, P. A., SCHNEIDER, D. Modelos Pedagógicos e Competências em Educação a Distância: a construção do MP-CompEAD. R. Educ. Públ. Cuiaba, v. 25, n. 59/2, p. 504-524, maio/ago. 2016. Acessado em 17 de jan. 2018. Disponível em:

$<$ http://periodicoscientificos.ufmt.br/ojs/index.php/e ducacaopublica/article/view/3832/2613>

[3]. CHAQUIME, L. P., MILL, D. A. Docência virtual e saberes docentes: um estudo da tutoria na rede E-tec Brasil. Revista da FAEEBA - Educação e Contemporaneidade, Salvador, v. 24, n. 44, p. 97-107, jul./dez. 2015

[4]. IDEO. Human Centered Design. 2009 Acessado em 17 de jan. 2018. Disponível em: $<$ http://brazil.enactusglobal.org/wp-
content/uploads/sites/2/2017/01/Field-Guide-toHuman-Centered-Design_IDEOorg_Portuguese3079ef0d58c8ba42995722f1463bf4b.pdf>

[5]. KENSKI, V. M. Tecnologias e ensino presencial e a distância. Campinas, SP: Papirus, 2003.

[6]. ORGANIZAÇÃO EDUCACIONAL CIENTÍFICA E CULTURAL DAS NAÇÕES UNIDAS UNESCO. Final Communique: World Conference on Higher Education: the new dynamics of higher education and research for societal change and development. Paris: UNESCO, 2009.

[7]. VIANNA, M. J., VIANNA, S. Y. Design Thinking: inovação em negócios. Maurício Vianna... [et al.].

[8]. Janeiro :MJV Press, 2012. 162p. : il. ; $24 \mathrm{~cm}$. 


\section{Capítulo 7}

\section{INOVACÃO E EMPREENDEDORISMO: APRENDENDO E CONSTRUINDO GESTÃO ESTRATÉGICA- ORGANIZACIONAL EM UMA MICROEMPRESA}

\section{Isis Emanuelle Correia da Silva}

\section{Juliane dos Santos da Silva}

Natan Gabriel de Paula Santos

Viviane Freire dos Santos

\section{Pietra Monteiro de Oliveira Silva}

Resumo: Empreender significa ter a ideia de negócio ou projeto e saber como transformá-los em sucesso e, posteriormente revertê-los em ganhos financeiros. Entretanto, para isso o futuro empreendedor deve estar atento às práticas e teorias administrativas e todo o sistema que envolve esses conhecimentos, suas frequentes inovações e necessidades de clientes que se modificam a cada dia. Este artigo objetiva mapear teorias administrativas, assim como, o seu desmembramento para o empreendedorismo e, analisar em campo essas teorias e práticas quando aplicadas por um microempreendedor em uma empresa de pequeno porte. O método escolhido para a constituição do conteúdo do trabalho foi baseado em pesquisa exploratória bibliográfica apoiada por pesquisa de campo cujas teorias administrativas e técnicas de gestão puderam ser comparadas aos exemplos reais, valorizando o exposto em sala de aula. Dessa forma, foi melhor entendido com esse trabalho as funções de um gestor e a maneira que ele empreende.

Palavras-chave: empreendedorismo, estratégia, gestão. 


\section{INTRODUÇÃO}

O Brasil ainda se encontra em tempos de crise financeira que sujeita famílias brasileiras a terem seu poder de compra e possibilidade de ganhos diminuídos. Frente a isso, o comércio se torna um importante aliado para que essas famílias se distanciem dos impactos dessa crise, pois, através de pequenos negócios ou prestação de serviços pode acontecer o acúmulo de capital ou recuperação de renda causando enriquecimento dos vários agentes envolvidos nesta ação humana.

Preocupados em empreender com inovação e, simultaneamente, construir uma gestão estratégica e organizacional em uma microempresa, um mercado familiar, uma família comercializa alimentos e produtos para uso doméstico de natureza diversa na cidade Guaratinguetá, atendendo a microrregião do bairro Pedregulho. Os proprietários são responsáveis pelo gerenciamento diverso (estoque, distribuição de funções e pagamento de funcionários), o ambiente é dividido por setores, na entrada está o caixa, em seguida, entrando no prédio, existem gôndolas para alimentos e geladeiras para bebidas e nos fundos do edifício ficam açougue e padaria. Também nos fundos encontra-se um pequeno estoque.

Cada funcionário é destinado à uma destas seções. Assim, se formaram grupos de trabalho que tem por objetivo solucionar os problemas decorrentes das vendas, como a falta de produtos nas gôndolas e geladeiras, o suprimento de carne no açougue e a produção de pães e corte dos frios. Por fim, no caixa ocorrem as transações financeiras entre o dono e o cliente que realiza as compras.

Dessa forma, a importância desse trabalho está em elucidar as formas administrativas utilizadas por um microempresário em seu estabelecimento com o intuito de avaliar como o mais importante operador financial estrutura os seus negócios. A problemática deste artigo se resume na possibilidade de aplicar os conceitos e exemplos administrativos adquiridos em uma aula de administração geral e, em um ambiente real, comprovar essas teorias e práticas, considerando a hipótese de conseguir com esta pesquisa, agregar mais conhecimento sobre a temática, incrementar as aulas antes apenas teóricas e motivar os futuros tecnólogos em sua profissão.
Como Objetivo Geral, este trabalho propõe levantar as teorias administrativas aplicadas por microempreendedores, além de, delimitar a pesquisa em uma empresa de pequeno porte. Já os objetivos específicos foram identificar as abordagens administrativas através de um questionário respondido pelo proprietário e colaboradores; desenvolver as competências necessárias para pesquisa de campo; categorizar as perguntas do questionário segundo o contexto administrativo em que ela foi elaborada; analisar como ambiente de trabalho é estruturado; estudar administração exercida diariamente e identificar quais teorias funcionam e se adequam melhor longe do campo ideal.

Esperou-se com os resultados obtidos com a bibliografia e as conclusões das visitas (ou pesquisa de campo) que mais conhecimento fosse agregado ao conteúdo exposto em sala da aula, o que realmente aconteceu, ou seja, aprendeu-se em experiencia prática como se constrói a gestão estratégica-organizacional. Fica então, o sentimento de que mais pesquisas práticas sejam feitas por todo o curso.

\section{EMBASAMENTO TEÓRICO - REVISÃO DA LITERATURA}

Desde que o homem abandonou o sedentarismo e estabeleceu morada fixa foi preciso que ele aprendesse a racionar sobre a escassez de recursos, além de gerenciar pessoas, animais e o próprio tempo. Conforme ele aperfeiçoava técnicas de plantio, caça, pesca e escambo, tradições milenares foram transmitidas através das gerações por uso e costumes e, que hoje podem ser entendidas como ações de administração.

A seguir, nesta revisão, são apresentadas algumas das principais abordagens e/ou teorias administrativas desenvolvidas nos dois últimos séculos. Esta revisão também contempla base conceitual sobre pequenas e médias empresas, como também, base para inovação e empreendedorismo, de forma que no foco da pesquisa, as microempresas, tais práticas sejam caracterizadas.

\subsection{TEORIAS ADMINISTRATIVAS}

Desenvolvida pelo engenheiro Frederick Taylor, a Administração Científica tem ênfase 
nas tarefas, é baseada nos princípios de divisão do trabalho, estudos e padronização dos tempos e movimentos de execução de uma tarefa, maior remuneração para aquele que produz mais e supervisão dos funcionários na realização de suas funções. Taylor entendia que a eficiência da empresa dependia da soma de todas as tarefas nucleares realizadas de maneira eficiente (CHIAVENATO, 2014; DAFT, 2017).

Henri Fayol multiplicou a Teoria Clássica da Administração. Fayol postulou que em qualquer livre associação entre seres humanos haveria a necessidade de planejamento, organização, comando, coordenação e controle, em algum nível. Em sua teoria geral, Fayol explicou os papeis de um dirigente, que em sua visão se distinguem dos outros papéis da empresa. Para ele, a função era a mais importante, pois caberia ao administrador orquestrar todos os funcionários, estando um nível acima na hierarquia do trabalho. Além disso, caberia ao dirigente cuidar da documentação e processos burocráticos para que não se tornassem demasiados (CHIAVENATO, 2014; MAXIMIANO, 2015).

Cooperando com o classicismo, Henry Ford ganhou notoriedade pelo desenvolvimento da linha de montagem, que visava a produção em massa a partir dos princípios da uniformidade de peças e especialização do trabalhador. Assim, o expoente fragmentou a produção em partes e o processo produtivo em etapas. Devido à sua objetividade, a linha de montagem foi adotada em todo o mundo o que estimulou as fábricas e gerou empregos e prosperidade aos que adotaram suas práticas de gestão (MAXIMIANO, 2015, DAFT, 2017).

Em paralelo à formação do capitalismo, o sociólogo alemão Max Weber desenvolveu pesquisas sobre as organizações formais de sua época. Ele concluiu que havia um tipo "ideal de Burocracia", uma generalização de características que notou presentes nas empresas de seu tempo. Weber entendia que todas as organizações poderiam seguir um sistema de leis racionais, assim, para essas empresas funcionariam como sistemas de normas racionais que determinavam 0 comportamento das pessoas, adequados a estrutura burocrática (BATEMAN; SNELL, 1998; CHIAVENATO, 2014).

Segundo Chiavenato (2014) e Maximiano (2015), a visão do ser humano como uma peça dentro do sistema produtivo começou a ser questionada quando Elton Mayo, conduziu entrevistas com os trabalhadores envolvidos em Hawthorne, e delas concluiu que pode-se atribuir o aumento de eficiência a um melhoramento do moral. Portanto, quão melhor fosse o gerente e a forma que ele tratava seus empregados, melhor seria o desempenho dos mesmos. Ele também concluiu que havia relações informais entre os operários e que esses vínculos eram mais fortes que os da gerência e seus colaborados, assim, para que houvesse cooperação os grupos informais precisavam estar em sintonia com os interesses da empresa.

Colaborando também com o desenvolvimento administrativo, o psicólogo alemão-americano Kurt Lewin desenvolveu uma nova perspectiva para esta ciência também tendo como base o comportamento humano. Em sua teoria, declara o ser humano como a parte fundamental das empresas e, se divide em duas grandes áreas: o estudo das pessoas como indivíduos e o estudo das pessoas como membros de grupos (CHIAVENATO, 2014; MAXIMIANO, 2015).

Por Amitai Atizioni, surgiu o Estruturalismo, teoria que explora e conecta conceitos Classicistas e Humanistas que considerava os resultados do "todo" ou toda parte de uma organização muito maior que os resultados de suas partes individualizadas, teoria esta que também analisou com ênfase questões relacionadas à estratégia, objetivos, sociedade, ambiente e conflitos (CHIAVENATO, 2014; MAXIMIANO, 2015; DAFT, 2017).

Proposta por Ludwig von Bertalanffy, a Teoria Geral dos Sistemas apresenta duas diretrizes, a primeira é a afirmação de que a realidade do sucesso corporativo se dá diante da composição de sistemas integrados e, que neles não existem elementos sem relação entre si, já a segunda é uma implicação da primeira, que diz que para se entender o "todo organizacional" é preciso analisar os elementos que o compõe, bem como suas inter-relações. Para o autor, o enfoque sistêmico se define pela visão da unidade (CHIAVENATO, 2014; MAXIMIANO, 2015; DAFT, 2017).

Peter Drucker foi um dos expoentes pioneiros a teorizar, praticar e publicar vários trabalhos sobre a abordagem que mais tarde seria nomeada Neoclássica. A ideia foi integrar 
tudo o que funcionara no passado e reorganizar as empresas com foco nas atividades administrativas, ênfase em resultados e objetivos e busca conjunta de eficiência e eficácia. Acolhendo qualquer nova abordagem que corroborasse bons resultados, buscando o melhor aproveitamento da essência de todas as abordagens (CHIAVENATO, 2014). A Administração por Objetivos ou APO, é oriunda da Teoria Neoclássica e, segundo o Prof. Peter Druker (BATEMAN; SNELL, 1998; CHIAVENATO, 2014), tem como base um processo todos partilham o processo de tomada de decisão, chefias e colaboradores, todos pleiteando um mesmo objetivo. Esse processo substitui o processo hierárquico tradicional (clássico), onde o chefe define os objetivos e os transmite, para depois avaliar o desempenho da equipe. Tem ênfase no planejamento e no controle, onde o ponto de partida é a fixação dos objetivos da organização e, nas declarações escritas do que se pretende alcançar em conjunto. Também se caracteriza pela reciclagem dos funcionários, o que os torna cada vez mais qualificados, assim como, na reciclagem dos projetos. Estes quando atingidos, tem suas porcentagens gradativamente aumentadas, de modo que os funcionários, motivados, sempre superem suas metas e expectativas.

Considerada uma das mais recentes, a Teoria Contingencial que dentre vários colaboradores se destacam Lawrence e Lorsch, se fundamenta no princípio de que não existe uma única forma de organização já que todas as organizações estão sujeitas às mudanças externas e, é necessário que as empresas consigam se adaptar a qualquer cenário (BATEMAN; SNELL, 1998; CHIAVENATO, 2014). Assim, da soma de todas abordagens, do conhecimento, virtudes e (inclusive) falhas que se resume a Teoria Contingencial, cujo o maior objetivo é o uso da estratégia para resolução de problemas, aplicando no processo as bases que estruturaram cada teoria ou abordagem, portanto, quando o ambiente externo muda, a administração e estrutura corporativa também o fazem (CHIAVENATO, 2014; MAXIMIANO, 2015).

\subsection{DAS PEQUENAS E MÉDIAS EMPRESAS PARA A MICROEMPRESA}

O futuro das pequenas empresas consiste em integrar recursos tecnológicos (e de inovação) como fatores de diferenciação, o que contribui na manutenção de padrões de competitividade análogos com grandes organizações e constitui a diferença entre desaparecer e sobreviver, já que no Brasil, a competitividade dessas organizações é essencial ao desenvolvimento do país (MENDES; ESCRIVÃO FILHO, 2007; RIBEIRO; MILANI, 2009). Com o sucesso de algumas delas tornou-se necessário mapeá-las, classificá-las e investigar como estão inovando. Staley (1958) e Schumacher (1977), propuseram como características essenciais das pequenas empresas: a direção relativamente pouco especializada, relações pessoais estreitas entre os dirigentes, encarregados, clientes e fornecedores, falta de acesso ao capital através de um mercado de capital organizado e falta de força particular em negociações de compras e vendas e forte integração à comunidade pertencente. Com isso o interesse por unidades empresariais de porte reduzido despontou (LARA, 1993) assim como governos começaram a se interessar pela proteção e o desenvolvimento desses negócios.

Filion (1990), ainda explica que a maioria das tentativas de definição para uma tipologia de pequenas empresas nos mais variados países foram realizadas, não apenas por razões fiscais, mas sim, porque existia a necessidade de estabelecer parâmetros de identificação de empresas elegíveis para receber diferentes tipos de benefício oferecidos pelos governos, por exemplo, adotando esses parâmetros estabelecidos, pode-se selecionar empresas potenciais para programas de terceirização ou de fornecimento de produtos e serviços para o próprio governo. Já Leone (1991) enfatiza alguns critérios utilizados para caracterizar ou classificar as pequenas empresas:

- número de empregados: critério quantitativo, fácil de manipular e coletar, é critério tanto econômico como social pois na definição do tamanho da empresa, está implícita a premissa de que esse critério determina também a produtividade ou o valor da transformação industrial;

- faturamento ou vendas: critério quantitativo que indica o movimento operacional financeiro da empresa e, com a Receita Federal Brasileira como parceira, combinado ao capital social objetiva a execução da política fiscal que resulta em grande apoio para o segmento. 
De acordo com o SEBRAE (2014), a classificação ou porte entre as empresas se dá pelo seguinte critério apresentado na Tabela 1:

Tabela 1: Critério de Classificação do Porte de Empresas - № de Colaboradores

\begin{tabular}{|c|c|c|}
\hline Classificação & Indústria & Comércio e Serviços \\
\hline Micro & Até 19 & Até 09 \\
\hline Pequenas & $20-99$ & $10-49$ \\
\hline Médias & $100-499$ & $50-99$ \\
\hline Grandes & Acima de 500 & Acima de 100 \\
\hline
\end{tabular}

Fonte: Adaptado de SEBRAE (2014)

\subsection{INOVAÇÃO E EMPREENDEDORISMO}

A palavra inovação é um vocábulo latino proveniente de innovare que significa fazer algo novo, tornar possibilidades em novas ideias reais, colocando estas em prática (FREEMAN; SOETE, 1997; PLONSKI, 2005; ZANELLA, et al. 2012). Dessa forma, a inovação é um processo de transformação ou evolução de ideias dentro da organização, por meio de uma sequência temporal de atividades até sua oferta ao mercado (VAN de VEM; ANGLE; POOLE, 2000; SILVA; BAGNOB; SALERNOC, 2014). Embora a definição de inovação esteja presente na cultura organizacional, ela sempre se renova, entretanto, interpretá-la e condicionar empresas para um ambiente favorável à inovação é uma dificuldade a ser enfrentada no país, quando este pretenda se inserir de forma competitiva, nacional ou globalmente (MACHADO; DE CARVALHO; HEINZMANN, 2012; BRUNO-FARIA, M. F.; FONSECA, 2014; DE PAULA, 2014). A inovação, consiste então, na recriação sob uma visão peculiar ou ideal e, a técnica ao fazê-lo é o que fomenta a inovação, pois envolve tanto as ideologias quanto o entendimento delas (DÁVILA; LEOCÁDIO; VARVAKIS, 2008; TAKEUCHI, NONAKA, 2008; LEHNER; HALLIDAY, 2014). A inovação acontece, então, pela inserção de um novo bem desconhecido, uma qualidade nova deste, ou um novo método de produção ainda não testado, que tenha sido baseado em uma nova manifestação científica criativa que resulte um novo modo de exploração comercial de um bem (ALMEIDA, 1981; DOSI, 2006; FUZETTI, 2011).

Já o empreendedorismo é definido por Dornelas (2004) como uma prática muito abrangente na gestão e pode ser aplicado a diversos tipos de organização, incluindo empresas consolidadas ou por aquelas que ainda buscam por seus melhores caminhos. Ainda Segundo o autor (DORNELAS, 2004), os vários aspectos que envolvem o processo empreendedor como a análise de oportunidade, a equipe empreendedora e os recursos para o desenvolvimento do negócio, são analisados à luz do empreendedorismo corporativo. Dornelas (2003), complementa, explicado que empreender significa fazer algo novo, buscar novas oportunidades de negócio, tendo como foco a inovação e a criação de valor e que a essência do empreendedorismo se resume em fazer diferente, empregar os recursos disponíveis de forma criativa, assumir riscos calculados, buscar oportunidades e inovar.

Morris e Kuratko (2002) definem o empreendedorismo como uma prática possuidora de quatro componentes principais: a) Processos: podem ser gerenciados, subdivididos em partes menores, e aplicados a qualquer contexto organizacional; b) Criação de valor: os empreendedores, geralmente, criam algo onde não havia nada antes. Esse valor é criado dentro das empresas e no mercado. C) Recursos: os empreendedores utilizam os recursos disponíveis de forma singular, única, criativa. Eles combinam muito bem os recursos financeiros, pessoas, procedimentos, tecnologia, materiais, estruturas etc. Esses são os meios pelos quais os empreendedores criam valor $e$ diferenciam seus esforços; D) Oportunidade: empreendedorismo é dirigido à identificação, avaliação e captura de oportunidades de negócios.

Timmons (1994), Bateman e Snell (1998) compreendem o empreendedorismo como um ato comportamental, humano, de criatividade. Empreendedores assumem riscos calculados, tentam entender seu 
ambiente e controlar o máximo de fatores possíveis para que seu empreendimento dê certo. Para isso, utilizam sua habilidade de persuasão para formar uma equipe com conhecimentos complementares, as quais buscarão implementar e gerenciar um novo negócio ou projeto empresarial para capitalizar sobre a oportunidade identificada.

\section{MATERIAIS E MÉTODOS}

Segundo Castro (1976) e Malhotra (2001) e também, Fiorentin e Lorenzato (2009) esta pesquisa, quanto aos objetivos, é caracterizada como "exploratória ou diagnóstica", pois, houve o intuito de obter informações ou dados mais esclarecedores e consistentes sobre o tema abordado e essa modalidade de pesquisa também pode envolver o levantamento bibliográfico.

Quanto aos objetivos, a pesquisa se classifica como "descritiva", pois, propõe-se trabalhar em uma investigação declarada a respeito de um determinado assunto (COOPER; SCHINDLER, 2016), como também, se estabelecem como objetivos observar, registrar, analisar e correlacionar fatos (CERVO; BERVIAN, 2002).

Para Fachin (2006) a pesquisa bibliográfica compreende todo o levantamento das obras escritas, bem como a matéria constituída por dados primários ou secundários que venham a ser utilizados pelo pesquisador. $O$ procedimento também compreendeu a coleta de dados a entrevista semiestruturada de campo, por se tratar de técnica de extração do conhecimento direcionados por uma série de passos seguidos na realização desta pesquisa (MANZINI, 2004; KVALE; BRINKMANN, 2014) como tematização, obtenção do conhecimento, entrevista, transcrição, análise, verificação e relatórios.

Em suma, o método escolhido para a constituição do conteúdo do trabalho foi baseado em pesquisa exploratória bibliográfica apoiada por pesquisa de campo. O primeiro, foi utilizado pela necessidade de se relacionar as principais teorias administrativas, empreendedorismo e entendimento sobre microempresas, já o segundo, é aplicado devido à necessidade de comprovação prática, diante visitas a um estabelecimento, a fim de coletar informações sobre processos, pessoas e diretrizes que se dão naquele ambiente e a maneira com que são geridos.

\section{PESQUISA DE CAMPO: DESENVOLVIMENTO DAS PRÁTICAS EM UMA MICROEMPRESA}

Objetivando o maior entendimento dos conceitos abordados na disciplina de Administração Geral, no primeiro semestre do curso de Gestão Financeira da FATEC Guaratinguetá, foi proposta uma pesquisa de campo em um estabelecimento comercial (microempresa) cujas ações administrativas (gestão) deveriam ser relacionadas as teorias, assim como, deveriam ser percebidas as práticas de empreendedorismo.

As visitações ocorreram em um minimercado localizado na cidade de Guaratinguetá, o Minimercado São Gonçalo (Figura 1) e, aconteceram nos meses finais do segundo semestre de 2017 (set-out) e, dessas visitas, os autores deveriam elaborar um relatório que deveria ser apresentado formalmente em sala de aula, posteriormente.

Ficou claro que nas visitas ao estabelecimento, o intuito era também eliminar vieses advindos da gerência do local ou dos funcionários da mesma em suas atividades e, para tal, um pequeno questionário foi elaborado e aplicado. Essa técnica simplificou, então, o entendimento e o raciocínio utilizado pelo gestor (ou "dono", tratamento comum para os responsáveis por pequenas empresas) para administrar seu negócio. 
Figura 1: Planta Mercado São Gonçalo Guaratinguetá (SP)

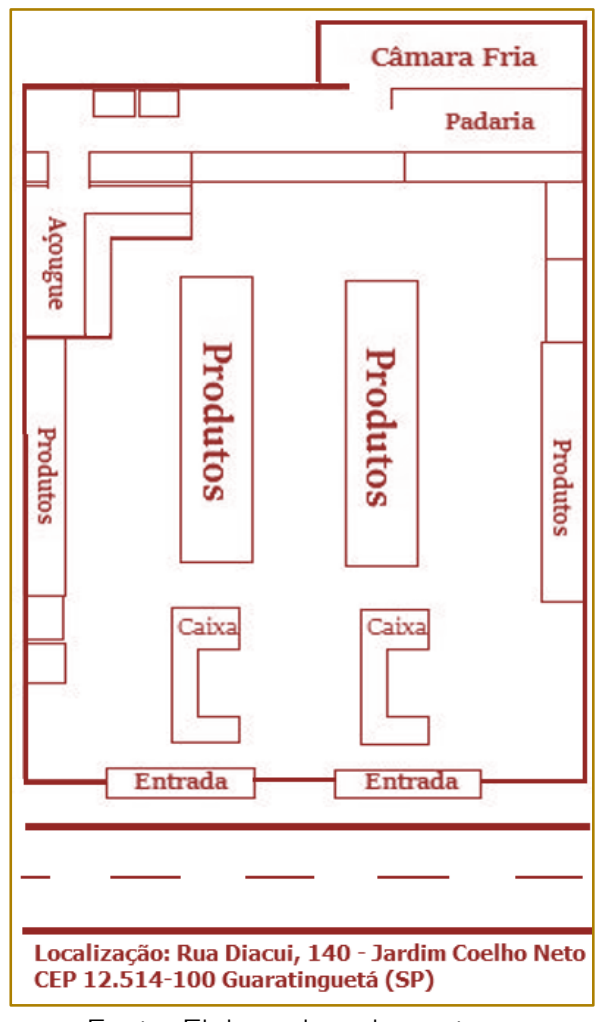

Fonte: Elaborado pelos autores

\section{RESULTADOS E DISCUSSÃO}

Em virtude dos resultados apresentados, a análise crítica e colaboração dos autores muito conferem a veracidade dos conceitos comparados às ações observadas na microempresa. A seguir, detalharam-se alguns desses exemplos.

Em geral, os resultados indicaram que uma importante referência administrativa decorrente de teorias burocráticas e classicistas são aplicadas (CHIAVENATO, 2014; MAXIMIANO, 2015; DAFT, 2017), uma vez que, o próprio gestor as associam à sua empresa quando o dono, se definiu como um "tradicionalista", declaração que já o remete as características clássico-burocrática

Ainda conforme as fontes estudadas, foi também muito perceptível os vínculos das teorias humanistas somado à ações estruturalistas (burocrático), ou seja, teorias trabalhando conectadas como propõe Drucker em seu neoclassicismo (CHIAVENATO, 2014; MAXIMIANO, 2015; DAFT, 2017), pois, de acordo com os respondentes, a cultura da empresa é baseada na importância das pessoas e de suas atitudes, entretanto, é crucial que haja o cumprimento de algumas normas pelas quais ele preza. Por exemplo, uniforme, maneira de falar e pontualidade. Há nessa gestão traços burocráticos, pois o registro de ponto dos funcionários, a contratação e qualquer procedimento é documentado para que haja transparência nas ações realizadas no mercado.

Percebeu-se que, intuitivamente, o proprietário é empreendedor e, que principalmente, aplica as práticas de inovação (MACHADO; DE CARVALHO; HEINZMANN, 2012; BRUNO-FARIA, M. F.; FONSECA, 2014; DE PAULA, 2014)., inclusive, como particularidade, ele diz que é importante que haja um forte vínculo entre cliente e funcionários, porque segundo ele o diferencial de um micro negócio é a forma cordial que são tratados os clientes. Também se tratando de humanismo, ele confirma que tenta entender as frustrações dos funcionários e durante desavenças dentro da equipe conversar com os dois lados para solucionar o problema de maneira tranquila, o que reflete a psicologia do trabalho vista em estudos e teorias das relações humanas.

Porém, a gestão não se prende apenas ao humanismo, pois o mercado, apesar de trabalhar com a centralização de poder também tem fortes tendências neoclássicas, 
uma vez que por lá, elaboram-se e perseguem-se objetivos, aplicando conceitos da referida teoria de Drucker (CHIAVENATO, 2014, DAFT, 2017).

O gestor, preocupado também em inovar e sempre trazer nova qualidade para sua empresa, procura aumentar seu conhecimento técnico através de leituras e cursos de especialização, pois, acredita que um gerente além de saber tudo o que se passa na empresa, também deve saber executar todos os processos e, quando questionado, este consegue explicar a maneira certa de se realizar o serviço, o que corrobora com os conceitos revisados de inovação (ALMEIDA, 1981; DOSI, 2006; FUZETTI, 2011). Após um treinamento rigoroso, ele aponta as direções que devem ser seguidas sem supervisão direta de sua parte, dando autonomia para que o empregado se desloque na empresa e aprenda novas funções, o que ele incentiva. Ele deseja que seus funcionários cresçam junto da empresa. Para isso, oferece cursos aos padeiros e açougueiros na intenção de deixá-los prontos a assumir uma responsabilidade maior se assim desejarem e em momentos que a contingência de clientes aumenta e o fluxo de trabalho diminui, esses funcionários possam assumir postos temporários para dar saída ao serviço. Faz-se empreender com inovação.

Ainda, percebeu-se na pesquisa que o princípio da "equidade" é um ponto muito relevante para o administrador, que procura tratar os funcionários de forma amigável e oferece salário equiparado para todos. Foi evidenciado que premiações e bonificações não estão presentes na cultura da empresa, entretanto, o método motivacional que utilizase de palavras de reconhecimento para elevar a moral da equipe traz os resultados esperados.

\section{CONSIDERAÇÕES FINAIS}

A presente pesquisa e seus frutos (como o artigo que esta gerou) é fração de um trabalho em equipe para a criação de práticas e melhor entendimento dos conceitos. Dessa análise, concluiu-se alguns pontos que serão desenvolvidos nos próximos parágrafos.
Esta pesquisa foi montada de maneira a apresentar conceitos das abordagens administrativas mais relevantes e, em seguida, exemplos práticos desses conteúdos vistos na empresa em que foi realizada a visita técnica.

Entendeu-se essa pesquisa como uma oportunidade de estudo que agrega conhecimentos a cada integrante ou autor que participou ativamente das buscas, entrevistas, da transcrição, elaboração de perguntas e também, da elaboração final ou do formato final deste documento.

O projeto não se limitou apenas à uma experiência técnica da execução de uma pesquisa exploratória de campo, ele aproximou futuros gestores e ambiente empresarial, como também, os expôs aos problemas enfrentados diariamente por empreendedores. Pode-se também notar variáveis importantes da administração como o clima organizacional, a cultura da empresa e, inclusive, relações informais entre funcionários.

Durante o registro das informações contidas neste projeto, os autores refletiram ainda, em como tornar a pesquisa mais relevante à longo prazo. Assim, surgiram diversas ideias de como melhorar o empreendimento foco. Chegou-se à conclusão que se a pesquisa fosse ainda mais extensa e completa poderia, por exemplo, entender mais a fundo as condições dos colaboradores, comparar resultados com outras empresas, definir melhor a organização formal e expandir o negócio com plano de metas voltados a inovação e empreendedorismo. Mesmo assim, a pesquisa deixou os conceitos palpáveis e aumentou a compreensão de um assunto considerado complexo através da exposição de situações-problema que envolviam esses conceitos. Em resumo, a equipe conseguiu cumprir os prazos estabelecidos e hoje, afirmar que possuem mais experiência para o entendimento da inovação e empreendedorismo, pois, aprendeu-se na prática a construir gestão estratégica-organizacional. Estão prontos para a criação de outras novas empreitadas. As teorias estudadas nesse texto puderam ser comparadas aos exemplos reais e, o método foi superior quando comparado à aprendizagem tradicional. 


\section{REFERÊNCIAS}

[1]. ALMEIDA, H. Um estudo do vínculo tecnológico entre pesquisa, engenharia, fabricação e consumo. São Paulo, 1981. 163p. Tese de Doutorado em Administração de Empresas. Escola Politécnica, Universidade de São Paulo (USP).

[2]. BATEMAN, T.; SNELL, S. Administração: contruindo vantagem competitiva. São Paulo: Atlas, 1998.

[3]. BRUNO-FARIA, M.; FONSECA, M. Cultura de Inovação: conceitos e modelos teóricos. Revista de Administração Contemporânea RAC, Rio de Janeiro, vol. 18, n. 4, art. 1, p. 372-396, 2014.

[4]. CASTRO, C. Estrutura e Apresentação de Publicações Científicas. São Paulo (SP): McGrawHill, 1976.

[5]. CERVO, A.; BERVIAN, P. Metodologia Científica. 5a․ Ed. São Paulo: Prentice Hall, 2002.

[6]. CHIAVENATO, I. Introdução À Teoria Geral da Administração. 9ạ. Ed. Barueri (SP) Manole, 2014

[7]. COOPER, D.; SCHINDLER, P. Métodos de Pesquisa em Administração. 12a. ed. Porto Alegre: Bookman, 2016.

[8]. DAFT, R. Administração. Trad. da 12a . Ed. Norte-Americana. São Paulo: Cengage, 2017.

[9]. DÁVILA, G. ; LEOCÁDIO, L.; VARVAKIS, G. Inovação e Gerenciamento de Processos: uma análise baseada na gestão do conhecimento. DataGramaZero. Revista de Ciência da Informação. vol. 9, n.3, 2008.

[10]. DE PAULA, C. Análise do Grau de Inovação das Micro e Pequenas Empresas do Segmento Alimentício Atendidas pelo Programa Agentes Locais de Inovação na Região Oeste do Estado de Goiás. 2014. Dissertação (Mestrado em Administração) Faculdade Alves Faria, Goias (GO), 2014.

[11]. DORNELAS, J. Empreendedorismo corporativo: como ser empreendedor, inovar e se diferenciar em organizações estabelecidas. Rio de Janeiro. Elsevier, 2003.

[12]. DORNELAS, J. Empreendedorismo Corporativo: Conceitos e Aplicações. RN Revista de Negócios. Blumenau, v. 9, n. 2, p. 81-90, abril/junho 2004.

[13]. DOSI, G. Technological paradigms and technological trajectories. In: Revista Brasileira de Inovações, vol. 5, n. 1, p. 17-32, 2006.

[14]. DRUCKER, P. Inovação e Espírito Empreendedor: práticas e princípios. Ed. Rev. São Paulo: Cengage Learning, 2016.

[15]. FACHIN, O. Fundamentos de Metodologia. 5a. Ed. São Paulo (SP): Saraiva, 2006.

[16]. FIORENTINI, D.; LORENZATO, S. Investigação em Educação Matemática. Coleção
Formação de Professores. 3르. Ed. Campinas (SP): Editora Autores Associados, 2009.

FREEMAN, C.; SOETE, L. The Economics of Industrial Innovation. 3a. Ed. Routledge, Abingdon, Oxon UK, 1997

[18]. FUZETTI, D. A Realização de Novas Combinações no Setor Empresarial e o Empreendedor. 9o Congresso de Pós-Graduação. Mostra Acadêmica UNIMEP Piracicaba (SP). 2011. Disponível em: <http://www.unimep.br/phpg/mostraacademica/ana is/9mostra/5/192.pdf>. Acesso em: 26/02/2018.

[19]. KVALE, S.; BRINKMANN, S. InterViews: learning the craft of qualitative research interviewing. 3a. Ed. SAGE Publications, 2014

[20]. LARA, J. E. Estado de La Consultoria Organizacional Externa em PYMES de São Paulo Brasil. Tese (Doutorado) Universidade Autônoma de Barcelona, Barcelona, Espanha, 1993.

[21]. LEHNER, M.; HALLIDAY, S. Branding sustainability: opportunity and risk behind a brandbased approach to sustainable markets. Ephemera Journal: theory \& politics in organization. vol. 14, n. 1, p. 13-34, 2014.

[22]. LEONE, N. A Dimensão Física das Pequenas e Médias Empresas P.M.E's: à procura de um critério homogeneizador. Revista de Administração de Empresas, vol.31, n. 2, p.53-59, 1991.

[23]. MACHADO, D.; DE CARVALHO, L.; HEINZMANN, L. Ambiente favorável ao desenvolvimento de inovações e cultura organizacional: integração de duas perspectivas de análise. Revista de Administração. São Paulo, vol.47, n.4, p.715-729, 2012

[24]. MANZINI, E. J. Entrevista: definição e classificação. Marília: Unesp, 2004.

[25]. MAXIMIANO, A. Introdução a Administração. São Paulo: Atlas, 2015.

[26]. MENDES, J. ; ESCRIVÃO FILHO, E. Atualização tecnológica em pequenas e médias empresas: proposta de roteiro para aquisição de sistemas integrados de gestão (ERP). Gestão \& Produção. São Carlos, vol. 14, n. 2, p. 281-293, 2007.

[27]. MORRIS, M.; KURATKO, D. Corporate Entrepreneurship - Entrepreneurial Development within Organization. Thomson South-Western, Boston, USA, 2002.

[28]. PLONSKI, G. A. Bases para um Movimento pela Inovação Tecnológica no Brasil. São Paulo em Perspectiva. vol.19 n.1, 2005.

[29]. RIBEIRO, M.; MILANI, C. Compreendendo a complexidade socioespacial contemporânea: o território como categoria de diálogo interdisciplinar. Salvador: EDUFBA, 2009. 
[30]. SCHUMACHER, E. F. O Negócio é Ser Pequeno. Rio de Janeiro (RJ); Zahar, 1977.

[31]. SEBRAE. Serviço Brasileiro de Apoio Às Micro e Pequenas Empresas. Cadernos de Inovação em Pequenos Negócios: Engenharia, Tecnologia e Energia. Brasília (DF): SEBRAE, Vol. 2, N. 2, 2014.

[32]. SILVA, D. O.; BAGNO, R. B.; SALERNO, M. S. Modelos para a Gestão da Inovação: revisão e análise da literatura. Production, vol. 24, n. 2, p. 477-490, 2014

[33]. STALEY, E. Small Industry Development. Research Program on Small Industry Development. Stanford Research Institut, paper n. 1, 1958.
[34]. TAKEUCHI, H.; NONAKA, I. Gestão do Conhecimento. Porto Alegre (RS): Bookman, 2008.

[35]. TIMMONS, J. New Venture Creation: Entrepreneurship for 21st Century. $4^{\mathrm{a}}$. Ed. Chicago, IL: Irvin McGraw-Hill, 4ª . Ed., 1994.

[36]. VAN DE VEN, A. H.; ANGLE, H. L.; POOLE, M. S. (Orgs). A Methods for Studying Innovation Processes. In.: Research on the management of innovation. New York: Oxford University Press, 2000.

[37]. ZANELLA, W.; FRÂNCIO, S.; AGOSTINI, M. R.; RECH, E. A inovação sob a visão dos gestores de duas Instituições públicas. ReFAE Revista da Faculdade de Administração e Economia, vol. 4, n. 1, p. 107-127, 2012. 


\section{Capítulo 8}

\section{MARKETING PARA NICHOS DE MERCADO: RAMO DAS CERVEJAS ARTESANAIS NO BRASIL}

\section{Anderson Marques dos Santos}

\section{Luciano Gonçalves Costa}

\section{Isabel Cristina Mota}

Resumo: O objetivo deste estudo é mostrar a importância do marketing de nicho em um ramo de mercado segmentado, que é o caso das cervejas artesanais, seja para fidelizar ou atrair novos consumidores. Para descobrir o perfil dos consumidores foi necessária uma pesquisa de campo de natureza quantitativa, pesquisa que foi compartilhada nas redes sociais e através dela pode-se concluir que os principais clientes são adultos, acima dos 25 anos e que procuram qualidade e variedade nesses produtos. $\mathrm{O}$ uso das ferramentas de marketing para este ramo torna-se atrativo, pois é um segmento em alta e que tende a tornar microcervejarias em grandes cervejarias.

Palavras-chave: Marketing de nicho. Cerveja artesanal. Consumidores. 


\section{INTRODUÇÃO}

Para entender o marketing de nicho é necessário compreender o conceito de nicho. O nicho de mercado seria, basicamente, um mercado segmentado para um público específico. Exemplos de nicho: loja de doces para diabéticos, mercados que vendem apenas produtos orgânicos, lojas de roupa especializadas em modelos plus size, sapatarias especializadas em calçados ortopédicos, dentre outros exemplos.

O ramo da cerveja artesanal pode ser considerado um nicho, pois atrai um públicoalvo específico, isso é um público segmentado. Neste ramo, o público majoritário é a classe $A$ e $B$, isso se deve ao fato do público da classe $C$ optar por marcas industrializadas e com preços acessíveis, em detrimento da classe $A$ e $B$ que preferem produtos diferenciados.

Embora seja um mercado altamente segmentado, este ramo tem crescido bastante nestes últimos anos, seja pela motivação empreendedora ou pelo aumento do poder aquisitivo dos consumidores.

Através do marketing para nichos de mercado é possível atrair novos consumidores para este segmento e fazer com que enxerguem além do alto custo, também perceba o valor no produto.

\section{EMBASAMENTO TEÓRICO}

No embasamento teórico serão abordados alguns contextos de marketing, como: segmentação de mercado, marketing de nicho, comportamento do consumidor e o valor de um produto para o cliente, além da história e o cenário da cerveja artesanal.

\subsection{SEGMENTAÇÃO DE MERCADO}

Conforme Kotler e Keller (2012) segmento de mercado significa um conjunto de consumidores que compartilham, similarmente, as necessidades ou desejos. Essa segmentação é feita de quatro formas: geográfica, demográfica, psicográfica e comportamental.

A segmentação geográfica leva em consideração: países, estados, bairros, cidades, dentre outras formas geográficas. Por sua vez a demográfica, consiste em variáveis como: idade, renda, sexo, classe social, entre outras variáveis. Já a psicográfica está relacionado à personalidade, percepções, estilo de vida, dentre outros aspectos. A segmentação por comportamento seria os hábitos e influências do cliente no momento da compra.

A segmentação é um dos primeiros passos para a divisão do mercado, após a segmentação vem a seleção do mercadoalvo. Para Hisrich, Peters e Shepherd (2014, p. 193): "Grupo específico de possíveis clientes para os quais o empreendimento direciona seu plano de marketing". Feito a escolha do mercado-alvo vem o posicionamento de mercado, que seria a forma como a empresa se posicionaria com base nas informações de segmentação e do mercado-alvo.

O marketing de nicho ou marketing concentrado seria um dos quatro níveis de segmentação que também é composta pelo marketing de massa, marketing de segmento e marketing individualizado.

\subsection{MARKETING DE NICHO}

O marketing possui diversas áreas, e embasando-se nessa informação não se pode deixar de citar o marketing de nicho. Basicamente, trata-se de uma ramificação do marketing que visa estabelecer um produto ou serviço com características exclusivas, voltado para um público específico. As empresas que atuam nessa área concentram seus esforços em clientes especiais, o que do conceito de produção em larga escala, pois com esse foco conseguem satisfazer com mais facilidade seu target minoritário, porém lucrativo, e esse tipo de público é considerado um nicho de mercado. Geralmente, a partir do momento que uma empresa torna-se capaz de atender clientes exclusivos, repassa isso para o preço final do produto, que acaba tornando-se alto, porém quem paga por isso sabe que se trata de um produto/serviço que foi produzido/realizado com a finalidade de satisfazer unicamente suas necessidades diferenciadas, e que há um trabalho mais cauteloso para alcançar isso.

O consumidor que possui necessidades especiais em relação a um produto é completamente suscetível a tornar-se um cliente fidelizado de uma empresa atuante no mercado de nichos, então por esse motivo muitas empresas estão surgindo com os 
objetivos voltados a atuar nesse mercado diferenciado.

Segundo Kotler e Armstrong (1997, p. 422), as características fundamentais de um nicho atraente são:

- O conjunto de necessidades distintas que cada cliente possui;

- O preço alto que os clientes estão dispostos a pagar para a empresa que melhor satisfazer suas necessidades;

- A ausência de concorrentes em potencial;

- A capacidade de alta rentabilidade por meio da especialização.

Por mais rentável que seja atuar em um mercado de nichos, também pode se tornar um risco em alguns casos, justamente por se tratar de um esforço concentrado em uma área específica, pois a partir do momento que o produto ou serviço perder sua tendência e participação no mercado a empresa que se concentra nessa área acaba se prejudicando se não possuir outras áreas de atuação.

Fica claro o quão importante é a satisfação do cliente quando se trata do mercado de nichos, e os esforços que as empresas empenham para causar essa reação positiva de satisfação desse público minoritário e alta rentabilidade ao mesmo tempo.

\subsection{COMPORTAMENTO DO CONSUMIDOR}

Para Sheth, Mittal e Newman (2000, p. 29): "O comportamento do consumidor é definido como as atividades físicas e mentais realizadas por clientes de bens de consumo e industriais que resultam em decisões e ações, como comprar e utiliza produtos e serviços, bem como pagar por eles."

Para Kotler (2000a, p. 183): "O comportamento de compra do consumidor é influenciado por fatores culturais, sociais, pessoais e psicológicos. Os fatores culturais exercem a maior e mais profunda influência." Adiante serão abordados os quatros fatores.

Qualquer estratégia de marketing, bemsucedida, precisa considerar esses fatores, que influenciam no comportamento do consumidor.

\subsubsection{FATORES CULTURAIS}

Estão relacionados a valores, crenças e preferências de um público. Esses fatores são adquiridos conforme o ambiente inserido.

Dentro da cultura, existe o que se denomina subcultura, que seriam algumas variáveis como: religião, etnia, localidade geográfica, entre outras variáveis.

No caso da cerveja artesanal, a maior produção dela está concentrada nas regiões Sul e Sudeste do Brasil, por inúmeros fatores, dentre eles a imigração alemã nessas regiões, principalmente no Sul do Brasil.

\subsubsection{FATORES SOCIAIS}

Este fator está relacionado à família, status, grupos de referência, entre outras. Neste caso muitos consumidores passam a consumir a bebida graças as indicações desses grupos de referência.

\subsubsection{FATORES PESSOAIS}

Idade, personalidade, estilo de vida, autoimagem, etc. O consumo de cervejas artesanais, em ocasiões especiais, passa a fazer parte do estilo de vida dos clientes.

\subsubsection{FATORES PSICOLÓGICOS}

Os principais fatores psicológicos são: motivação, percepção, atitudes e aprendizagem. O que motiva novos clientes a consumir cerveja artesanal é justamente a curiosidade e através desta curiosidade, o consumidor passa a perceber a qualidade empregada na bebida.

\subsection{VALOR PARA O CLIENTE}

Muitos afirmariam que se trata do preço que se paga em um produto. Mas será essa a definição correta?

Segundo Barnes (2002, p.100): "valor envolve uma disposição favorável, um gosto, um afeto positivo ou um julgamento de algo como bom". Ou seja, inconscientemente as pessoas relacionam valor com o preço a ser pago, porém trata-se de algo que está implantado no subconsciente, é uma ligação íntima que certos produtos conseguem manter com o cliente, e para entregar valor, as empresas devem entender como seu público-alvo se 
comporta perante as características do produto a ser comercializado.

Para Kotler (2000b, p. 33): "o produto ou oferta alcançará êxito apenas se proporcionar valor e satisfação ao comprador-alvo". Tratase de um assunto delicado para as empresas, justamente pela percepção diferente de cada pessoa, o que é valor para um pode não ser para o outro. Muitas empresas concentram seus esforços em aspectos restritos com o objetivo de satisfazer seu público-alvo, pois se as expectativas do cliente não forem atendidas ao adquirir 0 produto, provavelmente ele não retornará para realizar uma nova aquisição.

Um exemplo que se encaixa perfeitamente nessa definição de valor para o cliente é o consumo de cervejas. Quando se trata de uma cerveja industrializada em larga escala (pilsen e chope), os clientes valorizam principalmente o momento em que irá consumi-la, geralmente em festas e reuniões entre amigos ou familiares, e nessas ocasiões o que é levado em consideração é o preço baixo, ou seja, buscam o preço mais baixo para que haja uma compra em grandes quantidades, suficientes para suprir as necessidades de todas as pessoas na ocasião.

Seguindo pela mesma linha de produtos, existe outro segmento das cervejas, as artesanais/premium. Já nesse contexto a definição de valor torna-se muito diferente do exemplo anterior, pois o cliente que busca a cerveja artesanal não dá importância ao fator "preço", o que realmente importa é a relação custo/benefício, então quantidade não é o que importa nesse caso, mas sim qualidade.

Uma microcervejaria artesanal, por exemplo, ao tentar desenvolver estratégias para que haja expansão de seu público apreciador, deverá agir acerca de estratégias que influenciem inconscientemente as pessoas a adquirir o produto pelo fator qualidade, sem que seja levado em consideração o alto custo, pois é algo característico no ramo por questão de altos impostos.

\subsection{HISTÓRIA DA CERVEJA}

De acordo com o Decreto no 6.871 (2009, s.p.): "Cerveja é a bebida obtida pela fermentação alcoólica do mosto cervejeiro oriundo do malte de cevada e água potável, por ação da levedura, com adição de lúpulo."
Perozzi e Beaune (2014) afirmam que o mosto é a cerveja antes do processo de fermentação.

A chegada da bebida no Brasil aconteceu no século XVII, com a colonização holandesa, porém com saída deles, a cerveja só reapareceu no final do século XVIII.

A partir de 1808 inúmeros comerciantes estrangeiros, principalmente ingleses, instalaram-se no Brasil, fazendo vir da Europa, entre outros produtos, a cerveja. Caberia lembrar a grande influência comercial (e consequentemente cultural) da Inglaterra, na época, sobre Portugal, bem como início do século XIX, a Inglaterra era, de longe, a maior produtora de cerveja da Europa. (SANTOS, 2003, p. 12)

Não há uma origem precisa de quando começou o desenvolvimento de cervejas especiais ou artesanais, mas convém destacar, nos Estados Unidos, a história de Fritz Maytag (1937-), formado em letras na Universidade de Stanford.

Na década de 1960, o recém-formado Fritz Maytag, amante de cervejas artesanais, principalmente a Anchor Steam ${ }^{\circledR}$ Beer, se tornou sócio da cervejaria americana Anchor Brewing Company, fundada em 1896, que estava fadada ao fracasso na década de 1960. Após adquirir a cervejaria americana e reestruturar a produção, a infraestrutura e os equipamentos, em pouco tempo, a cervejaria se reergueu e em 2010 foi vendida ao The Griffin Group. Por esse espírito empreendedor, Fritz Maytag é considerado o "pai" da cerveja artesanal moderna.

\subsection{O CENÁRIO DA CERVEJA ARTESANAL}

Em território nacional, o ramo das cervejas artesanais vem crescendo de forma considerável. Segundo a Associação Brasileira de Cerveja Artesanal (ABRACERVA), o número de cervejarias artesanais com registro evoluiu em cerca de 10\% desde o início de 2017 e a maioria das fábricas se concentra nas regiões Sul e Sudeste, e ações locais promovidas por essas cervejarias contribuem cada vez mais para o crescimento do setor.

É evidente o grande esforço que as microcervejarias artesanais empenham em território nacional para que as demandas sejam atendidas e ocorra também a fidelização de seus clientes. Exemplo claro de 
tais esforços é a presença de algumas marcas em eventos cervejeiros realizados em locais específicos e também a possibilidade da degustação de seu produto na própria fábrica, com o objetivo principal de levar a cultura da cerveja artesanal para novos públicos e também consolidar ainda mais o setor no mercado cervejeiro. Esse tipo de relação faz com que a marca obtenha um maior número de apreciadores e fidelize seus clientes, o que por consequência aumenta sua rentabilidade e abre novos horizontes para investimentos.

Envolvida nesse conceito, a cervejaria de Campos do Jordão chamada Baden Baden pode ser citada como exemplo, pois promove em sua fábrica visitas com possibilidade de degustação no local, além de ter um restaurante em suas dependências que disponibiliza todo o seu portfólio para os clientes e visitantes mantendo sempre a qualidade em suas bebidas, isso fez com que sua popularidade no município aumentasse cada vez mais, até que se tornou ponto turístico, e em 2007 devido a sua grande visibilidade, foi adquirida pela Schincariol que após cinco anos tornou-se a Brasil Kirin. A marca Baden Baden foi preservada, porém a sua força de distribuição estava maior e passou a alcançar outros estados e municípios, o que gerou inúmeras vantagens para a empresa. Recentemente um movimento ainda maior ocorreu, pois em 2017 a Heineken adquiriu a Brasil Kirin, e com isso assumiu controle total das marcas pertencentes a ela, então se torna evidente o quanto a Baden Baden ainda crescerá nacionalmente e internacionalmente, mantendo sempre sua característica de cerveja artesanal.

Mesmo com todo esse potencial de crescimento, as microcervejarias possuem certas barreiras em território nacional que impedem a rápida expansão do ramo, e a principal barreira é a alta taxa de impostos repassada para os empreendedores do ramo. Segundo o Instituto da Cerveja Brasil, sempre que o consumidor final compra uma cerveja artesanal no Brasil, 57\% do valor corresponde a impostos. Trata-se de um número assustador, mas a única forma de conviver com isso é repassar um preço final que compense a alta taxa de impostos. Para o cliente que conhece a qualidade de uma cerveja artesanal, o preço final não possui influência alguma, porém a grande preocupação é: Como atrair novos públicos que considerem o preço como uma variável importante, evidenciando apenas os benefícios da cerveja artesanal?

\section{PESQUISA DE CAMPO - EMPORIO QUINTAL DA VÓ}

Com base nos assuntos tratados até o momento, foi realizada uma visita em um estabelecimento especializado na venda de cervejas e chopes artesanais. A finalidade da visita foi pesquisar as tendências desse mercado e entender quais os objetivos da microempresa.

O estabelecimento localiza-se no bairro nobre da Mooca, na zona leste de São Paulo, e seu ramo de atuação são cervejas, chopes, petiscos e lanches artesanais, que por sinal é uma grande tendência no mercado atual. Trata-se de um ambiente com uma boa decoração, com trilha sonora clássica, que proporciona aos clientes a sensação de estar um local familiar, e isso é importante para quem atua neste nicho, pois o que conta nesse cenário é a satisfação total do cliente com os serviços prestados e a sensação de ser alguém especial para a empresa.

A divulgação do estabelecimento é realizada através de redes sociais, sites voltados para divulgação de empresas e pontos turísticos, e também o marketing boca a boca realizado por clientes fidelizados do estabelecimento

O primeiro contato com o local foi através da apresentação do ambiente por parte de uma das proprietárias, logo em seguida a escolha de uma mesa para a acomodação e o recebimento dos cardápios. A partir daí a primeira impressão já surgiu, tratava-se de um ambiente específico para um nicho de mercado, um público diferenciado. Como o principal objetivo era realizar uma pesquisa, no momento do recebimento das bebidas (Chopes artesanais) e dos lanches (Sanduíches com hambúrguer artesanal e especiarias), foi solicitado à proprietária que respondesse, humildemente, algumas perguntas com fins acadêmicos, e o pedido foi aceito.

Primeiramente, era necessário entender, oficialmente, qual era o público-alvo do estabelecimento, e como esperado, foi respondido que o público-alvo se baseia em pessoas de 35 a 50 anos sendo integrantes das classes $A$ e $B$, pois são mais propensos a apreciar cerveja artesanal e especiarias 
servidas no local, são clientes especiais que buscam variedade e diferenciação em um produto ou serviço.

A segunda pergunta realizada foi em relação ao maior desafio para a empresa, e nesse ponto foi evidenciado pela proprietária que manter-se firme em um ramo onde altos custos são exigidos não é fácil, pois é importante sempre haver demanda de clientes dispostos a pagar pelo preço final dos produtos e serviços oferecidos, ou seja, fidelizar os clientes e fazê-los enxergar o valor agregado no produto ou serviço.

A terceira pergunta foi voltada a planos futuros de expansão, e na resposta ficou claro o quanto se preocupam em cuidar do atual ambiente para que haja maior atratividade, isso a curto e médio prazo. Foram realizadas reformas internas no último ano, e também a implantação de um espaço kids, pois os proprietários observavam a quantidade expressiva de casais com crianças que frequentam o local. Em longo prazo existem sim alguns planos de expansão, porém o foco da empresa ainda não é esse, e isso é característico de muitas empresas atuantes no mercado de nichos.
As perguntas realizadas foram a chave para entender a forma de atuação de uma empresa focada em nichos de mercado, e para aprofundar mais ainda a pesquisa foi disseminado um questionário para os consumidores de cerveja artesanal.

\section{DESENVOLVIMENTO DA TEMÁTICA}

Foi realizada uma pesquisa quantitativa em uma amostra de 53 pessoas divididas entre as regiões Sul e Sudeste do Brasil, e tal pesquisa foi compartilhada principalmente na rede social, em grupos fechados para consumidores e produtores de cerveja artesanal.

\section{RESULTADOS E DISCUSSÃO}

O primeiro gráfico trata-se da separação por sexo e idade dos consumidores de cerveja artesanal. É notável a maior inclinação do público masculino com idade partindo dos 36 aos 41 anos, sendo boa parte também concentrada acima dos 41 anos. E justamente esse público o maior consumidor da bebida.

Gráfico 1 - Sexo e idade

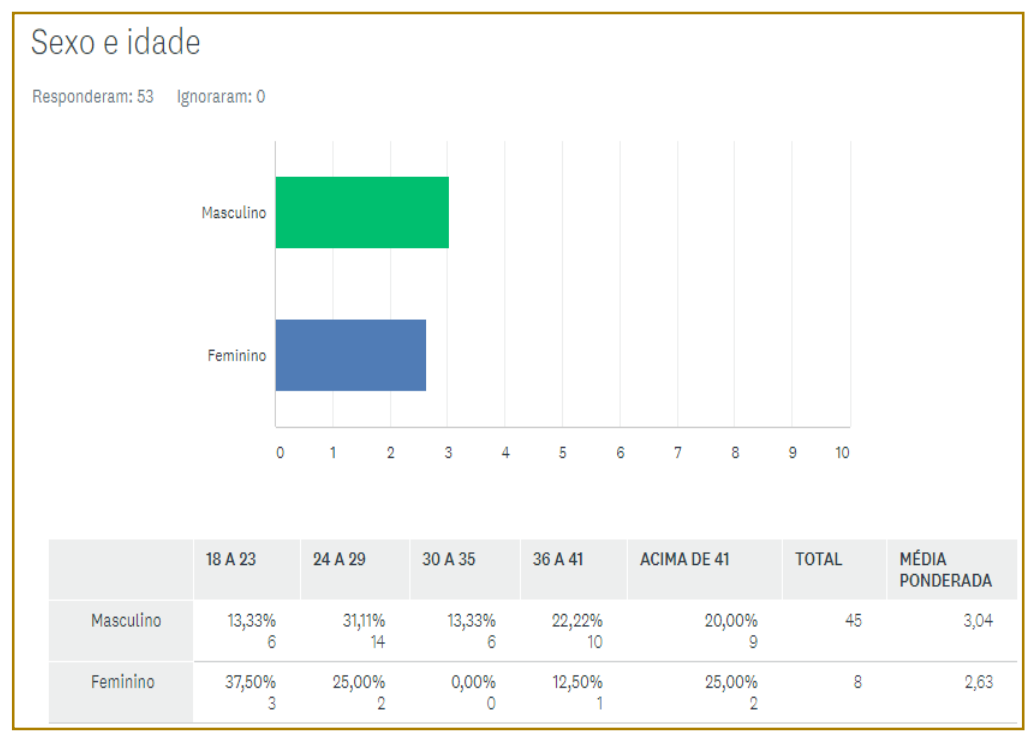

Fonte: Elaborado pelos autores.

No segundo gráfico, encontram-se as informações relacionadas a preferência por marcas, e a Baden Baden segue liderando com 53,85\% na preferência dos consumidores, logo em seguida a Eisenbahn com 48,08\% e a Colorado com 46,15\%.
Analisando esses resultados, pode-se entender o quão importante foi a expansão dessas marcas através da interferência de grandes empresas como a Ambev e o grupo Heineken. 
Gráfico 2 - Marcas preferidas

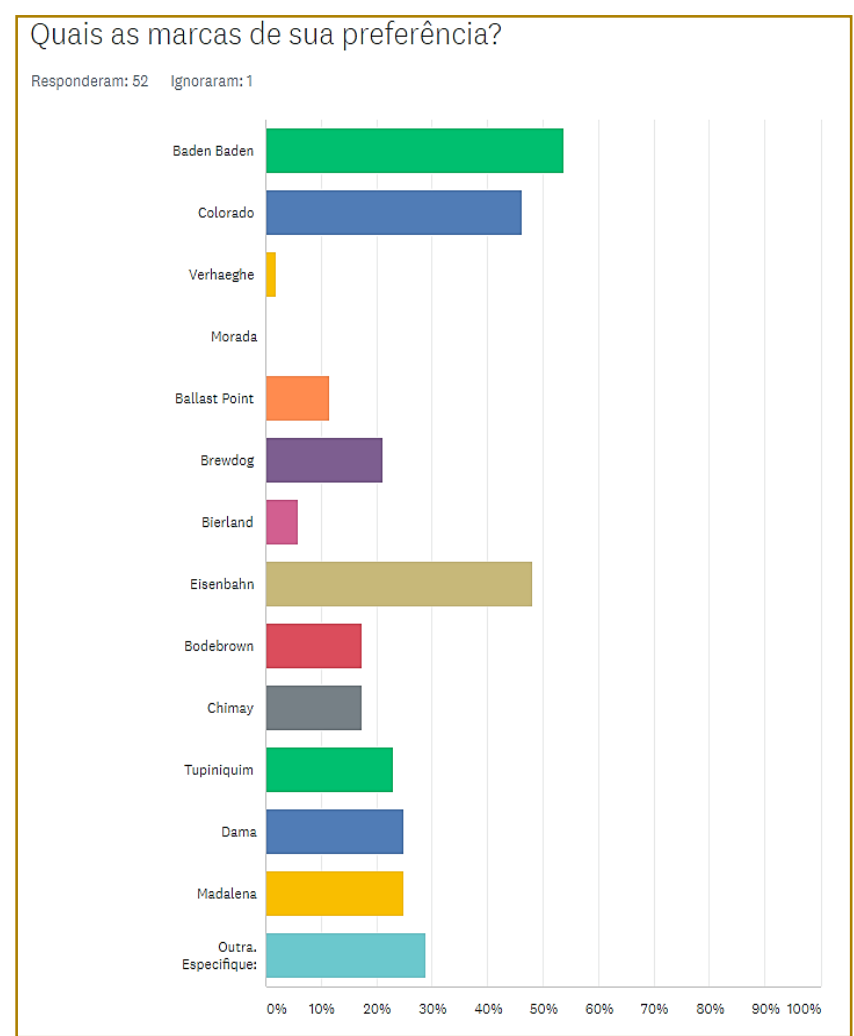

Fonte: Elaborado pelos autores.

O terceiro e último gráfico é importante, pois é aonde está evidenciado o diferencial que o consumidor enxerga na cerveja artesanal, e o quesito qualidade foi definido por mais de $80 \%$ dos respondentes, seguido da variedade de sabores $(60,38 \%)$ e curiosidade $(18,87 \%)$.

Gráfico 3 - O que diferencia uma cerveja artesanal

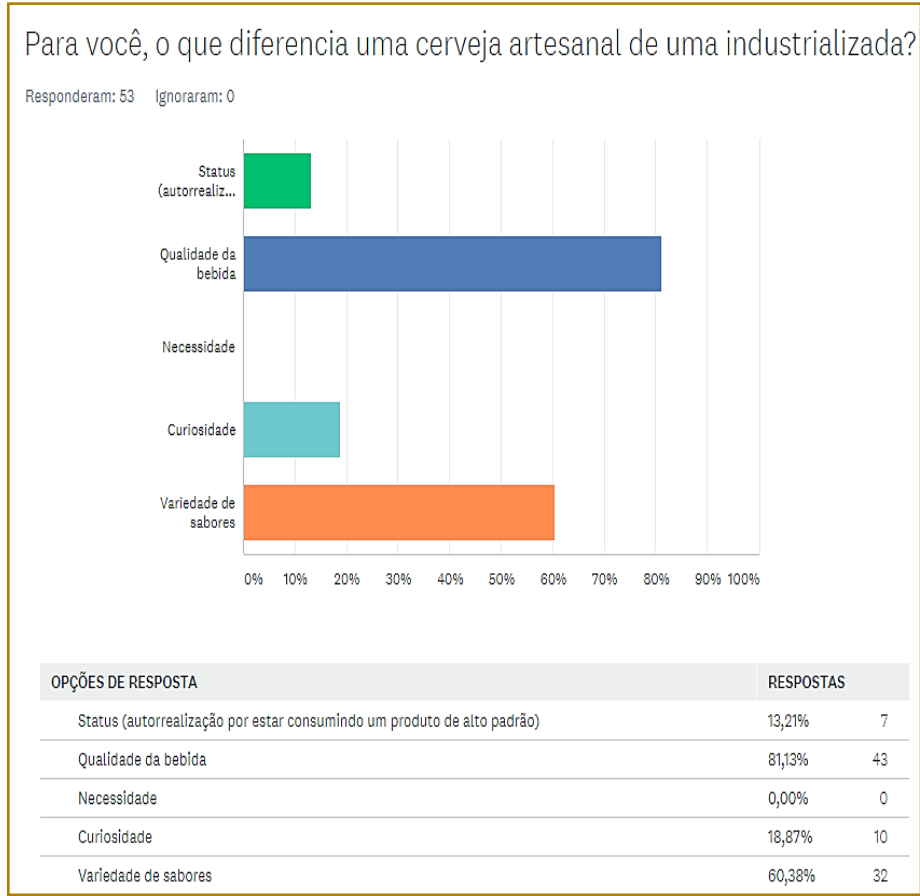

Fonte: Elaborada pelos autores 


\section{CONSIDERAÇÕES FINAIS}

Ao longo deste trabalho de pesquisa, foi perceptível o quanto o marketing de nicho é uma estratégia que realmente funciona no ramo das cervejas artesanais. Trata-se de um mercado seletivo que necessita de atenção especial, pois é um público inclinado ao consumo de um produto com alto custo, portanto deve entregar ao cliente um valor agregado positivo e alta qualidade.

Como visto na pesquisa de campo ao Empório Quintal da Vó, o foco dos próprios empresários que atuam nesse ramo é proporcionar ao cliente um ambiente satisfatório, com atendimento diferenciado, variedade de cervejas artesanais e conforto de alto padrão, pois como trata-se de um nicho de mercado, a empresa consegue manter um foco maior no público em que deseja atender, entendendo quais as necessidades específicas e desejos desse cliente. Um grande exemplo são os alimentos servidos no local, que são de preparo artesanal, de forma que combinem com cada tipo de cerveja disponibilizada ao cliente, levando maior conforto e seletividade para quem consome esses produtos em conjunto, e entra mais uma característica de um nicho de mercado, a empresa pensa em estratégias de acompanhamento para a cerveja artesanal e entende que o cliente que consome esse tipo de bebida é propenso a consumir também alimentos com preparo especial para tal ocasião.

A tendência para o crescimento desse ramo segue positiva, tanto que algumas cervejarias

\section{REFERÊNCIAS}

[1]. ABRACERVA. Em cinco meses, Brasil registra 65 novas cervejarias artesanais. 2017. Disponível em: <http://abracerva.com.br/em-cincomeses-brasil-registra-65-novas-cervejarias-

artesanais/>. Acessado em: 16 de março de 2018, $15 \mathrm{~h} 38 \mathrm{~min}$

[2]. BARNES, James G. Segredos da Gestão pelo Relacionamento com os clientes. Rio de Janeiro: Qualitymark, 2002. 400 p.

[3]. DECRETO no 6871 , de 4 de junho de 2009. Regulamenta a Lei $n^{\circ} 8.918$, de 14 de julho de 1994, que dispõe sobre a padronização, a classificação, o registro, a inspeção, a produção e a fiscalização de bebidas. Disponível em: <http://www.planalto.gov.br/ccivil_03/_ato20072010/2009/decreto/d6871.htm>. Acessado em: 18 de março de 2018, 13h15min. que tinham como objetivo inicial atender a um pequeno nicho mantiveram um foco tão grande que passaram a ser reconhecidas de forma rápida e expandiram-se para outros territórios nacionais através de grandes empresas de bebidas que as adquiriram. Os maiores exemplos dessa expansão são as Cervejarias Baden Baden, que como descrito no artigo pertence atualmente à Heineken, e a Colorado que pertence a Ambev.

Para boa parte dos empresários atuantes nesse ramo, talvez suas projeções se baseiem apenas ao atendimento em um local específico com um público também específico, isso é uma característica chave do marketing de nicho, porém quando todos os objetivos são realizados e a satisfação total é levada aos clientes, automaticamente a tendência de crescimento do negócio é ampliada, é nesse momento que podem surgir grandes empresas com interesse em parcerias e até em adquirir a marca para que haja expansão para outros territórios, e podese dizer que esse é uma grande oportunidade para qualquer microcervejaria.

O objetivo desse trabalho foi evidenciar a importância e o quão rentável é atuar em um mercado concentrado, especialmente o mercado das cervejas artesanais que, a cada ano que passa, obtém maior reconhecimento e fatia do mercado nacional. Para isso, foi fundamental avaliar o comportamento dos consumidores através de pesquisas, e entender como é a participação deles em toda a cadeia relacionada ao marketing de nicho da cerveja artesanal.

[4]. HISRICH, Robert D.; PETERS, Michael P.; SHEPHERD, Dean A. Empreendedorismo. - 9. ed. - Tradução Francisco Araújo da Costa. São Paulo: Bookman, 2014. 472 p.

[5]. INSTITUTO DA CERVEJA BRASIL. Guia completo: entenda como está o mercado de cervejas no Brasil. 2017. Disponível em: <https://d335luupugsy2.cloudfront.net/cms/files/25 397/1507159708eBook_Guia_Completo_Entenda_ Como_Esta_o_Mercado_Cervejeiro_no_Brasil.pdf>. Acesso em: 07 de março de 2018, 14h27min.

[6]. KOTLER, Philip; ARMSTRONG, Gary. Princípios de marketing. Rio de Janeiro: Prentice Hall, 2008. 600 p.

[7]. _. Administração de marketing - 10. ed., $7^{a}$ reimpressão - Tradução Bazán Tecnologia 
e Lingüística; revisão técnica Arão Sapiro. São Paulo: Prentice Hall, 2000a. 764 p.

[8]. Administração de marketing: a edição do novo milênio. São Paulo: Prentice Hall, 2000b. 764 p.

[9]. _ KELLER, Kevin Lane. Administração de marketing - 14. ed. - Tradução Sônia Midori Yamamoto; revisão técnica Edson Crescitelli. São Paulo: Pearson Education do Brasil, 2012. 762 p.
[10]. PEROZZI, Christina; BEAUNE, Hallie. Cerveja em casa. São Paulo: Tapioca, 2014. 320 p.

[11]. SANTOS, Sérgio de Paula. Os primórdios da cerveja no Brasil - 2. ed. Cotia: Ateliê Editorial, 2003. $51 \mathrm{p}$.

[12]. SHETH, Jagdish N.; MITTAL, Banwari; NEWMAN, Bruce I. Comportamento do cliente. São Paulo: Atlas, 2001. 795 p. 


\section{Capítulo 9}

\section{O USO DA SIMULAÇÃO PARA MELHORIAS NOS PROCESSOS E ATENDIMENTO AO CLIENTE: ESTUDO DE CASO EM UMA PET SHOP}

\section{Cristiane da Silva}

\section{Luciano Geraldo da Silva}

Peri da Silva Santana

Resumo: A simulação é um método utilizado para criar um modelo de um sistema real e, através do uso do computador é possível realizar diversas modificações no cenário com o objetivo de se obter uma visão geral de possíveis gargalos e a visualização de um melhor dimensionamento do sistema sem a necessidade de fazer isso em escala real que geraria um alto custo. Utilizando o software Arena, este artigo tem o objetivo de simular um cenário real de uma empresa do setor especializada na saúde de animal e identificar possíveis gargalos. A análise feita através do software Arena, em todos os processos incluindo a agenda, foi possível identificar problemas e propor melhorias de acordo com os relatórios que vão sendo gerados. Após análise dos dados obtidos com a pesquisa de campo e uso do software Arena os resultados apontaram o tempo de agendamento como o gargalo operacional da Pet Shop, com as médias obtidas com a pesquisa foi proposto um remanejo nos horários de agendamento, e padronização do conforme o tamanho do animal e a cor do pelo.

Palavras-chave: Arena, Cenário, Simulação e Padronização. 


\section{INTRODUÇÃO}

A simulação ganha cada vez mais destaque no meio empresarial como eficiente ferramenta no auxilio da tomada de decisão nas pequenas e grandes empresas; e o gestor deste novo cenário competitivo não pode ficar alheio diante de tal realidade, a operação atual exige ações eficientes voltadas ao aumento produtivo e redução dos custos, com a possibilidade de previsão de perdas e resolução de problemas evitando desperdício e maximizando o lucro.

O objetivo deste trabalho de pesquisa é levantar as razões e os principais problemas enfrentados na operação da Pet Shop e, encontrar meios de como atender os clientes de forma eficiente e satisfatória, localizar as restrições ao uso e propor melhorias.

De acordo com Pegden (1995), a simulação é um processo de projetar um modelo computacional de um sistema real e conduzir experimentos com este modelo com o propósito de entender seu comportamento e/ou avaliar estratégias para sua operação.

O assunto é vasto tornando sua delimitação necessária. Para 0 presente estudos a simulação é abordada como ferramenta capaz de auxiliar o profissional de logística na tomada de decisão e contribuir significativamente para qualidade do serviço na empresa.

Segundo Prado (1999), existe duas etapas para o estudo de simulação de sistema. $\mathrm{Na}$ primeira o analista deve construir um modelo, fornece alguns dados e obter outros que sejam idênticos ao sistema que está sendo estudado. A segunda etapa consiste na mudança do modelo, para que com base nos resultados obtidos, realizem-se análises, gerando recomendações e conclusões.

Há na empresa pesquisada um procura maior que demanda afetando diretamente o serviço oferecido pela Pet Shop desta forma sua taxa de atendimento é de $81 \%$ em média são dispensados 4 clientes diariamente em media. Com a melhoria proposta na forma de agendamento de cliente, padronização dos processos e fixação de tempos de serviço. A taxa de atendimento passou de $81 \%$ para $94,5 \%$ obtendo um aumento de $13,5 \%$ e os clientes não atendidos passa de 4 para apenas 1 ao dia.

\section{REFERENCIAL TEÓRICO}

Para compreender a simulação será preciso abordar o uso das filas. A fila é um acontecimento do cotidiano todos utilizam a fila em nosso dia a dia seja: em um caixa eletrônico para sacar ou depositar dinheiro; na casa lotérica; em um parquinho aguardando a vez de usar um brinquedo; em um ponto de ônibus; e assim por diante.

Ainda segundo Andrade (2004) é necessário alguns passos para a realização da simulação: Coletar dados e a formulação de uma problemática; A identificação as variáveis as restrições do sistema; Construção do modelo e; Validação do modelo.

Segundo Arenales (2007), a teoria das filas consiste em um método analítico de processos ou sistemas que por meio de fórmulas matemáticas se estuda as relações entre as demandas e os atrasos sofridos pela entidade (usuário) no sistema.

A padronização dos processos procura obter resultados previsíveis, baseado em processos repetitivos, proporcionando e mantendo assim uma predominância das tecnologias nas organizações (MELLO, SILVA, TORRIONI E SOUZA, 2008).

De acordo com Campos (2004), a empresa nada mais é do que um processo onde dentro dela ocorrem vários outros processos, sendo que estes mesmos processos não precisam ser somente de um tipo como manufatura, mas podem ser diversos, como de serviços também.

Krajewski; Ritzman; Malhotra (2009), afirma que o desempenho de um sistema de filas é medido por cinco variáveis: comprimento da fila numero de clientes no sistema, tempo de espera na fila, tempo total no sistema e a utilização da instalação do serviço.

\section{METODOLOGIA}

A metodologia corresponde a um conjunto de procedimentos a ser utilizado na obtenção do conhecimento. É a aplicação do método, por meio de processos e técnicas, que garante a legitimidade científica do saber obtido. (BARROS e LEHFELD, 2010 p. 2).

Os dados apresentados foram coletados e apurados de forma quantitativa através de questionário aplicada em loco no período de 12/2017. 
Foram realizadas visitas ao estabelecimento com o objetivo de analisar o funcionamento do processo estudado e coletar dados para alimentar o modelo computacional. Os dados coletados representa três meses de trabalho, seis dias por semana e oito horas de trabalho considerando uma hora de almoço.

O modelo que representa o sistema é o $M / M / 1$, pois nesta situação a fila formada pode acomodar um número limitado (finito) de entidades dentro do sistema. É um sistema de fácil compreensão, o cliente chega e é atendido de acordo com a ordem se chegada. Para Brighenti (2006), o processo de simulação segue o método científico, ou seja, formula as hipóteses, prepara o experimento, testa as hipóteses através do experimento e valida às hipóteses através dos resultados obtidos.

Os dados foram coletados através de entrevistas à empresa como já citado. Após a coleta, os dados foram lançados na ferramenta Excel e tratadas, após esse tratamento, os dados foram lançados no Input Analyser do software arena para organização, tratamento, validação e geração de informações. Feito isso, obteve-se um relatório com os resultados, que serão analisados. Os demais processos são constantes devido ao procedimento interno no estabelecimento.

\section{ESTUDO DE CASO}

\subsection{PET-SHOP}

A pesquisa foi realizada in-loco por meio de coleta de dados e entrevista com a proprietária da Pet Shop. A pesquisa assume a forma de um estudo de caso da Pet Shop localizada no bairro do conjunto Habitacional Águia de Haia em São Paulo SP, no setor de banho e tosa possui dois profissionais para este procedimento.

\subsection{PESQUISA NOS PROCESSOS, UTILIZANDO O ARENA}

A primeira parte desta pesquisa e artigo irá examinar o comportamento da operação da loja e o tamanho da fila. A segunda parte irá tratar os dados apurados deste comportamento e em seguida propor melhorias na operação.

O Software Arena disponibiliza relatórios para a realização de análises do sistema. Os relatórios mostram uma visão do sistema, como médias de valores, as replicações que foram executadas, etc.

Tabela 1 - Tempos de Chegada em Hora

\begin{tabular}{|c|c|c|c|c|c|}
\hline 0,37 & $-0,12$ & 0,64 & 1,16 & 1,12 & 1,39 \\
\hline$-0,57$ & 0,40 & 1,07 & $-0,02$ & 0,18 & $-0,32$ \\
\hline$-0,40$ & 0,03 & 0,13 & $-0,54$ & 0,24 & 0,32 \\
\hline 0,59 & 0,34 & 0,36 & 0,34 & 1,19 & 0,48 \\
\hline 0,43 & 0,26 & 1,51 & 0,95 & 1,71 & 0,19 \\
\hline 0,46 & 0,39 & 1,05 & 0,36 & 1,54 & $-0,06$ \\
\hline 0,59 & 0,46 & 1,15 & 0,36 & 1,76 & $-0,22$ \\
\hline 0,72 & 0,53 & 1,25 & 0,35 & 1,98 & $-0,38$ \\
\hline 0,85 & 0,60 & 1,35 & 0,35 & 2,20 & $-0,54$ \\
\hline 0,97 & 0,67 & 1,45 & 0,34 & 2,42 & $-0,70$ \\
\hline 1,10 & 0,74 & 1,56 & 0,34 & $-0,86$ & $-1,02$ \\
\hline 1,23 & 0,81 & 1,66 & 0,33 & 1,36 & 0,88 \\
\hline 1,76 & 0,32 & & & & \\
\hline
\end{tabular}

Fonte: Os autores (2018). 
O Input Analyser tem o propósito de auxiliar nas tarefas de tratamento de dados e a identificação da distribuição de probabilidades por meio de testes de aderências. O resultado é uma expressão que pode ser usada no Arena. Conforme pode ser visto na Tabela 2.

Tabela 2 - Distribuições e Expressões dos Processo

\begin{tabular}{|l|c|c|}
\multicolumn{1}{|c|}{ Processo } & Distribuição & Expressão \\
\hline Chegada dos Animais & LOGN & $-0.5+$ LOGN $(3.43,4.35)$ \\
\hline Limpeza de Ouvido & WEIBULL & WEIB $(4.62,1.45)$ \\
\hline Corte de Unhas & LOGN & $\operatorname{LOGN}(4,3.6)$ \\
\hline Primeira Tosa & WEIBULL & $1+$ WEIB $(7.92,1.15)$ \\
\hline Pré Banho & LOGN & $6+\operatorname{LOGN}(18.9,22.3)$ \\
\hline Enxague Pelo Curto & BETA & $9+112^{*} \mathrm{BETA}(0.45,1.17)$ \\
\hline Enxague Pelo Longo & LOGN & $10+\operatorname{LOGN}(15.1,44.8)$ \\
\hline Secagem & EXPONENTIAL & $10+\operatorname{EXPO}(28.6)$ \\
\hline
\end{tabular}

Fonte: Os autores (2018).

Para a realização deste estudo foram desconsiderados processos mais complexos de banho e tosa. Na coleta de dados foram obtidos o tempo de chegada, o tempo de atendimento em cada processo.
A Tabela 3 apresenta os tempos padronizados dos processos realizado na empresa após o estudo. Os tempos a cima foram os ideais para o melhor atendimento dos clientes.

Tabela 3 - Tempos Padronizados

\begin{tabular}{|l|c|}
\hline \multicolumn{1}{|c|}{ Processo } & Expressão / Constant \\
\hline Aplicação de produto para pelo escuro curto & 5 min. \\
\hline Aplicação de produto para pelo claro curto & 5 min. \\
\hline Aplicação de produto para pelo escuro longo & 5 min. \\
\hline Aplicação de produto para pelo claro longo & $5 \mathrm{~min}$. \\
\hline Tempo de ação do produto para pelo escuro curto & $8 \mathrm{~min}$. \\
\hline Tempo de ação do produto para pelo claro curto & $8 \mathrm{~min}$. \\
\hline Tempo de ação do produto para pelo escuro longo & $10 \mathrm{~min}$. \\
\hline Tempo de ação do produto para pelo claro longo & $10 \mathrm{~min}$. \\
\hline
\end{tabular}

Fone: Os autores (2018)

Na Figura 1, podemos visualizar o modelo do arena construído e sugerido após a pesquisa, no qual foram padronizado os tempos de atendimento de cada processo realizado durante a operação. 
Figura 1 - Layout do Cenário Sugerido

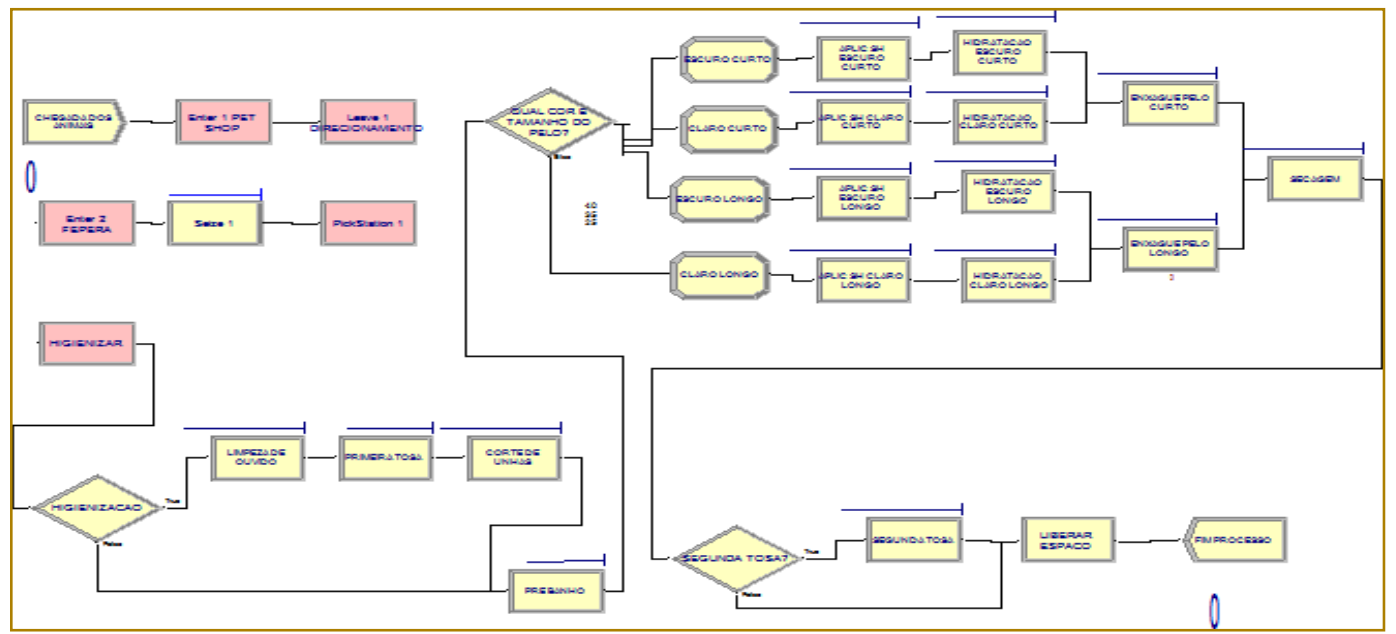

Fonte: Os autores (2018).

Nos Quadros 1 e 2, podemos verificar um dos relatórios extraído do software arena, ele aponta o comportamento do tempo de espera na fila. A Figura 2 é referente à situação inicial da pesquisa com tempo médio de espera 176,64 minutos.

\section{Quadro 1 - Tempo de Espera $1^{\circ}$ Cenário}

\begin{tabular}{|c|c|c|c|c|c|c|}
\hline Queue & & & & & & \\
\hline \multicolumn{7}{|l|}{ Time } \\
\hline Waiting Time & Average & Half Width & $\begin{array}{c}\text { Minimum } \\
\text { Average }\end{array}$ & $\begin{array}{c}\text { Maximum } \\
\text { Average }\end{array}$ & $\begin{array}{c}\text { Minimum } \\
\text { Value }\end{array}$ & $\begin{array}{c}\text { Maximt } \\
\text { Val }\end{array}$ \\
\hline AGENDAMENTO.Queue & 176.64 & 31,80 & 18.2230 & 558.30 & 0.00 & 993.: \\
\hline $\begin{array}{l}\text { APLIC SH CLARO } \\
\text { CURTO.Queue }\end{array}$ & 2.1720 & 0,80 & 0.00 & 10.5117 & 0.00 & $59.78:$ \\
\hline $\begin{array}{l}\text { APLIC SH ESCURO } \\
\text { CURTO.Queue }\end{array}$ & 2.3633 & 0,75 & 0.00 & 10.9110 & 0.00 & 58.24: \\
\hline $\begin{array}{l}\text { APLIC SH ESCURO } \\
\text { LONGO.Queue }\end{array}$ & 2.0059 & 1,04 & 0.00 & 13.3970 & 0.00 & 57.881 \\
\hline CORTE DE UNHAS. Queue & 1.0700 & 0,71 & 0.00 & 12.4130 & 0.00 & 59.74 \\
\hline $\begin{array}{l}\text { ENXAGUE PELO } \\
\text { CURTO.Queue }\end{array}$ & 2.0672 & 0,59 & 0.00 & 10.8626 & 0.00 & $59.69 \mathrm{i}$ \\
\hline $\begin{array}{l}\text { ENXAGUE PELO } \\
\text { LONGO.Queue }\end{array}$ & 1.4230 & 0,95 & 0.00 & 14.5986 & 0.00 & 58.39 \\
\hline HIDRATACAO CLARO & 2.2365 & 1.01 & 0.00 & 15.8811 & 0.00 & 59.76: \\
\hline
\end{tabular}

Fonte: Os autores (2018).

O Quadro 2 apresenta o tempo médio de espera 28,1197minutos sendo este o modelo proposto pela pesquisa. Segundo Prado (2009), existe duas etapas para o estudo de simulação de sistema. Na primeira o analista deve construir um modelo, fornece alguns dados e obter outros que sejam idênticos ao sistema que está sendo estudado. 
Quadro 2 - Tempo de Espera $2^{\circ}$ cenário

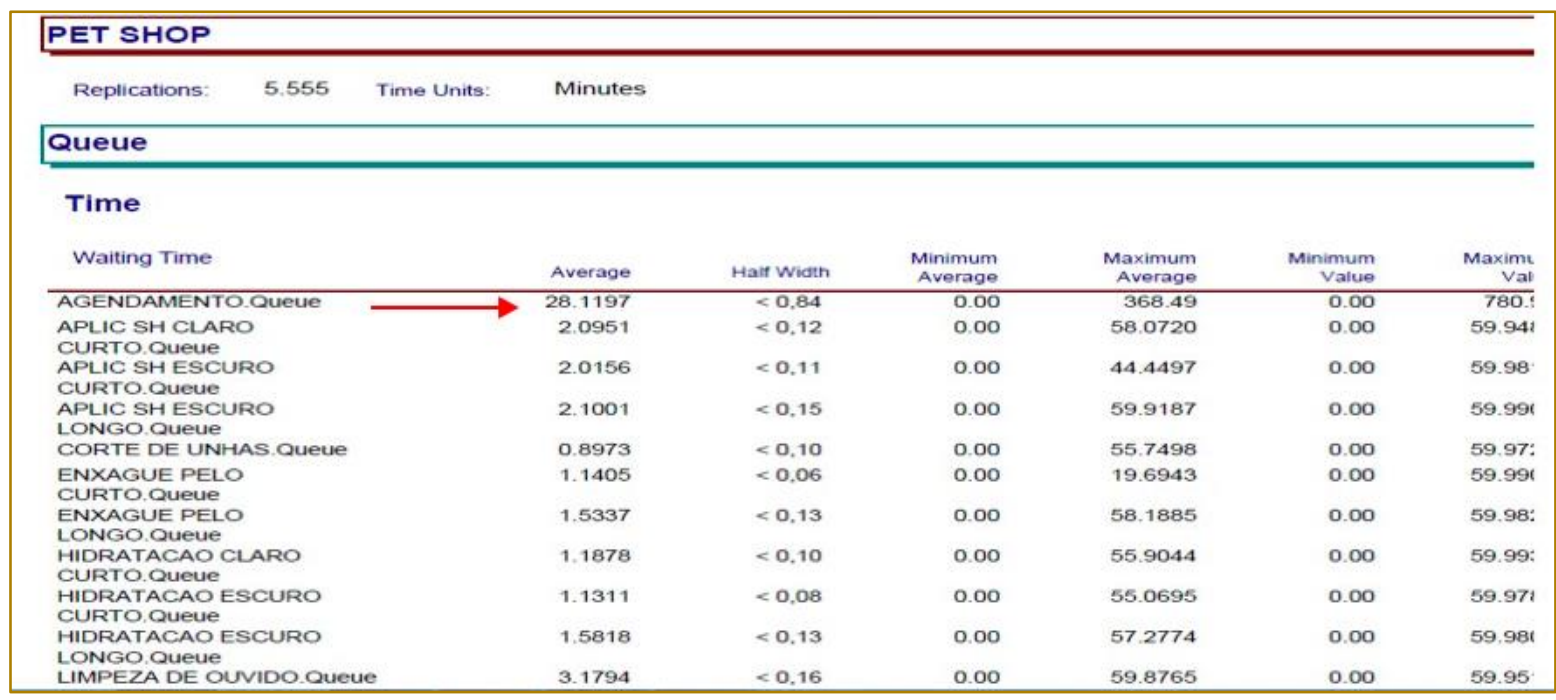

Fonte: Os autores (2018).

Os relatórios que informam o nível de utilização dos recursos do sistema são apresentados nas Quadro 3 e 4, sendo respectivamente 0 modelo inicial dos processos e o modelo final. Podemos observar que a utilização dos recursos no modelo inicial era de $43 \%$ do espaço e $39 \%$ do operador.

Quadro 3 - Utilização dos Recursos $1^{\circ}$ cenário

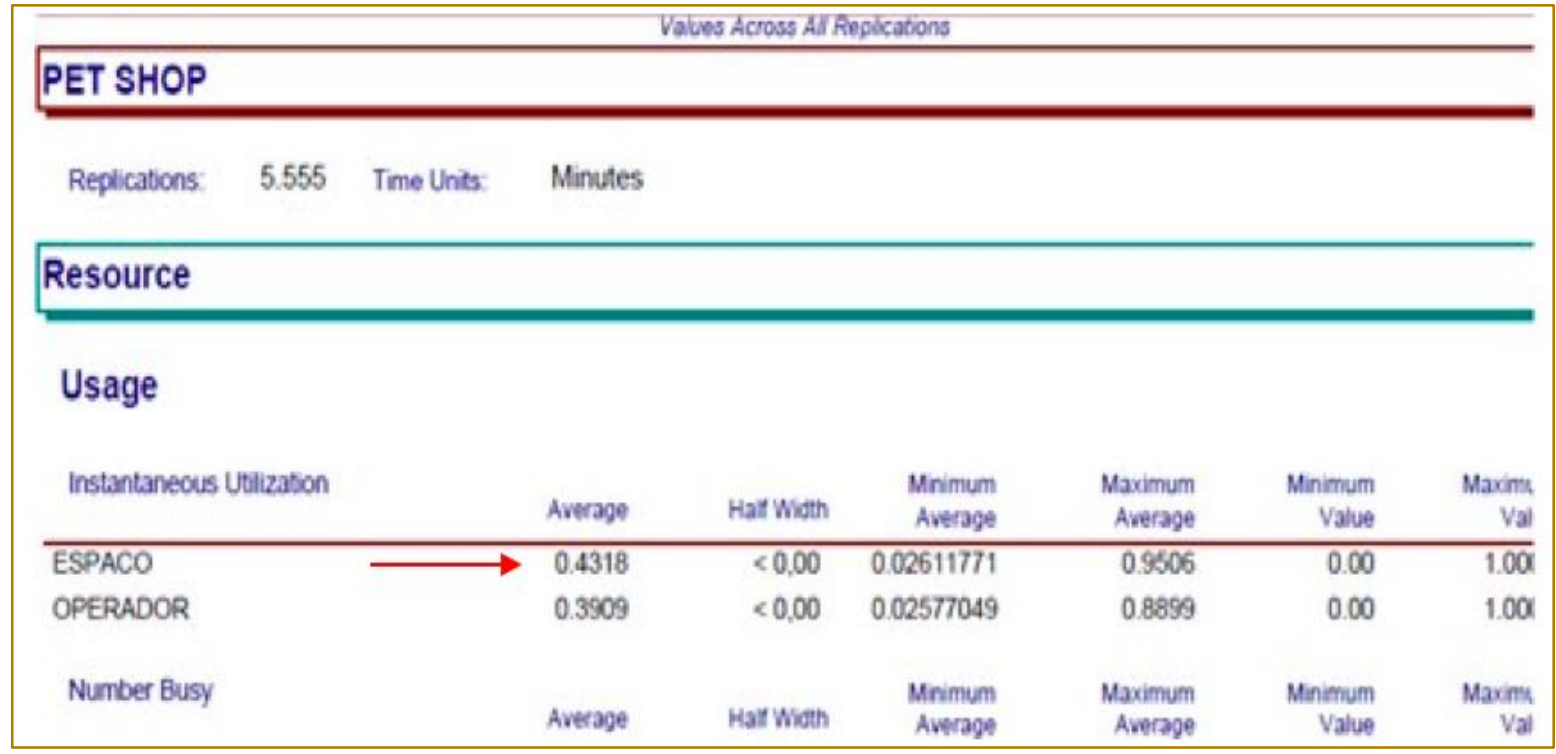

Fonte: Os autores (2018).

O relatório exposto na Quadro 4 mostra o nível de utilização dos recursos do modelo proposto pela pesquisa onde o espaço tem taxa de utilização de $89 \%$ e do operador de $79 \%$. 
Quadro 4 - Utilização dos recursos $2^{\circ}$ cenário proposta

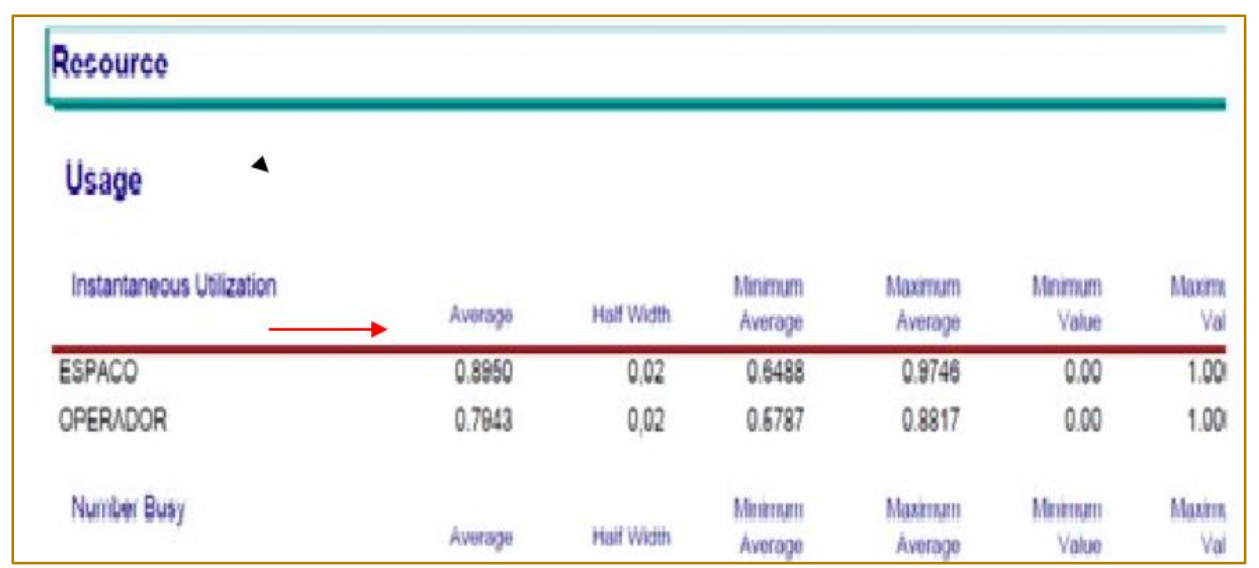

Fonte: Os autores (2018).

$\mathrm{Na}$ Tabela 4 são apresentados problemas encontrados na operação e no serviço da empresa estudada e, propostas de melhorias sugeridas pelo estudo realizado através da presente pesquisa.

Tabela 4 - Tabela de Identificação das causas e propostas de melhorias

\begin{tabular}{c|l|l|l|}
\multicolumn{5}{c}{$\begin{array}{c}\text { Causa } \\
\text { Situação }\end{array}$} & $\begin{array}{c}\text { Primária } \\
\text { Problema }\end{array}$ \\
$\begin{array}{c}\text { Taxa } \\
\text { elevada de } \\
\text { cliente. }\end{array}$ & $\begin{array}{l}\text { A agenda } \\
\text { sempre aberta } \\
\text { para novos } \\
\text { encaixes. }\end{array}$ & $\begin{array}{l}\text { Procura maior } \\
\text { que a } \\
\text { demanda. }\end{array}$ & $\begin{array}{l}\text { Padronização do atendimento e dos processos } \\
\text { operacionais, com tempos fixos e pré-determinados } \\
\text { para cada tipo de cliente (animal). Estabelecer quantos } \\
\text { encaixes podem ser realizados diariamente. }\end{array}$ \\
\hline $\begin{array}{c}\text { Desistênci } \\
\text { a do } \\
\text { cliente }\end{array}$ & $\begin{array}{l}\text { Demora no } \\
\text { atendimento }\end{array}$ & $\begin{array}{l}\text { Perda de } \\
\text { cliente }\end{array}$ & $\begin{array}{l}\text { Oferecer um agendamento que seja possível o } \\
\text { atendimento, orientar os clientes com agenda que } \\
\text { informe antecipado sua desistência. Torna a área de } \\
\text { espera mais agradável ao animal e seu dono. }\end{array}$ \\
\hline $\begin{array}{c}\text { Desperdíci } \\
\text { o do } \\
\text { tempo }\end{array}$ & $\begin{array}{l}\text { Falta de } \\
\text { padronização } \\
\text { dos processos }\end{array}$ & $\begin{array}{l}\text { Serviço sem } \\
\text { padrão de } \\
\text { qualidade }\end{array}$ & $\begin{array}{l}\text { Fixar tempos de acordo com o tamanho de cada animal, } \\
\text { tamanho e cor do pelo temperamento, escala de } \\
\text { frequência. }\end{array}$ \\
\hline
\end{tabular}

Fonte: Os autores (2018).

Em geral não se pode admitir mais de um usuário sendo atendido pelo mesmo servidor no mesmo instante, caso contrário, esse tipo de atendimento acontece somente em um serviço em lote. Exemplo: um elevador transporta várias pessoas ao mesmo tempo. (ARENALES et al., 2007, p. 437).

Após análise dos dados obtidos com a pesquisa de campo e uso do software Arena os resultados apontaram o tempo de agendamento como o gargalo operacional da Pet Shop, com as médias obtidas com a pesquisa foi propostos um remanejo nos horários de agendamento que serão estabelecidos conforme o tamanho do animal e a cor do pelo.

Para que sejam atendidas todas as entidades que entram no processo será adotada uma taxa de agendamento que deve variar entre uma hora e uma hora e meia com isso as entidades serão atendidas e a empresa terá uma melhor qualidade no serviço oferecido a seus clientes.

A Tabela 5 expõe os dados dos relatórios extraídos pelo Arena, de acordo com os dados pode-se ter uma visão do cenário estudado e realizar um paralelo comparativo entre o primeiro e o segundo cenário, quanto à taxas de entidades, taxas de ocupação, o 
tamanho da fila, o tempo médio de espera em cada fila, entre outras. De posse destas informações o gestor poderá tomar decisões bem mais assertivas.

Tabela 5 - Tabela de dados do relatório arena

\begin{tabular}{|c|c|c|c|c|c|}
\hline \multicolumn{6}{|c|}{ Dados do Relatório } \\
\hline & Entrada & Saída & $\begin{array}{c}\text { Em } \\
\text { processo }\end{array}$ & $\begin{array}{c}\text { Taxa de } \\
\text { atendimento }\end{array}$ & $\begin{array}{l}\text { Taxa de não } \\
\text { atendimento }\end{array}$ \\
\hline $1^{\circ}$ Cenário & 21 & 17 & 4 & $81 \%$ & $19 \%$ \\
\hline $2^{\circ}$ Cenário & 18 & 17 & 1 & $94,50 \%$ & $5,50 \%$ \\
\hline \multicolumn{6}{|c|}{ Taxa de ocupação $1^{\circ}$ cenário } \\
\hline & Média & $\begin{array}{l}\text { Intervalo de } \\
\text { confiança }\end{array}$ & Mínimo & Máximo & \\
\hline Espaço & $43 \%$ & $<0.00$ & 0.026 & 0.95 & \\
\hline \multirow[t]{3}{*}{ Operadores } & $39 \%$ & $<0.00$ & 0.026 & 0.89 & \\
\hline & \multicolumn{5}{|c|}{ Taxa de ocupação $2^{\circ}$ cenário } \\
\hline & Média & $\begin{array}{l}\text { Intervalo de } \\
\text { confiança }\end{array}$ & Mínimo & Máximo & \\
\hline Espaço & $89 \%$ & $0.02 \%$ & $0.64 \%$ & $97 \%$ & \\
\hline Operadores & $79 \%$ & $0,02 \%$ & $58 \%$ & $88 \%$ & \\
\hline \multicolumn{6}{|c|}{ Tamanho da Fila $1^{\circ}$ Cenário } \\
\hline & № de entidades & $\begin{array}{c}\text { Intervalo de } \\
\text { confiança }\end{array}$ & Mínimo & Máximo & \\
\hline & 2.72 & 0.54 & 0.2876 & 83.563 & \\
\hline \multicolumn{6}{|c|}{ Tamanho da Fila $2^{\circ}$ Cenário } \\
\hline & № de entidades & $\begin{array}{c}\text { Intervalo de } \\
\text { confiança }\end{array}$ & Mínimo & Máximo & \\
\hline & 2 & $<0.01$ & 0.00 & 43.35 & \\
\hline \multicolumn{6}{|c|}{ Tempo médio na Fila $1^{\circ}$ Cenário } \\
\hline & Tempo de Espera & \multicolumn{2}{|c|}{ Intervalo de confiança } & Mínimo & Máximo \\
\hline & 176,64 minutos & & 31.80 & 18.22 & 558.3 \\
\hline \multicolumn{6}{|c|}{ Tempo médio na Fila $2^{\circ}$ Cenário } \\
\hline & Tempo de Espera & \multicolumn{2}{|c|}{ Intervalo de confiança } & Mínimo & Máximo \\
\hline & 28,1197 & $<0.84$ & & 0.00 & 368.49 \\
\hline
\end{tabular}

Fone: Os autores (2018)

No primeiro cenário foram realizadas 5 replicações, e com isso, o resultado das 
aplicações no relatório, foi possível definir quantas replicações é necessário para alcançar o intervalo de confiança necessário. Na primeira análise o half widf foi de 13,34. Aplicando esse valor na formula, o número de replicações necessário para este estudo de caso foi de aproximadamente de 5555 replicações.

Após as 5555 replicações, foi observado que no primeiro cenário 21 animais entraram no sistema e 17 saíram, isso indica que $81 \%$ dos animais passaram no sistema em um turno de 7 horas de trabalho, os demais permaneceram aguardando para serem atendidos 4 animais, isso representa 19\% de não atendimento.

O tempo médio da fila foi 176. 64 minutos no sistema do modelo inicial apontando o agendamento como sendo o gargalho, ou seja, o Pet Shop está agendando sem ter a certeza que todos os animais serão atendidos no mesmo dia.

As taxas de ocupação dos operadores não foram consideradas satisfatórios neste primeiro cenário, os atendentes apresentaram respectivamente as taxas de $39 \%$ e o espaço $43 \%$. Já no segundo modelo apresentado nesta pesquisa às taxas de ocupação apresentadas são $89 \%$ para o espaço e de $79 \%$ para o operador.

Os resultados obtidos apontam que a empresa dispõe de ótima frequência de usuários, no entanto não tem um controle efetivo de sua demanda.

A questão da falta de padronização nos tempos ao longo do processo fica evidenciada se compararmos com os resultados obtidos nesta pesquisa que podem ser vistos na figura 10, na qual os dados mostram que a taxa de atendimento era de $81 \%$ e de não atendimento era de 19\%\%, 4 clientes serão dispensados diariamente no modelo inicial.

Após a padronização dos tempos dos processos, e o maior controle no agendamento podemos obter uma melhora significativa nas médias de atendimento conforme sãoapresentados na figura 10 que passam a ser de $94,5 \%$ para atendimento e de $5,50 \%$ para não atendimento, neste novo cenário apenas 1 cliente deixa de ser atendido.

\section{CONSIDERAÇÕES FINAIS}

Após a aplicação da simulação no Pet Shop e análise dos resultados obtidos, pode-se dizer que o objetivo principal do trabalho foi alcançado, foi possível demonstrar bem próximo da realidade, funcionamento deste sistema. O uso do Arena possibilitou visualização, compreensão e o comportamento das filas.

O presente trabalho comprovou a importância do uso de ferramentas como Arena como fonte de análise sem a necessidade de programar-la na realidade reduzido custos e risco de prejuízo com projetos. Vimos também que o simulador não se restringe somente em indústrias e seus processos produtivos.

Para que haja um bom atendimento e o serviço oferecido seja aplicado com qualidade, se faz necessário que os planos operacionais estejam em conjunto com ações administrativas busquem atuar de forma articulada entre o planejamento e a ação, desta forma o sistema operacional implantado responderá as expectativa desejadas, ou seja, a atuação de forma eficaz entre o planejamento da agenda e as atividades operacionais dentro da empresa seguindo uma padronização de horário refletiram na melhoria continua.

A necessidade de conscientização da integração entre a agenda e os processos, a padronização dos tempos aplicados em cada estágio dentro da Pet Shop são apontados pela pesquisa como a atitude ideal para melhoria nas ações de melhorias continuas.

Os problemas encontrados na Pet Shop auxiliam no processo de definição de melhorias e programas de incentivo das mesmas.

E por fim, considerando-se dentro deste assunto de Simulações e Processos, como uma das principais contribuições desta pesquisa e trabalho, um maior aprofundamento sobre o tema pesquisado, onde outros pesquisadores possam desenvolver estudos em modelos de simulação, layout e processos e também ficando par sugestão de oportunidades para futuras pesquisas dentro do tema. 


\section{REFERENCIAS}

[1]. ANDRADE, E. L. Introdução à Pesquisa Operacional: Métodos e Modelos para análise de Decisões. 3.ed. Rio de Janeiro: LTC, 2004. 192p.

[2]. ARENALES, M. Pesquisa operacional: para cursos de engenharia. Rio de Janeiro: Elsevier, 2007.

[3]. BARROS, A. J. S. e LEHFELD, N. A. S. Fundamentos de Metodologia: Um Guia para a Iniciação Científica. 2 Ed. São Paulo: Makron Books, 2000

[4]. BRIGHENTI, J. R. N. Simulação e otimização de uma linha de manufatura em fase de projeto. 2006. 113 f. Dissertação (Mestrado em Engenharia de Produção) - Universidade Federal de Engenharia de Itajubá, Itajubá, 2006.

[5]. CAMPOS, Vicente Falconi. TQC: controle da qualidade total (no estilo japonês). 8.ed. Minas Gerais: Falconi. 2004.

[6]. KRAJEWSKI, LEE,LARRY; RITZMAN, LARRY; MALHOTRA, Manoj. Administração de
Produção e Operações. 8. ed. São Paulo: Pearson, 2009.

MELLO, C. H. P.; SILVA, C. E. S.; TURRIONI, J. B.; SOUZA, L. G. M. ISSO 9001:2008 - Sistemas de Gestão da Qualidade para Operações de Produção e Serviços. Editora Atlas, 2008.

[8]. PEGDEN, Claude Dennis, SHANNON, Robert. E., SADOWSKI, Randall P. Introduction to Simulation using SIMAN. 2ed. New York: McGraw Hill, 1995.

[9]. PRADO, D. Teoria das filas e da simulação. Belo Horizonte: Editora de Desenvolvimento Gerencial, 1999. (Série Pesquisa Operacional, Vol. 2). 124 p.

[10]. SANTANA, Peri da Silva e SANTANA, José Carlos Curvelo. Gestão de Operações e Logística na Estratégia Empresarial. REGS - Educação, Gestão e Sociedade: Revista da Faculdade Eça de Queiros, ISSN 2179-9636, Ano 2, número 7 , setembro de 2012. 


\section{Gapítulo 10}

\section{PREVISÃO DE DEMANDA ENTRE DIFERENTES MODELOS APLICADOS A MEDICAMENTOS DO PROGRAMA FARMÁCIA POPULAR}

\section{Paulo André de Oliveira \\ Valquíria Ribeiro de Souza \\ Sérgio Augusto Rodrigues \\ Ricardo Ghantous Cervi}

Resumo: A maneira como os materiais são administrados em uma organização caracteriza a capacidade dessas em alcançar seus objetivos. Quando se trata de organizações relacionadas à saúde pública, quanto maior for a capacidade de gerir os materiais de forma correta, melhor será o desempenho para o fornecimento de bons serviços e atendimentos aos seus clientes, ou seja, pacientes. Este trabalho tem como objetivo avaliar três modelos de previsão de demanda de medicamentos distribuídos pelo programa Farmácia Popular Brasil em uma drogaria e identificar qual é o melhor modelo a ser utilizado, levando em consideração os custos e a disponibilidade do medicamento em um determinado período de tempo. O estudo foi realizado empregando a metodologia de comparação por meio do Desvio Médio Absoluto entre os modelos de previsão propostos, como a média móvel simples, média móvel ponderada e suavização exponencial com cinco tipos de ponderações (alfas), na coleta de dados foram empregadas as técnicas de pesquisas sobre as demandas dos produtos. Concluiu-se que o melhor modelo de previsão a ser utilizado na empresa é o de suavização exponencial com alfa 0,5, resultando em um melhor desempenho na economia dos custos de compras e na diminuição do estoque, gastos esses que geram despesas extras a empresa. Os produtos foram comprados a mais do que utilizados, ou comprados a menos do que foram vendidos com diferença de no mínimo $20,59 \%$ até $414 \%$ do consumo real. O produto que maior se distorceu da realidade foi o Glifage, que teve um custo de erro de $R \$ 26.863,69$, produto comprado a mais do que comercializado e $\mathrm{R} \$ 2.467,43$ entre os produtos que não foram comprados por falta de previsão.

Palavras-chave: Demanda. Estoque. Farmácia Popular 


\section{INTRODUÇÃO}

A maneira como os materiais são administrados em uma organização caracteriza a capacidade dessas em alcançar seus objetivos. Quando se trata de organizações relacionadas à saúde pública, quanto maior for a capacidade de gerir os materiais de forma correta, melhor será o desempenho para o fornecimento de bons serviços e atendimentos aos seus clientes, ou seja, pacientes. Por se tratarem de materiais de caráter urgente, como os medicamentos, é necessário que se evite ao máximo o excesso e a falta desses materiais, duas condições que afetam diretamente o desempenho operacional e financeiro da organização.

A falta de produtos pode provocar prejuízos à organização, além de trazer custos adicionais aos setores de compras, por se tratarem de pedidos emergenciais as quais são mais caras que as compras normais, além de ficar com sua imagem degredada no mercado. Já o excesso de materiais é tão prejudicial quanto a falta, visto que produtos estocados consomem recursos aos quais poderiam ser aplicados em outros setores, além de ocupar espaço de produtos que possuem alto índice de rotatividade precisando em vários casos de depósitos maiores para sua estocagem, além do risco de perder mercadorias por perecibilidade, gerando custos irreversíveis a organização.

Para que esses fatos não ocorram constantemente, utiliza-se formas de previsão de demandas as quais suprem os compradores de informações para tomarem suas decisões de formas coerentes, sem que haja a falta ou excesso de suprimentos. Um bom planejamento da demanda é a utilização dos seus dados juntamente com a aplicação de modelos corretos. Os modelos mais utilizados para a previsão de demanda são os modelos qualitativos e modelos quantitativos os quais auxiliam a achar o melhor modelo a ser utilizado dentro da organização, visando à economia e ao planejamento correto de compra de materiais sem que haja falta ou excesso dos mesmos.

Este estudo tem como objetivo avaliar três modelos de previsão de demanda de medicamentos distribuídos pelo programa Farmácia Popular Brasil em uma drogaria e identificar qual é o melhor modelo a ser utilizado, levando em consideração os custos e a disponibilidade do medicamento em um determinado período de tempo.

\section{EMBASAMENTO TEÓRICO OU REVISÃO DA LITERATURA}

Um dos grandes desafios de uma empresa é saber balancear o estoque em termos de produção (ou através de produtos já fabricados) com a demanda a ser atendida. Os estoques trazem custos, consome capital, ocupam espaço e necessitam de pessoas para o gerenciamento tanto na entrada como na saída dos produtos, interferindo assim diretamente nos resultados das empresas.

Para se ter um bom estoque é preciso definir a hora certa de compra, a quantidade certa, melhores preços, qualidade do produto e de serviços, além de dados que ajudarão a reconhecer sua demanda. Todos esses fatores ajudam na maneira correta de formar 0 melhor estoque.

Segundo Bertaglia (2009, p. 331), "O gerenciamento de estoque é um ramo da administração de empresas que está relacionado com o planejamento e o controle de estoques de materiais ou produtos que serão utilizados na produção ou na comercialização de bens ou serviços."

Para Barbosa e Chaves (2012) a demanda independente "é a demanda que não pode ser derivada através de cálculo a partir dos itens da estrutura de produto, isto ocorre porque os itens de demanda independente são geralmente os itens "pais", ou seja, são os itens mais altos da estrutura de produto e por este motivo esta demanda deve ser prevista."

Esse tipo de demanda é suprido sem ter qualquer visibilidade concreta e antecipada do pedido dos clientes. Os itens demandados são peças e produtos acabados, que serão fornecidos pelo comércio ou distribuidores em geral, esses mesmos possuem uma previsão sujeita a erros e incertezas, pois não tem como programar a quantidade nem a variedade dos produtos fornecidos.

Segundo Bertaglia (2009, p. 344), a demanda dependente é "determinada pelas decisões de produção e está vinculada a uma demanda independente".

Conforme Barbosa e Chaves (2012), a demanda dependente "é a que pode ser derivada através de cálculo direto a partir da quantidade dos itens em nível mais alto da estrutura de produto, podendo ser computada através do MRP (Material Requirement Planning)." 
Esse tipo de demanda é relativamente previsível, pois depende de outros fatores internos dentro de uma organização, ou seja, os itens da demanda dependente são usados na produção interna de outros itens. A quantidade demandada depende da requisição do cliente, onde a quantidade pedida e o momento em que ela deve estar disponível na produção estão relacionados às previsões de mercado ou encomendas realizadas por clientes.

Cada vez mais as empresas estão preocupadas com $\mathrm{o}$ atendimento $\mathrm{da}$ demanda, seja ela dependente ou independente, pois suas previsões farão com que problemas inesperados não ocorram e que as necessidades dos clientes sejam atendidas.

A previsão de demanda é o modo de tentar determinar o que pode vir a acontecer em certo horizonte de tempo. Essa antecipação é útil para determinar, por exemplo: a necessidade de compra futura de equipamentos e instalações; a demanda por produtos já fabricados por uma empresa; a demanda de produtos que ainda serão lançados" (BARBIERI E MACHLINE, 2006)

Para cada tipo de previsão de demanda é preciso que haja um estudo do melhor modelo para ser utilizado, sempre pensando na maneira mais vantajosa para a empresa, tanto na parte financeira como na administração dos materiais.

Porém como está ligado diretamente com as decisões humanas, como comprar ou não comprar um produto ou a fatores que variam, por exemplo, a renda da família, preços ou mudanças de hábitos, não se pode esperar um resultado preciso dessa previsão.

Dessa forma, segundo Novaes (2007, p. 160), é importante levar em consideração que "as previsões estão sempre sujeitas a erros, sendo que as projeções de longo prazo são usualmente menos precisas do que as de curto prazo, devido a economia, os hábitos do consumidor, os efeitos políticos internos e externos normalmente sofrerem mudanças num ritmo mais lento ao longo do tempo".

Segundo Novaes (2007, p. 163), "os modelos de previsão são classificados de formas diversas, dependendo de aspectos básicos que caracterizam a demanda".

Há vários modelos de previsão os quais podem ser divididos em quantitativos e qualitativos. Segundo Novaes (2007, p. 165), "os modelos qualitativos envolvem processos mentais de julgamento sobre possíveis desdobramentos de ações internas e externas, visando definir prováveis cenários futuros para a tomada de decisões." Já os modelos quantitativos "utilizam dados históricos da própria empresa". (NOVAES, 2006, p.167).

Segundo Barbieri e Machline (2006, p. 90), "a previsão baseada na média móvel aritmética consiste em estimar a demanda futura pela média aritmética da demanda de um número fixo de períodos. A cada novo período, abandona - se a demanda mais antiga e acrescenta - se a nova. Assim o número de períodos para calcular as médias torna - se constante"

É a média mais comum, a média aritmética de $\mathrm{n}$ períodos. É calculada somando-se os valores dos $n$ períodos e dividindo o resultado por $\mathrm{n}$.

Segundo Furtado (2006), "a média móvel é um modelo muito utilizado nas empresas em geral, por ser extremamente simples e necessitar de poucos dados históricos. Ele é indicado para previsões de curto prazo onde os componentes de tendência e sazonalidade são inexistentes ou possam ser desprezadas."

\section{Segundo Corrêa et al (2001):}

Quanto maior o número de períodos passados utilizados no cálculo, maior a suavização das variações aleatórias e menor a sensibilidade do modelo a mudanças de patamar nas vendas, caso venha a ocorrer. Apesar dos problemas, os modelos de média móvel são úteis quando se busca um modelo simples e de baixo custo para prever vendas de muitos itens com histórico de pequenas flutuações e sem indicações de tendências (CORRÊA et al, 2001).

Para Pereira (2006), a média móvel ponderada "é uma variação da média móvel que consiste em ponderar a importância dos períodos da previsão atribuindo-lhes pesos diferentes, conforme se queira mais ou menos ênfase ao período, normalmente com pesos maiores dados mais recentes".

Segundo Barbieri e Machline (2006, p. 92), "se esse modelo pode corrigir a limitação da média móvel aritmética, por um lado, aumenta o número de cálculos e exige que se estabeleça um sistema de ponderação que pode ser operacionalmente inconveniente se o n for grande". 
Conforme Pereira (2006), "a vantagem sobre a média móvel é que os valores mais recentes da demanda, que podem revelar alguma tendência, recebem importância maior. Entretanto, valem as mesmas observações quanto ao valor de n: quanto maior, mais suavizará os efeitos sazonais e mais lentamente responderá a variações".

Segundo Barbieri e Machline (2006, p. 92), "a previsão da demanda pelo modelo conhecido por amortecimento ou suavização exponencial consiste numa média ponderada da demanda dos períodos passados, segundo uma estrutura de ponderação exponencial".

Para Ballou (2006) o modelo de suavização exponencial "é simples, e possui a capacidade de se adaptar às mudanças fundamentais nos dados de previsão. Nela, as observações passadas não recebem peso igual, ou seja, as observações mais recentes são sempre mais bem cotadas do que as mais antigas."

Segundo Barbieri e Machline (2006), o modelo possui vantagens e desvantagens:

Vantagens: Peso diferenciado para cada observação de acordo com a sua idade; maior flexibilidade para ajustar a previsão ao comportamento da demanda; requer a manutenção de poucos dados.

Desvantagem: Reação lenta às mudanças no comportamento da demanda, porém menos que a média móvel aritmética; só fornece a previsão de um único período.

Barbieri e Machline (2006, p. 104) defende que "esse modelo se baseia na seguinte hipótese: a tendência de um período é a diferença entre a média suavizada desse período e a do período anterior".

Segundo Silva (2008), "considerando uma série histórica que apresente um componente de tendência linear de crescimento ou decrescimento, podendo desprezar características como sazonalidade e ciclo, o modelo de Holt pode ser empregado para obter previsões satisfatórias. Neste modelo são definidos dois coeficientes de amortecimento, sendo um específico para ajusta a estimativa de tendência".

Segundo Barbieri e Machline (2006), pode-se destacar sobre os modelos de suavização exponencial:

Vantagens: Todas as vantagens da suavização exponencial; inclusão do fator de tendência; fornece previsão para mais de um período.

Desvantagens: Com dois coeficientes de suavização torna - se mais complexa a gestão da previsão.

Para Barbieri e Machline (2006, p. 110), o modelo de Winter " permite tratar a tendência e a sazonalidade num processo de previsão de demanda".

Segundo Silva (2008), "para séries temporais que, além de uma tendência linear, apresentam a componente de sazonalidade, os modelos de Winters podem ser aplicados apropriadamente". Segundo Barbieri e Machline (2006), o modelo Winter traz:

Vantagens: Todas as vantagens do modelo de Holt; inclusão do fator de sazonalidade; fornece previsão para mais de um período.

Desvantagens: A desvantagem do modelo de Holt fica intensificada com a necessidade de operar três coeficientes de suavização.)

\subsection{FARMÁCIA POPULAR}

"Em 2004, foi instituído pelo governo federal - Programa Farmácia Popular do Brasil (PFPB), o programa foi institucionalizado pela Lei no. 10.858, de 13 de abril de 2004, a qual autoriza a Fundação Oswaldo Cruz FIOCRUZ a disponibilizar medicamentos, através do ressarcimento de seus custos, de forma a assegurar à população o acesso a produtos básicos e essenciais a baixo custo. Tendo sido expandido em 2006 com a Portaria 491 de 09 de março que permitiu a sua operacionalização através da rede privada de farmácias e drogarias". (MOTTA, 2012)

Um dos objetivos do Programa é favorecer as pessoas de baixa renda, viabilizar a realização do tratamento em face ao alto preço dos medicamentos e ainda suportar a população usuária da rede privada de saúde como uma alternativa, já que passaram a ter acesso a medicamentos com preços mais acessíveis. Outro fator importante é que o Programa Farmácia Popular pode contribuir para a diminuição dos gastos gerados pela compra de medicamentos e, também minimizar as despesas do Sistema Único de Saúde com internações que são provocadas pelo abandono do tratamento. (MINISTÉRIO DA SAÚDE, 2015). 
O modelo da Farmácia Popular opera em duas vertentes conforme Motta (2012):

O programa pode ser operacionalizado por meio de dois modelos de gestão. No primeiro modelo a Fundação Osvaldo Cruz é responsável por prover o acesso aos medicamentos através de rede própria de farmácia que pode ser estabelecida por convênios com as três esferas de governo e instituições sobre a supervisão direta do Ministério da Saúde. O segundo modelo de gestão opera na lógica do pagamento podendo o medicamento ser obtido na rede privada conveniada com o programa "Aqui tem Farmácia Popular". Os valores pagos pelo usuário variam em função da versão do medicamento disponível (referência, genérico ou similar) e do preço calculado com base em valor de referência (VR) estabelecido para cada medicamento. Quando o valor de venda for igual ou maior que o VR, o governo paga $90 \%$ do VR e quando menor paga $90 \%$ do valor de venda (MOTTA, 2012).

\section{DESENVOLVIMENTO DA TEMÁTICA}

Para o trabalho, utilizou-se dados de março de 2016 a dezembro de 2017, com 14 produtos do Programa Farmácia Popular disponíveis neste período para uma drogaria em Botucatu/ SP, são eles: Atenolol 25mg 30cpds Sandoz; Bonalen 70mg 4cpds; Captopril 25mg 30cpds Prati ; Glifage XR 500mg c/31; Hidromed 25mg 30cpds; Insulina Insunorm $\mathrm{n}$ frasco $10 \mathrm{ml}$; Insulina Novolin $\mathrm{n}$ frasco $10 \mathrm{ml}$; Losartana potas.50mg $30 \mathrm{cpds}$ Zydus; Metformina 850mg 30cpds Merck;
Propanolol 40mg 30comp União Química; Sinvastamed 20mg 30cpds; Sinvax 40mg 30cpds; Tenoftal $5 \mathrm{mg} / \mathrm{ml}$ oftal. $5 \mathrm{ml}$; Teutoformin 850mg 30cpds.

Para a inicialização do estudo fez-se um levantamento dos produtos que constavam no período citado na drogaria estudada. No primeiro momento para se saber quais produtos teriam o enfoque no estudo, foi construída a curva ABC desses 14 itens. $\mathrm{Na}$ segunda etapa fez - se a avaliação dos produtos com base nos históricos de demanda da drogaria, para que assim pudesse fazer um comparativo entre os modelos de previsão propostos no estudo (média móvel simples, média móvel ponderada e suavização exponencial) e a demanda real dos produtos.

A partir dos resultados previstos por estes modelos foi possível encontrar a taxa do DAM, que de acordo com Freire (2007), o DAM (desvio absoluto médio) estima a dispersão dos valores. Para avaliar o melhor modelo comparou-se o valor do Desvio Absoluto Médio (DAM) como apresentado por Silva e Oliveira (2012).

\section{RESULTADOS E DISCUSSÃO}

A curva ABC, apresentada na Figura 1, permitiu se determinar os produtos que compõem 0 item A que são Glifage, Sinvastamed, Losartana, Sinvax e Bonalen. O somatório destes produtos totaliza $83,1 \%$ dos itens Do Programa Farmácia Popular, sendo objeto do estudo do Desvio Médio Absoluto para previsão de Demanda. 
Figura 1 - Classificação ABC

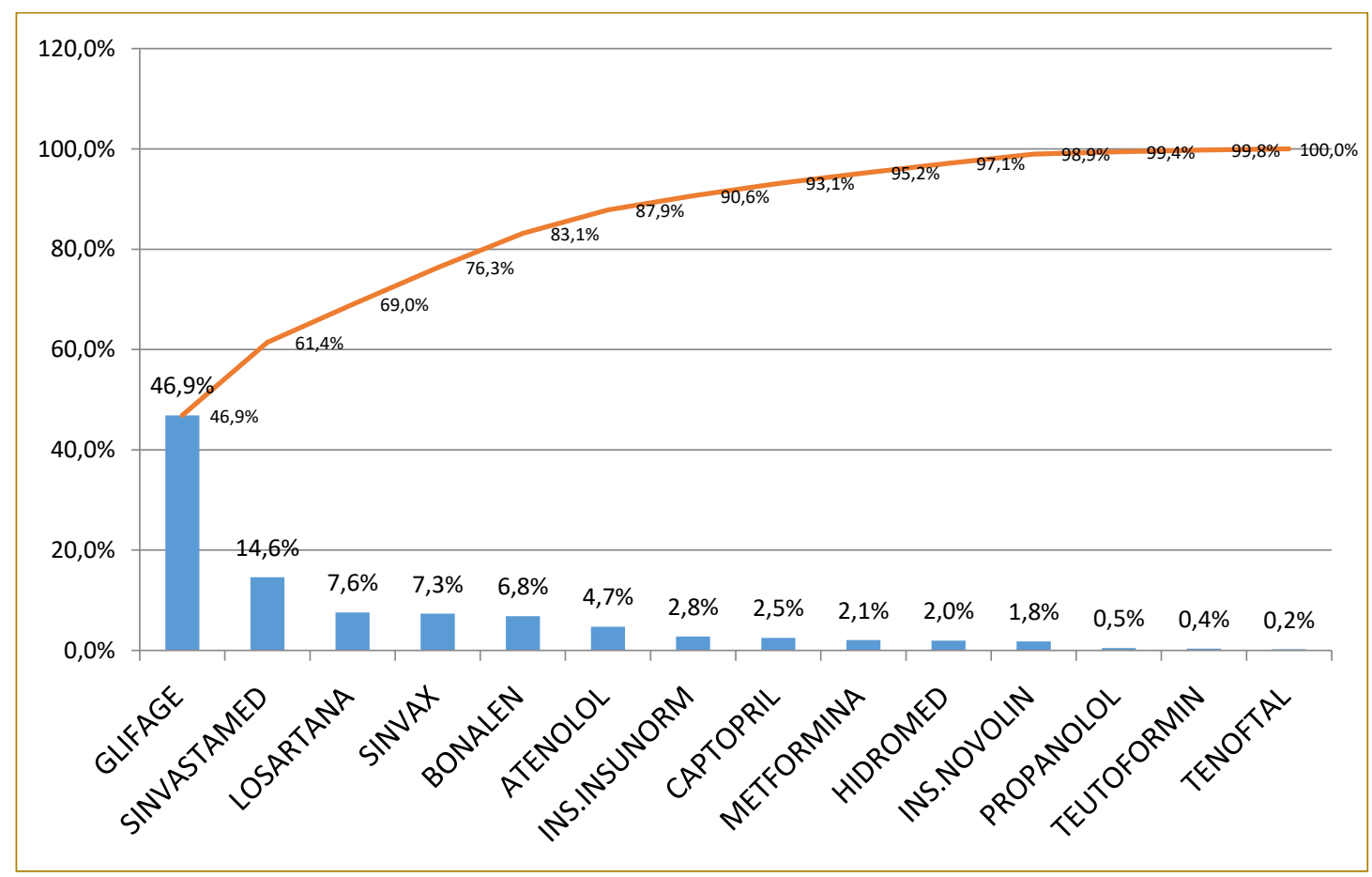

Fonte: Dados da pesquisa

Observou-se que o resultado mais próximo a demanda real em todos os casos foi o modelo de suavização exponencial com alfa de 0,5. Devido as grandes oscilações de demanda de um mês para o outro este modelo apresentou-se $\mathrm{o}$ mais preciso. $\mathrm{O}$ que se observa é que a demanda é aleatória e sem tendências e portanto, necessita de previsões em que o peso da ultima informação de consumo representa cinquenta por cento.

$\mathrm{Na}$ média móvel se ponderou o peso de $33,33 \%$ para cada um dos ultimos itens da demanda apresentando-se o pior resultado para o Glifage (DAM de 24 unidades). Empatou no Sinvastamed e no Bonalen como pior resultado. A média móvel ponderada considera um peso de $10 \%$ para o ultimo resultado, 30\% para o penúltimo e $60 \%$ para o antipenultimo com resultados entre os piores para Glifage, Sinvastamed e Losartana. A suavização exponencial melhorou os resultados foi melhorando de 0,05 até 0,5 , ou seja, quanto maior o peso do ultimo resultado, melhor a previsão.

Comparando-se o o consumo real com a melhor previsão observa-se na tabela 1 que o maior erro foi para o Glifage com 8,68\% a menos do que a demanda real, para todo o período analisado, sendo que o Bonalen apresentou erro inferior a 0,5\%. Pode-se adotar o modelo ajustando-se com uma margem de segurança de mais $10 \%$ para que não ocorra falta de produto. Cabe destacar que a previsão é mensal e se a empresa decidir fazer a compra em períodos maiores como o apresentado na tabela 1 deve-se fazer o somatório do período desejado. 
Tabela 1 - Consumo real e a melhor previsão dos medicamentos

\begin{tabular}{|c|c|c|c|c|}
\hline & $\begin{array}{c}\text { Consumo } \\
\text { (unidades) }\end{array}$ & Melhor Previsão Alfa 0,5 & Erro de Previsão & $\%$ Erro \\
\hline Glifage & 1.112 & $1.015,5$ & -97 & $-8,68 \%$ \\
\hline Sinvastamed & 655 & 633,0 & -22 & $-3,36 \%$ \\
\hline Losartana & 442 & 420,0 & -22 & $-4,98 \%$ \\
\hline Sinvax & 121 & 115 & -6 & $-4,96 \%$ \\
\hline Bonalen & 102 & 102,5 & 1 & $0,49 \%$ \\
\hline
\end{tabular}

Fonte: A pesquisa

A tabela 2 apresenta a comparação entre o consumo real e as compras da empresa para o período estudado onde se demonstra um erro que varia de $-20,59 \%$ para o Bonalen até $414,66 \%$ para o Glifage. O custo de imobilização de estoque foi de $\mathrm{R} \$ 26.863,69$ somente para o medicamento Glifage, o que requer cuidados com desencaixe entre pagamentos e recebimentos da empresa. 0 somatório dos erros de compra dos medicamentos Sinvastamed, Losartana, Sinvax e Bonalen totalizou $\mathrm{R} \$ 2.467,43$.

Tabela 2- Comparação entre consumo real e a compra dos medicamentos (março/2013 a dezembro/2014)

\begin{tabular}{|c|c|c|c|c|c|}
\hline & Consumo Real & Compra & Erro de Compra & \% Erro & Custo do erro \\
\hline Glifage & 1.112 & 5.723 & 4.611 & $414,66 \%$ & $26.863,69$ \\
\hline Sinvastamed & 655 & 435 & -220 & $-33,59 \%$ & $-716,76$ \\
\hline Losartana & 442 & 150 & -292 & $-66,06 \%$ & $-718,90$ \\
\hline Sinvax & 121 & 30 & -91 & $-75,21 \%$ & $-818,09$ \\
\hline Bonalen & 102 & 81 & -21 & $-20,59 \%$ & $-213,68$ \\
\hline
\end{tabular}

Fonte: A pesquisa

\section{CONSIDERAÇÕES FINAIS}

O estudo dos modelos de previsão de demanda para a drogaria apresenta resultados satisfatórios. Caso o melhor modelo, detectado no estudo, fosse utilizado na empresa, reduziriam - se os excessos de produtos em estoque e a falta de compra de outros.

Os modelos de suavização exponencial foram os que mais se ajustaram às características da empresa, com os menores desvios absolutos médios (DAM), sendo que o melhor alfa foi o de 0,5, observando que quanto maior o peso do último resultado, melhor será a previsão.

Observou-se na empresa um modelo de previsão pouco eficiente, pois nos períodos analisados os produtos foram comprados a mais do que utilizados, ou comprados a menos do que foram vendidos com diferença de no mínimo $20,59 \%$ até $414 \%$ do consumo real. O medicamento Glifage foi comprado
4.611 unidades a mais do que o vendido, o Sinvastamed deixado de comprar 220 unidades, o Losartana 292 unidades a menos, - Sinvax 91 unidades que não foram compradas, e 21 unidades a menos do que vendido do produto Bonalen. O produto que maior se distorceu da realidade foi o Glifage, que teve um custo de erro de $\mathrm{R} \$ 26.863,69$, produto comprado a mais do que comercializado e $\mathrm{R} \$ 2.467,43$ entre os produtos que não foram comprados por falta de previsão.

Conclui-se que a má previsão de demanda pode trazer gastos desnecessários à empresa bem como perder novas oportunidades de negócio. A imobilização de recursos em estoque desnecessariamente, como ocorreu com o produto Glifage, poderia ser aplicado em outros produtos ou no mercado financeiro. Por se tratarem de produtos de alta prioridade como os medicamentos, é de suma importância que não se deixe faltar nem que haja sobra desses mesmos, uma vez que são 
produtos que possuem uma alta perecibilidade acabam acarretando custos de estoques e financeiros para a empresa.

previsibilidade variável de demanda. Tese de Doutorado. Universidade de São Paulo, 2007. Disponível em: $<$ http://www.teses.usp.br/teses/disponiveis/3/3136/t de-27072007-181506/en.php>. Acesso em 14 mar. 2015.

[9]. MOTTA, Glaucia Possas et al. Uma análise dos impactos econômicos do Programa Farmácia Popular do Brasil. Disponível em: <http://www.anpec.org.br/encontro/2013/files_1/i12e75ad295e5f96a014e11b00bd2226ab7.pdf>. Acesso em: 02 jun. 2015.

[10]. NOVAES, Antônio Galvão. Logística e gerenciamento da cadeia de distribuição. 3. ed. Rio de Janeiro: Elsevier, 2007.

[11]. PEREIRA, Salomão Almeida et al. Estudo comparativo entre modelos de previsão de demanda: ensaio em um produto classe a de uma empresa de perfumes e cosméticos. In: ENEGEP, 16., 2006, Fortaleza. Congresso 09-11 out. 2006. p. 1 - $10 . \quad$ Disponível em: <http://www.simpep.feb.unesp.br/anais/anais_13/ar tigos/984.pdf>. Acesso em: 01 jun. 2015.

[12]. SILVA, André Furtado. Definição de um modelo de previsão das vendas da rede varejista Alphabeto. 2008. 49 f. Monografia - Curso de Engenharia de Produção, Universidade Federal de Juiz de Fora, Juiz de Fora, 2008. Disponível em: <http://www.ufff.br/ep/files/2014/07/2008_3_André. pdf>. Acesso em: 02 jun. 2015.

[13]. SILVA, D. A. M.; OLIVEIRA, P. A. Comparação entre métodos de previsão de demanda aplicados a fios cirúrgicos utilizados em um hospital escola do município de Botucatu. Revista Tekhne e Logos, Botucatu, SP, Vol. 3, n. 3, Novembro,

2012.

[8]. FREIRE, G. Estudo comparativo de modelos de estoques num ambiente com 


\section{Capítulo 11}

\section{PROCESSO DE COMPARTILHAMENTO DE CONHECIMENTO EM EQUIPES VIRTUAIS DE TRABALHO NO CENÁRIO BRASILEIRO}

\section{Roberta de Oliveira Cabrera \\ Ieda Ribeiro \\ Marília Macorin de Azevedo \\ Napoleão Verardi Galegale \\ José Manoel Souza das Neves \\ Marcelo Duduchi Feitosa}

Resumo: A transformação dos sistemas produtivos, juntamente com o processo de compartilhar o conhecimento tornaram-se mandatórios para a vantagem competitiva nas organizações, principalmente em ambientes de equipes virtuais. No contexto brasileiro, as mudanças da lei trabalhista e incentivos a tele-atividades fortaleceram as discussões sobre a importância do teletrabalho e da gestão do conhecimento. Neste cenário, mensurar como se dá a efetividade do processo de compartilhamento de conhecimento, se torna importante. De acordo com os fatos relatados, a questão de pesquisa trata: qual o impacto das variáveis confiança, motivação, cultura organizacional, participação, comunicação, gerenciamento de mudança e tecnologia, no processo de compartilhamento do conhecimento nas empresas brasileiras com ambiente de equipes virtuais? O objetivo é identificar como as variáveis (citadas acima) impactam no processo de compartilhamento de conhecimento em equipes virtuais nas empresas brasileiras. O método utilizado baseia-se em pesquisas conceitual, com base na literatura existente, descritiva e com levantamento de dados por meio de entrevistas com especialistas em teletrabalho (as respostas foram avaliadas pelo método de análise de conteúdo). Nota-se que as variáveis mencionadas impactam o compartilhamento de conhecimento, entretanto, ainda é um processo complexo e pouco claro nas organizações.

Palavras-chave: Equipes virtuais, Teletrabalho, Compartilhamento do conhecimento, Gestão do conhecimento, Sistemas produtivos. 


\section{INTRODUÇÃO}

A relevância do tema deve-se a transformação do mundo em virtude da globalização e da internet, criando novas formas de comunicação e, com isso, novas formas de trabalho e relacionamentos. O conhecimento torna-se um fator de competitividade, a necessidade de compartilhamento de informações entre empresa, colaborador e cliente, e vice e versa, é uma constante no cenário corporativo.

No Brasil, desde 1999, a SOBRATT (Sociedade Brasileira de Teletrabalho e Teleatividades), sociedade civil, sem fins lucrativos, reconhece e certifica as empresas que realizam o teletrabalho. Mas o papel do teletrabalho ganhou destaque a partir de 13 de Julho de 2017, quando foi sancionada a Lei n 13.467 que altera a Consolidação das Leis do Trabalho (CLT), a fim de adequar a legislação às novas relações de trabalho, e regulando o teletrabalho.
Com base na revisão da literatura, foram pesquisadas as sub áreas que envolvem a gestão de conhecimento: a criação, codificação/ armazenagem, compartilhamento e utilização do conhecimento. A área escolhida como objeto de estudo deste artigo é o compartilhamento de conhecimento.

O processo de compartilhamento é explicado pelas teorias: intercâmbio social (Social Exchange Theory), ideologia do intercâmbio (Ideology Exchange Theory), de motivação e memória transativa (Transactive Memory). Os desafios descritos para compartilhar o conhecimento em equipes virtuais são: confiança, motivação, comunicação, gerenciamento da mudança, participação e tecnologia. Os indicadores não foram considerados variáveis que impeçam o compartilhamento do conhecimento, entretanto, entende-se que são relevantes no presente estudo.

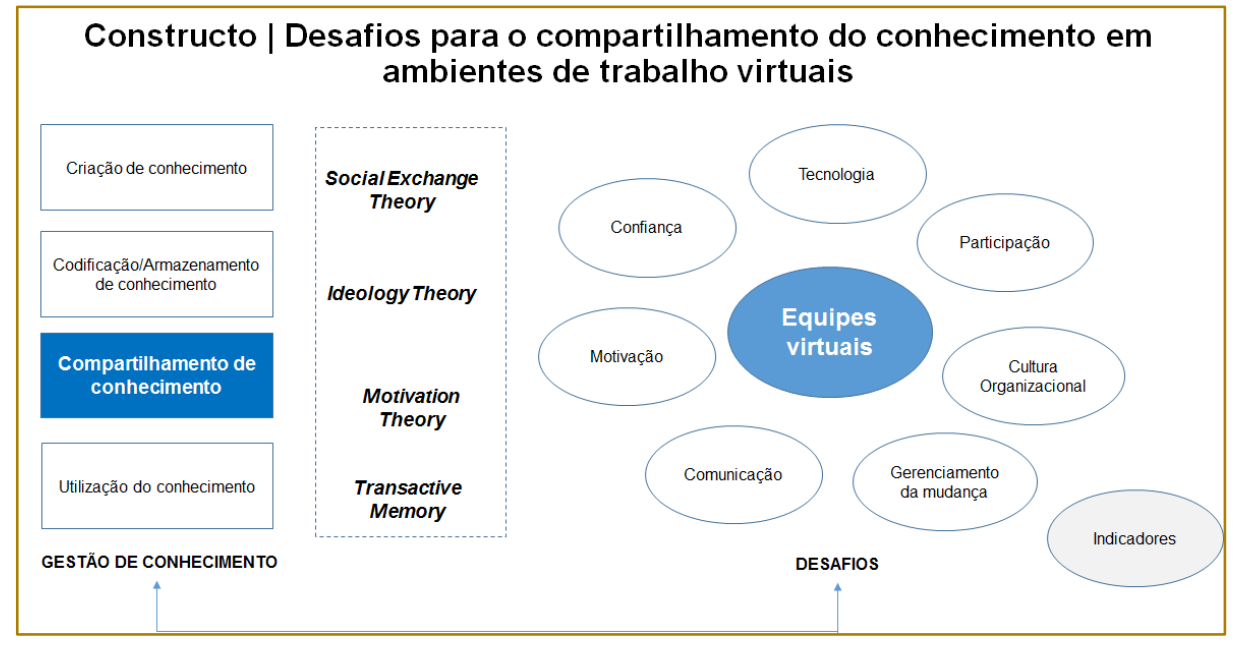

Fonte: Elaborado pelos autores

Com base no constructo, as hipóteses do trabalho são:

H1 - A confiança é um dos pilares para o compartilhamento do conhecimento no ambiente de equipes virtuais.

$\mathrm{H} 2$ - A cultura organizacional influencia o processo de compartilhamento do conhecimento em times virtuais

H3 - A motivação influencia o compartilhamento do conhecimento no ambiente virtual.
H4 - A liderança é um fator de influência no processo de compartilhamento de conhecimento para equipes que não estão no mesmo local físico.

H5 - A tecnologia é um fator chave para que o indivíduo compartilhe conhecimento.

H6 - O gerenciamento de mudanças deverá ser persistente para equipes virtuais

$\mathrm{H} 7$ - Existem indicadores que comprovam o processo de conhecimento compartilhado nas organizações brasileiras. 
Diante dos fatos relatados, a questão de pesquisa do artigo é: Como as variáveis confiança, motivação, cultura organizacional, participação, comunicação, gerenciamento de mudança e tecnologia impactam no processo de compartilhamento do conhecimento nas empresas brasileiras em ambiente de equipes virtuais? A relação entre as variáveis são: a variável independente são as equipes virtuais e a variável dependente é o conhecimento compartilhado.

O objetivo geral do trabalho é identificar como as variáveis confiança, motivação, cultura organizacional, participação, comunicação, gerenciamento de mudança e tecnologia que impactam no processo de conhecimento compartilhado de equipes virtuais nas empresas brasileiras.

Os objetivos específicos são:

Apresentar as teorias relacionadas à gestão do conhecimento, mais especificamente, sobre o processo de compartilhamento.

Identificar as variáveis que impactam o processo de compartilhamento de conhecimento.

Entender o cenário de equipes virtuais de trabalho.

\section{EMBASAMENTO TEÓRICO OU REVISÃO DA LITERATURA}

\subsection{EQUIPES VIRTUAIS E TELETRABALHO}

Lipnack e Stamps (1994, p. 14), já apresentavam na década de 90, o conceito de equipes virtuais, com o nome de teamnet com a definição de redes de equipes, utilizadas pelas empresas para conduzir negócios, ultrapassando as fronteiras internas e externas da organização.

Gibson e Cohen (2003, p. 4) definem uma equipe como virtual por três atributos: é uma equipe funcional e interdependente, que compartilha a responsabilidade pelos resultados; constituem uma unidade social intacta incorporada em um ou mais sistemas sociais e os membros da equipe estão dispersos geograficamente. A equipe depende de comunicações mediadas pela tecnologia e não de face-a-face para realizar suas tarefas.

Uma equipe virtual (teamnet) de sucesso tem como características, de acordo com Lipnack e Stamps (1994, p. 32): propósito claro (missão); pessoas independentes e comprometidas com a missão; sistema de interligação e redes de relacionamento (email, chat, por exemplo); multiplicidade de líderes e interação entre diferentes níveis.

Com base nos fatores considerados críticos para o sucesso das equipes virtuais, Ferreira (2014, p. 150) menciona os atributos compreendidos por elas como:

- Confiança: boa-fé, comprometimento dos membros da equipe, honestidade e sentimento de coletividade.

- Liderança e gestão de conflitos: liderança que motiva, que constrói o entusiasmo, que é eficiente e positiva.

- Comportamento do indivíduo e cultura organizacional: os membros estão comprometidos com o projeto, seguem as normas predefinidas, agem com iniciativa e proatividade e são interdependentes.

- Ferramentas de controle: a equipe segue os processos e normas do trabalho, há a contribuição de ferramentas de desempenho e de controle da motivação.

- Comunicação: desenvolvimento da equipe em função das oportunidade de comunicação, velocidade da troca de informações e a falta de informação pode construir estereótipos. Há também uma preocupação na previsibilidade e frequência da comunicação. Além de identificar um padrão, tanto na natureza quanto nos canais de comunicação.

- Gestão do conhecimento: utilização da experiência dos membros que já trabalharam em equipes virtuais, sistema de identificação de quem faz o que e quando, sistemas de coordenação e credibilidade entre os membros da equipe.

- Organização e estrutura: escritório de gerenciamento de projeto, participação do patrocinador no desempenho da equipe e sistema claro de recompensa para a equipe.

Gonçalves et al (2014, p. 4) afirmam que a superação das barreiras do tempo e do espaço foram ultrapassadas pela tecnologia, de modo que a comunicação tornou-se computadorizada: da videoconferência ou da conferência por computador, que pode ser pensada como a comunicação tradicional, face a face de hoje, até as interfaces virtuais de comunicação e ambientes, onde existe um mundo simulado por computador entre os interlocutores. 
As equipes virtuais estão mudando o panorama corporativo do século XXI, substituindo as equipes tradicionais (presenciais) e possibilitando às empresas enfrentarem os novos desafios de projetos mais complexos e dinâmicos (PONTES, OLIVEIRA e RAMOS, 2015, p. 428).

De acordo com International Labour Office (2016, p. 3), uma das definições de teletrabalho é a modalidade de trabalho que pode ser realizada:

- por meio de localização remota de escritórios centrais ou instalações de produção separando, assim, o trabalhador de contato pessoal com colegas e;

- a nova tecnologia permite esta separação facilitando a comunicação. Além disso, o teletrabalho poderia ser "on-line" (com o uso do computador) ou "offline", que seja organizado individualmente ou coletivamente e que constitua o todo ou parte das atividades de um trabalhador.

Segundo a cartilha da Sociedade Brasileira de Teletrabalho e Teleatividades - SOBRATT, (2016, p. 10):

\section{O teletrabalho é toda modalidade de trabalho intelectual, regido por um contrato realizado à distância e fora do local sede da empresa, com a utilização de tecnologias de comunicação e informação (computadores, tablete ou smartphones, usando internet, banda larga, telefonia fixa e/ ou móvel, entre outros), que permitam receber e transmitir dados, arquivos de texto, imagem ou som, mediante controle, supervisão e subordinação.}

No Brasil, com as alterações previstas no decreto-lei 13.467 de 13 de julho de 2017, a CLT prevê um capítulo exclusivo sobre o teletrabalho (Capítulo II-A do Teletrabalho)

O teletrabalho e equipes virtuais são vistos como inovações com potencial para efetivamente responder a ambientes turbulentos de negócios a qualquer momento e em qualquer lugar de trabalho. O teletrabalho pode ser definido como o trabalho em tempo integral, remoto, na casa de uma pessoa ou numa equipe virtual constituída por um grupo de teletrabalhadores que utilizam uma infraestrutura composta de uma gama de informações e tecnologias que apoiam o trabalho, como e-mail, telefone, sistemas de videoconferência, entre outros (WORKMAN, KAHNWEILER E BOMMER, 2001, p. 199).

\subsection{GESTÃO DE CONHECIMENTO}

De acordo com Alavi e Tiwana (2002, p. 1029), o sistema de gestão de conhecimento está dividido em: criação, codificação e aplicação. O processo de criação refere-se a um novo conhecimento que, muitas vezes, surge na resolução de problemas em equipes. A codificação compreende a fase de formalização do conhecimento por meio de softwares, manuais de instruções (por exemplo). A fase de aplicação do conhecimento é a de maior valia, pois somente quando o conhecimento é distribuído em toda a organização, que ele se mostra necessário.

O processo de criação, codificação e armazenamento de novos conhecimentos sem a sua exploração, leva-os à subutilização. As organizações que se destacam na aplicação do conhecimento são inerentemente melhores pois traduzem a inovação de seu capital intelectual (ALAVI e TIWANA, 2002, p. 1030).

De acordo com Ożga e Stelmaszczyk (2016), o conhecimento é um componente básico de todas as organizações. É percebido como uma das fontes mais importantes de vantagem competitiva. Os benefícios incluem a falta de limitações geográficas ao empregar especialistas de várias disciplinas e a capacidade de baixar os custos tanto por uma organização criando uma equipe virtual, quanto pelos membros dessa equipe. Também significa formas mais ativas de apoiar a criatividade e a originalidade, resultando em um nível mais alto de inovação, flexibilidade e eficiência em comparação com os times tradicionais.

Os tipos de conhecimento que são tratados por Nonaka (1994, p. 16) são o conhecimento explícito e o tácito. O conhecimento explícito ou codificado refere-se ao conhecimento que é transmissível de maneira formal, linguagem sistemática. Por outro lado, o conhecimento tácito tem uma qualidade pessoal, o que dificulta a formalização e a comunicação. Este tipo de conhecimento é profundamente enraizado em ação, compromisso e envolvimento em um contexto específico.

De acordo com Wu, Lin e Lin (2006, p.3) o conhecimento tácito não pode ser expresso de forma simbólica, verbal e escrita, enquanto o conhecimento explícito existe na forma simbólica e escrita. 
O conhecimento tácito envolve elementos cognitivos e técnicos. Os elementos cognitivos referem-se a imagens individuais da realidade e visões para o futuro. Enquanto que os elementos técnicos referem-se a habilidades dos indivíduos quanto a conhecimentos concretos, trabalhos manuais e outras habilidades que se aplicam a contextos específicos. Portanto, a comunicação entre os indivíduos pode ser visto como um processo analógico que visa compartilhar conhecimento tácito para construir relações mútuas de compreensão (NONAKA, 1994, p. 16).

Conforme a visão de Takeuchi e Nonaka (2008, p. 19):

\section{O conhecimento explícito pode ser expresso em palavras, números ou sons, e compartilhado na forma de dados, fórmulas científicas, recursos visuais, especificações de produtos ou manuais. O conhecimento explícito pode ser rapidamente transmitido aos indivíduos, formal e sistematicamente. Entretanto, o conhecimento tácito não é facilmente visível e explicável. É altamente pessoal e difícil de formalizar, tornando-se de comunicação e compartilhamento dificultoso. As intuições e os palpites subjetivos estão sob a rubrica do conhecimento tácito. O conhecimento tácito está profundamente enraizado nas ações e na experiência corporal do indivíduo, assim como nos ideais, valores ou emoções que ele incorpora.}

A criação do conhecimento inicia com a socialização e passa através de quatro modos de conversão do conhecimento, formando uma espiral. O conhecimento é amplificado passando pelos quatro modos de conversão, que podem ser descritos, por Takeuchi e Nonaka (2008, p. 23) como:

a) Socialização: Compartilhar e criar conhecimento tácito através de experiência direta.

b) Externalização: Articular conhecimento tácito através do diálogo e da reflexão.

c) Combinação: Sistematizar e aplicar o conhecimento explícito e a informação.

d) Internalização: Aprender e adquirir novo conhecimento tácito na prática.

Para Takeuchi e Nonaka (2008, p. 19), "o conhecimento não é explícito ou tácito. O conhecimento é tanto explícito quanto tácito. O conhecimento é inerentemente paradoxal, pois é formado do que aparenta ser dois opostos".

Nonaka (1994, p.24) menciona que trocar ideias por meio de narrativas compartilhadas e histórias de vida podem fornecer uma plataforma importante para construir uma compreensão compartilhada de conflitos e dados que estão confusos na equipe.

Lee (2001, p. 324) conceitua o compartilhamento do conhecimento como as atividades de transferência e disseminação do conhecimento de uma pessoa, grupo ou organização para outro. Esta definição engloba tanto o conhecimento tácito quanto o explícito.

O processo de compartilhamento de conhecimento entre indivíduos envolve a conversão do conhecimento realizado por um indivíduo em uma forma que pode ser entendida, absorvida e usada por outros indivíduos (PANGIL e CHAN, 2014, p. 97).

\subsection{TEORIAS DE COMPARTILHAMENTO DE CONHECIMENTO}

De acordo com Chen at al (2009, p. 2) a teoria do intercâmbio social (do inglês, Social Exchange Theory) descreve que indivíduos apresentam interação social não só para recompensas (por exemplo, pagamento, bônus), mas para recompensas sociais, como aprovação e respeito. No intercâmbio social, os recursos cedidos pelos indivíduos podem ser vistos como custos, enquanto os recursos recebidos, como benefícios. O compartilhamento do conhecimento caracteriza-se como uma troca social envolvendo a provisão de experiência e esforço de codificação em troca de benefícios econômicos e sociais. Estudos descobriram que a alta percepção de benefícios irão aumentar o processo de compartilhamento individual. Nas equipes virtuais, a teoria do intercâmbio social também foi mostra-se útil com o processo de troca pessoa-equipe. No contexto virtual, os benefícios econômicos são representados como recompensas extrínsecas, refletindo benefícios explícitos Os benefícios sociais são representados pela autoestima e relações recíprocas, refletindo a medida em que os indivíduos percebem como outros membros mostram preocupação com eles.

De acordo com a teoria de intercâmbio social, a confiança interpessoal estará positivamente associada à quantidade de 
compartilhamento. O intercâmbio social depende fortemente da confiança porque envolve não especificado obrigações que não podem ser aplicadas (ou seja, não há contrato vinculativo). No conhecimento, a confiança interpessoal entra em jogo porque os requerentes devem se permitir ser vulneráveis para seus colegas, por exemplo, reconhecendo sua falta de conhecimento. Os requerentes também podem precisar confiar que seus colegas fornecerão informações precisas e úteis. (STAPLES; WEBSTER, 2008, p. 621)

A teoria do intercâmbio de ideologia (/deology Exchange Theory) de Einsenberg et al (1986, p. 501), a ideologia adere fortemente à norma de reciprocidade, acreditando que os indivíduos devem ajudar aqueles que os ajudam. Os relacionamentos são mais positivos para os membros das equipes que possuem uma ideologia de troca mais forte (SCOTT e COLQUITT, 2007, p. 296). Os empregados com maior índice de ideologia individual requerem a maior recompensa e terão altos níveis de compartilhamento de conhecimento. Entretanto, para os funcionários com baixo índice de ideologia individual, a maior recompensa não aumentará o nível de compartilhamento de conhecimento, devido à sua moral e sentido de obrigação. Com base no exposto, esperase que o efeito positivo da recompensa no comportamento do processo de compartilhamento seja mais forte para pessoas com ideologia individual de troca alta do que para pessoas com baixa (ZHANG, 2011, p. 31).

Na concepção de Lin (2007, p. 137), a teoria da motivação é identificada como um determinante chave do comportamento geral, da aceitação da tecnologia da informação e do comportamento relacionado ao trabalho. Há uma indicação de que a motivação é o principal gatilho para transferência de conhecimento. A motivação divide-se em extrínseca e intrínseca. A motivação extrínseca concentra-se nas razões orientadas por objetivos, e recompensas ou benefícios obtidos ao realizar uma atividade, enquanto a motivação intrínseca indica o prazer e a satisfação inerente derivado de uma atividade específica. Juntas, a motivação extrínseca e intrínseca influenciam individualmente as intenções em relação a uma atividade, bem como comportamentos reais das pessoas. A motivação extrínseca do empregado para compartilhar conhecimento é uma crença de resultado que normalmente é baseada em percepções dos funcionários sobre o valor da associação com o intercâmbio de conhecimento. Por exemplo, os funcionários se envolvem em troca de conhecimento com base em uma análise custo-benefício, comparando a recompensas (benefícios) esperadas de uma troca com o esforço (custos) envolvido nessa troca. Do ponto de vista socioeconômico, se os benefícios percebidos forem iguais ou superiores aos custos, então, o processo de troca continuará, caso contrário parará. No contexto do compartilhamento de conhecimento, os custos incluem fatores relacionados ao esforço (por exemplo, tempo gasto, esforço mental, etc.), enquanto os ganhos potenciais incluem receber recompensas organizacionais ou criar obrigações para que os colegas possam corresponder. A motivação intrínseca referese a se envolver em uma atividade por sua causa, por interesse ou pelo prazer e satisfação derivados da experiência. Por exemplo, através do compartilhamento de conhecimento, os funcionários podem ser satisfeitos aumentando sua autoeficácia de conhecimento ou confiança em seus colegas e capacidade de fornecer conhecimento que seja útil para a organização.

A memória transativa é um mecanismo cognitivo que permite a comunicação entre os membros da equipe. Ela permite aos indivíduos o conhecimento tácito na resolução da tarefa coletiva. Além disso, a memória transativa fornece aos indivíduos a capacidade de procurar o conhecimento necessário para completar uma determinada tarefa da equipe.Os indivíduos podem usar essa memória para acessar e recuperar conhecimento que não é conhecido pessoalmente para eles, mas que eles reconhecem como existentes em outros lugares da organização. (ALAVI, 2002; CHEN et al, 2013).

Alguns instrumentos para o compartilhamento de conhecimento no sistema de memória transativa podem ser: mapas de conhecimento ou perfis de membros da equipe especificando sua área de especialização (diretórios que capturam e inventariam o conhecimento, a experiência e os antecedentes dos membros de equipes virtuais); bibliotecas pesquisáveis de conhecimento codificado relevantes à tarefa de equipe; quadros de avisos eletrônicos onde os membros da equipe podem enviar 
perguntas e procurar outra equipe para assistência e conhecimento dos membros; repositórios de conhecimento on-line; hardware e software de Groupware, redes de informação e comunicação; intranet e portais; fórum de discussão, videoconferência; chat, listas de e-mail (ALAVI, 2002; SANTOS, 2010, p. 45).

\subsection{VARIÁVEIS ENVOLVIDAS NO COMPARTILHAMENTO DO CONHECIMENTO NAS EQUIPES VIRTUAIS}

O comportamento de compartilhamento de conhecimento é visto como o grau em que os membros da equipe virtual realmente compartilham seus conhecimentos mútuos com colegas para tarefas de projeto. As equipes virtuais sempre enfrentam um problema crônico com falta de conhecimento compartilhado, mesmo com a disponibilidade de tecnologia da informação e comunicação (ZHANG e CHEN, 2010, p. 349).

Davenport e Prusak (1998, p. 24), abordam alguns princípios do compartilhamento de conhecimento em equipes virtuais:

- O conhecimento é produzido e reside na mente das pessoas;

- O ato de compartilhar conhecimentos requer confiança;

- A tecnologia permite novos comportamentos;

- O processo de compartilhamento de conhecimento deve ser encorajado e premiado;

- O suporte da gerência e recursos são fundamentais;

- As iniciativas de conhecimento deveriam começar com um teste-piloto;

- As métricas quantitativas e qualitativas são necessárias para avaliar as iniciativas.

Moe et al (2016, p. 30), no mundo em constantes mudanças organizacionais, a estrutura requer flexibilidade e equipes virtuais fluidas com membros rotativos. Este tipo de mudança organizacional não permite a estabilidade da equipe, e requer um foco constante no desenvolvimento do conhecimento da equipe no ambiente virtual. O fortalecimento do conhecimento da equipe deve ser feito durante todo o tempo. Embora o conhecimento compartilhado seja essencial, nem todas as equipes conseguem a construção de uma compreensão conjunta. Desenvolver o conhecimento do time em uma equipe globalmente distribuída é mais desafiador do que em uma equipe alocada. Os desafios são: a cultura, barreiras linguísticas, valores e hábitos diferentes, falta de comunicação face a face, fusos horários e dificuldades em construir e manter a confiança.

\section{DESENVOLVIMENTO DA TEMÁTICA}

O método utilizado será teórico-conceitual, com pesquisa descritiva. A pesquisa será bibliográfica com abordagem qualitativa e utilização de levantamento de dados por meio de questionários estruturados com especialistas em teletrabalho e gestão de equipes virtuais As entrevistas tem como finalidade validar as variáveis levantadas na literatura que impactam no processo de conhecimento compartilhado. A análise de conteúdo (content analysis), proposta por Kripendorff (2004) foi a técnica utilizada para analisar as respostas dos questionários para garantir a replicabilidade e inferência dos resultados. A respostas foram analisadas duas vezes por uma pesquisadora e separadamente pela outra pesquisadora. Em seguida foi feita uma análise conjunta.

Foi utilizada a bibliometria para definição de quais artigos constituiriam a base teórica. As bases utilizadas foram: Science Direct, Web Of Science e IEEE Xplore. As palavras-chave para a busca foram: compartilhamento (compartilhar), transferência e difusão do conhecimento; e equipes virtuais. As buscas foram realizadas tanto em português quanto em inglês. Os resultados exibidos pelas bases foram: Web of Science: 32 resultados; Science Direct. 148 resultados; e IEEE Xplore: 13 resultados; totalizando 193 resultados.

As principais palavras-chave encontradas foram: virtual team(s) (23), knowledge sharing (19), knowledge management (17), trust (10), global virtual teams (5), collaboration (5), innovation (5), virtual enterprises (5) e knowledge transfer (4).

Nota-se que as publicações sobre equipes virtuais e gestão do conhecimento tornaramse recorrentes nos últimos 10 anos.

Foi realizada pesquisa com questionário estruturado, perguntas abertas, para especialistas em teletrabalho (consultores, gestores de recursos humanos e de equipes 
virtuais de empresas nacionais multinacionais). O questionário foi elaborado por meio do Survey Monkey e foi enviado por e-mail no período de 14 de novembro a 25 de novembro de 2017.

\section{RESULTADOS E DISCUSSÃO}

A gestão do conhecimento é um fator chave para os processos de criação, disseminação e utilidade do conhecimento para as equipes virtuais. A preocupação das empresas é de cada vez mais reduzir as barreiras para que o conhecimento seja compartilhado na organização atingindo todos os colaboradores.

No artigo foram testadas hipóteses, algumas que se confirmaram e outras foram parcialmente rejeitadas, pela abordagem da literatura e também por meio da pesquisa realizada com especialistas e executivos:

H1 - A confiança é um dos pilares para o compartilhamento do conhecimento no ambiente de equipes virtuais. O elemento mostrou-se fundamental para o processo de compartilhamento em ambientes virtuais.

$\mathrm{H} 2$ - A cultura organizacional influencia o processo de compartilhamento do conhecimento em times virtuais. A cultura organizacional que, de certa forma, engloba a cultura nacional, idioma e costumes é apontada como um item de grande importância.

H3 - A motivação influencia o compartilhamento do conhecimento no ambiente virtual. A motivação, seja influenciada por reconhecimento pessoal ou recompensas extrínsecas foi um item de alta relevância.

H4 - A liderança é um fator de influência no processo de compartilhamento de conhecimento para equipes que não estão no mesmo local físico. A liderança não foi abordada com muita ênfase na literatura e na visão dos especialistas.

H5 - A tecnologia é um fator chave para que o indivíduo compartilhe conhecimento.A tecnologia é um item levado em consideração, mas não é classificado com alto grau de importância.

H6 - O gerenciamento de mudanças deverá ser mais persistente para equipes virtuais. $\mathrm{O}$ gerenciamento de mudanças é abordado no contexto da motivação para influenciar a mudança de comportamento dos membros da equipe virtual. É um item importante especialmente para equipes que não estão no mesmo local físico.

H7 - Existem indicadores que comprovam o processo de conhecimento compartilhado nas organizações brasileiras. De acordo com a literatura e com a visão dos especialistas, as empresas não parecem ter indicadores para comprovar se o compartilhamento é efetivo. São conferidos indicadores atitudinais com base em KSAs (Knowledge, Skills and Abilities) para mensurar o desempenho da equipe.

\section{CONSIDERAÇÕES FINAIS}

A questão de pesquisa que o trabalho apresentou foi: Qual o impacto das variáveis confiança, motivação, comunicação, gerenciamento da mudança, participação e tecnologia no processo de compartilhamento do conhecimento nas empresas brasileiras em ambiente de equipes virtuais? Esta foi respondida por meio de abordagem da literatura e validada na visão dos especialistas em teletrabalho/ equipes virtuais.

As limitações da pesquisa foram: amostra de dados restrita com somente dez especialistas e não foram considerados o porte da empresa e número de funcionários, somente a experiência com gestão de equipes virtuais e teletrabalho dos especialistas.

Como contribuições para futuras pesquisas, recomenda-se a investigação de se há indicadores de desempenho que possibilitam mensurar o compartilhamento de conhecimento e sua efetividade no processo. 


\section{REFERÊNCIAS}

[1]. ALAVI, M; TIWANA, A. Knowledge Integration in Virtual Teams: The Potential Role of KMS, 2002. Journal of the American Society for Information Science and Technology, 53(12):1029$1037 \mathrm{p}$.

[2]. BOCK, G-W; KIM, Y-G. Breaking the Myths of Rewards: An Exploratory Study of Attitudes about Knowledge Sharing, 2001. Pacific Asia Conference on Information Systems (PACIS), 2011.

[3]. BRASIL. Consolidação das Leis Trabalhistas. Lei № 13.467, de 13 de julho de 2017. Disponível http://www.planalto.gov.br/ccivil_03/_ato20152018/2017/lei/L13467.htm, Acesso em: 17 nov. 2017.

[4]. CHEN, Z. et al. Encouraging knowledge sharing in global virtual teams: the interaction effect of individual difference and perceived sharing benefits, 2009. Proceedings of the 42nd Hawaii International Conference on System Sciences.

[5]. CHEN, X. et al. Knowledge sharing in open source software project teams: A transactive memory system perspective, 2013. International Journal of Information Management n. 33, 553563p.

[6]. DAVENPORT, T.H. AND PRUSAK, L., Working Knowledge: how organizations manage what they know, Harvard Business School Press, Boston, MA, 2008.

[7]. EBRAHIM, N. A.; A., SHAMSUDDIN; TAHA, Z. Virtual Teams: a Literature Review. Australian Journal of Bas IC and Applied Sciences, 3(3): 2653-2669 p, 2009.

[8]. EINSENBERG, R. et al. Perceived Organization Suport, 1986. Journal Applied Psychology, n. 71, n.3, $500-507 p$.

[9]. FERREIRA, A. M. D. Fatores críticos na gestão de projetos com equipes virtuais: uma visão global. Escola Politécnica da Universidade de São Paulo, 2014, 179 p.

[10]. GAO, S.; GUO, Y; CHEN, J.; Lin, L. Factors affecting the performance of knowledge collaboration in virtual team based on capital appreciation, 2015. Inf Technol Management.

[11]. GIBSON, C.B; COHEN, S. G. Virtual teams that work: creating conditions for virtual team effectiveness. São Francisco: Jossey Bass, 2003.

[12]. GONÇALVES, P. et al. Direct Communication versus Virtual Communication in Virtual Teams. Procedia Technology, v. 16, 3-10 p, 2014

[13]. HOLSTE, J. S.;FIELDS, D. Trust and tacit knowledge sharing and use, 2010. Journal of Knowledge Management, v. 14, n. 1, 128-140p.
[14] KAUPPILA, O. P.; RAJALA, R.; JYRÄMÄ A. Knowledge sharing through virtual teams across borders and boundaries, 2011. Management Learning. 42 (4) 395-418 p.

[15]. KRIPPENDORFF, K. Content Analysis: an Introduction to Its Methodology, 2nd Edition,Thousand Oaks, CA: Sage Publications, 2004.

[16]. LEE, J. N. The impact of knowledge sharing, organizational capability and partnership quality on IS outsourcing success (2001). Information \& Management, n. 38, 323 - 335p.

[17]. LIN, H-F. Effects of extrinsic and intrinsic motivation on employee knowledge sharing intentions, 2007. Journal of Information Science, 33 (2), 135-149p.

[18]. LIPNACK, Jessica; STAMPS, Jeffrey. Rede de Informações. São Paulo: Makron Books, 1994.

[19]. LUCAS, L. M. The impact of trust and reputation on the transfer of best practices, 2005, v. 9, n, 4, Journal of Knowledge Management, 87$101 p$.

[20]. MCLAUGHLINY, S.; PATON, R. A. Defining a Knowledge Strategy Framework for Process Aligned Organizations: an IBM Case (2008). Knowledge and Process Management, v. 15, n. 2, 126-139 p.

[21]. MOE, N. B., et al. Enabling knowledge sharing in agile virtual teams, 2016. IEEE 11th International Conference on Global Software Engineering, 29-33p.

[22]. NONAKA, I. A dynamic theory of organizational knowledge creation (1994). Organization Science, vol. 5, n. 1, fev, 1994, 14 37p.

[23]. OLAISEN, J.; REVANG, O. Working smarter and greener: Collaborative knowledge sharing invirtual global project teams, 2017. International Journal of Information Management, $\mathrm{n}$. 37, 1441-1448p.

[24]. OżGA, J.; STELMASZCZYK, M. The role of internal change agent in developing the relationship between knowledge sharing and performance in virtual team, 2016. disponível em: http://www.e-

mentor.edu.pl/artykul/index/numer/67/id/1272, acesso em: 10 de out. 2017.

[25]. PONTES, P. M; OLIVEIRA, S. B; A. C., RAMOS (FILHO). Gestão de Equipes Virtuais em Projetos de Desenvolvimento e Manutenção de Software: O Caso de uma Multifuncional de Tecnologia da Informação. Revista Eletrônica Sistemas \& Gestão, Vol. 10, 426-440, 2015. 


\section{Capítulo 12}

\section{PROPOSTA PARA O ARMAZENAMENTO IDEAL DE PRODUTOS ALIMENTICIOS COM ESPECIFICIDADES DE TEMPERATURA E UMIDADE: UM ESTUDO DE CASO EM UM REDEX NO MUNICIPIO DE CUBATÃO}

\section{Clayton Gerber Mangini}

\section{Claudio Melin Doná}

Julio Cesar Aparecido da Cruz.

Wagner Delmo Abreu Croce

Resumo: Esta pesquisa tem como objetivo demonstrar fatores que influenciam negativamente na manutenção de bens de consumo alimentícios, como café solúvel e derivados de leite enlatados. Para isso, faz-se necessário um estudo de caso através de equipamentos de monitoramento de temperatura e umidade, onde foram analisadas as necessidades dos produtos e qual sistema de armazenagem deve ser adotado. Os problemas centrais são os casos de oxidação das embalagens e a compactação de produto causado pela umidade e temperatura elevada. No Recinto Especial para Despacho Aduaneiro (REDEX), localizado na cidade de Cubatão, onde encontra-se a empresa estudada, onde o problema é agravado pelo índice de umidade relativa do ar observado no município. Propõese como solução para manter a integridade deste tipo de carga, a disponibilização de uma área com temperatura controlada proporcionando um acondicionamento adequado para os produtos, o que está em acordo com soluções tecnológicas utilizadas na logística, havendo desta forma uma contribuição para a academia, uma vez que esta pesquisa poderá ser utilizada por empresas que possuem a mesma dificuldade na armazenagem de seus produtos ou de terceiros.

Palavras-chave: Armazenagem. Cadeia do frio. REDEX 


\section{INTRODUÇÃO}

No mundo competitivo atual as empresas buscam novas tecnologias para melhorarem suas operações, pois todo tempo gasto com as operações logísticas geram custos e acabam sendo repassados para o produto final. E para ganhar a concorrência o produto precisa ser entregue com bom preço e com o menor tempo possível para satisfazer o cliente.

No caso da exportação de mercadorias, além dos tramites legais que envolvem 0 desembaraço da carga, tem mais um fator que interfere no tempo, a falta de espaço físico nos portos, dificultando o trânsito dentro do mesmo.

Para melhorar o fluxo de cargas na área portuária, que na maioria dos casos não tem mais para expandir, foram criadas alternativas para os exportadores despacharem suas cargas. Dentre elas está o Recinto Especial para Despacho Aduaneiro (REDEX) um local onde a carga é estufada em contêiner e inspecionada mesmo antes de chegar ao porto. A proximidade da instalação do mesmo com o local de exportação é um diferencial que faz com que as empresas escolham um em especial.

Cubatão é um ponto estratégico para a instalação, tanto pela proximidade com o Porto de Santos, quanto pelo fácil acesso pelas rodovias. No entanto, para estes produtos específicos, o clima do município não favorece sua utilização, pois os altos índices de umidade podem danificar a embalagem dos produtos, prejudicando sua qualidade e impossibilitando a exportação dos mesmos.

Para que o exportador possa utilizar essa armazenagem, fazem-se necessárias algumas modificações no local físico onde as mercadorias ficarão armazenadas até sua estufagem.

A busca deste estudo é destacar as alternativas para operações de exportação de Bens de Consumo com necessidades específicas de conservação; com a finalidade de entender como funciona a operação e relacionar as medidas de controle de umidade e temperatura para manter a integridade do produto e/ou embalagem, durante $\mathrm{o}$ processo de armazenagem e transporte até sua chegada em seu destino final. Com os resultados, a proposta é promover soluções para empresas que atuam na logística deste tipo de carga.

A questão a ser analisada é evidenciar a maneira encontrada para armazenar produtos alimentícios que sofrem alterações tanto na sua qualidade quanto na embalagem com umidade acima de 60\% no Município de Cubatão onde a média anual está em torno de $80 \%$, local onde está instalando o REDEX no qual a empresa estudada em questão quer armazenar esses produtos que são exportados pelo Porto de Santos. A localização do armazém é estratégica, pois sua proximidade com porto facilita os trâmites legais e agiliza o tempo gasto entre estufagem, inspeção e despacho para a exportação da carga.

Desse modo a pesquisa quer responder: Como armazenar de forma adequada produtos que sofrem alterações no seu conteúdo e ou suas embalagens (lata) por causa de altos índices de umidade relativa do ar e de temperatura?

Esta pesquisa tem como objetivo geral verificar as variações de temperatura e umidade que impactam em alguns produtos armazenados em um REDEX no Município de Cubatão. Desta forma, os objetivos específicos são: Identificar os produtos que serão armazenados e quais são suas necessidades especificas de acondicionamento, monitorar a temperatura e umidade do armazém e analisar os dados obtidos e sugerir uma solução a ser adotada.

Para a fundamentação foi utilizado o método de estudo de caso, onde os dados foram analisados de forma qualitativa, coletando informações obtidas através de equipamentos que monitoram a temperatura e umidade de ambientes, que neste caso resultou em um mapeamento em um armazém voltado à exportação.

Segundo Yin (2015), o estudo de caso tem sido utilizado amplamente nas pesquisas, sempre em casos orientados pela prática e de forma estratégica nas pesquisas de teses e dissertações.

Para escolher a estratégia de pesquisa, são consideradas três condições:

- Quais as questões básicas da pesquisa;

- Quanto o pesquisador tem de controle sobre os eventos comportamentais reais; 
- Quanto de destaque será dado aos eventos contemporâneos em contraposição aos eventos históricos.

Estas três condições estão relacionados com os cinco principais métodos de pesquisa: estudo de caso, pesquisas históricas, análises de arquivos, levantamentos e experimentos (YIN, 2015).

\section{EMBASAMENTO TEÓRICO OU REVISÃO DA LITERATURA}

\subsection{ARMAZENAGEM}

A armazenagem é constituída por um conjunto de funções de recepção, descarga, carregamento, arrumação e conservação de matérias-primas, produtos acabados ou semiacabados. Uma vez que este processo envolve mercadorias, será possível produzir resultados quando é realizada uma operação, nas existências em trânsito, com o objetivo de Ihes acrescentar valor. Pode-se definir a missão da armazenagem como o compromisso entre os custos e a melhor solução para as empresas. Na prática isto só é possível se levar em consideração todos os fatores que influenciam os custos de armazenagem, bem como a importância relativa dos mesmos.

Na prática, muitas vezes, a armazenagem é confundida com estocagem, o que não pode acontecer, porque cada uma tem funções diferentes, conforme definição de Moura (2005, p.20):

Armazenagem é a denominação genérica e ampla que inclui todas as atividades de um ponto destinado à guarda temporária e à distribuição de materiais (depósitos, almoxarifados, centros de distribuição, etc.) e estocagem é uma das atividades do fluxo de materiais no armazém e o ponto destinado à locação estática dos materiais. Dentro de um armazém podem existir vários pontos de estocagem. A estocagem é uma parte da armazenagem.

A armazenagem é a guarda temporária de produtos para posterior distribuição. Os estoques são necessários para o equilíbrio entre a demanda e a oferta. No entanto, as empresas visam manter níveis de estoques baixos, pois estes geram custos elevados: custos de 'pedir' - custos administrativos associados ao processo de aquisição das mercadorias; custos de 'manutenção' referentes a instalações, mão-de-obra e equipamentos; custos de 'oportunidade' associado ao emprego do capital em estoque (HONG, 1999).

\subsection{RECINTO ESPECIAL PARA DESPACHO ADUANEIRO (REDEX)}

Os regimes aduaneiros especiais são importantes, pois estimulam a economia com a desoneração de impostos, com o ritmo intenso do comercio exterior. O governo criou esse mecanismo para dinamizar o processo de saída e entrada de produtos no território aduaneiro com suspenção ou isenção de tributos, trazendo assim vantagens para os exportadores e importadores. Dentro dos quais destacamos o que é utilizado nesta pesquisa.

O Recinto Especial para Despacho Aduaneiro de Exportação (REDEX) é usado em alguns casos para melhorar o fluxo nos Portos, tendo em vista que a maioria dos portos do país não tem mais para onde expandir territorialmente, necessitando de alternativas para exportadores que querem movimentar suas mercadorias em menor tempo possível. Além de servir como armazém em um primeiro momento, o REDEX é utilizado para estufagem do produto em contêiner, local que é inspecionado pelos órgãos competentes do governo, diminuindo assim o tempo que o produto fica na área portuária e agilizando o processo de exportação. A Instrução Normativa da Secretaria da Receita Federal, no114, de 31 de dezembro de 2001, dispõe sobre a fiscalização no REDEX.

Segundo Rocha (2013), o uso do REDEX permite que cargas destinadas para exportação sejam despachadas no próprio recinto e sigam em trânsito aduaneiro, ou seja, as mercadorias estão sobre controle aduaneiro até sua chegada ao ponto em que os produtos embarquem sem a necessidade de sofrerem novamente os procedimentos aduaneiros. Para Martinez (2010), a utilização do REDEX, reduz sensivelmente os custos operacionais e administrativos, além da segurança e agilidade nos contratos internacionais.

\subsection{PRODUTOS ALIMENTÍCIOS}

Produtos alimentícios pedem uma atenção especial no seu confinamento, não podendo ser misturados com outros produtos, inclusive 
com outros alimentos, pois cada um possui características diferentes um do outro. Alguns necessitam de refrigeração para manterem-se frescos e com qualidade, como as carnes e alguns produtos derivados do leite.

Segundo PINTO, J \& NEVES, R. (2010), a armazenagem de alimentos deve ser em locais que possuam condições que visam inibir a velocidade de decomposição dos alimentos, sendo que essas condições passam a ser asseguradas por aplicação de temperatura e umidade adequadas a cada tipo específico de alimento. Outro cuidado importante é utilizar sempre o FIFO (First In First Out), de modo a não existir um elevado risco de degradação, da embalagem ou do produto.

Ainda segundo os autores citados no parágrafo anterior, existem princípios básicos de armazenagem que devem ser cumpridos e que são comuns a todos os alimentos, ou seja, princípios como as boas práticas de higiene na área de armazenagem dos alimentos, e utilização de material adequado que em contato direto ou indireto com os alimentos, não proporcionem perigo para a segurança dos mesmos.

\subsection{CADEIA DO FRIO APLICADA NA ALIMENTAÇÃO}

A cadeia de frio surgiu como uma necessidade para a manutenção da qualidade dos produtos exportados. Eles não dependem propriamente da temperatura, mas sim de um controle de umidade para conservação das embalagens. Para isso a temperatura precisa ser controlada para determinar os níveis adequados de umidade ao qual o produto necessita.

Segundo Jorge N. (2013) o processo de oxidação superficial das embalagens metálicas é frequente, depende das condições de umidade relativa e temperatura ambiente e se inicia nas bordas da bobina ou das folhas cortadas.

Se a cadeia do frio receber um aumento de temperatura, independentemente do ponto que ocorrer, as características dos alimentos poderão ser afetadas, sem possibilidade de recuperação. Ou seja, caso o produto esteja deteriorado, o processo de refrigeração não reverte a situação. Para que os alimentos cheguem à etapa de conservação com boa qualidade, é necessário que o transporte seja feito de forma adequada.
Segurança é dotar a área de armazenagem de sistemas que garantam a integridade física da mercadoria armazenada, mão-de-obra, segurança das instalações e equipamentos, e a saúde financeira da empresa, mantendo as equipes de trabalho devidamente treinadas para eventuais emergências (RODRIGUES, 2013)

\subsection{TEMPERATURA E UMIDADE}

A temperatura é uma grandeza física utilizada para medir o grau de agitação ou a energia cinética das moléculas de uma determinada quantidade de matéria. Quanto mais agitadas essas moléculas estiverem, maior será sua temperatura. O aparelho utilizado para fazer medidas de temperatura é o termômetro, que pode ser encontrado em três escalas: Celsius, Kelvin e Fahrenheit.

A menor temperatura a que os corpos podem chegar é chamada Zero absoluto, que corresponde a um ponto onde a agitação molecular é zero, ou seja, as moléculas ficam completamente em repouso. Essa temperatura foi definida no século XIX pelo cientista inglês Willian Thompson, mais conhecido como Lord Kelvin. O zero absoluto tem os seguintes valores: OK - escala Kelvin e $-273,15 \stackrel{\circ}{C}-$ na escala Celsius.

Segundo Guedes (2008), a medição e o controle da temperatura são dois parâmetros muito importantes na plena manutenção e eficácia da cadeia do frio e para a segurança alimentar, no entanto, o parâmetro ou fator tempo também é muito importante para que um produto alimentício mantenha-se seguro. O período de tempo a que um alimento poderá estar sujeito a temperaturas anômalas é decisivo para a segurança dos produtos alimentícios ou gêneros alimentícios refrigerados e/ou ultracongelados.

A umidade do ar diz respeito à quantidade de vapor de água presente na atmosfera, o que caracteriza se o ar é seco ou úmido, e varia de um dia para o outro. A alta quantidade de vapor de água na atmosfera favorece a ocorrência de chuvas. Já com a umidade do ar baixa, é difícil chover.

Quando se fala de umidade relativa, compara-se a umidade real, que é verificada por aparelhos como o higrômetro; e o valor teórico, estimado para aquelas condições. A umidade relativa pode variar de 0\% (ausência de vapor de água no ar) a 100\% (quantidade 
máxima de vapor de água que o ar pode dissolver, indicando que o ar está saturado).

Em regiões onde a umidade relativa do ar se mantém muito baixa por longos períodos, as chuvas são escassas. Isso caracteriza uma região de clima seco.

\subsection{DATALOGGER}

Equipamento utilizado para auxiliar na coleta de dados de outros instrumentos, através da contagem de pulsos eletrônicos, emitidos pelo aparelho ao qual o datalogger foi adaptado para registrar a medição sempre que um evento acontece ou se repete.

Possui uma unidade de memoria para guardar as informações e que pode transmitilas para um computador, notebook ou tablet que esteja conectado com software adequado para essa recepção. Ele gera e analisa os dados, produz gráficos, compara parâmetro com outros aparelhos de mesma função e associa dados de observação continua. Eles podem ser utilizados para aferição de temperatura e umidade em diferentes locais.

\section{DESENVOLVIMENTO DA TEMÁTICA}

O trabalho buscou fundamentar o assunto abordado de forma a representar o cenário atual. Entre elas, a questão do clima predominante em municípios como Cubatão, onde particularidades na temperatura e umidade são observadas nos dados apresentados.

O levantamento histórico de 30 anos da temperatura e índices pluviométricos de Cubatão mostra que os primeiros e últimos trimestres são os mais quentes, úmidos e chuvosos do ano (Gráfico 1). Por este motivo a pesquisa foi realizada entre os dias 16/09/2014 e 24/04/2015.

Gráfico 4 - Mínima, Máxima e Precipitação em Cubatão

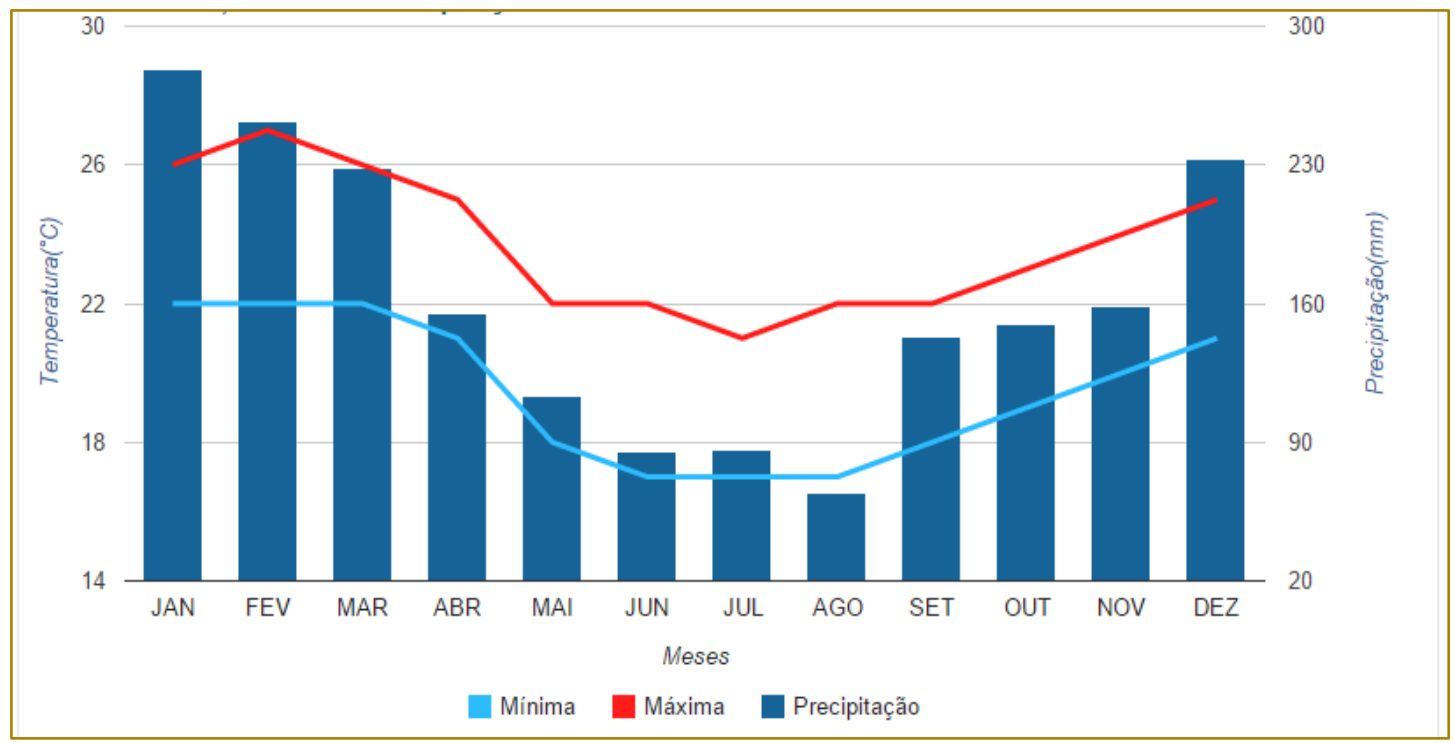

Fonte: INMET/CFS/Interpolação

Para que os resultados obtidos tivessem uma confiabilidade representativa, foram utilizados 9 (nove) equipamentos de monitoramento de temperatura e umidade chamados de Datalogger . Os modelos utilizados são os Turbo Tags H8000 (TBT), de uma empresa especializada em fornecer soluções para a cadeia do frio em diferentes segmentos, sendo os principais o alimentício, produtos farmacêuticos, médicos e produtos químicos. (Figura 2). 
Figura 2 - Imagem de Turbo Tag

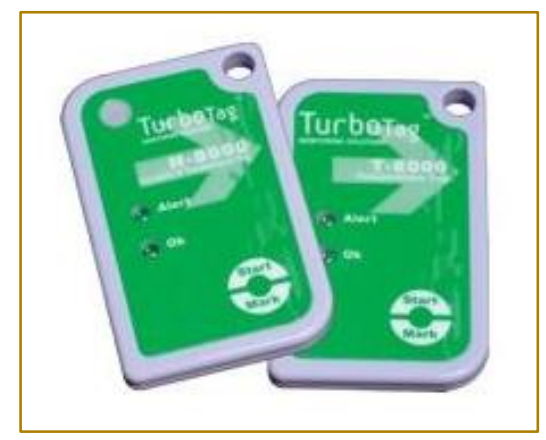

Fonte: Site Mecalux Logismarket

As características abaixo fazem parte do modelo TBT H8000:

- Indicador de alerta - indica se as leituras estão fora dos limites pré-definidos.

- Marcas de inspeção podem ser feitas durante o monitoramento, pressionando o botão "START MARK".

- Botão para iniciar registro com opção de atraso ou início em Data e Hora específicas.

- Alto desempenho a um baixo custo.

- Download Rápido. Leva alguns segundos para baixar os registros e gerar gráficos e relatórios.

- Ótima resolução - 0,1\%RH \& $0,1^{\circ} \mathrm{C} /{ }^{\circ} \mathrm{F}$.

- Alto desempenho a um baixo custo.

- Do tamanho de um cartão de crédito pode ser facilmente enviado pelo correio.

O software é fácil de usar e roda em qualquer computador. Permite ajustar o TBT e baixar os dados para análise. Os dados também podem ser exportados para formatos compatíveis com outros aplicativos, como o Excel.

- Custos de TI inexistentes, fácil integração com os sistemas de dados da empresa.

- Calibrados e certificados gerando resultados precisos e confiáveis.

- Reutilizável

- Substitui o termo higrômetro de maneira eficiente - permite redução de custos de mão de obra, ao mesmo tempo em que aumenta a confiança nos dados coletados.

O monitoramento do armazém REDEX baseou-se em configurar os TBT conforme especificação dos produtos analisados, ou seja, com parâmetros de temperatura de 15 a $25^{\circ} \mathrm{C}$ e umidade de 40 a $60 \%$, com leituras realizadas de hora em hora (Figuras 3 e 4 ). 
Figura 3 - Configuração do parâmetro de umidade relativa

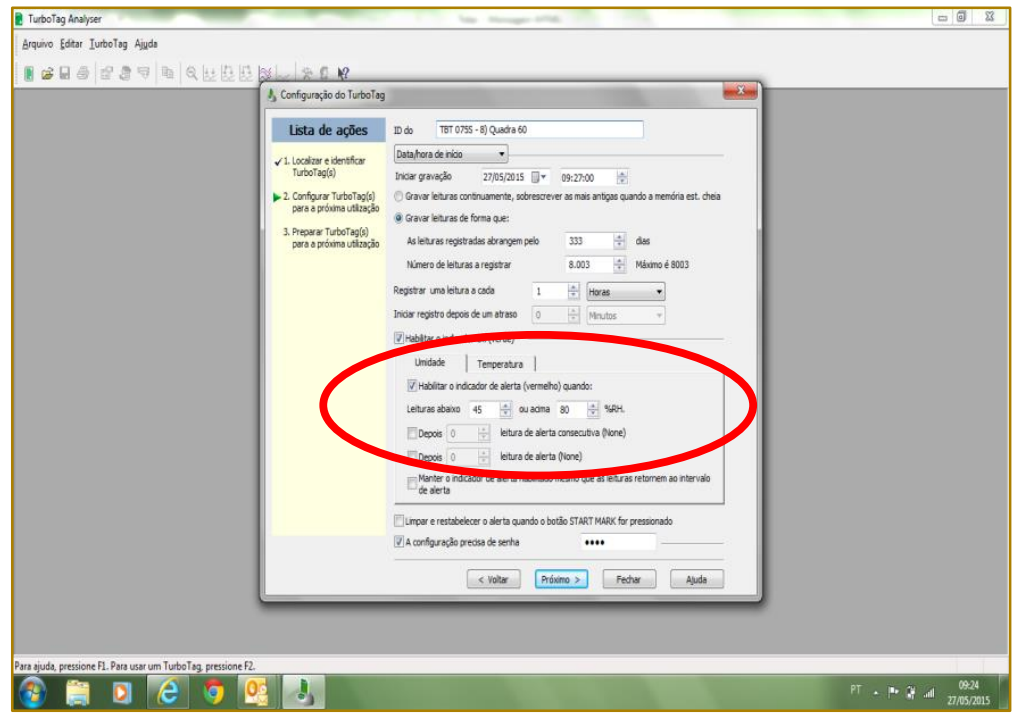

Fonte: Tela do Software Turbo Tag

Figura 4 - Configuração do parâmetro de temperatura

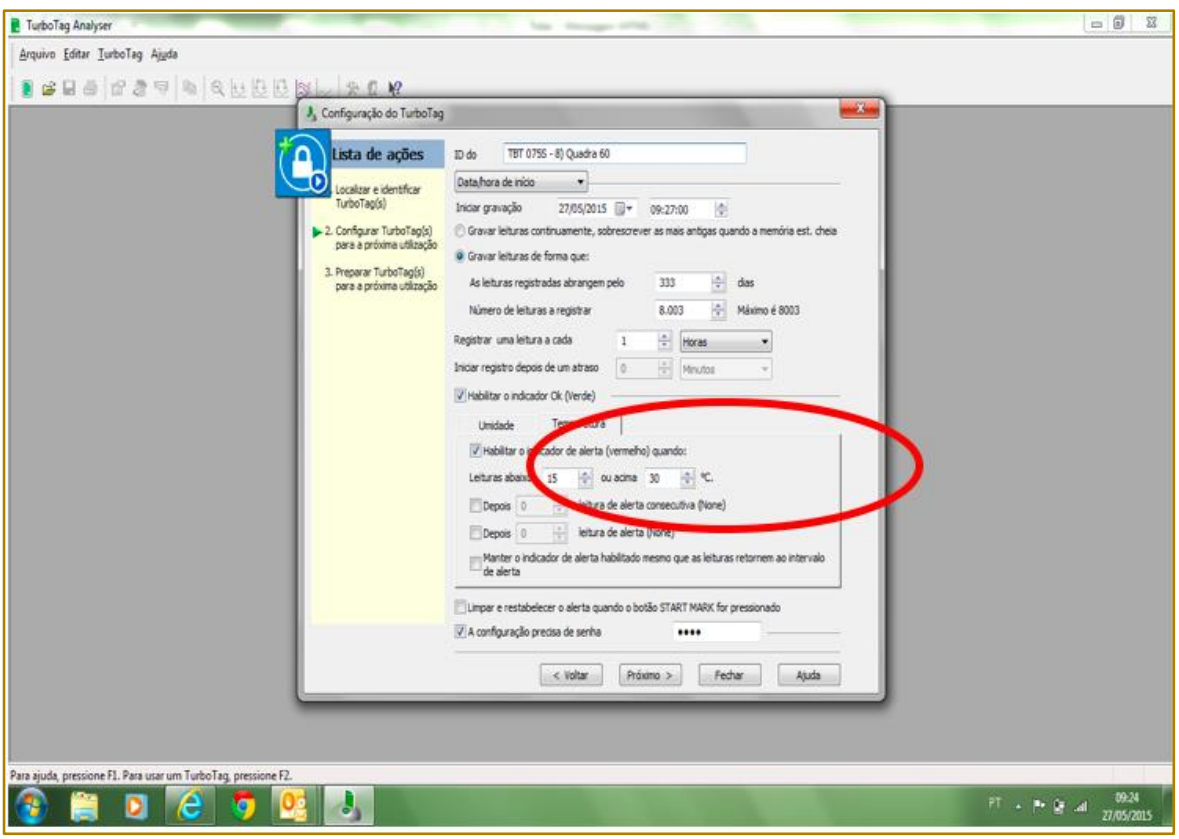

Fonte: Tela do Software Turbo Tag

Os TBT foram acondicionados durante 0 tempo do monitoramento em caixas de acrílico vazadas para manter sua integridade sem comprometer os resultados. (Figura 5). 
Figura 5 - Foto de TBT em ponto de monitoramento

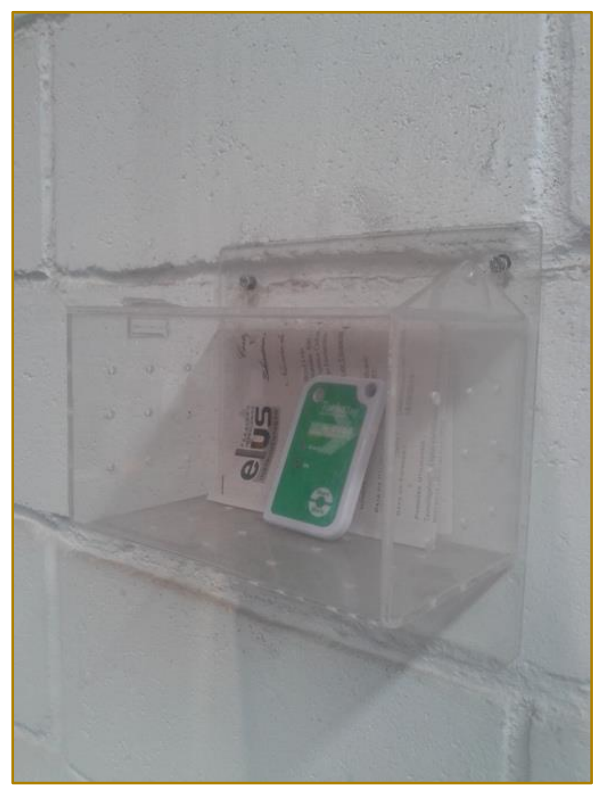

Fonte: Acervo do autor

Todos os TBT foram calibrados, de forma rastreável à Rede Brasileira de Calibração (RBC), em laboratórios devidamente credenciados ao INMETRO (Instituto Nacional de Metrologia Qualidade e Tecnologia), garantindo com que todos os resultados apresentados estivessem dentro dos critérios de aceitação, que no caso foi utilizado para temperatura o de "Erro Máximo + Incerteza" de $1,2^{\circ} \mathrm{C}$; e para umidade o de "Erro Máximo + Incerteza" de $10 \%$.

A localização dos TBT foi decidida de forma estratégica, considerando que os 9 pontos mapeassem a totalidade do armazém. Foram 7 pontos (TBT002E, TBT003E, TBT004E, TBT005E, TBT006E, TBT007E e TBT008E) posicionados a uma altura de 2 metros do piso, representando a grande maioria das cargas armazenadas (blocado) e 2 pontos (TBT001E e TBT009E) posicionados a 10 metros do piso, representando a minoria das cargas armazenadas (porta pallets), onde esta última medição foi de grande importância pois existia a possibilidade da temperatura e umidade serem maiores nestes pontos por estarem mais próximos ao teto do armazém.

Para que as informações fossem disponibilizadas de forma eletrônica, foi utilizada uma base coletora, onde os TBT, um a um, foram acoplados e tiveram seus dados transferidos ao computador.

\section{RESULTADOS E DISCUSSÃO}

Após ter transcorrido o tempo de testes e estudos, que foram de 219 dias, os 9 TBT foram retirados de seus pontos para que os resultados das suas 5277 leituras fossem coletados e analisados de forma independente.

Foi evidenciado que a temperatura média em todos os pontos estudados obteve resultados muito próximos, sendo que mesmo o armazém possuindo uma manta térmica no interior do teto, a média nos 9 pontos estiveram acima dos $25^{\circ} \mathrm{C}$.

Em relação a umidade relativa, temos uma condição diferenciada entre os 9 pontos, chegando até 8,9\% entre a média mínima (TBT001E) e média máxima (TBT005E). O armazém como um todo, tem uma condição de umidade mais acentuada na posição dos TBT005E, TBT006E e TBT007E, que representa o lado direito ao fundo. Foi observado que a posição da construção do imóvel em relação ao sol pode ser um fator que influencia negativamente no acondicionamento de cargas que requerem um cuidado diferenciado em determinados locais do Redex.

\section{CONSIDERAÇÕES FINAIS}

Este trabalho vem de encontro com uma necessidade específica de armazenamento 
de cargas com a finalidade de exportação, onde a qualidade do produto e da embalagem que o protege tem que embarcar íntegros. São poucos os casos em que o exportador tem o cuidado em garantir tais condições, sendo que geralmente o custo deste acondicionamento torna-se mais elevado que o habitual.

Trabalhamos com uma hipótese de melhoria deste processo de armazenagem, utilizando uma área, dentro do armazém já existente, para segregar as cargas que necessitam deste controle de temperatura e principalmente umidade. A proposta trata-se de um vinigalpão com as seguintes especificações:

\section{1 - Cargas Térmicas (sem painéis frigoríficos)}

- Temperatura interna: $24^{\circ} \mathrm{C}+$ ou $-2^{\circ} \mathrm{C}$

- Umidade interna: 50\% + ou - 10\%

- Nesta área haverá a necessidade de utilizar 195 kW ou $170.000 \mathrm{kcal} / \mathrm{h}$ (57 TR's)

- Controle de temperatura e umidade se faz através de comando digital, ou seja, podem-se alterar os valores caso seja necessário.

\section{2 - Equipamentos de climatização e controle de umidade (sem painéis frigoríficos)}

- Quantidade requerida de 3 equipamentos +1 em stand by

- $\quad$ Tipo Spity System

- BBT 200 (Heatcraft) c/ controle de umidade

- Capacidade de 50 kW ou 42.000 $\mathrm{kcal} / \mathrm{h}$ (14 TR's)

- Carga requerida/consumo médio: 16 kW / 11,5 kWh

- Tensão disponível: 220/380/440 Volts.

- Valor estimado do equipamento de $\mathrm{R} \$ 75.000,00$ por unidade (sem instalação).

- Instalação com valor estimado de $\mathrm{R} \$ 50.000,00$

- Valor considerado para equipamentos de $R \$ 350.000,00$

- Sistema de exaustão mecânica (dutos, grelhas, difusores, dumpers corta fogo).

- Ventilador (utilizando a própria maquina ) e exaustor se necessário pelo calculo das necessidades do Corpo de Bombeiros.

- Valor estimado, sem conhecimento dos itens, de $\mathrm{R} \$ 200.000,00$

- Valor total do aproximado do investimento de $R \$ 550.000,00$ (quinhentos e cinquenta mil reais).

Nota: Para os valores dos equipamentos temos orçamento, entretanto os demais orçamentos são baseados em valores apresentados na internet e estimativas relativas a quantidade de trabalho das montagens

\section{3 - Prazos:}

- Equipamentos: 15 dias depois do pedido colocado (Heatcraft);

- 45 dias (Termoprol)

- Lona: Não conseguimos a informação;

- Portas: 25 dias depois do pedido colocado;

- Para a execução dos trabalhos pode ser feito cronograma a partir da data da colocação dos pedidos, como exemplo:

Fazendo-se a compra dos itens na mesma época inicia-se a montagem das lonas e quando prontos instala-se os equipamentos, portas e cortina de ar. A sequencia de montagem é bem favorável ao trabalho.

Após colocação dos pedidos precisará de aproximadamente 45 dias para iniciar 0 funcionamento.

Nota: Os valores referentes ao lonado, portas, estruturas não estão inclusos nesta estimativa, bem como necessidade de Inter travamentos com o sistema de incêndio existente.

\section{4 - Custos com energia elétrica:}

- 4 equipamentos em funcionamento: $16 \mathrm{kWh} \times 4=64 \mathrm{kWh}$

- Consumo de 64 kWh x 24 horas/dia $\times$ 30 dias/mês x 0,75 (fator de funcionamento) - Consumo (mês) de 34.560 kWh/mês.

- Custo mensal com energia: 34.560 $\mathrm{kWh} / \mathrm{mês} \quad \mathrm{x} \quad \mathrm{R} \$ 0,3276 \quad \mathrm{kWh}=$ $\mathrm{R} \$ 11.321,85 /$ mês (valor estimado).

A localização ideal deste vinigalpão, segundo nossos estudos com os TBT, seria o mais próximo possível dos TBT001E, TBT002E e TBT003E, ou seja, no lado esquerdo do armazém, próximo as docas. Desta forma estaríamos localizando o acondicionamento 
destas cargas na região mais favorável no ponto de vista de temperatura e umidade, porém, devido à disposição da construção e cumprindo as normas do Corpo de Bombeiros, o local proposto limitou-se no centro do armazém.

O Local destinado a este tipo de carga deverão ter sua temperatura e umidade, além de monitorada (TBT010E, TBT011E, TBT012E e TBT013E), controlada por equipamentos específicos para manter e garantir estas condições para que a qualidade do produto armazenado seja mantida.

A pesquisa se baseou em dados reais, coletados em operações reais, onde as cargas de bens de consumo alimentícias sofrem problemas de qualidade em processos de exportação. Não podemos

\section{REFERÊNCIAS}

[1]. BRASIL. Instrução Normativa da Secretaria da Receita Federal, №114, de 31 de dezembro de 2001. Dispõe sobre a fiscalização aduaneira em Recinto Especial para Despacho Aduaneiro de Exportação (Redex). Publicada no DOU de 04/01/2002, seção, pág. 25.

[2]. GUEDES, R. Manutenção da cadeia de frio nos produtos ultracongelados. Segurança e qualidade alimentar - Segurança na logística, p. 54 2008. http://www.infoqualidade.net/SEQUALI/PDFSEQUALI-05/Page\%2054.pdf . Acesso em: 20 Mai 2015

[3]. HONG, Yuh C. Gestão de estoques na cadeia de logística integrada: supply chain. 1a ed. São Paulo: Atlas, 1999.

[4]. JORGE, N. Embalagens para alimentos São Paulo: Cultura Acadêmica: Universidade Estadual Paulista, 2013. Disponível em: http://www.santoandre.sp.gov.br/pesquisa/ebooks/ 360234.PDF. Acesso em 31 Mar.2015. alterar o clima no município de Cubatão, porém podemos modificar uma área determinada para atender uma demanda específica de produtos.

A sugestão apresentada abrange empresas que tem o mesmo perfil apresentado, e que podem utilizar este estudo como parte de seus processos relacionados ao comércio exterior. Muitos exportadores não têm o conhecimento que suas cargas podem apresentar estes problemas relacionados a qualidade. Não é só um problema de aparência da carga ou da embalagem, mas pode chegar ao ponto de degradação do produto que poderá acarretar a perca de mercado, exposição negativa da marca, e um sério problema de saúde pública, tanto no Brasil quanto nos países de destino.

[5]. MARTINEZ, E. Os caminhos já estão prontos, só falta usá-los. São Paulo, 08 ago.2010. Disponível em: http://ogerente.com.br/rede/logistica/exportacaode-mercadorias. Acesso em 31 Mar.2015.

[6]. MOURA, R, A. Sistema e Técnicas de Movimentação e Armazenagem de Materiais, Volume1, São Paulo: IMAM, 2005

[7]. PINTO, J., \& NEVES, R. Análise de riscos no processamento alimentar. Porto: Publindústria, Edições técnicas, 2010.

[8]. ROCHA, P. C. Logística e Aduana. São Paulo: Aduaneiras, 2013.

[9]. RODRIGUES, P. R. A. Gestão estratégica da armazenagem. São Paulo: Aduaneiras, 2013.

[10]. YIN, R. K. Estudo de caso: Planejamento e Métodos. Porto Alegre, 5a Edição - Bookman Editora, 2015 


\section{Gapítulo 13}

\section{QUALIDADE DE VIDA NO TRABALHO (QVT) COMO DIFERENCIAL NA GESTÃO ESTRATÉGICA DE UMA INSTITUIÇÃO FEDERAL DE ENSINO: ANÁLISE DOS DOCUMENTOS INSTITUCIONAIS DO IFAM}

\section{Wadna Kimberlly da Silva Alves}

\section{Henrique Menezes Nogueira}

Geisy Anny Venâncio

Resumo: Este artigo aborda a importância que o Instituto Federal de Educação, Ciência e Tecnologia do Amazonas (IFAM) emprega em relação a gestão estratégica de pessoas, a fim de descrever as ações do Instituto voltadas para seus servidores, principalmente em relação a Qualidade de Vida no Trabalho (QVT). A pesquisa se desenvolveu a partir de uma análise documental e bibliográfica, tendo como foco a análise de conteúdo, caracterizando a pesquisa como sendo de natureza aplicada, exploratória, com caráter qualitativo. Os principais resultados deste trabalho apontam que o IFAM possui preocupação com o seu capital intelectual e aplica ações voltadas para a QVT dos servidores. Contudo, ainda não há como afirmar se essas ações trouxeram benefícios aos colaboradores, para isso, é necessário investigar as consequências de tais práticas em pesquisas futuras.

Palavras-chave: Gestão Estratégica. Pessoas. Qualidade de Vida no Trabalho. 


\section{INTRODUÇÃO}

A gestão estratégica de pessoas tem originado interesses recorrentes e desafiadores nas organizações. Isso é a consequência de uma crescente preocupação quanto ao bem-estar das pessoas no ambiente de trabalho, além da valorização e satisfação do indivíduo como fator de competitividade organizacional. Dentre as possibilidades de estudos na gestão estratégica de pessoas, a Qualidade de Vida no Trabalho (QVT) e a satisfação profissional encontram-se interligadas quanto às relações do indivíduo com o ambiente organizacional, sendo consideradas elementos que interligam os trabalhadores à organização.

Oliveira e Limongi-França (2005) apresentam a gestão de pessoas como papel fundamental em ambientes organizacionais competitivos, pois conduz os gestores a acompanhar e estabelecer práticas de gerenciamento das instituições, de modo que propicie a realização dos objetivos da empresa através de seus colaboradores. Diante deste contexto, a problemática que norteia esse trabalho é: qual a importância da Qualidade de Vida no Trabalho na gestão estratégica organizacional do Instituto Federal de Educação, Ciência e Tecnologia do Amazonas?

Neste artigo, tem-se como objetivo geral saber se os servidores e a QVT são considerados importante pela gestão estratégica do IFAM. Como objetivos específicos, o artigo irá identificar por meio da análise do Plano de Desenvolvimento Institucional 2014-2018 se a instituição objeto de estudo contempla uma gestão estratégica voltada as pessoas, como também apontar e descrever as ações de QVT dispostas nos documentos institucionais. Os métodos utilizados foram a pesquisa documental, com embasamento teórico através de uma pesquisa bibliográfica, tendo como foco a análise de conteúdo, sendo possível caracterizar a pesquisa como sendo de natureza aplicada, exploratória, com caráter qualitativo.

Salientamos a relevância do estudo de caráter contribuitivo cumulativo, de forma a acrescentar conhecimentos científico para estudos sobre o tema abordado. O presente artigo está estruturado da seguinte forma: introdução, onde é apresentado o tema, bem como a problemática de pesquisa; embasamento teórico, explanando sobre o planejamento estratégico de pessoas e qualidade de vida no trabalho; materiais e métodos, onde é exposta a metodologia utilizada para o desenvolvimento da pesquisa; considerações finais e referências bibliográficas utilizadas.

\section{EMBASAMENTO TEÓRICO}

\subsection{PLANEJAMENTO ESTRATÉGICO DE PESSOAS}

As constantes mudanças do ambiente externo pressionaram as organizações a tomarem importantes decisões. Diante dessa realidade, é cada vez mais necessária a adoção de planos e estratégias que direcionem qual o rumo a empresa deve seguir.

O planejamento estratégico é um processo gerencial de elaboração de objetivos e estratégias utilizadas para definir a direção que a empresa deve seguir, levando em consideração a relação da mesma com o ambiente interno e externo. O processo de planejamento estratégico é quem proporciona sustentação metodológica para estabelecer a melhor direção a ser seguida pela empresa, visando otimizar o grau de interação com os ambientes externo e interno, atuando de forma inovadora e diferenciada, sendo capaz de influenciar toda a empresa (ASSUNÇÃO, 2016).

Uma opção para promover uma gestão organizacional eficaz é a utilização de modelos de gestão. Muitas destas ferramentas têm como principal objetivo direcionar as ações que a empresa deve seguir. Um dos modelos de gestão estratégica mais conhecidos é o Balanced Scorecard (BSC). Tal modelo conta com um conjunto de indicadores considerados essenciais para gestão estratégia. São divididos em indicadores financeiros, indicadores relacionados aos processos internos, ao aprendizado e crescimento e aos clientes (KAPLAN; NORTON, 1997) Esta ferramenta de gestão em conjunto com outras estratégias podem ser um diferencial de competitividade e qualidade.

O capital humano constitui o princípio essencial das organizações, são as pessoas que conferem vitalidade às atividades e processos, inovam, criam, recriam contextos e situações que podem levar ao sucesso da organização (XAVIER, 2011). No entanto, conduzir pessoas numa organização requer 
esforços e estratégias, que devem estar sempre alinhados com a missão, visão, valores e objetivos da empresa, ou seja, a gestão de pessoas deve ser estratégica e fazer parte do planejamento das organizações.

Gestão Estratégica de Pessoas é toda e qualquer mobilização, orientação, direcionamento e administração do fator humano (MASCARENHAS, 2008). Com a globalização, as empresas incorporaram uma visão holística e perceberam a necessidade de uma maior valorização do seu capital intelectual. Dessa forma, a gestão estratégica de pessoas passa a ser um mecanismo gerencial eficaz e que gera muitas mudanças no cenário interno das organizações (SOUZA, 2017), sendo de grande importância para qualquer entidade, de caráter privado ou público.

Nesta perspectiva, as instituições de ensino superior (IES) também necessitam de um estudo estratégico, que as norteiem a uma direção de sucesso. $O$ documento estruturante do processo de planejamento nas instituições de ensino superior é o Plano de Desenvolvimento Institucional (PDI) (FRANCISCO et al., 2012). É por meio deste documento que as instituições de ensino podem nortear suas práticas e avaliações. Para Francisco et al. (2012) o PDI é um documento dinâmico e flexível, que determina o posicionamento concreto da instituição de educação.

O PDI foi criado pelo Ministério da Educação e é regido pelo Decreto № 5773/06, que dispõe sobre o exercício das funções de regulação, supervisão e avaliação de instituições de educação superior e cursos superiores de graduação e sequenciais no sistema federal de ensino. De acordo com a Lei № 10861/14, a qual institui o Sistema Nacional de Avaliação Superior (SINAES) é obrigatório que as IES desenvolvam e comprovem a existência de seus PDI's.

Cada organização estabelece em seu planejamento a maneira pela qual irá gerir seus recursos, no entanto o sucesso organizacional depende significativamente da importância que é dada às pessoas. É notório que as empresas que investem em seu capital intelectual se desenvolvem de forma saudável, proporcionam melhorias do clima organizacional, aumentam a Qualidade de Vida dos seus colaboradores e a satisfação profissional.

\subsection{QUALIDADE DE VIDA NO TRABALHO}

A Qualidade de Vida no Trabalho tem sido um dos anseios dos indivíduos desde seu surgimento, e por muitas vezes é evidenciada por definições divergentes, porém frequentemente envolvendo a questão de satisfação (RODRIGUES, 2007).

De acordo com Alves (2011), a QVT é vista como um objeto de motivação de indivíduos, tendo como intuito a garantia de boa produtividade para as instituições. As organizações devem se comprometer com ações que levem bem-estar, estabilidade no ambiente de trabalho, reconhecimento e valorização dos colaboradores, resultando em uma maior produtividade.

A QVT considera o grau de satisfação dos indivíduos com o trabalho, bem como remunerações e quão motivados são. Isto é capaz de colaborar com a melhoria do bemestar dos trabalhadores dentro de suas ocupações no ambiente organizacional. (AZIZ et al., 2011). Na medida em que os indivíduos trabalham satisfeitos e motivados, resulta-se uma maior probabilidade de esses indivíduos se dedicarem mais, trabalharem melhor e, consequentemente, conseguirem um melhor desempenho nas suas atividades.

Nesse contexto, o conhecimento sobre QVT é designado através de oito indicadores, os quais buscam a averiguação do índice de qualidade no ambiente organizacional, conforme aferido por Brighenti, Silva e Fernandes (2002, p. 3), com base no modelo sugerido por Walton (1973). Para esta pesquisa, utilizou-se o referido modelo, o qual foi construído a partir de uma análise de experiências dos trabalhadores atuantes dentro de uma organização, sendo estabelecidos os indicadores detalhados na Figura 3.

A crescente preocupação com o desenvolvimento de políticas de gestão de pessoas mostra-se primordial, pois é vista atualmente como uma das estratégias de crescimento das instituições. De acordo com Oliveira e Limaghi-França (2005), os indivíduos são objeto principal de trabalho quando se fala da Gestão de Pessoas. A missão de administrar pessoas adquire espaço e valor, em razão de alcance de metas e objetivos.

O setor público consistindo unicamente na prestação de serviços, o cuidado para com seu pessoal torna-se primordial para 0 
aperfeiçoamento dos serviços fornecidos por esse setor (GUERREIRO, 2013). As instituições públicas demonstram uma atenção voltada à melhoria da QVT, pois de acordo com Bezerra (2007), a falta de motivação dos indivíduos do serviço público provoca um serviço precário e, por isso, tornou-se uma das principais preocupações das organizações.

Segundo Frossard (2008), a gestão de pessoas que dispõe de uma política de QVT tem estado cada vez mais destacada, visto que através dela busca-se o bem-estar do indivíduo juntamente à organização, levando benefícios e melhorias na qualidade e produtividade de ambos. Com isso, a QVT se expressa como um fator fundamental para a integração dos objetivos individuais dos colaboradores e os objetivos organizacionais, causando maior eficiência e eficácia quanto a produtividade dos trabalhadores.

\section{MATERIAIS E METÓDOS}

O presente estudo tem natureza aplicada e se classifica como pesquisa exploratória e descritiva, pois visa o aperfeiçoamento das ideias sobre Gestão Estratégica de Pessoas, sua relação com a QVT como também a descrição e análise dos problemas referentes ao tema (GIL, 2008). Quanto a abordagem, o estudo tem caráter qualitativo, pois segundo Minayo (2011) na pesquisa qualitativa lida-se com informações que não podem ser quantificadas, pois essas fazem parte de um processo cujo principal foco são os significados, motivos, aspirações etc.

Em relação aos procedimentos técnicos adotados, a pesquisa é predominantemente documental, no entanto, o artigo também se baseia no levantamento teórico dos temas abordados, por meio da pesquisa bibliográfica. A primeira técnica de pesquisa utilizada trata-se da observação de documentos legais do IFAM. Os documentos analisados foram: Plano de Desenvolvimento Institucional 2014-2018; Manual do Servidor 2015; Minuta do Programa de Capacitação e Qualificação do IFAM; Planos de Carreira Docente e Técnico Administrativo.

Os dois procedimentos adotados têm como foco a análise e interpretação dos dados coletados por meio da Análise de Conteúdo que, segundo Bardin (2002, p. 47), visa "[...] obter [...] indicadores (quantitativos ou não) que permitam a inferência de conhecimentos relativos às condições de produção/recepção [...] [do conteúdo de determinadas mensagens]".

Durante a pesquisa documental, buscou-se verificar se na Instituição há uma preocupação com o capital intelectual e se seu plano estratégico possui uma gestão com diretrizes voltadas especificamente para as pessoas. Para isso, foi considerado os objetivos estratégicos e metas presentes no PDI 2014-2018. Procurou-se, também por meio da análise dos documentos disponíveis, apontar e descrever as ações voltadas para QVT dos servidores, caso houvesse. As ações foram divididas seguindo o conceito de Walton, que é considerado pela literatura um dos modelos que mais contempla os processos de diagnóstico da QVT.

Para a pesquisa bibliográfica, procurou-se facilitar o tratamento dos dados por meio de uma triagem do assunto. Esta estratégia teve como objetivo melhorar as análises das informações e separá-las em partes, organizadas como um roteiro para o levantamento bibliográfico, abordando as contribuições de outros autores sobre a gestão estratégica organizacional, gestão estratégica de pessoas e QVT.

\section{RESULTADOS E DISCUSSÕES}

Os resultados deste trabalho contemplam informações referentes à gestão estratégia de pessoas do IFAM. Na primeira parte, foram descritas as informações do Instituto, como os setores responsáveis pela gestão dos servidores. Em seguida, as análises foram focadas no documento de planejamento da instituição, o PDI. Nesta parte, foram levantadas informações de como o planejamento estratégico se porta em relação aos seus recursos humanos. Por último, foram descritas as ações de QVT adotadas pelo IFAM, com base nos documentos institucionais. Estas ações foram analisadas, separadas e descritas de acordo com as dimensões e indicadores descritos por Walton (1973).

\subsection{INSTITUTO FEDERAL DE EDUCAÇÃO, CIÊNCIA E TECNOLOGIA DO AMAZONAS}

O Instituto Federal de Educação, Ciência e Tecnologia do Amazonas foi fundado através da Lei № 11.892/2008, de acordo com os termos constantes no Art. $5^{\circ}$, inciso IV. A 
Reitoria da Instituição está situada no município de Manaus e conta com cinco PróReitorias. Vinculada a Pró-Reitoria de Administração está a Diretoria de Gestão de Pessoas, que dispõe de 3 coordenações: administração de pessoas; desenvolvimento de pessoas; benefícios e qualidade de vida. Além desses setores, O IFAM possui departamentos de atenção à saúde, que conta com médicos, enfermeiros, nutricionista, psicólogos e profissionais capacitado na área de odontologia.

\subsection{PDI E GESTÃO ESTRATÉGICA DE PESSOAS}

O IFAM, em seu PDI 2014-2018, mostra uma preocupação com a gestão de pessoas, conforme é possível observar na Figura 1. Estes objetivos e metas são voltados especificamente para a integração, desenvolvimento, qualidade de vida e capacitação dos servidores.

Quadro 1 - Objetivos estratégicos voltados para gestão de pessoas

\begin{tabular}{|c|c|}
\hline OBJETIVOS ESTRATÉGICOS & METAS \\
\hline $\begin{array}{l}\text { Promover a interação, desenvolvimento e qualidade } \\
\text { de vida dos servidores }\end{array}$ & $\begin{array}{c}\text { Realizar ações para o desenvolvimento, interação } \\
\text { dos servidores e comunicação; } \\
\text { Implantar / Desenvolver programas de Qualidade e } \\
\text { Vida; } \\
\text { Realizar exames periódicos com os servidores; } \\
\text { Promover atividades desportivas, culturais e } \\
\text { educativas. }\end{array}$ \\
\hline Elaborar o plano de capacitação dos servidores & Capacitar servidores \\
\hline
\end{tabular}

Fonte: Adaptado de IFAM (2014, p. 52-54. PDI IFAM 2014-2018).

O IFAM dispõe em seu PDI 2014-2018 de 2 objetivos estratégicos subdivididos em 5 metas voltadas para a administração dos recursos humanos. Esses objetivos estão relacionados de forma direta ou indireta com a QVT. O que demonstra a preocupação que a instituição de ensino tem em relação ao seu capital intelectual. Além de incluir em seu planejamento objetivos e metas voltados para gestão de pessoas, a instituição também utiliza modelos de gestão estratégica. 0 principal modelo seguido é o BSC (Figura 2). Seu objetivo principal é mensurar o progresso da organização em relação as suas metas. 
Quadro 2 - Perspectiva do Balanced Scorecard - (PDI IFAM 2014-2018)

\begin{tabular}{|c|c|c|c|c|c|}
\hline \multirow{2}{*}{ INDICADORES } & \multicolumn{5}{|c|}{ METAS } \\
\hline & 2014 & 2015 & 2016 & 2017 & 2018 \\
\hline Docentes e/ou pesquisadores enviados ao exterior & 5 & 8 & 10 & 15 & 20 \\
\hline Docentes e/ou pesquisadores recebidos do exterior & 2 & 4 & 5 & 8 & 10 \\
\hline Técnicos administrativos enviados ao exterior & 2 & 3 & 5 & 7 & 8 \\
\hline Técnicos administrativos recebidos do exterior & 3 & 4 & 5 & 6 & 8 \\
\hline Servidores qualificados em curso de nível superior & 10 & 5 & 4 & 8 & 15 \\
\hline $\begin{array}{l}\text { Participação de servidores em congressos e seminários de sua } \\
\text { área de atuação }\end{array}$ & 80 & 170 & 175 & 180 & 200 \\
\hline Servidores capacitados e/ou aperfeiçoados & 110 & 120 & 140 & 266 & 260 \\
\hline Realização de Exames Médicos & 100 & 200 & 250 & 270 & 300 \\
\hline Implantação do Programa Qualidade de Vida nos Campi & 3 & 4 & 5 & 3 & - \\
\hline Realização de Atividades Desportivas e Educativas & 33 & 34 & 38 & 38 & 41 \\
\hline $\begin{array}{l}\text { Quantidade de qualificações para Técnicos Administrativos em } \\
\text { nível de Especialização }\end{array}$ & 40 & 50 & 60 & 70 & 75 \\
\hline $\begin{array}{l}\text { Quantidade de qualificações para Técnicos Administrativos em } \\
\text { nível de Mestrado/Doutorado }\end{array}$ & 5 & 8 & 10 & 10 & 20 \\
\hline $\begin{array}{l}\text { Quantidade de qualificações para professores em nível de } \\
\text { Mestrado }\end{array}$ & 30 & 40 & 55 & 60 & 70 \\
\hline Quantidade de Professores com Doutorado & 5 & 6 & 7 & 8 & 10 \\
\hline Quantidade de Professores com Pós-Doutorado & 3 & 4 & 5 & 5 & 6 \\
\hline Admissão de Servidores & 114 & 90 & 80 & 50 & - \\
\hline
\end{tabular}

Fonte: Adaptado de IFAM (2014, p. 73. PDI IFAM 2014-2018).

Por meio deste modelo, o IFAM acompanha seus indicadores e metas estabelecidos em seu planejamento. A perspectiva em análise é voltada para a estratégia de pessoas e conta com indicadores voltados para qualidade de vida no trabalho. As informações apresentadas na figura anterior também evidenciam que o IFAM considera as pessoas como parte essencial da organização e que sua gestão faz parte de um planejamento estruturado.

Em um dos tópicos do PDI 2014 - 2018 o assunto tratado é a organização e gestão do pessoal. A partir do texto é possível extrair apontamentos que comprovam a importância da gestão estratégica de pessoas.

A Carta de Brasília da Gestão Pública, [...], registra as principais preocupações e diretrizes que devem orientar as estratégias e as ações em prol da construção de um pacto para melhorar o [...] [PDI] 2014-2018 [...] um dos tópicos que merece destaque é a gestão de pessoas, por ser este um elemento estruturante da gestão. Uma vez que a Carta de Brasília está norteando as novas políticas que buscam a excelência gerencial, faz-se necessário garantir neste PDI que as estratégias e políticas na área de organização e gestão de pessoal do [...] [IFAM] sejam convergentes com essa nova perspectiva. [...] pretende-se criar condições para o crescimento pessoal e profissional, proporcionando oportunidade de conhecimento, desenvolvimento de habilidades e de competências [...]. (IFAM, 2014, p.139-140).

A partir da análise realizada no PDI do Instituto, percebe-se que o objeto de estudo deste trabalho, contempla uma gestão estratégica voltada às pessoas e que estes ativos são de grande importância para a organização. Desta forma, na medida que ações voltadas para os servidores são implantadas, há uma maior probabilidade de 
alto desempenho, acarretando um maior índice de desenvolvimento, tornando mais provável o alcance da visão institucional.

\section{AÇÕESS DE QVT ADOTADAS PELO IFAM}

O estudo de Qualidade de Vida no Trabalho é ponderado por oito indicadores de qualidade, conforme o modelo sugerido por Walton (1973), o qual se utiliza da vivência dos indivíduos dentro da organização. Com o objetivo de estabelecer o índice de QVT, são levadas em consideração as dimensões descritas na Figura 3.

Quadro 3 - Indicadores de Walton e Ações de QVT previstas nos documentos institucionais do IFAM.

\begin{tabular}{|c|c|c|}
\hline Dimensões & Indicadores & Ações IFAM \\
\hline $\begin{array}{l}\text { Compensação justa e } \\
\text { adequada }\end{array}$ & Salário e remunerações & $\begin{array}{l}\text { 1. Auxílios; } \\
\text { 2. Remuneração de acordo com o } \\
\text { enquadramento em planos regidos por leis. }\end{array}$ \\
\hline Condições de trabalho & $\begin{array}{l}\text { Jornada de trabalho; } \\
\text { Promoção à saúde e } \\
\text { segurança. }\end{array}$ & $\begin{array}{l}\text { 1. Licença para tratamento da saúde própria e de } \\
\text { terceiros; } \\
\text { 2. Realização de exames periódicos; }\end{array}$ \\
\hline $\begin{array}{l}\text { Condições para o } \\
\text { crescimento pessoal e } \\
\text { profissional }\end{array}$ & $\begin{array}{l}\text { Possibilidade de Carreira; } \\
\text { Crescimento pessoal; } \\
\text { Segurança no emprego. }\end{array}$ & $\begin{array}{l}\text { 1. Sistema de avaliação de desempenho dos } \\
\text { servidores; } \\
\text { 2. Projeto de capacitação de servidores; } \\
\text { 3. Enquadramento dos docentes na Carreira de } \\
\text { Magistério Ensino Básico } \\
\text { 4. Enquadramento dos servidores técnico- } \\
\text { administrativos no Plano de Carreira dos } \\
\text { Técnicos-Administrativos em Educação. }\end{array}$ \\
\hline $\begin{array}{l}\text { Uso e } \\
\text { desenvolvimento de } \\
\text { capacidades }\end{array}$ & $\begin{array}{l}\text { Autonomia; Significado e } \\
\text { Identificação de tarefa; } \\
\text { Variabilidade de habilidade e } \\
\text { feedback. }\end{array}$ & $\begin{array}{l}\text { 1. Banco de talentos; } \\
\text { 2. Adequação do perfil dos servidores com suas } \\
\text { atividades de trabalho; } \\
\text { 3. Uso do Sistema de Gestão por Competências } \\
\text { para os servidores. }\end{array}$ \\
\hline Integração social & $\begin{array}{l}\text { Igualdade de oportunidades; } \\
\text { Relacionamento; Senso } \\
\text { comunitário. }\end{array}$ & $\begin{array}{l}\text { 1. Integração de servidores aposentados às } \\
\text { atividades do instituto. } \\
\text { 2. Política de desenvolvimento, interação dos } \\
\text { servidores e comunicação. } \\
\text { 3. Programa de acolhimento de novos servidores. }\end{array}$ \\
\hline Constitucionalismo & $\begin{array}{l}\text { Respeito às leis e direitos } \\
\text { trabalhistas; privacidade } \\
\text { pessoal; Liberdade de } \\
\text { expressão; normas e rotinas. }\end{array}$ & $\begin{array}{l}\text { 1. Orientação do servidor sobre a legislação e } \\
\text { normas vigentes; } \\
\text { 2. Instrução dos servidores sobre os benefícios e } \\
\text { suas concessões; }\end{array}$ \\
\hline $\begin{array}{l}\text { O trabalho e o espaço } \\
\text { total da vida }\end{array}$ & $\begin{array}{l}\text { Papel balanceado do } \\
\text { trabalho. }\end{array}$ & $\begin{array}{l}\text { 1. Promoção de atividades desportivas, culturais } \\
\text { e educativas para os servidores. }\end{array}$ \\
\hline $\begin{array}{l}\text { Relevância Social da } \\
\text { vida no trabalho. }\end{array}$ & $\begin{array}{l}\text { Imagem da empresa; } \\
\text { Responsabilidade social pelos } \\
\text { empregados; } \\
\text { Responsabilidade pelos } \\
\text { produtos e serviços. }\end{array}$ & $\begin{array}{l}\text { 1. Diagnóstico do clima organizacional } \\
\text { 2. Orientação sobre a ética profissional do } \\
\text { servidor, no tratamento com as pessoas e com o } \\
\text { patrimônio público. }\end{array}$ \\
\hline
\end{tabular}

Fonte: Elaboração própria (2018). Com base em Brighenti, Silva e Fernandes (2002, p. 03). 
Os procedimentos demonstrados acima evidenciam a correlação de ações de QVT com as práticas estratégicas de Gestão de Pessoas do IFAM, conforme a instituição mantém uma visão metódica do bem-estar dos servidores quanto ao ambiente organizacional. Para tanto, pode-se observar a corroboração de realizações de gestão acerca da QVT.

A integração de QVT com a gestão de pessoas se mostra fundamental no planejamento das organizações ao traçar estratégias de melhorias, a fim de fornecer condições para o bem-estar os colaboradores. Entende-se que, com esses elementos, os servidores venham a ser mais produtivos e proativos, de modo que sejam gerados benefícios quanto ao desempenho de serviços prestados pela instituição. Com isto, a atenção passa a estar mais voltada para o bem-estar e a qualidade de vida dos trabalhadores no ambiente organizacional.

\section{CONSIDERAÇÕES FINAIS}

As pessoas são partes essenciais em qualquer organização, por esse motivo são consideradas um ativo de grande importância. Para alcançar o sucesso, as empresas necessitam traçar estratégias voltadas para os recursos humanos. Desta forma, a gestão estratégica das pessoas deve estar alinhada com os objetivos estratégicos da organização e fazer parte de seu planejamento. Ações voltadas para a QVT dos servidores tendem a fazer parte do planejamento das organizações que almejam um desenvolvimento saudável.

Conforme mencionado na literatura, a QVT é um dos aspectos associados a motivação e satisfação profissional e, quando alcançado, gera bons resultados.

O objetivo principal deste trabalho foi identificar se os servidores e QVT são considerados importantes pela gestão estratégica do IFAM. Diante das análises realizadas em documentos institucionais, foi

\section{REFERÊNCIAS}

[1]. ALVES, E. F. Programas e ações em qualidade de vida no trabalho: possibilidades e limites das organizações. Revista Eletrônica Fafit/facic. Itararé, v. 2, n. 1, p.14-25, jan/jun. 2011. possível perceber que há uma preocupação com os servidores e que a gestão estratégica de pessoas faz parte do planejamento organizacional. A instituição dispõe de setores específicos para a gestão do pessoal. Estes setores são os responsáveis por executar os objetivos e metas traçados e expressos no PDI. Além disto, por meio da pesquisa documental pôde-se apontar que o IFAM apresenta ações voltadas para a qualidade vida de seus servidores. Em suma, pode-se enfatizar que existe uma correlação entre as ações de QVT com as práticas estratégicas de Gestão de Pessoas do IFAM.

Para atingir os objetivos deste trabalho, utilizou-se, sobretudo, a pesquisa documental. O IFAM divulga suas informações de forma transparente, as mesmas estão disponíveis no site institucional e fornecem muitas informações que evidenciam sua preocupação para com os seus servidores. No entanto, não foi possível comprovar se as práticas voltadas para QVT estão gerando satisfação profissional. Para isso, novas pesquisas devem ser realizadas com o intuito de investigar as consequências dessas ações. Sugere-se, portanto, a continuidade das análises tendo como referência os PDI's atualizados, bem como um estudo mais aprofundado sobre as percepções dos servidores do IFAM em relação a QVT.

Após investigação, é possível afirmar que o objeto de estudo valoriza seus funcionários e se importa com o seu bem-estar. Ainda assim, é imprescindível que a gestão estratégica de pessoas realizada pelo instituto seja encarada de forma séria, e que seu capital intelectual continue sendo valorizado.

Ademais, deseja-se que os resultados obtidos com este estudo contribuam para novas pesquisas e que por meio dele seja estendida a conscientização sobre a importância dos indivíduos dentro da organização tal como da gestão estratégica de pessoas. Espera-se também que novas ações sejam tomadas em benefícios dos docentes e técnicosadministrativos.

Disponível em: <goo.gl/9zost8>. Acesso em: 10 abr. 2018

[2]. AZIZ, M.M. et al. Prevalência e fatores associados ao acesso a medicamentos pela 
população idosa em uma capital do sul do Brasil: um estudo de base populacional. Cadernos de Saúde Pública, v. 27, p. 1939-1950, 2011.

[3]. ASSUNÇÃO, S. A. O planejamento estratégico e o processo decisório como ferramentas de auxílio à tomada de decisão numa empresa de pequeno porte. 2016. 43 f. Trabalho de Conclusão do Curso de Ciências contábeisUniversidade Federal do Rio Grande do NorteNatal/RN.

[4]. BARDIN, L. Análise de conteúdo. Tradução Luís Antero Reto e Augusto Pinheiro. Lisboa: Edições 70, 2002.

[5]. BEZERRA, A.M. Todos precisam ter uma boa qualidade de vida. Em entrevista ao RH.com.br. 2007. Disponível em: <http:/www.rh.com.br/ler. php?cod=4587\&org=2>. Acesso em: 11 abr. 2018.

[6]. BRIGHENTI, G. C.; SILVA, A. B.; FERNANDES, C. B. Qualidade de vida no trabalho: um estudo dos fatores e dimensões presentes e percebidas na central de relacionamento com os clientes da TIM celular de Santa Catarina. In: ENCONTRO ANUAL DA ANPAD, XXVI., 2002, Salvador. Anais... Salvador: ANPAD, 2002. Disponível em: < https://goo.gl/3wuvvY > Acesso em: 16 abr. 2018.

[7]. CÂMARA, R. H. Análise de conteúdo: da teoria à prática em pesquisas sociais aplicadas às organizações. Gerais: Revista Interinstitucional de Psicologia, v. 6, n. 2, p. 179-191, 2013. Disponível em: < https://goo.gl/djAh1G >. Acesso em: 5 abr. 2018.

[8]. FRANCISCO, T. H. A. et al. A contribuição do PDI nas atividades de planejamento e gestão das instituições de educação superior. Revista Gestão Universitária na América Latina - Gual, [s.l.], v. 5, n. 3, p.81-107, 21 dez. 2012. Universidade Federal de Santa Catarina (UFSC). Disponível em: < https://goo.gl/vhVrb7>. Acesso em: 10 abr. 2018.

[9]. FROSSARD, M. C. Qualidade de vida no serviço público: um programa para a Agência Nacional do Petróleo, Gás Natural e Biocombustíveis - ANP. [Online]. Fundação Getúlio Vargas. Rio de Janeiro, 2008. Disponível em: <https://goo.gl/BsnWGy>. Acesso em: 11 abr 2018.

[10]. GIL, A. C. Métodos e técnicas de pesquisa social. 6. ed. São Paulo: Atlas, 2008
[11]. GUERREIRO, M. S. A qualidade de vida no trabalho dos servidores do IFAM campi Manaus e o reflexo na produtividade organizacional. 2013.

[12]. INSTITUTO FEDERAL DE EDUCAÇÃO, CIÊNCIA E TECNOLOGIA DO AMAZONAS - IFAM. Manual do Servidor 2015. Disponível em: <http://200.129.168.182:4030/attachments/downloa d/9948/MANUAL\%20DO\%20SERVIDOR\%20IFAM\%20CGBQV.pdf>. Acesso em: 6 abr. de 2018

[13]. Planejamento Estratégico 20082011. Disponível em: <https://goo.gl/rNrgDo>. Acesso em: 6 abr. de 2018.

[14]. PDI - Plano de Desenvolvimento Institucional 2009 - 2013. / Instituto Federal de Educação, Ciência e Tecnologia do Amazonas, IFAM. - Manaus: IFAM, 2009. Disponível em: <https://goo.gl/SHZRiH > Acesso em: 6 abr. de 2018.

[15]. PDI - Plano de Desenvolvimento Institucional 2014 - 2018. / Instituto Federal de Educação, Ciência e Tecnologia do Amazonas, IFAM. - Manaus: IFAM, 2014. Disponível em: <https://goo.gl/XHjXGk>. Acesso em: 6 abr. 2018.

[16]. KAPLAN, R. S.; NORTON, D. P. A estratégia em ação: Balanced Scorecard. Rio de Janeiro: Campus, 1997.

[17]. MASCARENHAS, A. O. Gestão Estratégica de Pessoas. São Paulo: Cengage, 2008.

[18]. MINAYO, M. C. de S. (Org.). et al. Pesquisa social: Teoria, método e criatividade. 30. ed. Petrópolis, RJ: Vozes, 2011.

[19]. OLIVEIRA, P. M.; LIMONGI-FRANÇA, A. C. Avaliação da gestão de programas de qualidade de vida no trabalho. RAE-eletrônica, v. 4, n. 1, 2005 .

[20]. RODRIGUES, M. V. Qualidade de vida no trabalho: evolução e análise gerencial. Rio de Rio de Janeiro: Vozes, 2007.

[21]. SOUZA, C. B. Gestão de Desempenho por competência na Administração Pública Federal. Revista Científica Multidisciplinar Núcleo Do Conhecimento. São Paulo, n.2, p. 58-76, out. 2017.

[22]. XAVIER, C. F. A Importância da Gestão Estratégica de Pessoas nas Empresas, 2011. Disponível em: < https://goo.gl/WxM2Ao> Acesso em: $\quad 9 \quad$ abr. 2018 


\section{Gapítulo 14}

\section{SOCIAL CRM: CONCEITOS, APLICAÇÕES E SOLUÇÕES}

\section{Adriano Carlos Moraes Rosa}

Fulvia Carolina Alves Correa

Matheus Augusto de Lima Faria

Maycon Douglas do Nascimento Zangrandi

Resumo: O presente artigo trata da evolução, funcionamento básico, estudo de caso e ainda, apresenta algumas soluções disponíveis no mercado do Social CRM, evolução do Customer Relationship Management (CRM). O Social CRM, ou SCRM diferentemente do CRM, se apoia no uso de redes sociais tanto para alimentação dos processos e dos sistemas interligados na empresa quanto para divulgação de produtos, marcas, promoções e afins, podendo alcançar um número maior de possíveis clientes e, aumentando assim, o histórico de preferências e informações gerais sobre os mesmos, o que facilita e muito a criação de padrões de consumo. Dessa forma, o objetivo geral desta pesquisa é analisar a melhoria da qualidade do relacionamento com o cliente através do uso do Social CRM. A metodologia utilizada foi a pesquisa exploratória bibliográfica apoiada por pesquisa documental (caso real). Com esse artigo foi possível aumentar o conhecimento sobre essa ferramenta pouco utilizada no Brasil e, desta forma, contribuir para a literatura do assunto. 


\section{INTRODUÇÃO}

A sociedade está em constante transformação e isso reflete na crescente competitividade do mercado. Empresas estão sempre procurando inovar e atualizar tanto em ações que permeiam o aperfeiçoamento de processos, quanto na ampliação de valor. Buscam incansavelmente por vantagens competitivas e, ao investir na otimização de processos direcionados ao melhor atendimento dos clientes, percebem aumento de vendas refletidas, portanto, em lucros. Profissionais de comunicação são treinados nessas empresas para construírem relacionamentos duradouros e positivos com seus clientes, seja na forma de assessoria, utilizando veículos de comunicação, seja na forma de lobby quando esse público é o governo, seja internamente na empresa convencional, quando o público alvo são também seus colaboradores que interagem por meio de mídias sociais. Diante dessa realidade, Jamieson (2014) reafirma que as companhias estão cada vez mais utilizando recursos tecnológicos como o sistema de Gestão de Relacionamento com o Cliente ou CRM que significa Customer Relationship Management e, por consequência, a evolução desse sistema, o Social CRM (SCRM), que oferece uma "camada a mais de organização" abordando atividades de mídia social dentro da empresa proporcionando um diálogo mais direto com os seu público de interesse, passando a enxergar a empresa como parte de sua realidade, e não mais como uma grande corporação distante do seu dia a dia.

A problemática trabalhada diz respeito a necessidade de desenvolvimento de estratégias de comunicação digital para cada público de interesse e, com isso, tornar possível conhecer os seus gostos e preferências, conhecendo quem ele é e qual é a sua necessidade. Já a hipótese defendida pelos autores e respectivas fonte é que o uso e aplicação desta ferramenta (SCRM) em determinadas empresas facilita a visualização de informações e podem gerar muito mais acertos na tomada de decisões que um sistema convencional, pois, quando se trabalha com um público que pode obter informações através de redes sociais, este fornece dados úteis que serão analisados pela equipe de inteligência da empresa, que irão otimizar e apurar o processo de postagens melhorando o relacionamento e discussões inter e intraorganizacional.

\section{JUSTIFICATIVA}

Este estudo objetiva principalmente mostrar os benefícios da inclusão das ferramentas do SCRM nas organizações e o respectivo relacionamento entre cliente/consumidor através das mídias sociais integradas com a empresa. Como objetivos específicos se propõe elaborar uma pesquisa bibliográfica para atualizar os conceitos; elaborar o texto a luz de exemplos reais; multiplicar a comunidade acadêmica e empresas de área interessadas ou atuantes na área, além de testar a capacidade dos autores na elaboração de um artigo original.

Para estes objetivos, escolheu-se como metodologia as pesquisas exploratórias bibliográfica e documental, que a frente são melhor explanadas (materiais e métodos).

\section{REFERENCIAL TEÓRICO}

Para contextualizar o tema, procurou-se registrar a importância da TI somada a Logística e a história do CRM, a definição de SCRM e sua relação com empresas públicas. Da mesma forma, preocupou-se também com o entendimento do funcionamento da ferramenta e sua respectiva aplicação prática.

\subsection{IMPORTÂNCIA DA TI E LOGÍSTICA: ÁREAS PARES}

Bowersox, Closs e Cooper (2001) afirmam serem cinco os fatores principais que levam às operações globalizadas excelentes e, estes cinco fatores podem ser reconhecidos como: crescimento econômico; a abordagem da cadeia de suprimento (contratação de serviços externos); a desregulamentação (financeira e de transportes); a regionalização (necessidade de desenvolver novos mercados) e; a tecnologia (ou o aumento da capacidade para a troca de informação).

Já Ballou (2006) considera que existem atividades chave e atividades de suporte à logística, sendo consideradas atividades de suporte a armazenagem; o manuseio de materiais; compras; embalagens; cooperação com produção e operações; manutenção de informação (coleta, arquivamento e manipulação de informação; análise de dados; procedimentos de controle). Já as atividades chave da cadeia de suprimentos o autor (BALLOU, 2006) lista o transporte; a administração de estoques; os padrões de serviço ao cliente; fluxo de informações e 
processamento de pedidos (procedimentos de interface dos estoques com pedidos de vendas; métodos de transmissão de informações de pedidos; regras de pedidos), toda a tecnologia e ferramentas agregadas (Figura 1).

Figura 01: Fluxo de Informações como Atividades Chave na Cadeia de Suprimentos

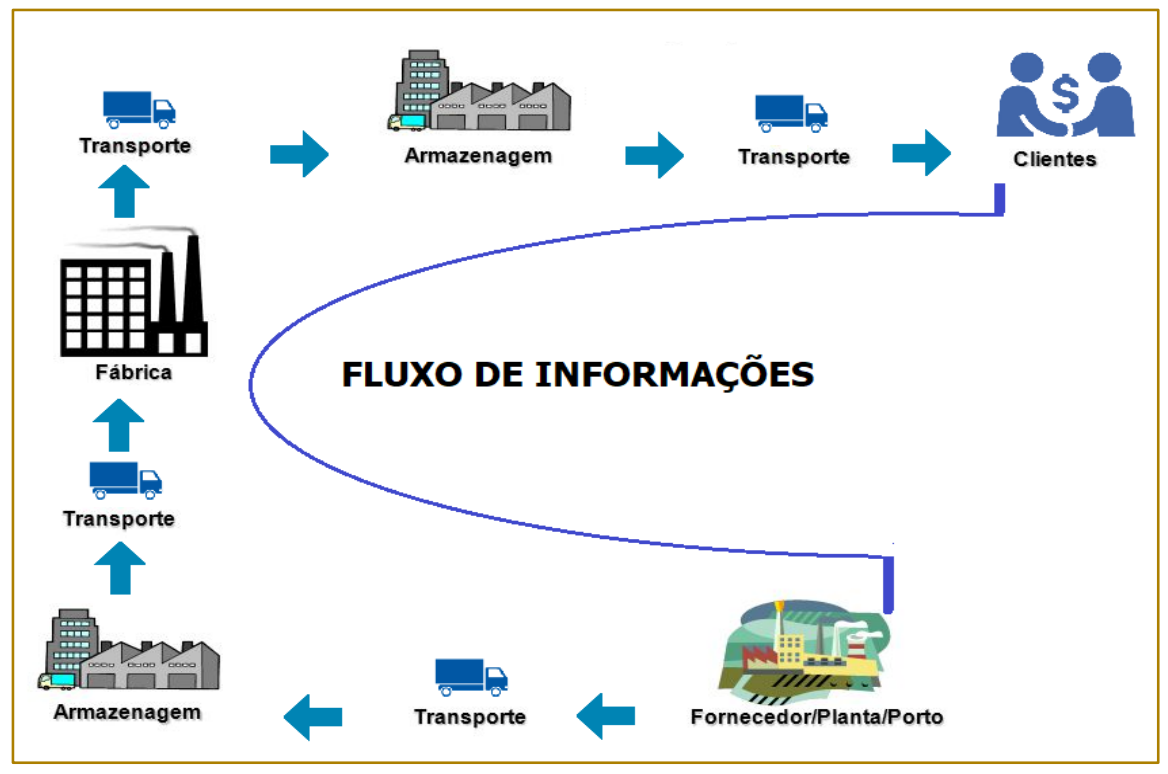

Fonte: Adaptado de Ballou (2006)

\subsection{CRM CUSTOMER RELATIONSHIP MANAGEMENT}

Cronologicamente, o CRM surgiu na década de 1990. O CRM é decorrência da evolução tecnológica dos softwares de gestão empresarial e de informação, por meio do relacionamento com o cliente, que visa maior lucratividade e ganhos de vantagem competitiva (MADRUGA, 2010; MEDEIROS, 2013). Em outras palavras, o CRM na sua origem, também se trata de uma solução de Tecnologia da Informação (TI) especialmente concebida para as ações de Marketing de Relacionamento, entretanto, com cuidado especial ao consumidor, ou seja, relacionamentos individuais com os clientes.

O que se entende é que a TI proporciona importantes mudanças no relacionamento entre empresas e seus consumidores, no entanto, estes últimos contam com variadas opções de escolha entre produtos e serviços, o que torna cada vez mais difícil a tarefa das as empresas em atrai-los e torná-los fiéis. Mazza (2009) corrobora, explicando sobre a estratégia em sua essência, ampliada com o CRM:

[...] a estratégia em sua essência, tem como objetivo principal o aumento nas vendas verticais dentro de um mesmo consumidor ou grupo de mesmas características, diferentemente das empresas que ganham muitos clientes através do aumento no número de consumidores horizontais. Empresas de CRM normalmente têm um grande número de produtos em seu portfólio e, com isso, a necessidade de vende o máximo possível dentro do potencial de compras deste consumidor (MAZZA, 2009, p.11)

Grönroos (2000) também colabora com o assunto, declarando que os objetivos do CRM é realizar, manter e aumentar relacionamentos lucrativos com os consumidores, estratégia de negócio que por meio da tecnologia captura dos clientes informações $e$ as organiza para poder realizar estratégias e criar importantes métodos de identificar e valorizar o cliente. Desta forma, então, o CRM integra pessoas, processos e tecnologia para aperfeiçoar o gerenciamento de todos os relacionamentos e, por isso, não devem ser considerados puramente tecnológico, como um pacote de software. Portanto, o CRM também deve ser visto como uma nova maneira de fazer negócios, com a integração entre estratégias do marketing de relacionamento e tecnologias de informação e comunicação. 


\subsection{DEFINIÇÃO DE SOCIAL CRM}

Existem muitas formas de se definir o que é Social CRM ou SCRM e, de acordo com Lacy Diamond e Ferrara (2012) e Medeiros (2013) a ideia básica é que várias unidades de negócios interagem usando mídias sociais com a capacidade de sobrepor o CRM tradicional com dados sociais que constroem relacionamentos melhores e mais duradouros, representando um "paradigma real" na forma como as empresas realizam negócios, colocando o cliente no centro do mesmo, guiando seus processos principais, como por exemplo marketing, desenvolvimento de produtos e produção.

O SCRM passa a fazer parte dos negócios quando os líderes empresariais optam por uma maneira melhor de gerenciar seus contatos e clientes através de uma estratégia aliada na aplicação da inteligência de mercado nas companhias, cujo propósito é o mapeamento de interesses dos clientes, comportamento de prospecções, monitoramento da concorrência e o norteamento para decisões assertivas (WOODCOCK; GREEN; STARKEY, 2011). Para isso, conforme Moura et al. (2014), é preciso que a área de TI desenvolva soluções para dar conta da demanda, pois 0 monitoramento das mídias sociais requer uma intervenção humana maior do que se pode imaginar, com a coleta de comentários e as mais variadas análises que resultam exatamente no que as empresas procuram: os sentimentos sobre marcas e produtos expressados pelos usuários durante diálogos em redes como Facebook, Twitter, Linkedln, entre outras.

\subsubsection{A RELAÇÃO DO SCRM E AS EMPRESAS PÚBLICAS}

Segundo Souza (2008), o SCRM representa uma nova visão das relações públicoempresarial e clientes, criando interações entre eles e, com ele, empresas devem manter um melhor controle da comunicação, reforçar marca e oportunizar aumento de ganhos com as vendas. Se baseia na construção de relações personalizadas com os clientes através de mídias sociais e aperfeiçoamento de relacionamentos resultantes em inovações, melhoria de imagem e marca, assim como, fortalecimento do conhecimento dos clientes com as ações realizadas pela empresa pública.

O SCRM não funciona apenas como um instrumento de monitoramento de mídias, mas, como um conjunto de elementos interligados preparado para cooperar em reconhecer dados e, logo, orientar o gestor na tomada de decisão, entretanto, para que funcione, é necessário que primeiro se ajustem sistema e cultura organizacional (FAASE; HELMS; SPRUIT, 2011; MEDEIROS, 2013). Para Pattik (2012), o SCRM funciona "sim" como uma ferramenta de negócios que fornece dados às empresas objetivando uma melhor "leitura" de seus clientes, dados esses que são apurados através de diálogos e convívio com esses clientes ou potenciais clientes através diversos canais (mídias sociais, fóruns, SAC, comunidades, centrais de venda, etc.), ou seja, onde pessoas se interessarem, falarem e opinarem sobre a marca ou empresa, se abre uma porta de dados que permite captação de informações.

Já para Evans, o SCRM convida o cliente a integrar a empresa (2010):

[...] O SCRM convida o cliente para fazer parte da empresa ou organização em um processo chamado de colaboração. [...] Esse tipo de colaboração envolve todo o conjunto das partes interessadas no negócio ou organização, incluindo seus funcionários, parceiros e fornecedores. É um negócio orientado para o futuro, e é essencial uma estratégia que esteja focada em "encantar" os clientes (EVANS, 2010, p.39).

Caso um cliente mencione um serviço ou produto, o SCRM analisa qual o contexto da mensagem e o sentimento (negativo, positivo) expresso pela pessoa, gerando para a empresa uma possibilidade de responder rapidamente e contornar possíveis crises ou agradecer e interagir com os usuários. Essa ação também cria uma ótima oportunidade para a comunicação, marketing e networking entre os pares. O funcionamento do SCRM se dá como ilustrado na Figura 2: 
Figura 02: Funcionamento do SCRM

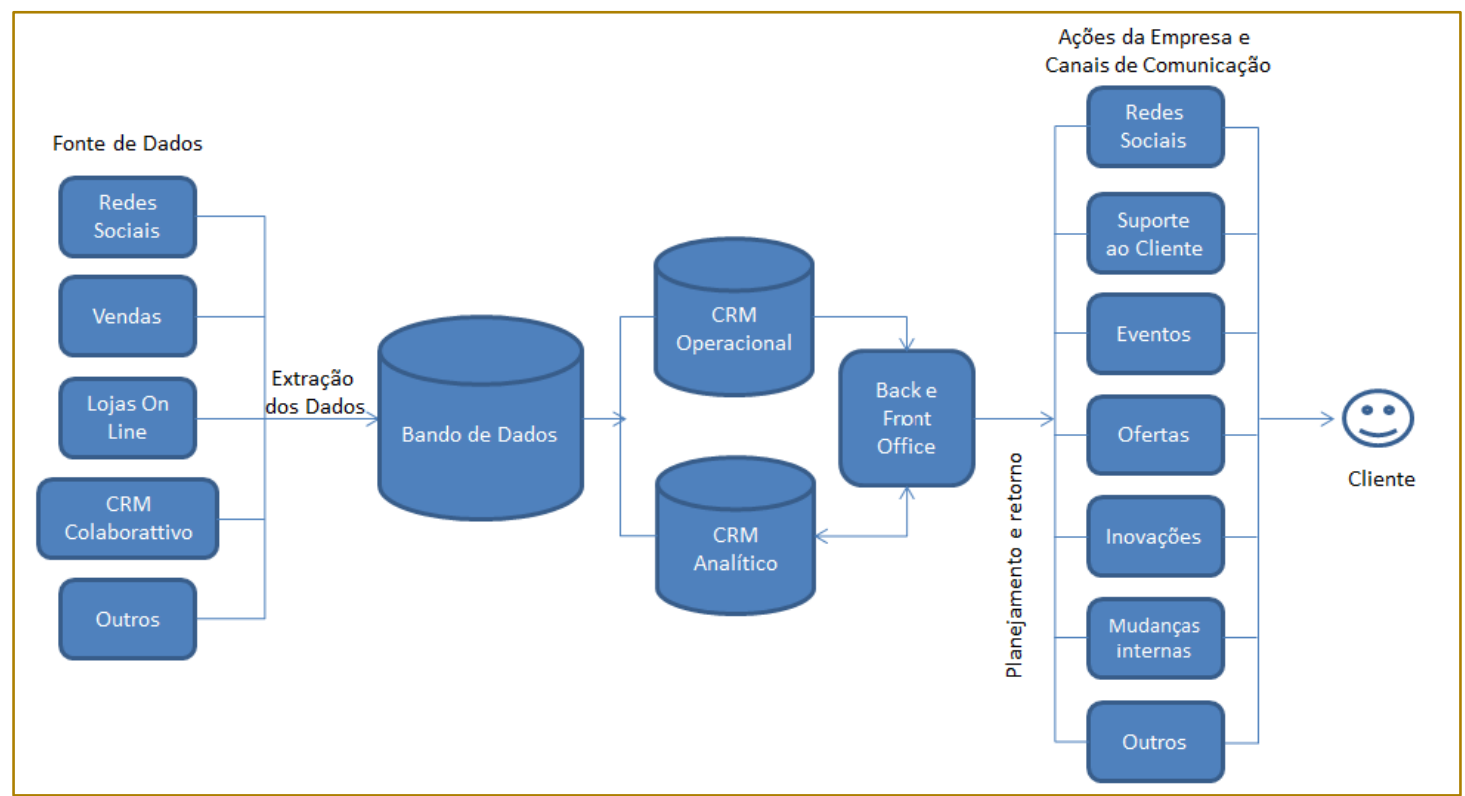

Fonte: Elaborada pelos autores

Conforme a Figura 02, são diversas as fontes de dados que alimentam um CRM, vão desde a captura de dados por meio de formulários escritos à mão até cupons de compra em lojas físicas e/ou on-line. No SCRM, essa captura se estende às redes sociais, ambiente onde informações de clientes, futuros clientes, concorrentes e afins trafegam. Os dados, depois de extraídos, alimentam um grande banco de dados, que então, alimenta o CRM Operacional e o Analítico (Datawarehouse responsável pela análise das informações). Ambos enfim, enviam informações para todos os "sistemas legados" da empresa (Back e Front Office) momento este, em que acontece todo o planejamento estratégico, mudanças, melhorias dos processos e produtos, identificação de oportunidades (por exemplo, criação de novos produtos ou até a alimentação dos que não geram um determinado valor ao negócio). Toda essa prática guia o retorno ao cliente que pode ser via rede social, TV, promoções, eventos e mudanças.

\subsubsection{SOLUÇÕES SOCIAL CRM:}

Como soluções propostas, foram selecionadas 3 ferramentas SCRM, Sprout Social, CRM Dynamics e Siebel CRM On Demand.

Sprout Social: ferramenta para gestão e engajamento em mídias sociais que oferece também soluções específicas para corporações, agências e pequenas empresas. Propõe fornece base para relacionamento e melhor atendimento ao cliente, além de análises e estatísticas. Podem ajudar a equipe a monitorar, responder, medir e colaborar com uma comunicação mais inteligente e rápida (MARTI; GANESAN; GARCIA-MOLINA, 2004).

CRM Dynamics: ferramenta ajuda a proporcionar experiências excepcionais aos clientes, criando relacionamentos de longo prazo com base em conhecimento e confiança e, um exemplo é o Microsoft Dynamics CRM 4.0 que se trata de um sistema integrado de CRM. Permite criar e manter facilmente uma visão clara dos clientes, do primeiro contato até a pós-venda e oferece ferramentas de melhoria de processos de vendas, marketing e serviço de atendimento ao cliente, o Microsoft Dynamics CRM oferece suporte, serviços e recursos flexíveis de mercado que permitem resolver rapidamente problemas técnicos, aprofundar o conhecimento profissional e maximizar o Retorno do Investimento - ROI (AMARAL, 2009).

Siebel CRM On Demand: oferece um completo conjunto de recursos para automação de vendas, marketing e atendimento, sem nenhum investimento inicial de TI. Fornece recursos e funcionalidade exclusivos, incluindo análise incorporada e data warehouse pré-construído para 
promover a tomada de decisões em tempo real, call center virtual integrado para suporte aos atendentes sem a necessidade de infraestrutura de telefonia e edições para setores específicos, que ajudam a reduzir ainda mais tempo, mão-de-obra e custos associados à configuração (ORACLE, 2006)

\section{MATERIAIS E MÉTODOS}

Para Gil (2005) a pesquisa exploratória é desenvolvida com objetivo de proporcionar visão geral, de tipo aproximativo, acerca de determinado fato e, neste artigo, o fato consiste no suporte da importância da gestão de informações na Logística e distribuição de produtos. O autor (GIL, 2005) também explica que as pesquisas exploratórias podem envolver levantamento bibliográfico e documental, ferramentas utilizadas neste artigo.

O estudo realizado contempla analisar a melhoria da qualidade do relacionamento com o cliente através do uso do SCRM, tema e problema trabalhados a partir de referenciais teóricos publicados em documentos (CERVO; BERVIAN, 2002).

Assim, também, se-utilizou de pesquisa documental, que conforme Marconi e Lakatos (2012), objetiva investigar fontes primárias, que se constituem de dados que não foram codificados, organizados e elaborados para os estudos científicos (documentos, arquivos, desenhos, fotografias, etc.), para poder descrever e analisar as situações, fatos e acontecimentos anteriores, comparando-se com os dados da realidade.

\section{RESULTADOS E DISCUSSÃO}

São vários os casos de sucesso de SCRM que apresentam resultados positivos por todo o mundo. No Brasil, podem ser citadas as empresas Ponto Frio, Coca-Cola Brasil e Embraer, exemplos pesquisados neste artigo para tornar a discussão sobre a ferramenta ainda mais rica e inequívoca.

Ponto Frio: na rede brasileira Ponto Frio, que, com o personagem "Pinguim", conquistou os usuários do Twitter e Facebook. O personagem é fruto do trabalho de uma equipe de Social Media que atua de forma integrada (como sugere BALLOU (2006) no trato do fluxo de informações) com as outras áreas da empresa, desde o setor comercial até o de atendimento. Atualizando os perfis constantemente, o "Pinguim" utiliza as redes sociais para divulgar promoções, serviços e produtos comercializados pela rede $e, \quad o$ diferencial, porém, está no modo como ele inicia um relacionamento com seus seguidores ou fãs, pois se trata de mensagens simples, como "Bom dia!" e "Boa noite!", aproveitando-se de datas comemorativas, "memes" da internet e temas mais comentados no momento (como em JAMIESON, 2014). A equipe depois de analisar dados, esquematiza suas postagens relacionando as discussões com seus produtos e serviços. A combinação agrada não apenas os consumidores da loja, mas conta com a aprovação dos internautas, no geral, que não hesitam em participar e demonstrar seu "carinho" pelo Pinguim (como em MARTI; GANESAN; GARCIA-MOLINA, 2004)

Coca-cola: segundo Clientesa (2012) nesta empresa a implementação do Siebel On Demand obteve muito sucesso, pois permitiu monitorar de maneira integrada todos os canais de atendimento como Twitter, Facebook, site, etc. (como propõe MEDEIROS, 2013) na qual um único CRM já incluía o e-mail, em parceria com a Triscal. Eficiência, agilidade e atenção sempre foram palavras de mandado quando o assunto é relacionamento com o consumidor. Seja para solucionar dúvidas, registrar reclamações, sugestões e elogios, o cliente final tem de ser atendido com rapidez e eficácia. O comprador final que está em toda parte, utiliza cada vez mais meios de comunicação, se expressa e quer dividir momentos, assim, a companhia decidiu aprimorar seu sistema de gestão para integrar todos seus canais de atendimento em um único sistema de CRM e, integrar o controle e a gestão de todos os chamados e meios de comunicação é a única forma de oferecer um atendimento ágil e eficaz para ampliar a interação dela com os consumidores, usufruindo do SCRM (como em EVANS, 2010; PATTIK, 2012). Um dos grandes benefícios do novo processo e protocolo de atendimento é que o sistema, quando executa o controle de eventos, o realiza com base nos dados do próprio cliente, independente do canal de atendimento, o que resulta na diminuição de registros de informações duplicadas e, caso um cliente faça uma ocorrência em mais de um canal, não haverá duplicidade, seja por telefone, e-mails, site, Twitter ou Facebook, todas as manifestações são acompanhadas, 
registradas e atendidas de maneira integrada (CLIENTESA, 2012)

EMBRAER: implantou uma plataforma de SCRM com o objetivo de integrar processos, gerenciar negócios e o relacionamento com clientes (WOODCOCK; GREEN; STARKEY, 2011). Os fatores principais para a aderência desta são as necessidades dos processos de vendas de serviços e as possibilidades para melhorias na colaboração com clientes (SALESFORCE, 2016). O uso da ferramenta na gestão de eventos sem necessidade de grandes esforços de desenvolvimento, a possibilidade de integração com outros bancos de dados e a facilidade para futuras integrações com portais de relacionamento também são considerados grandes atrativos. A plataforma permite interagir com o cliente de maneiras diferentes, por vários canais, em um contexto móvel e social, (SOUZA, 2008), possibilitando acelerar negócios, criar contratos e obter informações de inteligência, assim, a equipe da empresa determina estratégias de aumento de valor agregado, satisfação para os clientes por meio de serviços com valores mais competitivos e, consecutivamente, aumentando as receitas (JAMIESON, 2014; SALESFORCE, 2016).

\section{CONSIDERAÇÕES FINAIS}

Considerada e comprovada como uma eficiente estratégia de gestão de relacionamento com clientes, o CRM ganha cada vez mais espaço nas empresas, inclusive as nacionais, que conseguem, através dessa ferramenta, obter informações importantes para a satisfação e fidelização dos clientes. De acordo com as pesquisas, das novas necessidades desse agora denominado "consumidor social", surge a

\section{REFERÊNCIAS}

[1]. AMARAL, J. Conceptualização de Uma Aplicação CRM Para o Serviço Pós-venda. Dissertação, Departamento de Economia, Gestão e Engenharia Industrial da Universidade de Aveiro, Portugal, 2009.

[2]. BALLOU, R. H. Gerenciamento Da Cadeia de Suprimentos - Logística Empresarial. 5ạ. Ed. Porto Alegre (RS): Bookman, 2006.

[3]. BOWERSOX, D.; CLOSS, D.; COOPER, M. Gestão da Cadeia de Suprimentos e Logística. 2a Ed. Rio de Janeiro, Elsevier, 2008. estratégia do SCRM, destinado a um cenário onde ascendem e imperam as redes sociais. Clientes mudam culturas e passam a usar essas redes além da comunicação, como por exemplo, para comprar, vender e pesquisar em seus negócios.

Como visto nos casos e discussão apresentados, essa nova estratégia permite realmente que empresas trabalhem e que interajam com seus clientes cada vez mais próximas, credenciando assim, mais ações de relacionamento positivo eles, e, registra-se também através deste trabalho uma certa preferência desses clientes pelo uso das principais redes sociais como meio de relacionamento com as empresas, que, comprovadamente cresce potencialmente no Brasil.

As contribuições que este estudo trouxe para a formação profissional como gestores, foi identificar um sistema de informação que contribui para melhores resultados na empresa, como o SCRM. Ajuda as organizações de qualquer dimensão a atingir seus objetivos de forma mais assertiva. Também, como ponto importante e favorável, o SCRM pode guiar um produto, processos internos, mais marketing estratégico de venda com dados e informações extraídas dos próprios clientes, portanto, SCRM é muito mais que uma simples ferramenta, faz parte de uma metodologia estratégica que por meio do estabelecimento significativo do relacionamento com o cliente promovem a transparência e da mais "poder" de influência aos consumidores garantindo a boa reputação da marca e aumentam a fidelidade do mercado para com ela. Diante do exposto, acredita-se que os objetivos propostos neste artigo foram cumpridos.

[4]. CERVO, A.; BERVIAN, P. Metodologia Científica. 5a․ Ed. São Paulo: Prentice Hall, 2002.

[5]. CLIENTESA. Coca-Cola Brasil Vira Referência Mundial, maio 2012. Disponível em: <http://www.clientesa.com.br/gestao/46087/cocacola-brasil-vira-referencia-mundial/ler.aspx>. Acesso em: 10/02/2018.

[6]. EVANS, D. Social Media Marketing: The Next Generation of Business Engagement. USA: Sybex, 2010. 
[7]. FAASE, R.; HELMS, R.; SPRUIT, M. Web 2.0 in the CRM domain: defining social CRM. International Journal of Electronic Customer Relationship Management, vol. 5, issue 1, p. 1-22, 2011.

[8]. GIL, A. Metodologia do Ensino Superior, 4ª . Ed. São Paulo: Atlas, 2005

[9]. GRÖNROOS, C. Relationship Approach to the Marketing Function in Service Contexts: the marketing and organizational behavior interface. Journal of Business Research, vol. 20, n. 1, p. 3 12, 2000.

[10]. JAMIESON, C. The Small Business Guide to Social CRM. Publisher Packt Publishing / ImPackt Publishing, USA, 2014

[11]. LACY, K.; DIAMOND, S.; FERRARA, J. Social CRM for Dummies. New Jersey: John Wiley \& Sons Inc: 2013.

[12]. MADRUGA, R. Guia de Implementação de Marketing de Relacionamento e CRM. $2^{-a}$ Ed. São Paulo: Atlas, 2010.

[13]. MARCONI, M.; LAKATOS, E. Técnicas de Pesquisa. 7a. Ed. São Paulo (SP): Atlas, 2012.

[14]. MARTI, S.; GANESAN, P.; GARCIAMOLINA, H. SPROUT: P2P routing with social networks. EDBT 2004 Workshops. EDBT 2004. Lecture Notes in Computer Science, vol. 3268. Springer, Berlin, Heidelberg, 2004.

[15]. MAZZA, M. F. CRM: sucessos \& insucessos. Rio de Janeiro: Brasport, 2009.

[16]. MEDEIROS, D. N. Planejamento de Ações Corporativas em Mídias Sociais: conceitos e práticas. Centro de Educação Superior de Brasília,
Instituto de Educação Superior de Brasília IESB. Pós-Graduação em Marketing e Comunicação Digital, Brasília (DF),2013.

[17]. MOURA, A.; GODINHO, L. A.; GOSLING, M.; MARTINS, J. Marketing de Relacionamento Via Redes Sociais: uma análise de sua aplicação. revista eletrônica de administração, vol. 13, issue1, ed. 24, jan-jun, 2014.

[18]. ORACLE. Informação é Valor: CRM completo para optimizar resultados Siebel CRM On Demand. Oracle Corporation, Portugal Lagoas Park, 2006. Disponível em: <http://www.oracle.com/us/6561_pt.pdf>. Acesso em: 12/03/2018.

[19]. PATTIK, K. M. Putting Social Media to Work: a comparative analysis of how businesses are incorporating social media. (Thesis) Department of Mass Communication and Communication Studies. Towson University, Maryland, 2012.

[20]. SALESFORCE. Embraer Implementa Visão $360^{\circ}$ do Cliente com a Salesforce. Salesforce, San Francisco, CA, United States, 2016. Disponível em: <http://www.salesforce.com/br/customers/stories/e mbraer.jsp>. Acesso em: 09/02/2018.

[21]. SOUZA, A. P. Gerência do relacionamento com o cliente CRM - customer relationship management, na gestão de empresas. Trabalho de Conclusão de Curso (Graduação) Universidade Federal do Pará, Faculdade de Computação, 2008.

[22]. WOODCOCK, N.; GREEN, A.; STARKEY, M. Social CRM as a business strategy. Journal of Database Marketing \& Customer Strategy Management. Vol. 18, Issue 1, p. 50-64, 2011. 


\section{Bapítulo 15}

\section{USO DE FERRAMENTAS DE GEOPROCESSAMENTO E ANÁLISES GEOESTATISTICAS PARA EVIDENCIAR O STATUS DA ATENÇÃO BÁSICA À SAUUDE OFERTADA PELO MUNICÍPIO DE JACAREÍ.}

\section{Deivid Márlon Fernandes da Costa}

Vitor Luíz Monteiro Júnior

Sanzara Nhiaia Jardim Costa Hassmann

Resumo: As políticas públicas ao mesmo tempo em que colocam o governo em ação, elas analisam a eficácia e eficiência destas ações. Um exemplo prático de política pública que está dentro do aspecto social da Infraestrutura Urbana e atualmente constitui em uma obrigação legal é o Sistema Único de Saúde. Tal sistema é hierarquizado em níveis básico, secundário e terciário de atenção à saúde e como modelo de atenção básica à saúde (nível terciário) tem-se a Estratégia de Saúde da Família, regulamentada pela Política Nacional de Atenção Básica à Saúde. Conforme esta regulamentação planejar, apoiar, monitorar e avaliar as ações de atenção básica à saúde é de responsabilidade comum de todas as esferas do governo. Assim, este trabalho objetiva evidenciar o status da atenção básica à saúde em relação aos serviços prestados pelas unidades médicas de saúde da família à população do município de Jacareí. Para alcançar tal objetivo, foram aplicados conceitos e técnicas de geoprocessamento e análises geoestatísticas. Os resultados obtidos demonstraram informações úteis e críticas sobre a atenção básica a saúde correlacionando o "status" de conformidade das unidades versus a dispersão da SUS-depenência.

Palavras-chave: Geoprocessamento. Geoestatística. Saúde Pública.

*Artigo publicado no 9 Congresso Internacional de Logística da Faculdade de Tecnologia 


\section{INTRODUÇÃO}

Segundo Zmitrowicz e Neto (1997), o conjunto de sistemas técnicos de equipamentos e serviços necessários ao desenvolvimento das funções urbanas é conhecido como infraestrutura urbana. Estas funções são definidas em aspecto social, econômico e institucional. O desempenho destas funções urbanas é regido e provém de políticas públicas que constitui em assunto que ainda não possui definição única ou exata, sendo um campo multidisciplinar que repercute nas inter-relações entre Estado, política, economia e sociedade. Assim, pode-se dizer que as políticas públicas ao mesmo tempo em que colocam o governo em ação, elas analisam a eficácia e eficiência destas ações (SOUZA, 2006). Um exemplo prático de política pública que está dentro do aspecto social da Infraestrutura Urbana e atualmente constitui em uma obrigação legal (SANTOS, 2013) é o Sistema Único de Saúde (SUS). Este sistema é hierarquizado em níveis básico, secundário e terciário de atenção à saúde (QUINELLATO, 2009) e conforme a Política Nacional de Atenção Básica, planejar, apoiar, monitorar e avaliar as ações de atenção básica à saúde é de responsabilidade comum de todas as esferas do governo. Assim, este trabalho objetiva evidenciar o status da atenção básica à saúde em relação aos serviços prestados pelas unidades médicas de saúde da família à população do município de Jacareí. Para o alcance deste objetivo, foram aplicados conceitos e técnicas de geoprocessamento sobre a territorialização das unidades de saúde da família e análises geoestatísticas para determinação das regiões de maior susdependência.

\section{EMBASAMENTO TEÓRICO}

Segundo a Organização Mundial de Saúde (1995), o termo "saúde" define-se como um estado de completo bem-estar físico, mental e social, e não consiste apenas na ausência de doença ou de enfermidade. Como meio de garantir este completo bem-estar, nacionalmente adota-se o SUS.

O SUS é composto pelo conjunto de ações e serviços de saúde, prestados por órgãos e instituições públicas federais, estaduais e municipais, da Administração direta e indireta e das fundações mantidas pelo Poder Público (lei $n^{\circ}$ 8.080, de 19 de setembro de 1990). Este sistema faz-se regido sobre alguns princípios, sendo válido ressaltar a universalidade, integralidade e equidade (BRASIL, 2000). Para a execução destes princípios, o SUS se organiza em diretrizes (rede, regionalização e hierarquização) que sustentam o modelo de atenção à saúde (art. 198 da Constituição Federal de 1988). A hierarquização consiste em ordenar o sistema nos níveis primário, secundário e terciário de atenção à saúde (QUINELLATO, 2009).

Como modelo de atenção básica à saúde (nível primário de atenção) tem-se a Estratégia de Saúde da Família, regulamentada pela Política Nacional de Atenção Básica à Saúde (portaria ํo 2488/2011). Esta estratégia adota como princípio a prevenção ao invés da remediação e é composta pela distribuição de equipes multiprofissionais que possuem, no mínimo, médico generalista ou especialista em saúde da família ou médico de família e comunidade, enfermeiro generalista ou especialista em saúde da família, auxiliar ou técnico de enfermagem e agentes comunitários de saúde (ACS). O número de ACS deve ser suficiente para cobrir $100 \%$ da população cadastrada, com um máximo de 750 pessoas por agente e de 12 ACS por equipe de Saúde da Família, não ultrapassando o limite máximo recomendado de pessoas por equipe. Cada equipe de Saúde da Família deve ser responsável por, no máximo, 4.000 pessoas de uma determinada área, que passam a ter corresponsabilidade no cuidado com a saúde.

\section{MATERIAIS E MÉTODOS}

\subsection{ESTIMATIVA DE POPULAÇÃO TOTAL ATENDIDA}

Para determinar a conformidade das unidades de saúde da família perante a Política Nacional de Atenção Básica em questão da capacidade máxima de atendimento, foram correlacionadas informações de quantidade de equipes de saúde da família e áreas de abrangência destas unidades versus a estimativa de população total conforme dados disponibilizados pelo censo realizado pelo Instituto Brasileiro de Geografia e Estatística (IBGE) no ano de 2010.

Como dados brutos para obtenção de informações das unidades de saúde da família, foram utilizados o mapa de territorialização da saúde do município de 
Jacareí, disponibilizado em "kml" pela prefeitura e a relação de equipes de saúde da família ativas constantes no Cadastro Nacional de Estabelecimento de Saúde (CNES).

A estimativa de população total residente nos territórios de saúde foi extraída a partir do "shapefile" de setores censitários do IBGE, planilha "Básico_SP2.xIs" e o metadado desta planilha disponibilizado em "pdf".

O software utilizado para tratamento dos dados e correlação das informações foi o QGIS, que constitui um Sistema de Informação Geográfica (SIG) de código aberto licenciado conforme a Licença Pública Geral GNU. Este, é um projeto oficial da Open Source Geospatial Foundation (OSGeo) capaz de operar em ambiente Linux, Unix, Mac OSX, Windows e Android, suportando inúmeros formatos de informações (vetores, matrizes e bases de dados) e funcionalidades (QGIS, 2017).

Primeiramente foram filtrados somente os setores censitários pertencentes ao município de Jacareí, tanto na planilha quanto no shapefile. Após este processo, foi realizada uma "união de tabela de atributos" tendo o atributo código do setor como

chave para fazer com que o shapefile de setores censitários obtenha as seguintes variáveis da planilha "Básico_SP2.xIs":

- "Domicílios particulares permanentes ou pessoas responsáveis por domicílios particulares permanentes" (V001);

- "Média do número de moradores em domicílios particulares permanentes" (V003):

Com o shapefile de setores contendo as variáveis de interesse ao estudo, foram gerados pontos na superfície destes setores a fim de determinar geometrias representativas dos setores e herdando todos os atributos destes. A partir destes pontos criados, aplicou-se o algoritmo no complemento python do próprio software demonstrado na Figura 1.

O algoritmo apresentado primeiramente define objetos de camadas vetoriais que serão utilizados no processo. Neste caso foram definidas as camadas de territórios de saúde da família, de pontos representantes dos setores censitários e uma camada a ser adicionado o resultado final.

Após a construção dos objetos destas camadas, percorre-se primeiro as feições de territórios e, logo em seguida, declara-se um loop para percorrer cada feição da camada de pontos, capturando todos os pontos que estão dentro de cada território percorrido, através da matriz espacial "within".

Ao determinar quais os pontos que pertencem a cada território, obtêm-se a Estimativa de População Total Atendida através da somatória do atributo "EPopTotal" de todos os pontos de cada território.

Figura 1 - Algoritmo python utilizado para cálculo de estimativa da população total.

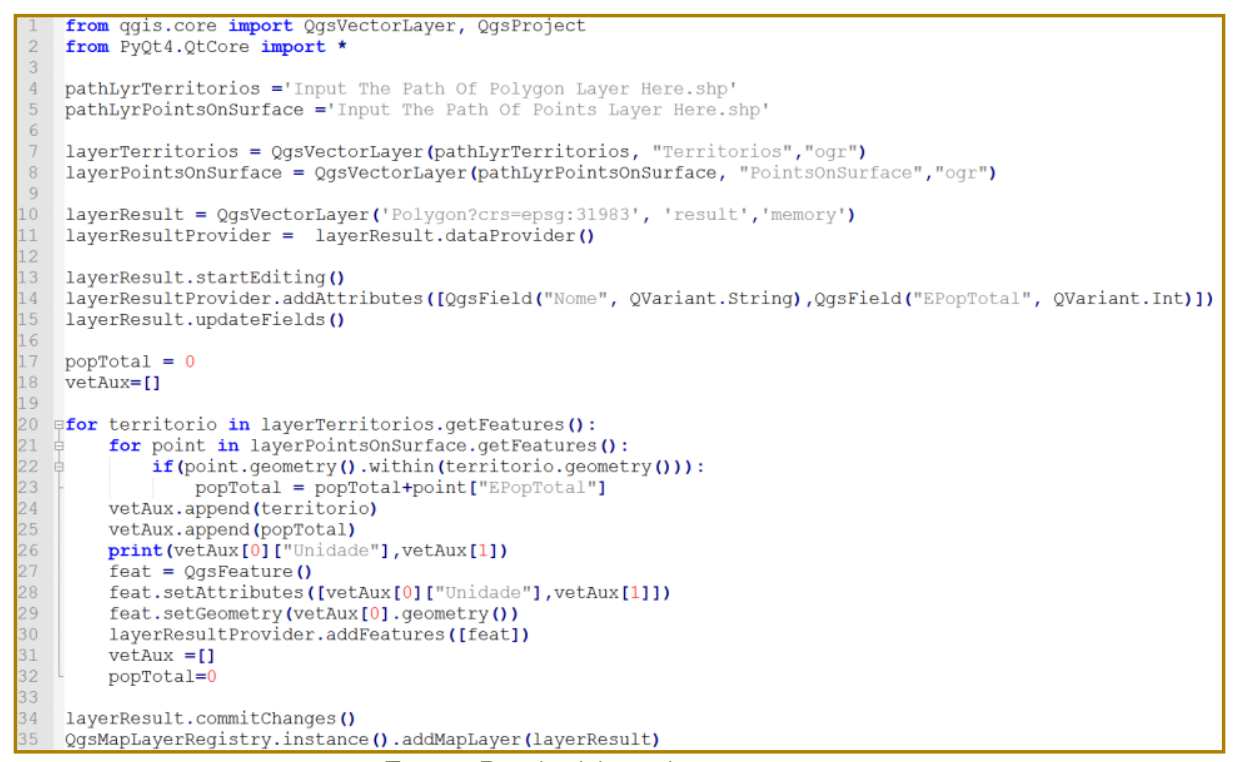

Fonte: Produzido pelos autores. 
Como produto resultante deste algoritmo, obteve-se uma camada vetorial de polígonos representando os territórios de saúde da família contendo a estimativa de população total atendida dentro de cada território (atributo "EPopTotal"), conforme Figura 2.

Figura 2 - Dado produto do algoritmo python.

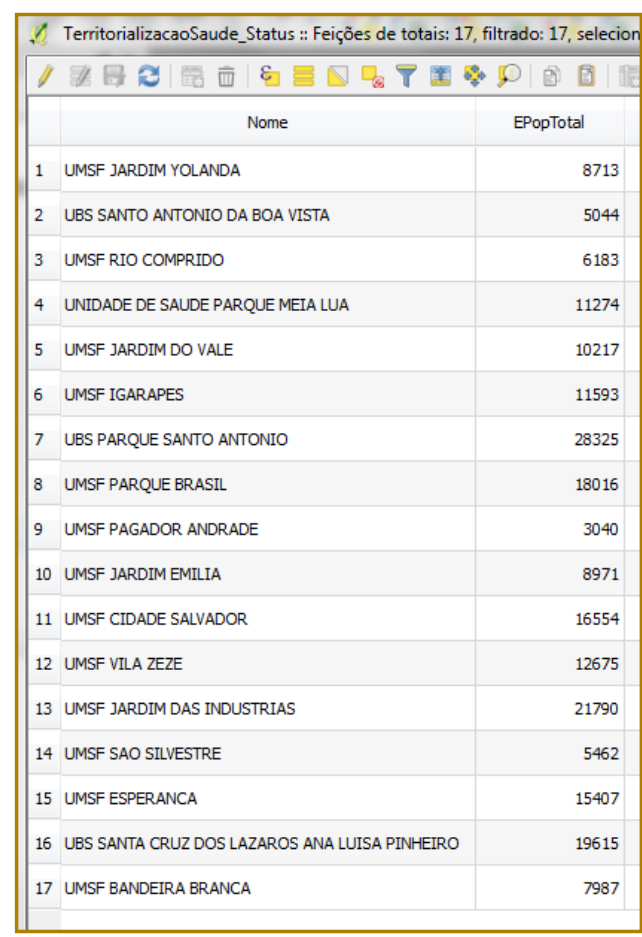

Fonte: Produzido pelos autores.

\subsection{DETERMINAÇÃO DE CONFORMIDADES DAS UNIDADES DE SAÚDE DA FAMÍLIA}

Após a obtenção da estimativa de população total atendida dentro de cada território de saúde, sintetizou-se em uma planilha os registros das equipes de saúde da família ativas em cada unidade conforme disponibilizado no CNES.

Figura 3 - Exemplo de cadastro de estabelecimento de saúde constante no CNES.

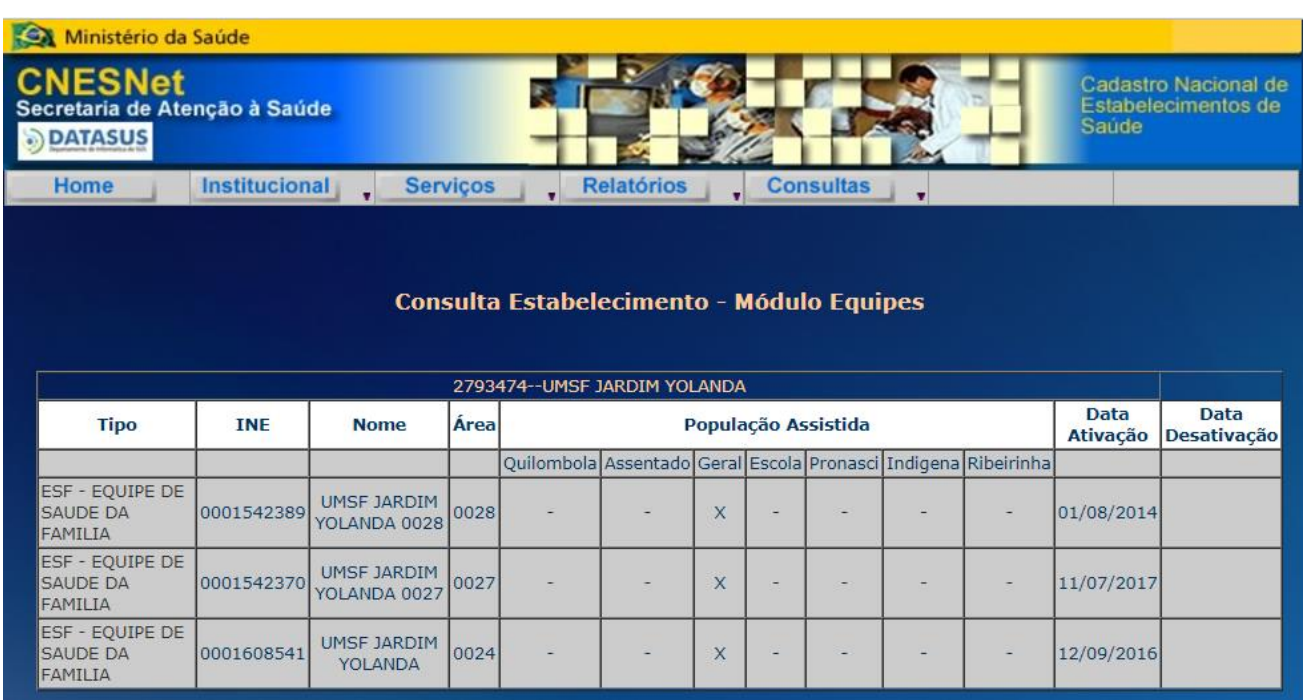

Fonte: CNES. 
A planilha resultante foi formulada em formato ".csv" contendo os campos: código CNES, unidade, equipe de saúde da família (ESF), equipe de saúde da família com saúde bucal (ESFSB), data de cadastro no CNES, data da última atualização local, data de atualização local e capacidade máxima de atendimento de pessoas (somatória do número de ESF e ESFSB multiplicado por quatro mil).

Figura 4 - Planilha síntese dos cadastros dos estabelecimentos de saúde constantes no CNES.

\begin{tabular}{|c|c|c|c|c|c|c|c|}
\hline \multicolumn{8}{|c|}{ PLANILHA SINTESE DO CNES } \\
\hline $\begin{array}{l}\text { Código } \\
\text { CNES }\end{array}$ & UNIDADE & ESF & ESFSB & $\begin{array}{l}\text { DATA DE CADASTRO } \\
\text { NO CNES }\end{array}$ & $\begin{array}{l}\text { DATA DA UL TIMA } \\
\text { ATUALIZAÇÃO: }\end{array}$ & $\begin{array}{c}\text { DATA DE } \\
\text { ATUALIZAÇĀO LOCAL }\end{array}$ & \begin{tabular}{|c|} 
CAPACIDADE MAXIMA \\
$\begin{array}{c}\text { DE ATENDIMIENTO SF } \\
\text { (pessoas) }\end{array}$
\end{tabular} \\
\hline 2086522 & UBS PARQUE SANTO ANTONIO & 0 & 0 & $23 / 06 / 2004$ & 16/09/2017 & 14/09/2017 & 0 \\
\hline 2084988 & UBS SANTA CRUZ DOS LAZAROS ANA LUISA PINHEIRO & 0 & 0 & $11 / 03 / 2003$ & 16/09/2017 & 15/09/2017 & 0 \\
\hline 2085003 & UBS SANTO ANTONIO DA BOA VISTA & 1 & 1 & $23 / 06 / 2004$ & 16/09/2017 & 23/06/2017 & 8000 \\
\hline 2026155 & UMSF BANDEIRA BRANCA & 2 & 0 & $01 / 07 / 2003$ & 16/09/2017 & 10/08/2017 & 8000 \\
\hline 2084996 & UMSF CIDADE SALVADOR & 5 & 0 & $11 / 03 / 2003$ & 16/09/2017 & $27 / 07 / 2017$ & 20000 \\
\hline 2084945 & UMSF ESPERANCA & 1 & 2 & $11 / 03 / 2003$ & 16/09/2017 & 13/09/2017 & 12000 \\
\hline 2084953 & UMSF IGARAPES & 1 & 1 & $11 / 03 / 2003$ & 16/09/2017 & $06 / 09 / 2017$ & 8000 \\
\hline 2086530 & UMSF JARDIM DAS INDUSTRIAS & 5 & 0 & $17 / 05 / 2003$ & 16/09/2017 & 14/09/2017 & 20000 \\
\hline 2086484 & UMSF JARDIM DO VALE & 0 & 2 & $20 / 06 / 2004$ & 16/09/2017 & $06 / 09 / 2017$ & 8000 \\
\hline 7347588 & UMSF JARDIM EMILIA & 1 & 0 & $30 / 10 / 2013$ & 16/09/2017 & $30 / 06 / 2017$ & 4000 \\
\hline 7471742 & UMSF JARDIM IMPERIAL & 1 & 0 & $30 / 04 / 2014$ & $16 / 09 / 2017$ & 15/09/2017 & 4000 \\
\hline 2793474 & UMSF JARDIM YOLANDA & 3 & 0 & 15/09/2003 & 16/09/2017 & $05 / 09 / 2017$ & 12000 \\
\hline 2087065 & UMSF PAGADOR ANDRADE & 1 & 0 & $05 / 08 / 2003$ & $16 / 09 / 2017$ & $28 / 07 / 2017$ & 4000 \\
\hline 2086514 & UMSF PARQUE BRASIL & 4 & 0 & $17 / 05 / 2003$ & $16 / 09 / 2017$ & $15 / 09 / 2017$ & 16000 \\
\hline 5172780 & UMSF RIO COMPRIDO & 2 & 0 & $11 / 01 / 2007$ & $16 / 09 / 2017$ & $01 / 08 / 2017$ & 8000 \\
\hline 2086506 & UMSF SAO SILVESTRE & 0 & 2 & $17 / 05 / 2003$ & $16 / 09 / 2017$ & $26 / 04 / 2017$ & 8000 \\
\hline 2084961 & UMSF VILA ZEZE & 2 & 1 & $11 / 03 / 2003$ & 16/09/2017 & $11 / 07 / 2017$ & 12000 \\
\hline 3480879 & UNIDADE DE SAUDE PARQUE MEIA LUA & 2 & 2 & $23 / 05 / 2005$ & $16 / 09 / 2017$ & $13 / 09 / 2017$ & 16000 \\
\hline
\end{tabular}

Fonte: Elaborado pelos autores.

Após esta síntese de informações, utilizou-se a ferramenta "união de tabela de atributos" tendo o atributo unidade como chave para fazer com que o shapefile de territórios de saúde obtenha as informações desta planilha.

Ao final deste processo, criou-se um novo campo no shapefile de territórios de saúde denominado "Status" e aplicou-se na calculadora de campo a regra demonstrada na Figura 5. Assim foi obtido o status de conformidade das unidades de saúde da família perante a Política Nacional de Atenção Básica, relacionando a Estimativa de População Total com a Capacidade Máxima de Atendimento.

Figura 5 - Regra aplicada para a determinação de Status de conformidade das unidades de saúde.

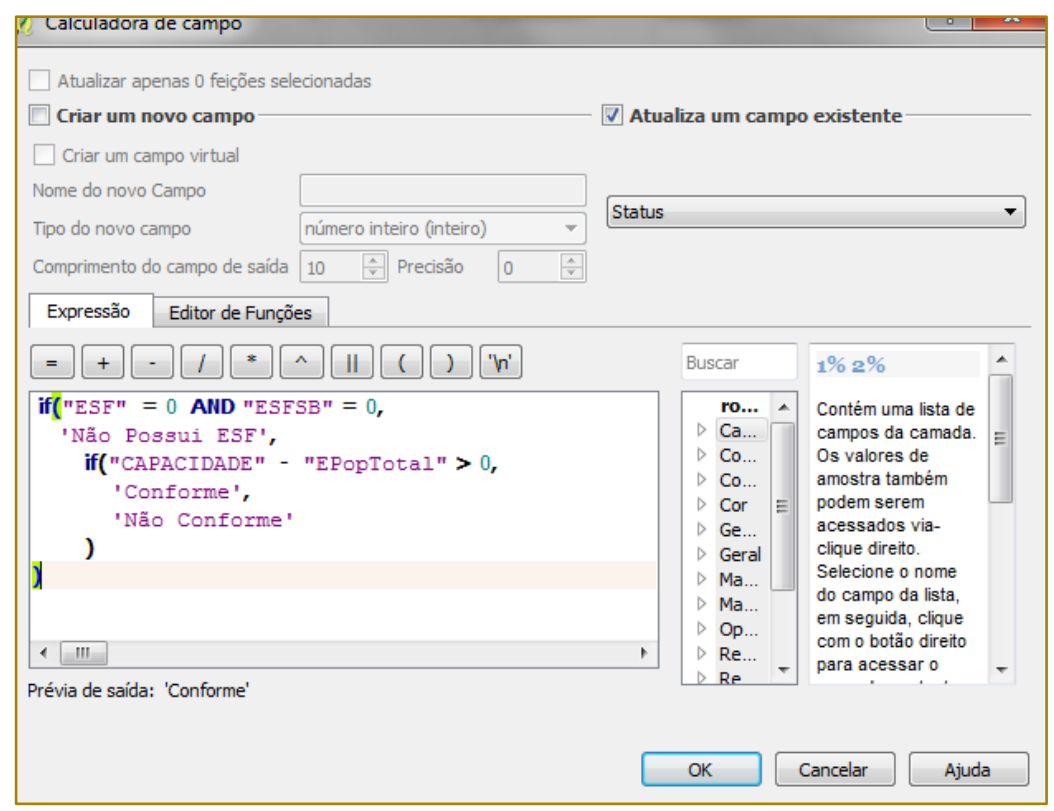

Fonte: Elaborado pelos autores. 


\subsection{FIXAÇÃO DO CONCEITO DE SUS-} DEPENDÊNCIA

O conceito de SUS-Dependência é caracterizado pela massa populacional que não possui cobertura de saúde privada. A partir disto, este conceito é encontrado na literatura tanto sendo um aspecto positivo devido à não vinculação aos planos e seguros de saúde, quanto um aspecto negativo por se relacionar àqueles indivíduos que possuem acesso à atenção à saúde somente por meio dos serviços públicos de saúde, remetendo à exclusão social.

Dado este conceito, a determinação de regiões de maior dependência do SUS levou em consideração a densidade média relativa do número de moradores em domicílios particulares permanentes que recebem até 1 salário mínimo. Esta variável foi obtida pela seguinte fórmula:

$$
\mathrm{DMR}=\left\{\left[(\mathrm{V} 05+\mathrm{V} 06+\mathrm{V} 07+\mathrm{V} 08)^{\star} \mathrm{V} 03\right] /\left(\mathrm{V} 01^{\star} \mathrm{V} 03\right)\right\}^{*} 100
$$

Onde:

DMR: Variável de densidade média relativa do número de moradores em domicílios particulares permanentes que recebem até 1 salário mínimo;

V01: Domicílios particulares permanentes ou pessoas responsáveis por domicílios particulares permanentes;

V03: Média do número de moradores em domicílios particulares permanentes;

V05: Domicílios particulares com rendimento nominal mensal domiciliar per capita de até 1/8 salário mínimo;

V06: Domicílios particulares com rendimento nominal mensal domiciliar per capita de mais de 1/8 a 1/4 salário mínimo;

V07: Domicílios particulares com rendimento nominal mensal domiciliar per capita de mais de 1/4 a 1/2 salário mínimo;

V08: Domicílios particulares com rendimento nominal mensal domiciliar per capita de mais de 1/2 a 1 salário mínimo.

A partir deste conceito fixado, criou-se um novo campo denominado "DMR" no shapefile de pontos representantes dos setores censitários obtido anteriormente na Estimativa de População Total Atendida.

Todas as variáveis utilizadas para o cálculo da DMR foram tiradas da base de informações por setor censitário referente ao censo de 2010 realizado pelo IBGE, sendo as variáveis V01 e V03 encontradas na planilha "Basico_SP2" e as restantes encontradas na planilha "DomicílioRenda_SP2".

\subsection{SUPERFÍCIE DE DISPERSÃO DA SUS- DEPENDÊNCIA}

Tendo como ponto inicial um conjunto de observações que estabelecem uma amostra, a geoestatística objetiva caracterizar espacialmente determinada variável de interesse através de sua distribuição e variabilidades espaciais, determinando as incertezas agregadas (YAMAMOTO; LANDIM,
2015). Para a devida caracterização da distribuição e variabilidade de uma variável no espaço, são utilizados métodos de interpolação. Estes métodos permitem chegar na aproximação de um novo conjunto de dados a partir de um conjunto de dados amostrais conhecidos.

Dado que o universo amostral deste estudo é constituído por setores censitários do município de Jacareí e devido ao método de amostragem ter sido realizado automaticamente pelo processo de pontos representantes na superfície de polígonos, constituiu-se uma amostragem sistemática. Porém, as coordenadas amostradas são dependentes das dimensões e localidades dos polígonos de setores censitários, assim fazendo com que a amostragem também possua características de uma amostragem aleatória simples (YAMAMOTO; LANDIM, 2015).

A partir destas informações, a determinação da Superfície de Dispersão da SUS- 
Dependência foi realizada através da utilização do método de interpolação IDW (Inverse Distance Weighted).

\subsubsection{INTERPOLAÇÃO IDW}

A técnica de interpolação IDW está entre as técnicas mais utilizadas para interpolar pontos espalhado no espaço, determinando os valores dos pontos desconhecidos através de uma combinação linear ponderada dos pontos amostrados, sendo que o peso de determinado ponto é o inverso de uma função da distância. Para o devido cálculo desta técnica de interpolação, é utilizado a seguinte fórmula (MARCUZZO; ANDRADE; MELO 2011):

$$
Z(x)=\frac{\sum_{i=1}^{n} \omega_{i} Z\left(x_{i}\right)}{\omega_{i}}
$$

Onde:

$Z(x)$ : Valor do ponto desconhecido objeto da interpolação;

n: Número de pontos espacialmente próximos utilizados na interpolação de $Z(x)$;

Z(xi): Valor do ponto conhecido;

wi: é o peso do valor do ponto conhecido sobre o ponto desconhecido. desconhecido $(x)$ objeto da interpolação, utiliza-se a seguinte fórmula:

Para determinar qual é o peso (wi) que o ponto conhecido (xi) exerce sobre o ponto

Onde:

$$
\omega_{i}=\frac{1}{h\left(x, x_{i}\right)^{p}}
$$

$h(x, x i)$ : Distância entre o ponto desconhecido e o ponto conhecido:

p: Parâmetro de potência, normalmente $h(x, x i)$ é elevado ao quadrado.

Normalmente $\mathrm{h}(\mathrm{x}, \mathrm{xi})$ é elevado ao quadrado. Porém, para adequar os valores dos pesos, parâmetro de potência maiores são utilizados para pontos mais próximos enquanto parâmetros de potência menores são aplicados aos pontos mais distantes. É válido ressaltar que esta variação no parâmetro de potência apesar de balancear os valores dos pesos, acaba tornando estes valores menos precisos (MARCUZZO; ANDRADE; MELO 2011).

\subsubsection{DETERMINAÇÃO DA SUPERFÍCIE DE DISPERSÃO DA SUS-DEPENDÊNCIA ATRAVÉS DA INTERPOLAÇÃO IDW}

Assim como a Estimativa de População Total Atendida, o SIG utilizado para realizar a interpolação IDW foi o QGIS. A partir do universo amostral definido (shapefile gerado pelo processo de pontos representantes na superfície dos polígonos de setores censitários, contendo a variável de densidade média relativa do número de moradores em domicílios particulares permanentes que recebem até hum salário mínimo), utilizou-se o plugin nativo "Interpolação" com as configurações ilustradas na Figura 6. 
Figura 6 - Configurações para interpolação IDW no QGIS.

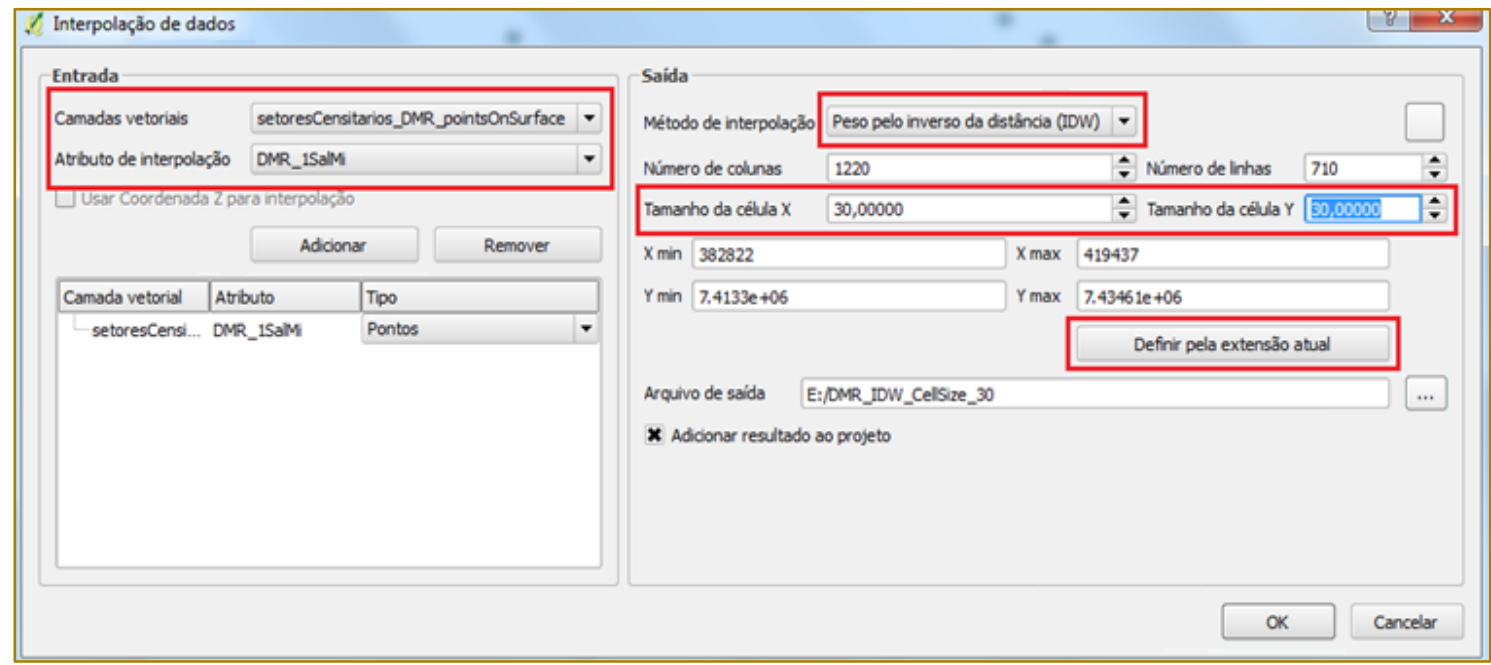

Fonte: Elaborado pelos autores.

\section{RESULTADOS E DISCUSSÃO}

A metodologia proposta permitiu a obtenção de informações úteis e críticas sobre a atenção básica a saúde do município de Jacareí.

Levando em consideração a Determinação de Conformidades das Unidades de Saúde da Família perante a Política Nacional de Atenção básica, das 17 unidades que possuem seus territórios mapeados, estimouse que sete destas não estão em conformidade com a legislação em relação ao número de equipes necessárias para devido atendimento da população. Outras oito unidades apresentaram devida conformidade, ou seja, possuem equipes o suficiente para atender seus territórios e, outras duas, não possuem a estratégia de saúde da família.

É válido constatar que a unidade Jardim Imperial se encontra contida no CNES, mas não está devidamente mapeada conforme o dado fonte dos territórios e unidades, assim estando presente somente na planilha síntese (Figura 7) não no dado resultante.

Figura 7 - Dado produto da Determinação do Status de Conformidade das Unidades de Saúde.

\begin{tabular}{|c|c|c|c|c|c|c|c|c|c|c|c|}
\hline & Nome & EPopTotal & $\begin{array}{l}\text { Codigo } \\
\text { CNE }\end{array}$ & ESF & ESFSB & DATA DE CA & DATA DAUL & DATA DE AT & CAPACIDADE & Cap_X_EPop & Status \\
\hline 1 & UMSF JARDIM YOLANDA & 8713 & 2793474 & 3 & 0 & $15 / 09 / 2003$ & $16 / 09 / 2017$ & 05/09/2017 & 12000 & 3287 & Conforme \\
\hline 2 & UBS SANTO ANTONIO DA BOA VISTA & 5044 & 2085003 & 1 & 1 & $23 / 06 / 2004$ & $16 / 09 / 2017$ & $23 / 06 / 2017$ & 8000 & 2956 & Conforme \\
\hline 3 & UMSF RIO COMPRIDO & 6183 & 5172780 & 2 & 0 & $11 / 01 / 2007$ & $16 / 09 / 2017$ & $01 / 08 / 2017$ & 8000 & 1817 & Conforme \\
\hline 4 & UNIDADE DE SAUDE PARQUE MEIA LUA & 11274 & 3480879 & 2 & 2 & $23 / 05 / 2005$ & $16 / 09 / 2017$ & $13 / 09 / 2017$ & 16000 & 4726 & Conforme \\
\hline 5 & UMSF PAGADOR ANDRADE & 3040 & 2087065 & 1 & 0 & $05 / 08 / 2003$ & $16 / 09 / 2017$ & $28 / 07 / 2017$ & 4000 & 960 & Conforme \\
\hline 6 & UMSF CIDADE SALVADOR & 16554 & 2084996 & 5 & 0 & $11 / 03 / 2003$ & $16 / 09 / 2017$ & $27 / 07 / 2017$ & 20000 & 3446 & Conforme \\
\hline 7 & UMSF SAO SILVESTRE & 5462 & 2086506 & 0 & 2 & $17 / 05 / 2003$ & $16 / 09 / 2017$ & 26/04/2017 & 8000 & 2538 & Conforme \\
\hline 8 & UMSF BANDEIRA BRANCA & 7987 & 2026155 & 2 & 0 & $01 / 07 / 2003$ & $16 / 09 / 2017$ & $10 / 08 / 2017$ & 8000 & 13 & Conforme \\
\hline 9 & UMSF JARDIM DO VALE & 10217 & 2086484 & 0 & 2 & $20 / 06 / 2004$ & $16 / 09 / 2017$ & 06/09/2017 & 8000 & $-2217 \mid$ & Não Conforme \\
\hline 10 & UMSF IGARAPES & 11593 & 2084953 & 1 & 1 & $11 / 03 / 2003$ & $16 / 09 / 2017$ & 06/09/2017 & 8000 & 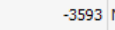 & Não Conforme \\
\hline 11 & UMSF PARQUE BRASIL & 18016 & 2086514 & 4 & 0 & $17 / 05 / 2003$ & $16 / 09 / 2017$ & $15 / 09 / 2017$ & 16000 & $-2016 I$ & Não Conforme \\
\hline 12 & UMSF JARDIM EMILIA & 8971 & 7347588 & 1 & 0 & $30 / 10 / 2013$ & $16 / 09 / 2017$ & $30 / 06 / 2017$ & 4000 & -4971 & Não Conforme \\
\hline 13 & UMSF VILA ZEZE & 12675 & 2084961 & 2 & 1 & $11 / 03 / 2003$ & $16 / 09 / 2017$ & $11 / 07 / 2017$ & 12000 & -675 & Não Conforme \\
\hline 14 & UMSF JARDIM DAS INDUSTRIAS & 21790 & 2086530 & 5 & 0 & $17 / 05 / 2003$ & $16 / 09 / 2017$ & 14/09/2017 & 20000 & -1790 & Não Conforme \\
\hline 15 & UMSF ESPERANCA & 15407 & 2084945 & 1 & 2 & $11 / 03 / 2003$ & 16/09/2017 & $13 / 09 / 2017$ & 12000 & $-3407 \mid$ & Não Conforme \\
\hline 16 & UBS PARQUE SANTO ANTONIO & 28325 & 2086522 & 0 & 0 & $23 / 06 / 2004$ & $16 / 09 / 2017$ & 14/09/2017 & 0 & -28325 & Não Possui ESF \\
\hline 17 & UBS SANTA CRUZ DOS LAZAROS ANA LUISA PINHEIRO & 19615 & 2084988 & 0 & 0 & $11 / 03 / 2003$ & $16 / 09 / 2017$ & $15 / 09 / 2017$ & 0 & -19615 & Não Possui ESF \\
\hline
\end{tabular}

Fonte: Elaborado pelos autores. 
Este "Status" de conformidade das unidades foi obtido através da correlação entre a capacidade máxima de atendimento versus a estimativa de população total e, tal estimativa, engloba todos aqueles que são dependentes do SUS junto com os que não são SUSdependentes.

Assim, para a devida comparação entre o status dos territórios de saúde com a superfície de SUS-dependência, estimou-se as regiões de maior SUS-dependência no município de Jacareí através da dispersão da variável de densidade média relativa de pessoas que recebem até um salário mínimo.

Tal dispersão foi determinada através do método de interpolação IDW e o resultado é apresentado na Figura 7. O método IDW determinou um produto com efeito "bull'seyes" na região central. Esse efeito é de ocorrência comum nos produtos resultantes da aplicação do método IDW.

Figura 7 - Dispersão da DMR produto da interpolação IDW comparada ao status de conformidade dos territórios das unidades de saúde.

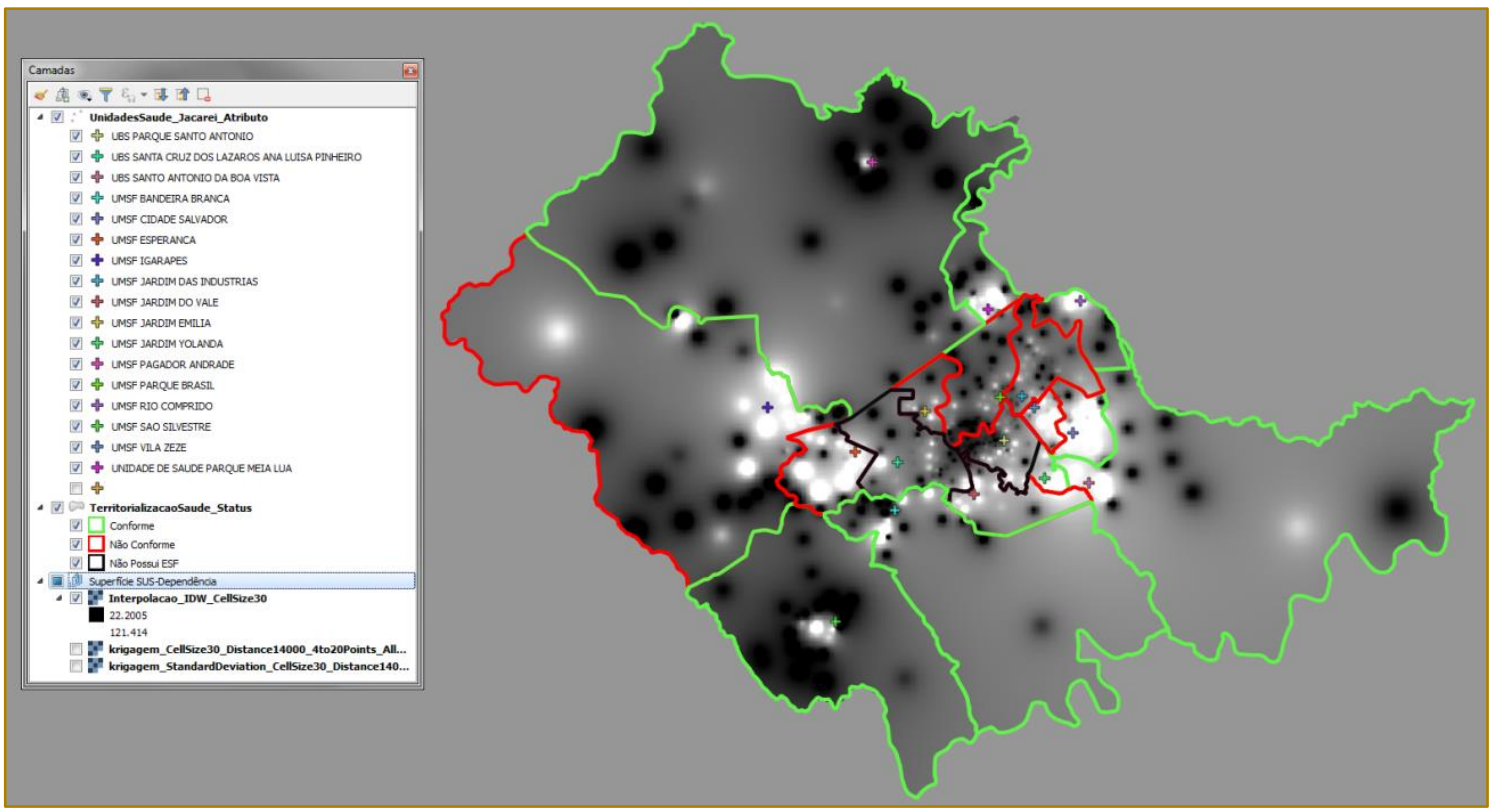

Fonte: Produzido pelos autores.

Ao analisar as superfícies de dispersão em ambos os métodos de interpolação junto com as conformidades dos territórios de saúde, percebe-se que pontos críticos são encontrados nas unidades Jardim do Vale, Jardim Emília, Igarapés, Esperança e Vila Zezé pois além de não estarem em conformidade perante a Política Nacional de Atenção Básica, estão em regiões de moderada e alta SUS-Dependência.

Ressalta-se que apesar das unidades que não possuem a estratégia saúde da família (Parque Santo Antônio e Santa Cruz dos Lázaros) se encontrarem em regiões de baixa SUS-dependência, estas são responsáveis por grande densidade populacional.

\section{CONSIDERAÇÕES FINAIS}

Executou-se neste trabalho um estudo que demonstra a utilidade e o baixo custo do uso de do geoprocessamento e da geoestatística na gestão da saúde municipal. Ressalta-se que o objetivo do trabalho foi atingido ao correlacionar o "status" de conformidade das unidades versus a superfície de SUSdependência. Como oportunidade de melhoria, sugere-se a determinação de novas superfícies de SUS-dependência através de outras técnicas geoestatísticas como a Krigagem. 


\section{REFERÊNCIAS}

[1]. BRASIL. MINISTÉRIO DA SAÚDE. Portaria no 2.488, de 21 de outubro de 2011. Aprova a Política Nacional de Atenção Básica, estabelecendo a revisão de diretrizes e normas para a organização da Atenção Básica, para a Estratégia Saúde da Família (ESF) e o Programa de Agentes Comunitários de Saúde (PACS). Diário Oficial da República Federativa do Brasil, 2011.

[2]. BRASIL. MINISTÉRIO DA SAÚDE. SECRETARIA EXECUTIVA. SUS princípios e conquistas. Ministério da Saúde, 2000.

[3]. BRASIL. Constituição da República Federativa do Brasil. Brasília: Senado Federal, 1988.

[4]. BRASIL, Casa Civil. Lei no 8.080, de 19 de setembro de 1990. Dispõe sobre as condições para a promoção, proteção e recuperação da saúde, a organização e o funcionamento dos serviços correspondentes e dá outras providências. Diário Oficial da união, v. 20, 1990.

[5]. CNES - CADASTRO NACIAL DE ESTABELECIMENTOS DE SAÚDE. Indicadores Tipo de Estabelecimento. Disponível em: < http://cnes2.datasus.gov.br/Mod_Ind_Unidade_List ar.asp?VTipo $=02 \&$ VListar $=1 \&$ VEstado $=35 \&$ VMun $=$ $352440 \& V S u b U n i=\& V C o m p=>$. Acesso em: 30 nov. 2017

[6]. IBGE - INSTITUTO BRASILEIRO DE GEOGRAFIA E ESTATÍSTICA. Downloads Estatísticas e Geociências. Disponível em: $<$ https://downloads.ibge.gov.br>. Acesso em: 20 nov. 2017.
[7]. MARCUZZO, Francisco Fernando Noronha; ANDRADE, Lucas Reinehr; MELO, Denise Christina de Rezende (2011). Métodos de interpolação matemática no mapeamento de chuvas do estado do Mato Grosso. Revista Brasileira de Geografia Física, v. 04, p. 793-804.

[8]. QGIS - QUANTUM GEOGRAPHIC INFORMATION SYSTEM. Descubra O QGIS. Disponível em: <http://www.qgis.org/pt_BR/site/about/index.html>. Acesso em: 22 nov. 2017.

[9]. QUINELLATO, Luciano Vasconcellos. A diretriz de hierarquização do SUS: mudando a antiga perspectiva do modelo médico-assistencial privatista. 2009. Tese de Doutorado.

[10]. SANTOS, Nelson Rodrigues dos. SUS, política pública de Estado: seu desenvolvimento instituído e instituinte e a busca de saídas. Ciência \& saúde coletiva, v. 18, n. 1, 2013.

[11]. SOUZA, Celina. Políticas públicas: uma revisão da literatura. 2006. UNIVERSIDADE FEDERAL DA INTEGRAÇÃO LATINO-AMERICANA. Programa de Pós-Graduação em Políticas Públicas e Desenvolvimento.

[12]. WORLD HEALTH ORGANIZATION et al. Constitution of the world healthorganization. 1995.

[13]. YAMAMOTO, Jorge Kazuo; LANDIM, Paulo M. Barbosa. Geoestatística: conceitos e aplicações. Oficina de textos, 2015.

[14]. ZMITROWICZ, Witold; NETO, G. Angelis. Infra-estrutura urbana. São Paulo: EPUSP, 1997. 


\section{Capítulo 16}

\section{TECNOLOGIA ASSISTIVA: DESENVOLVIMENTO DE SOFTWARE PARA AUXILIAR NA COMUNICAÇÃO DE CRIANÇAS COM O ESPECTRO AUTISTA}

\section{Lucas de Figueiredo José}

Paulo Victor Homem de Mello Kusplica

Cristiane Marisa dos Santos

Alexandre Garcia de Oliveira

Resumo: Devido à necessidade de inclusão social de pessoas diagnosticadas com o Transtorno do Espectro Autista (TEA), o presente artigo tem o objetivo de mostrar que o aplicativo se utilizará da Tecnologia Assistiva, para auxiliar crianças, jovens e adultos não verbais a se comunicar através dos PECS. Para tanto, foram realizadas visitas em instituições especializadas no assunto e estudo bibliográfico minucioso acerca do Transtorno do Espectro Autista a fim de elencar os requisitos indispensáveis para a edificação e validação da aplicação. Para o seu desenvolvimento foi utilizado o ambiente web responsivo, assim como técnicas de prototipagem e elicitação de requisitos.

Palavras-chave: Transtorno do Espectro Autista, Tecnologia Assistiva, Aplicação Web. 


\section{INTRODUÇÃO}

O presente projeto passou a despertar interesse a partir da observação acerca das dificuldades de inclusão social de pessoas portadoras do

Transtorno do Espectro Autista (TEA). Segundo Strelhow (2016), há um cálculo que no Brasil existem cerca de aproximadamente 2 milhões de pessoas acometidas com esse transtorno e na esfera mundial essa estimativa aumenta para 70 milhões. Isso comprova uma grande escala de pessoas que podem sofrer algum tipo de exclusão social.

Dentre todas as dificuldades enfrentadas, destacam-se três características que são as mais afetadas quando se tem o TEA. São elas: a interação social, a coordenação motora e a comunicação. A aplicação em desenvolvimento enfatiza a parte da comunicação, como uma maneira de inserção dos autistas no meio social. Facilitando assim, amenizar os obstáculos enfrentados e garantindo as mesmas oportunidades das demais pessoas.

A aplicação tem por finalidade, auxiliar pais, professores, cuidadores e demais envolvidos a criar um elo com o indivíduo, assim como interagir com o mesmo, além de aperfeiçoar e valorizar a comunicação social utilizando, para isso, de Tecnologias Assistivas (TA), visando oferecer uma autonomia as pessoas portadoras de TEA, baseado no sistema de comunicação por meio da troca de imagens das rotinas cotidianas (PECS). Segundo Melo (2016) os PECS colaboram para que a pessoa com TEA compreenda que através das imagens ela pode se comunicar com outras pessoas e conseguir expressar o que quer, sendo assim entendida e atendida de forma mais rápida, garantindo a elas poder de escolha, satisfação, autonomia e segurança.

\section{EMBASAMENTO TEÓRICO}

\subsection{TRANSTORNO DO ESPECTRO AUTISTA}

A expressão autismo foi usada pela primeira vez por Eugen Bleuler (1857-1939), psiquiatra suíço contemporâneo a Freud e membro da Sociedade Psicanalítica de Viena, em 1911, para nomear um grupo de sintomas que se relacionavam à esquizofrenia, tais como, a perda de contato com a realidade, o que acarretava uma grande dificuldade ou impossibilidade de comunicação.
$\mathrm{Na}$ década de 40, mais precisamente em 1944, Dr. Leo Kanner, psiquiatra austríaco, radicado nos Estados Unidos e diretor de psiquiatria infantil do Johns Hopkins Hospital, publicou a obra "Distúrbios Autísticos do Contato Afetivo". Descrevendo nela onze casos de crianças que possuíam em comum o que o autor intitulou "isolamento extremo desde o início da vida e um desejo obsessivo pela preservação da mesmice, denominandoas autistas" e usou o termo "autismo infantil precoce", pois os sintomas já apareciam na primeira infância.

Kranner revelou ao mundo seus estudos que indicavam como diagnosticar o TEA, com base em alguns aspectos, tais como: dificuldades apresentadas em atividades rotineiras, limitações no contato afetivo, interesse obsessivo por objetos ou temas específicos, competência acima do normal para memorização mecânica, habilidades motoras limitadas, isolamento, dificuldade de concentração e na obtenção do aprendizado (STRELHOW, 2016).

Cerca de um ano depois, o Hans Asperger, psiquiatra e pesquisador austríaco, escreveu um artigo, intitulado de "Psicopatologia Autística da Infância", ao qual descrevia o comportamento de crianças, que eram semelhantes às condutas enfatizadas por Kanner. Ambos os autores são reconhecidos mundialmente, pois, através de suas obras foi possível identificar características inerentes a crianças com autismo (MELLO, 2016).

Com o final da segunda guerra mundial, muitos combatentes tornaram- se deficientes. Após muitos estudos e um trabalho de reabilitação eficiente, voltaram a produzir e em favor deles, foi surgindo uma legião multidisciplinar de defensores de seus direitos. Eram cidadãos que se sentiam, de algum modo, responsáveis pelos soldados que tinham ido representar a pátria no front, há décadas. Apesar de dano e perdas, o saldo foi positivo. O mundo começou a acreditar na capacidade das pessoas com deficiência.

$\mathrm{Na}$ defesa da inclusão Werneck enfatiza a construção de uma sociedade inclusiva que estabeleça um compromisso com as minorias, dentre as quais se inserem os indivíduos que apresentam necessidades educacionais especiais. A autora salienta que a inclusão vem "quebrar barreiras cristalizadas em torno de grandes estigmatizados" (1997, p. 45). Na concepção de Sassaki: 
É fundamental equiparmos as oportunidades para que todas as pessoas, incluindo portadoras de deficiência, possam ter acesso a todos os serviços, bens, ambientes construídos e ambientes naturais, em busca da realização de seus sonhos e objetivos (SASSAKI, 2002, p. 41).

Em 1952, a Associação Americana de Psiquiatria publica a primeira edição do Manual Diagnóstico e Estatístico de Doenças Mentais (DSM-1), esse manual fornece nomenclaturas e critérios padrões para o diagnóstico de transtorno mental. Em sua primeira edição, os sintomas autísticos eram classificados como um subgrupo da esquizofrenia. O Autismo não era considerado como um diagnóstico separado.

Desde 2013, o Manual de Diagnóstico e Estatístico de Transtornos Mentais (DSM-5) trouxe uma nova classificação dentro de Transtornos do Neurodesenvolvimento: o Transtorno do Espectro Autista (TEA). Isso significa que o quadro engloba Autismo, Síndrome de Asperger, Síndrome de Rett, Transtornos do desenvolvimento e Transtorno Desintegrativo da Infância.

\subsection{SISTEMAS DE COMUNICAÇÃO ATRAVÉS DE IMAGENS}

O método consiste em uma intervenção aumentativa/alternativa de comunicação principalmente para pessoas com transtorno do espectro do autismo e doenças do desenvolvimento relacionadas. Sendo um sistema mundialmente reconhecido, este método utiliza-se do uso de imagens a fim de auxiliar na comunicação entre portadores de TEA e as pessoas que o cercam.

Para implementação do PECS é de grande importância considerar uma sequência de seis etapas fundamentais. São elas:

Fase I: Como se comunicar, o indivíduo aprende a trocar uma única imagem por itens ou atividades que ele realmente queira.

Fase II: Distância e Persistência, com o uso de apenas uma imagem, o indivíduo aprende a generalizar esta nova habilidade e usá-la em lugares distintos, com pessoas diferentes e usando distâncias variadas. Desta forma, ensina-se a se comunicar de forma persistente.

Fase III: Discriminação de imagens, o indivíduo aprende a escolher entre duas ou mais imagens a fim de pedir seus itens favoritos.

Fase IV: Estrutura de sentença, o indivíduo aprende a construir frases simples como por exemplo, "eu quero", seguido de uma imagem do item que está sendo solicitado.

Fase V: Respondendo perguntas, o indivíduo aprende a usar PECS para responder perguntas como: "O que você quer?".

Fase VI: Comentando, nesta fase, o indivíduo aprende a comentar em resposta a perguntas como: "O que é isso?". Aprendendo assim a compor sentenças como: "eu vejo", "eu ouço", etc.

Para Walter (2000), o cenário é voltado para a realidade brasileira, sendo expostas imagens do cotidiano, como por exemplo, lavar as mãos, hora de comer, hora de tomar banho, hora de escovar os dentes, etc. De modo geral, PECS são de fácil ajustamento, custo relativamente baixo e não necessita de treinamento específico para a sua utilização, o que o torna altamente eficaz, tanto social como economicamente, na inclusão de pessoas diagnosticadas com TEA.

\subsection{TECNOLOGIA ASSISTIVA}

De acordo com BARBOSA e SILVA, 2011 as Tecnologias Assistivas contribuíram para evidenciar a interação homem computador a fim de aumentar significantemente as relações no ambiente sócio-cultural, como também minimizar as limitações de pessoas com distúrbios físicos e/ou de aprendizagem (AVILAR; PASSERINO e TAUROCO; 2013).

Segundo o Comitê de Ajudas Técnicas (BRASIL, 2009), "a TA é uma área do conhecimento, de característica interdisciplinar, cujo objetivo é promover a funcionalidade relacionada à atividade e participação de pessoas com deficiência, visando um aumento da autonomia, independência, qualidade de vida e inclusão social".

Com base na diversidade de possibilidades de TA, o presente projeto se enfatizará na a categoria de comunicação aumentativa e alternativa, utilizando- se, singularmente, das PECS. 


\section{DESENVOLVIMENTO DA TEMÁTICA}

\subsection{METODOLOGIA}

Atualmente existe maior liberdade ao se falar de metodologia de desenvolvimento de softwares. Por conta da competitividade do mercado, cada vez mais vão surgindo novas ferramentas e novos métodos com o objetivo de auxiliar o avanço e o aperfeiçoamento de uma nova tecnologia, independentemente de sua plataforma de origem.

De acordo com Corral, Sillitti e Succi (2012), essa multiplicidade representa um desafio para os desenvolvedores de software. Contudo, desenvolver um software independe para cada plataforma, requer que o ciclo de vida do software seja executado várias vezes, para cada aplicação liberada, fazendo assim, que esse processo se torne redundante $e$ caro. Para selecionar as ferramentas é importante, primeiramente, definir qual tipo de tecnologia deverá ser utilizada durante o desenvolvimento: para averiguar se a aplicação será nativa ou se usará tecnologias web (sites móveis).

Corral L, Sillitti A e Succi G. (2012) demonstram em um estudo onde foram observados que em sete (7) de oito (8) testes de rotinas de avaliação de desempenho, as tecnologias web se mostraram mais lentas que as nativas.

Por serem otimizados para o sistema operacional, aplicativos nativos podem ofertar uma experiência mais agradável ao usuário, e também garante a capacidade de comunicação com os dispositivos do aparelho, como câmera, GPS, entre outros. Isso gera uma aplicação mais abrangente.

Considerando os pontos apresentados e ainda a experiência da equipe de desenvolvimento, optou-se por desenvolver uma aplicação web para desktop e dispositivos móveis. A aplicação será desenvolvida em ambiente configurado com tecnologias livres.

\subsection{ELICITAÇÃO DOS REQUISITOS}

Todo procedimento de construção de software, tem como atividade fundamental a elicitação e a documentação de requisitos. A elicitação de requisitos é denominada como um conjunto de técnicas de levantamento de dados, com o objetivo de elucidar as necessidades dos Stakeholders. É a escalação e aplicação correta dessas técnicas, que definem o sucesso ou fracasso de um projeto de software.

Conforme Hickey e Davis (2003), as técnicas de elicitação têm por finalidade identificar os requisitos conscientes, inconscientes e subconscientes dos Stakeholders. Os autores ressaltam que não existe exclusivamente um método universal para realizar esse processo.

Como enfatiza Pohl e Rupp (2011) as técnicas de pesquisa têm como objetivo elicitar as necessidades precisas e imparciais dos stakeholders, e cita o questionário e a entrevista como as técnicas mais utilizadas.

O questionário, como o próprio nome sugere, possui uma série de questões abertas e/ou fechadas que possibilitam a coleta de informações em grandes quantidades de stakeholders e num curto espaço de tempo. $\mathrm{O}$ uso isolado desta técnica se torna coerente nos casos em que a equipe já tenha um conhecimento aprofundado das necessidades do público alvo do sistema.

As perguntas na entrevista são previamente acentuadas e as respostas são documentadas. Esta técnica se torna essencial quando a equipe de desenvolvimento não possui conhecimento das necessidades dos usuários, podendo ser utilizada para coletar uma grande quantidade de detalhes que não seriam obtidas unicamente pelo uso de outras técnicas.

Há também, a técnica da etnografia, que visa observar e compreender requisitos sociais e organizacionais de um grupo de pessoas, detalhando assim, algumas particularidades que outras técnicas não conseguem atingir satisfatoriamente.

Dentre as mais diversas técnicas de elicitação existentes, a prototipagem é bastante difundida, como sendo uma maneira de auxiliar os stakeholders na coleta de requisitos, e será discutida na próxima seção.

Segundo Braude e Bernstein (2010), a prototipagem faz parte de um conjunto de técnicas da engenharia de requisitos, que tem como finalidade tratar de problemas de relacionamento humano que podem vir a aparecer entre desenvolvedores e usuários, quando se trata de definição de requisitos, sendo importante para se obter ideias sobre as necessidades dos clientes. Sua aplicação minimiza o tempo gasto na coleta de requisitos, promovendo também uma participação ativa de todas as partes interessadas. 


\subsection{DESENVOLVIMENTO}

Para desenvolver a aplicação, foram realizadas visitas de reconhecimento das necessidades reais de pessoas com TEA em Centros especializados no assunto, assim como com profissionais da área e das técnicas de elicitação de requisitos, baseadas na triangulação, que usa paralelamente diversas técnicas, dentre elas, a etnografia, a prototipagem e as entrevistas.

A triangulação é uma estratégia de utilizar mais do que uma técnica de coleta ou análise de dados para obter diferentes perspectivas e confirmar as descobertas, permitindo obter resultados mais rigorosos e válidos (BARBOSA e SILVA, 2011, p.133).

Para tanto, será feito um levantamento de dados demográficos, experiência com computadores, expectativas de usuários, e tarefas, tipo: "em quais tipos de tarefas o usuário precisa de apoio? Quais dessas tarefas são consideradas primárias? Quais são secundárias? Há quanto tempo realiza estas tarefas? São frequentes ou não? São inovadoras? Que experiência ele possui em tarefas semelhantes?" (BARBOSA e SILVA, 2011). Justapondo a metodologia de prototipagem evolutiva, a equipe disponibilizará um protótipo primitivo do

Foto 1 - Tarefas diárias

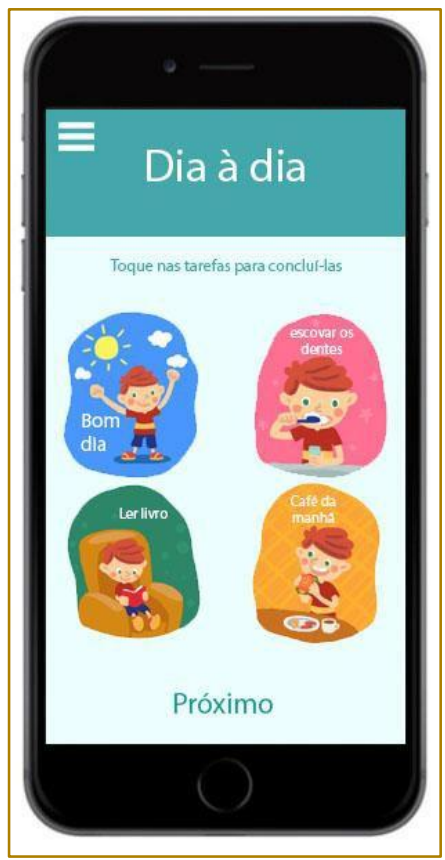

sistema, com as funcionalidades reduzidas, tendo como objetivo, analisar se as decisões tomadas até o presente momento são de fato eficazes e o que precisa ser melhorado para que somente então, esse protótipo seja aprimorado e finalmente chegue ao produto completo com todas as funcionalidades almejadas para o usuário portador do Transtorno.

\section{RESULTADOS E DISCUSSÃO}

De posse de todos os aspectos apresentados aqui, as aspirações são direcionadas para que a partir da abordagem dos conceitos e técnicas de elicitação de requisitos, assim como a aplicação de protótipos e todos os conhecimentos obtidos no estudo de caso, seja possível obter todas as informações pertinentes para se elaborar um software completo, que auxilie pessoas portadoras do TEA a estimular e desenvolver suas habilidades cognitivas e de comunicação.

Para o desenvolvimento da aplicação deve-se manter atenção no que é realmente necessário para, de forma efetiva, auxiliar na comunicação e no dia à dia de pessoas portadoras do TEA, levando em conta sua idade para que o ambiente da aplicação mude conforme a necessidade.
Foto 2 - Tarefas noturnas

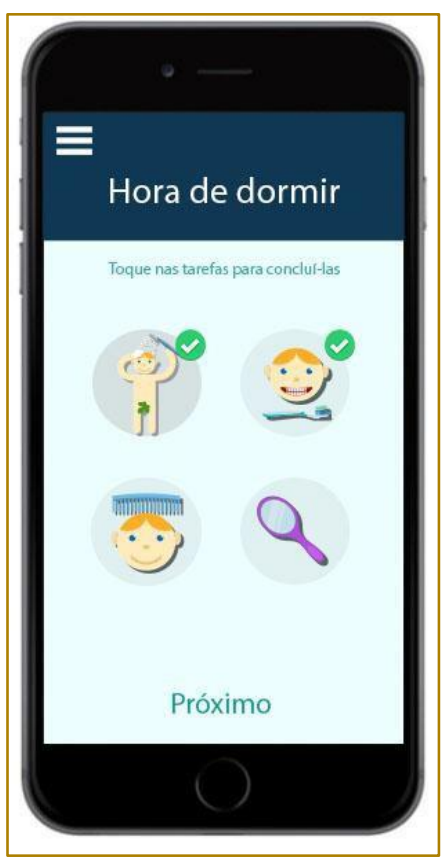

Fonte: Elaborado pelo autor 
Referente ao layout das tarefas do dia à dia entre outros, pode-se configurar a rotina de acordo com o perfil de cada usuário. As rotinas são um passo à passo de tarefas obrigatórias ou não que o portador do TEA segue para facilitar a execução de suas atividades cotidianas.

\section{CONSIDERAÇÕES FINAIS}

Após entrevistas com pais e responsáveis por pessoas portadoras do TEA e pesquisas bibliográficas, foi possível levantar os problemas e trazer soluções reais para o cenário em questão.

Com o uso de tecnologia de ponta $e$ metodologias assistivas, foi elaborado um protótipo que simula a aplicação em questão

\section{REFERÊNCIAS}

[1]. American Psychiatric Association. (1994). DSM IV: Manual diagnóstico e estatístico de distúrbios mentais. São Paulo: Artes Médicas.

[2]. Avilar, B. G.; Passerino, L. M., e Tarouco, L. M. R (2013). "Usabilidade em tecnologia assistiva: estudo de caso num sistema de comunicação alternativa para crianças com autismo", In Revista Latinoamericana de Tecnologia Educativa (RELATEC), v. 12, p. 115129.

[3]. Basílio da Silva, L. L.; Pires, D. F. e Carvalho Neto, S. (2015), "Desenvolvimento de Aplicações para Dispositivos Móveis: Tipos e Exemplo de Aplicação na plataforma iOS", II Workshop de Iniciação Científica em Sistemas de Informação. Goiânia - GO, 26 a 29 de maio de 2015.

[4]. Barbosa, S. D. J. e SILVA, B. S.(2011) "Interação Humano-Computador", Rio de Janeiro: ELSEVIER

[5]. Brasil. Subsecretaria Nacional de Promoção dos Direitos da Pessoa com Deficiência (2009), "Tecnologia Assistiva", Brasília: CORDE.

[6]. Braude, E. J. and Bernstein, M. E. (2010) "Software Engineering: modern approaches", 2.ed. Waveland Press: Apr 5 2010, 800 p. contendo uma prévia de algumas das possíveis funcionalidades que a aplicação web pode trazer para auxiliar a vida de pessoas portadoras do TEA. Uma das funcionalidades abordadas a ser estudada é um sistema baseado em conquistas, no qual o usuário tem a liberdade de executar alguns tipos de tarefas sociais quando estiver confortável, desde que isso não atrapalhe em suas atividades cotidianas.

Conclui-se que a aplicação em si pode auxiliar de forma eficaz aos usuários em questão a organizar as informações sobre a rotina diária de forma integrada, visualmente organizada e clara, propiciando aprendizados e colaborando para o desenvolvimento e viabilizar uma comunicação alternativa para crianças, adolescentes e adultos que ainda não têm total domínio da comunicação verbal.

[7]. Corral, L.; Sillitti, A. andSucci, G. (2012), "Mobile multiplatformdevelopment: Anexperiment for performance analysis", in Procedia Computer Science, v. 10, p. 736743.

[8]. Hickey, A. M. and Davis, A. M. (2003), "ElicitationTechniqueSelection: How Do Experts Do It?"inProceedingsofthe 11th IEEE InternationalRequirementsEngineeringConference.

[9]. Pohl, K. andRupp, C. (2011) "RequirementsEngineering Fundamentals: A StudyGuide for theCertified Professional for RequirementsEngineeringExam", Santa Barbara: RockyNook.

[10]. Mello, A. M. S. R. (2016) "Autismo: guia prático", 8aㅡ ed., São Paulo: AMA

[11]. SASSAKI, Romeu Kazumi. Inclusão: construindo uma sociedade para todos. 4 ed. Rio de Janeiro: WVA, 2002

[12]. Strelhow, T. M. P. B. (2016) "Autismo e Cotidiano: Um Olhar para as Experiências Familiares", Jundiaí: Paco Editorial.

[13]. Walter, C. C. F. (2000) "Efeitos da Adaptação do PECS Associada ao Curriculum Funcional Natural em Pessoas com Autismo Infantil”, In Dissertação - UFSCAR - São Carlos. 


\section{Capítulo 17}

\section{ESTUDOS DOS CICLOS OPERACIONAIS E FINANCEIROS DO SETOR AUTOMOBILISTICO}

\section{Patrícia Gonçalves Pinto}

\section{Sara Silva Duarte}

\section{Vinicius Carvalho Fernandes Assis}

\section{Lucineide Bispo dos Reis Luz}

Resumo: Esta pesquisa trabalho tem o objetivo de avaliar os índices: Ciclo operacional, ciclo financeiro, prazo médio de pagamento, prazo médio de recebimento e o prazo médio de estoque. Apurados a partir das empresas que atuam no setor automobilístico, Metal Leve; Plascar e lochp-Maxion. A fim de atender a problemática: As empresas que atuam no mercado setor automobilístico apresentam os ciclos operacionais semelhantes? Para atingir o objetivo deste trabalho utilizamos como base os resultados apurados pela empresa Economatica no período de 2016. O resultado da pesquisa foi que a empresa Plascar, obteve melhores índices dentro dos padrões da área automobilística, principalmente o ciclo operacional.

Palavras-chave: Ciclo Operacional. Ciclo Financeiro. Prazo médio de Pagamento. Prazo Médio de Recebimento. Prazo Médio de Estoque. 


\section{INTRODUÇÃO}

A evolução da indústria automobilística no mercado, foi enfatizada pelas diversas e intensas modificações decorrentes de invenções na fabricação de automóveis. A cada novo modelo de veículo que aparecia ocasionava alterações nas estratégias de montagem e organização do trabalho nas indústrias e, simultaneamente, novas ideias se espalhavam para os demais setores que por muitas vezes as ajustavam e mudavam a forma da produção dos bens.

O Brasil tornou-se uma peça fundamental do mecanismo industrial global. O Brasil é $8^{\circ}$ maior produtor mundial de veículos. Na frente estão China, Estados Unidos, Japão, Alemanha, Coréia do Sul, Índia e México, segundo o boletim de inteligência SEBRAE 2015. As questões econômicas não devem ser esquecidas, precisamos de uma nova política para a redistribuição de renda, o desenvolvimento do país e uma estratégia de melhoria na estabilidade econômica. São pontos que contribuem para o progresso das industrias.

Por meados do século xx, o Brasil não era um país independente, ele ainda era ligado ao setor da agricultura, em teor econômico; na década 30 do mesmo século, subsequente a revolução, Getúlio Vargas incorporou novas medidas para a políticas e políticas sociais que facilitariam o desenvolvimento de indústrias dentro do país. No início o Brasil apenas montava os carros, nada era de produção nacional. Veículos eram trazidos desmontados e as fabricas tinha o trabalho de juntar cada parte que pertencia aos automóveis e ônibus. A primeira montadora que tivemos foi a Grassi, que já montava carroceiras de ônibus desde 1908.

Os dois nomes americanos de maior importância que tínhamos na época eram, a Ford desde 1919 no Brasil e a GM que chegou no país por volta de 1925, ambos adotaram o mesmo processo produtivo, fase de montadoras de automóveis. Após a Segunda Guerra Mundial, o Brasil passou a importar automóveis, naquela data a inflação contribuía para tornar os produtos ainda mais interessantes, considerando foi o período que o país mais investiu em automóveis, ao invés de petróleo e trigo, produtos que também eram importados, contudo para a incorporação das indústrias automobilísticas no pais era de precisão os investimentos voltados para os maquinários e matérias primas diversas, principalmente para criar meios de produção de energia elétricas, mesmo quando o governo restringiu a importação dos veículos.

O objetivo desta pesquisa é discutir os índices de Prazo médio de pagamento (PMP); Prazo médio de recebimento (PMR); Przo médio de estoque (PME); Ciclo operacional (CO) e Ciclo fincanceiro (CF) do subsetor de automóveis e motocicletas no ano de 2016. As três maiores empresas do ramo são as Metal Leve; Plascar e lochp-Maxion, objeto do nossos estudos.

O trabalho foi realizado com base nos dados da Bovespa, divulgados pela Economatica em 2016.

O presente trabalho está estruturado da seguinte forma: Introdução, revisão bibliográfica, metodologia, apresentação dos dados estudados e discussão.

\section{EMBASAMENTO TEÓRICO OU REVISÃO DA LITERATURA}

A análise financeira de balanços é essencial para transmitir a seus usuários informações da empresa.

Dante Carmine Matarazzo (2010), em seu livro: Análise Financeira de Balanços, Abordagem Gerencial (p. 2) diz que a análise de balanços objetiva extrair informações das demonstrações financeiras para tomada de decisões.

Diversos usuários estão interessados em pontos especificos em que a análise das demonstrações financeiras poderá fornecer, tudo irá depender de suas necessidades.

A análise de balanços permite uma visão da estratégia e dos planos da empresa analisada, permite estimar o seu futuro, suas limitações e suas potencialidades. É de primordial importância, para todos os que pretendam relacionar-se com uma empresa, quer como fornecedores, financiadores, acionistas e até empregados. (Matarazzo, Dante Carmine, 2010, p. 15)

Dando ênfase na importância da análise financeira das demonstrações contábeis, em seu livro "Análise das Demonstrações Contábeis", José Carlos Marion (2010) divide a análise das demonstrações em três níveis: introdutório, intermerdiário e avançado. 
No nível introdutório, Marion diz que alguns indicadores básicos são utilizados.

Poderíamos dizer que só teremos condições de conhecer a situação econômico-financeira de uma empresa por meio dos três pontos fundamentais de análise:

- $\quad$ Liquidez, que demonstra a situação financeira;

Rentabilidade, que demonstra a
situação econômica; e
- Endvidamento, que demonstra a
estrutura no capital.

(Marion, José Carlos, 2010, p. 1)

No nível intermediário, Marion (2010) utiliza-se da base do nível introdutório, chamando-o de tripé (liquidez-rentabilidade-endividamento) e afirna que para obter mais informações deverão ser utilizados outro conjunto de indicadores para demonstrar a seus usuários a situação econômico-financeira da empresa.

Os indicadores não são exclusivos para obter informações específicas de cada unidade do tripé. Por exemplo: a análise da DOAR (Demonstrações das Origens e Aplicações de Recursos - não é mais uma demonstração obrigatória) propicia informações relevantes não só do endividamento, mas também da situação financeira (liquidez). A DFC (Demonstração dos Fluxos de Caixa) também traz subsidios no que se refere a situação financeira (liquidez). (Marion, José Carlos, 2010, p.3)

No nível avançado da análise, Marion (2010) diz "que uma série de outros indicadores e instrumentos de análise enriqueceriam ainda mais as conclusões referentes à situação econômico-financeira de uma empresa". Em seu livro, nos apresenta outras ferramentas para análise do tripé, não esgotando assim as fontes de informações.

Com diversos índices existentes, nosso foco está em apresentar os índices que a própria empresa analisa através de suas demonstrações.

São eles:

- Prazo Médio de Recebimento de Vendas

Fórmula utilizada: Duplicatas a receber/Nendas $\times 360$

- Prazo Médio de Compras

Fórmula utilizada: Fornecedor/Compras x 360
- Prazo Médio de Renovação de Estoques

Fórmula utilizada: Estoque/Custo da mercadoria da vendida $\times 360$

- Ciclo Operacional

Fórmula utilizada: Prazo médio de renovação de estoques + Prazo médio de recebimento de vendas

- Ciclo Financeiro

Fórmula utilizada: Ciclo Operacional - Prazo médio de pagamento

\section{DESENVOLVIMENTO DA TEMÁTICA}

A revisão bibliográfica é necessária para o pesquisador aprender sobre o tema do qual está desenvolvendo, é a fonte de pesquisa feita em livros, periódicos, internet, de um ou mais autores. Segundo Marconi e Lakos (2010), a revisão bibliográfica não é apenas reprodução do que o autor escreveu e sim uma oportunidade em criar novas conclusões.

No trabalho cientifico, demonstra o conhecimento dos autores (estudiosos) que possam ou não ter a mesma opinião sobre a ciência analisada.

Para Bastos, Paixão, Fernandes e Deluiz (2010), a revisão bibliográfica consiste na fundamentação da problematização, dos objetivos do tema de estudo, das hipóteses. Também ela evita que o autor não faça repetição dos estudos já realizados, que o autor se familiarize com o objeto de estudo e procedimentos metodológicos adotados em outras pesquisas e de formar o conceito para interpretação dos resultados do estudo.

Este trabalho tem abordagem qualitativa, que para o autor Pedro Demo tem como importância compreender a problemática e ir além das avaliações quantitativas habituais.

\section{RESULTADOS E DISCUSSÃO}

Cada grupo de stakeholders tem um determinado índice de analise onde detém um maior interesse. Ou seja, o investidor está atento normalmente aos índices de liquidez e endividamento, para saber a rentabilidade da companhia. Sendo assim, sabendo se este irá conseguir ter uma segurança e um bom retorno. Já os fornecedores normalmente visam índices que mostram a capacidade de pagamento da empresa, e os clientes procurando sempre ver os prazos de estoque 
para saber se a empresa terá condições de atendê-los.

Foram selecionadas três empresas do ramo de automóveis e motocicletas conforme dados de 31 de dezembro de 2016, conforme Gráfico número 1:

Gráfico 1 - Demonstrativo de índices corporativos:

\begin{tabular}{|c|c|c|c|c|c|c|c|c|}
\hline Nome & Código & Subsetor Bovespa & $\begin{array}{l}\text { Data do } \\
\text { Último } \\
\text { Balanço }\end{array}$ & $\begin{array}{r}\text { Prazo } \\
\text { Médio } \\
\text { Estoques } \\
\text { em di }^{\nabla} \\
\end{array}$ & $\begin{array}{r}\text { Prazo Médio } \\
\text { Forne ce dore } \\
\mathbf{s} \\
\text { em d }{ }^{\nabla}\end{array}$ & \begin{tabular}{|r|} 
Prazo \\
Médio \\
Re ce bimen \\
to \\
7 \\
\end{tabular} & $\begin{array}{r}\text { Ciclo } \\
\text { Financeiro } \\
\text { em dias } \\
\\
\end{array}$ & $\begin{array}{r}\text { Ciclo } \\
\text { Operacion } \\
\text { al } \\
\text { em di } \\
\end{array}$ \\
\hline lochp-Maxion & MYPK3 & Automóveis e motocicletas & $31 / 12 / 2016$ & 65 & 60 & 59 & 63 & 124 \\
\hline Metal Leve & LEVE3 & Automóveis e motocicletas & $31 / 12 / 2016$ & 72 & 34 & 68 & 106 & 140 \\
\hline Plascar Part & PLAS3 & Automóveis e motocicletas & $31 / 12 / 2016$ & 51 & 39 & 19 & 31 & 70 \\
\hline
\end{tabular}

Fonte: Economática

A empresa lochp Maxion apresenta resultados não relevantes comparados as outras, por isso, este estudo tem o objetivo de analisar os índices de atividade operacional das empresas Plascar e Metal Leve pela interpretação dos resultados apurados do Ciclo operacional, prazo médio de estocagem, prazo médio de pagamento e o prazo médio de recebimento.

Dentro do ciclo operacional conforme analisamos os índices de estocagem e recebimentos concluímos que no ciclo operacional ocorre a diferença de 70 dias por a metal leve se utilizar de instrumentos derivativos de proteção cambial e por ter itens em seu estoque de giro lento, porem o que afeta negativamente para maior o ciclo da metal leve são os itens de giro lento no estoque sendo assim a melhor decisão a ser tomada pela metal leva para melhoramento de seus resultados em estoque é a redução desses itens que tem um giro lento e tentar negociar estes um preço menor de mercado se verificarem que se encontram perto da sua obsolescência. Conforme gráfico número 2 :

Gráfico 2 - Ciclo operacional

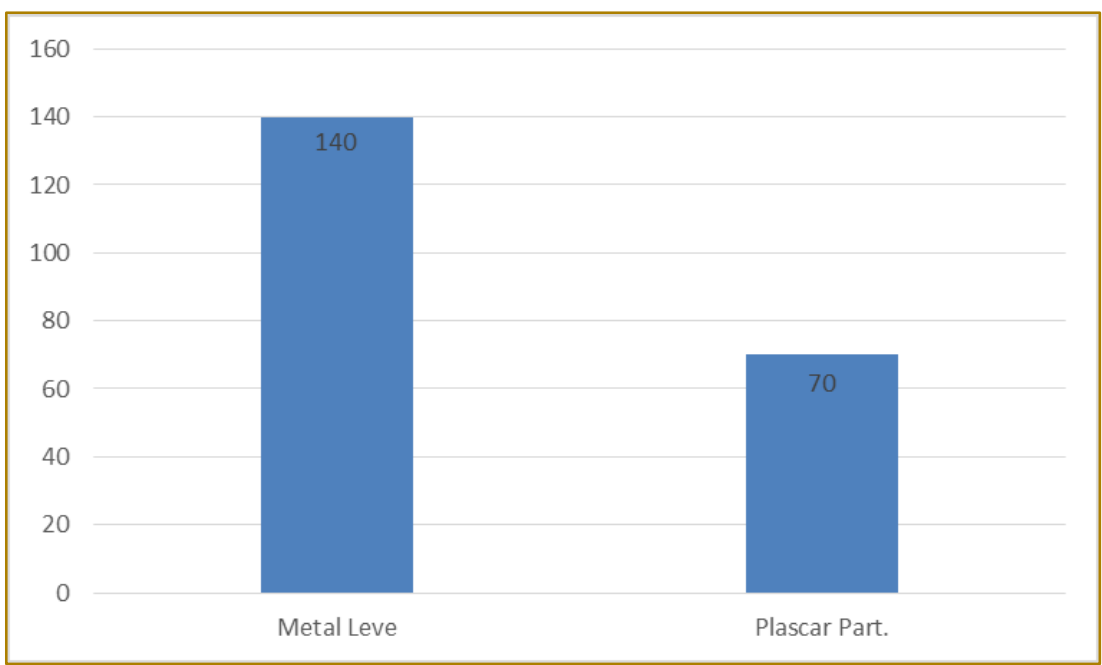

Fonte: Economática

No prazo médio de estocagem observa-se que o da Metal leve é maior em 21 dias do que o da Plascar porque dentro dos estoques da metal leve foi verificado nas suas notas explicativas de 2016 "item 10-estoques" que ela detém itens de giro lento em seu estoque, fazendo assim que por conta disso aumente esse número de dias de estocagem, e logo afetando o ciclo operacional. Já a Plascar provavelmente não detém desses itens de 
giro lento no estoque já que não foi abrangido dentro das suas notas explicativas do ano de 2016 "item 7-estoques" porém tanto a Plascar, quanto a Metal leve detém de item dedutíveis de seus estoque por obsolescência. Conforme gráfico número 3 :

\section{Gráfico 3 - Prazo médio de estocagem}

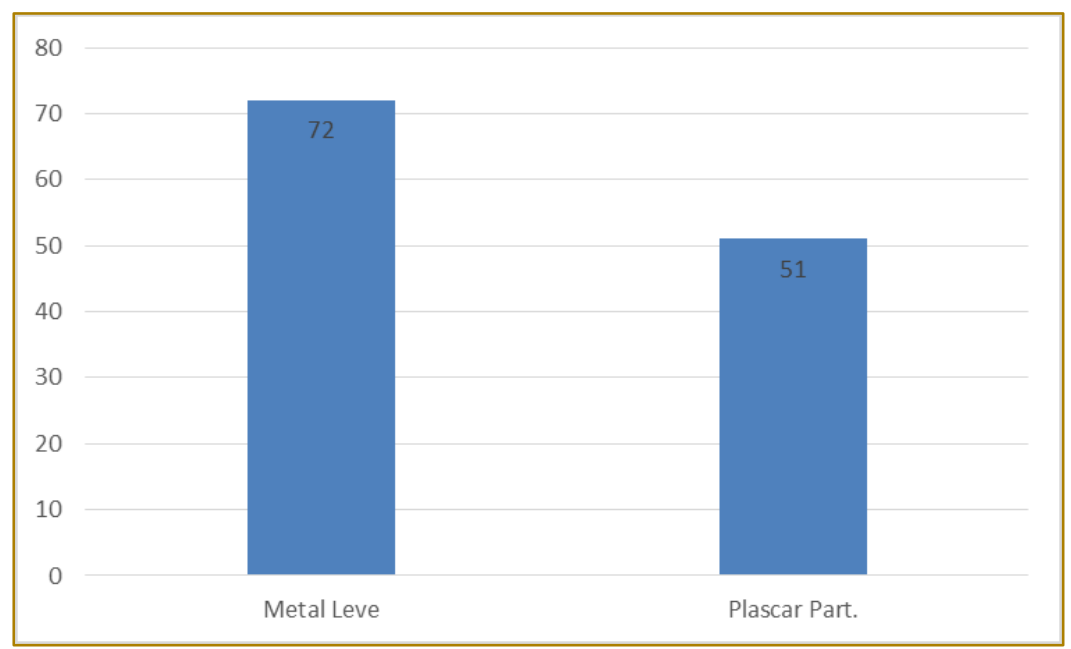

Fonte: Economática

E agora avaliando os 49 dias de diferença no prazo médio de recebimento da Metal leve para a Plascar. Notamos que por a metal leve utilizar de instrumento financeiro de hedge de fluxo caixa para proteção de seus recebíveis em moeda estrangeira conforme em nota explicativa de 2016 "viii-instrumentos financeiros derivativos", utilizando-se como proteção da variação do câmbio. Eles estão colocando os prazos de recebimento mais longos por terem um pouco dessa "segurança." Já a Plascar que não faz uso de nenhum objeto derivativo de proteção contra o câmbio de acordo com nota explicativa de 2016 "i risco cambial", negocia seus prazos com vencimentos mais curtos para tentar se proteger de uma variação mais longa e de um risco maior. Impactando assim diretamente no ciclo operacional e de caixa. Conforme gráfico número 4:

Gráfico 4 - Prazo médio de recebimento

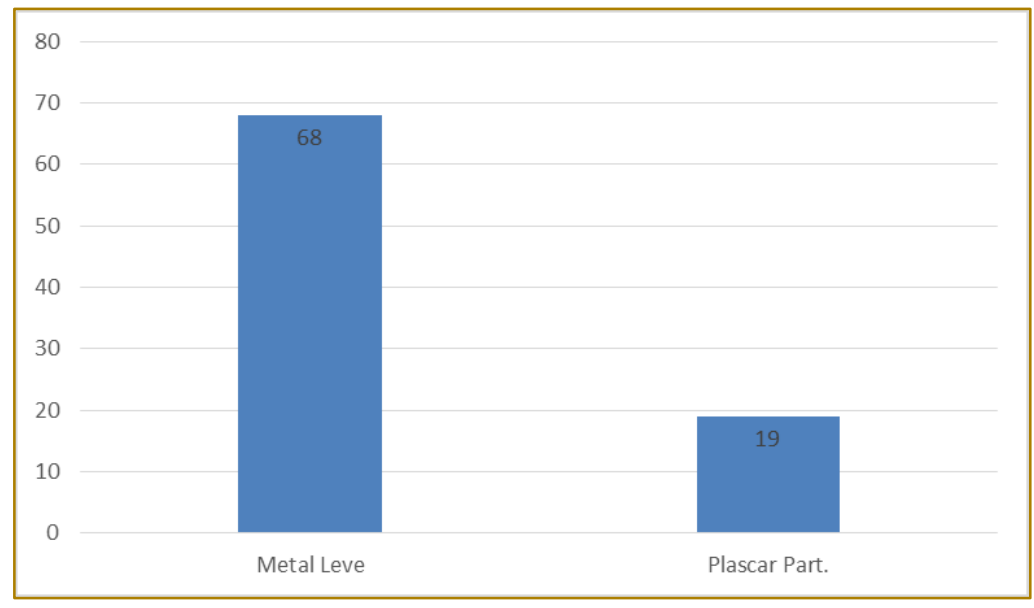

Fonte: Economática

Dentro do prazo médio de pagamento as duas companhias se mostram com os índices abaixo da média. Quando comparado ao mercado de automóveis, segundo relatório de Desempenho do setor de autopeças divulgado por Sindipeças referente a dados 
de 2016, que normalmente tem os prazos na casa dos 60 dias. Podemos analisar a Plascar e a Metal leve com um grau de incerteza frente aos fornecedores, não só pela a forte crise que afeta todo o setor automobilístico, como por mais alguns agravantes. Primeiramente citaremos a Plascar, onde a baixa liquidez que ela está tendo junto aos bancos na questão da negociação dos seus débitos e pela baixa credibilidade de novos financiamentos de fluxo de caixa impactam diretamente no grau de negociação de prazos com fornecedores, dificultando a extensão desses prazos. Já a Metal Leve, gera um certo grau de incerteza nos fornecedores, pois está desenvolvendo um novo produto que pode não ser bem aceito no mercado, como também pode ser. Ou seja, é um risco para a companhia. Todo esse cenário eleva o grau de prudência e conservadorismo por parte dos fornecedores, levando eles a tentarem colocar prazos a baixo do mercado para à venda das suas matérias primas, para essas duas companhias. Conforme gráfico número 5:

Gráfico 5 - Prazo médio de pagamento

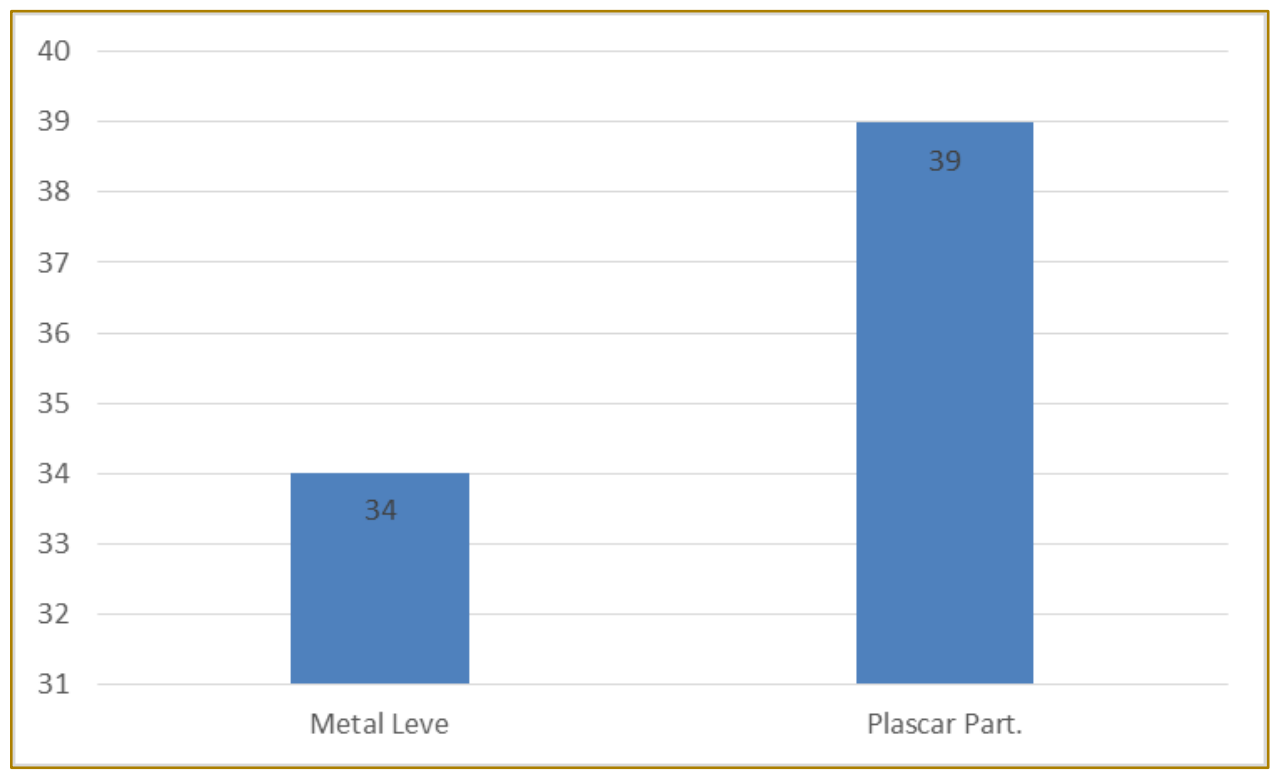

Fonte: Economática

Neste item do ciclo financeiro podemos analisar que a Metal leve demora mais para ter o retorno dos seus recursos para o caixa, devido a ter produtos de giro longo no estoque e por causa de comercializar seus produtos para o exterior com a utilização de um instrumento financeiro de hedge protegendo o seu ativo. Disponibilizando assim uma carga maior de dias para receber seus devidos valores, porém não negociando essa diferença de prazo com seus fornecedores. Levando ela a ter um furo de 34 dias da data da venda e recebimento, até o pagamento da devida matéria prima. Além do mais ela está jogada ao risco de mercado pelo desenvolvimento de um novo produto. Já a Plascar está com uma ressalva positiva. Pois está dentro da média do setor no retorno dos seus recebíveis, levando à não necessitar tanto do uso dos seus giro de caixa para financiar os processos operacionais. Conforme gráfico número 6 : 
Gráfico 6 - Ciclo financeiro

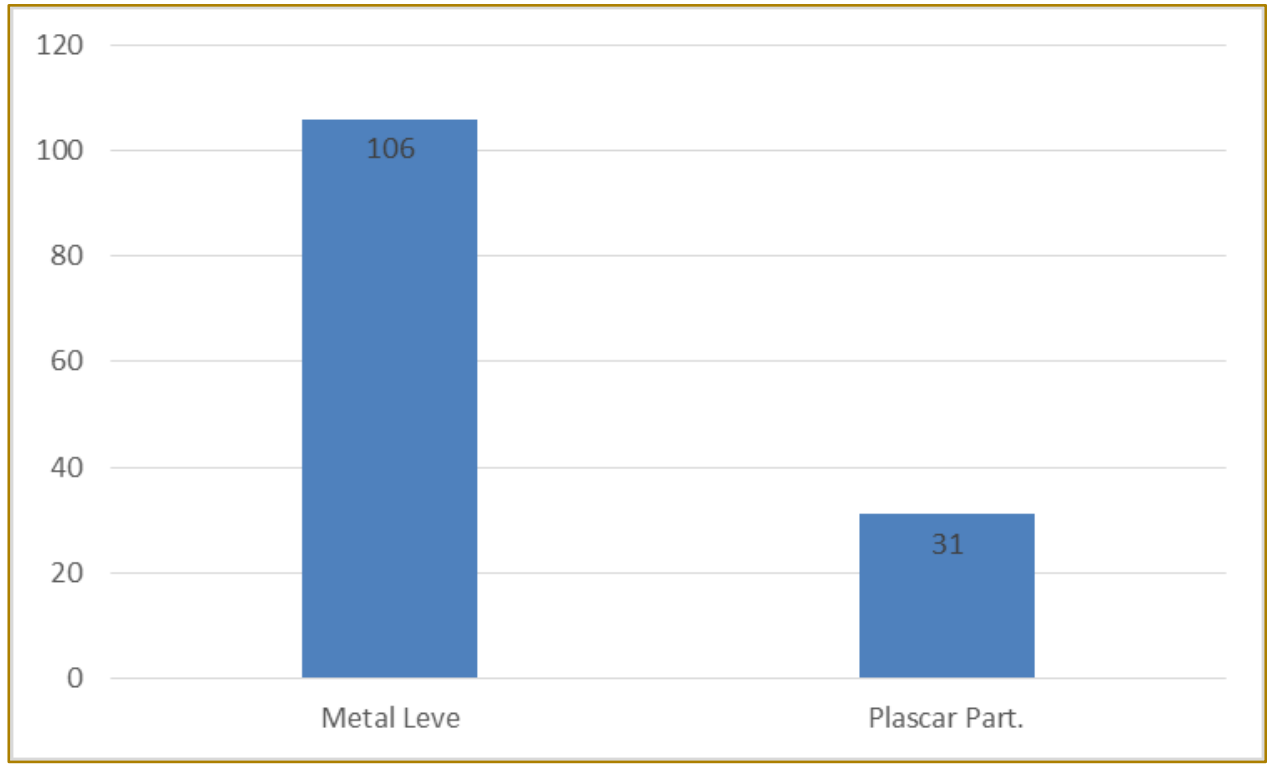

Fonte: Economática

\section{CONSIDERAÇÕES FINAIS}

A análise dos dados permitiu verificar que apesar de termos duas empresas do mesmo ramo haverá algumas divergências nas maneiras de se contabilizar determinados itens. As diferenças entre empresas deste ramo, deve se principalmente a importação de matéria prima.

Foi observado que a empresa Plascar trabalha com bons limites operacionais

\section{REFERÊNCIAS}

[1]. ELISEU MARTINS, GILBERTO JOSÉ MIRANDA, JOSEDILTON ALVES DINIZ. Analise didática das demonstrações contábeis. $2^{\underline{a}}$ ed. São Paulo/SP: Atlas, 2018.

[2]. MATARAZZO, DANTE CARMINE. Análise Financeira de Balanços. São Paulo. Editora Atlas 2010.

[3]. MARION, JOSÉ CARLOS. Análise das Demonstrações Contábeis Contabilidade Empresarial. São Paulo. Editora Atlas 2010. trazendo folga tanto na questão operacional quanto na financeira. A Metal Leve, por sua vez, tem índices mais discrepantes quando comparados aos índices da Plascar, principalmente pelo fato de apresentar prazos mais elásticos. Isso se deve ao uso de determinados instrumentos financeiros, como Hedge de Fluxo de Caixa.

Adicionalmente, a Metal Leve, pelos estudos, apresentou, deficiências no seu estoque, embora considere identificado e solucionado.

[4]. MARCONI, MARINA DE ANDRADE; LAKATOS, EVA MARIA. Técnicas de Pesquisa. São Paulo. 5a ed. Editora Atlas 2002.

[5]. Plascar Institucional http://www.plascar.com.br/2012/pt/informacoesfinanceiras/

[6]. Metal Leve Institucional http://ri.mahle.com.br/pt/documentos/1014-DFACMML-2016.pdf 


\section{Gapítulo 18}

\section{ANÁLISE DOS IMPACTOS DA IMPLANTAÇÃO DE FAIXA EXCLUSIVA PARA ONNIBUS: ESTUDO DE CASO EM UMA VIA COM FLUXO CONTÍNUO DE VEÍCULOS}

\section{Erik Massahiro Sato}

Fernando Mendes Torres

Luiz Antônio Tozi

Reinaldo Fagundes dos Santos

Resumo: A operação em vias com faixas exclusivas para ônibus busca a redução do tempo de translado de forma a atrair os usuários de transporte individual. Este artigo tem como objetivo avaliar os impactos no tempo de viagem com a implantação de uma faixa exclusiva para ônibus em uma avenida com elevado índice de fluxo de veículos na cidade de São José dos Campos. Para atingir este objetivo, foi desenvolvida uma pesquisa bibliográfica seguida de um levantamento em campo na Avenida Doutor João Guilhermino, contemplando o fluxo de veículos, intersecções semafóricas e quantidade de faixas de trânsito. Os dados coletados, em horários de pico e horários de baixo fluxo, foram analisados por meio de um modelo de simulação computacional utilizando o software Arena. Os resultados obtidos apontam para a não necessidade da faixa exclusiva para ônibus, que consome de forma exclusiva uma faixa de rolamento sem trazer nenhuma redução no tempo total do percurso.

Palavras-chave: Simulação, Trânsito, Congestionamento. 


\section{INTRODUÇÃO}

A análise do fluxo de pessoas têm sido tema corriqueiro na literatura recente sobre desenvolvimento urbano. Aos efeitos adversos resultantes do aumento de indivíduos que habitam uma região, os trabalhos de Cintra (2013) e Resende e Souza (2009) ressaltam que no Brasil há, ainda, forte cultura do automóvel particular. Desta forma, sugere-se a hipótese de que o aumento de pessoas em um centro urbano é acompanhado do aumento de veículos circulando nesse mesmo espaço (NASCIMENTO E TOZI, 2010).

Conforme Santoro e Vaz (2005) pensar em mobilidade urbana é, portanto, pensar sobre como organizar os usos e a ocupação da cidade e a melhor forma de garantir o acesso das pessoas e bens ao que a cidade oferece, e não apenas os meios de transporte e trânsito.

A mobilidade urbana torna como o principal sistema que necessita de melhorias, a priorização de tipo de transporte coletivo, como ressalta Previdelli (2013) um ônibus com cem passageiros tem direito a cem vezes mais espaço de vias do que carro com um.

Ferraz e Torres (2004) ressaltam a importância do transporte coletivo, onde possui uma junção de várias pessoas, cada com seu motivo de viagem em um mesmo veículo. Caracterizando como uma saída para vários problemas em grandes cidades, melhorando a qualidade de vida da sociedade, como diminuição de poluentes, congestionamento e acidentes de trânsito. Nesse contexto torna-se relevante citar a adoção de mecanismos que permitem o desenvolvimento do transporte coletivo. Destes, o conceito de direito de passagem (TCQSM, 1999) consiste na implantação de medidas como os corredores de ônibus e faixas exclusivas para transporte coletivo como as principais ações a serem adotadas pelo gestor público de transporte.

Diante do apresentado, este artigo tem como objetivo geral avaliar os impactos no tempo de viagem com a implantação de uma faixa exclusiva para ônibus em uma avenida com elevado índice de fluxo de veículos. Para isso, foi tomado como base de estudo um caso de implantação de faixa exclusiva de ônibus em região central do município de São José dos Campos. Por meio de um modelo de simulação computacional, foram testados cenários com e sem faixa exclusiva. Os testes foram seguidos por medições tempo de translado pela formação de filas nas faixas de rolamento e congestionamento.

\section{REVISÃO DA LITERATURA}

Neste capítulo foram pesquisados trabalhos que permitem criar as bases conceituais do tema em discussão. O foco inicial do capítulo consiste em trazer ao leitor discussões pertinentes ao tema, sistemas de transporte urbano e as vias urbanas.

\subsection{CONGESTIONAMENTOS E SEUS IMPACTOS SOCIOECONÔMICOS}

Os congestionamentos prejudicam não só a cidade, como também a qualidade de vida das pessoas, tendo como fatores resultantes a poluição sonora e do ar, o estresse gerado pelo trânsito e o tempo de viagem na locomoção de um lugar para outro. Segundo Leonardi (2015) é necessário criar cidades humanas, que tenham como objetivo criar tantas oportunidades de interação econômicas comerciais e sociais quanto possível. E, nesse aspecto, a locomoção das pessoas tem papel fundamental.

No aspecto econômico, Baima (2013) indica em seu estudo que estimar um valor monetário para o tempo perdido no trânsito é praticamente inviável. Porém, em termos de qualidade de vida, é possível se estabelecer um valor, ainda que indireto, para o tempo que as pessoas ficam presas em engarrafamentos ou perdem esperando por condução. A ideia do autor remonta ao conceito de que ao demorar menos nos seus deslocamentos, os indivíduos ganham tempo produtivo. Além disso, se gasta menos combustível para ir e voltar do trabalho, e as empresas ganham com um menor índice de atrasos e maior produtividade.

\subsection{TECNOLOGIAS DE APOIO AO TRANSPORTE COLETIVO}

A Tecnologia da Informação tem apresentado soluções para auxílio no desenvolvimento dos sistemas de transporte coletivo. Essas soluções contribuem para a eficiência no nível de serviço do transporte. Destaca-se o uso de ferramentas de comunicação onde pode ser visto em tempo real os horários, os locais atendidos, o tempo de viagem e o tempo de espera do transporte.

Sobre os sistemas de informação com base tecnológica, Silva (2000) destacou quatro 
funções principais, são elas: promocional que se refere a melhoria da imagem do transporte; a promoção dos motivos das viagens $e$ destinos, e facilidade no sistema; ensinamento relaciona a como utilizar o transporte e as regras; operacional que permite ao usuário planejar viagens e se informar de alterações na programação; e a de moderação que atua sobre o comportamento do usuário, reduzindo sua ansiedade e dando a ele controle de escolha das opções disponíveis. Ressalta-se que essas funções são pertinentes nos sistemas atuais.

Por fim, Lanzoni et al. (2011) citam que os usuários terão diferentes necessidades de utilização do transporte e os sistemas informativos devem atender a estas necessidades. Os autores enquadram que a demanda inicial pelo transporte coletivo se dá da seguinte forma:

- Usuários Regulares em rota cotidiana: precisam de informações atualizadas das linhas que usam mesmo já sendo familiarizados;

- Usuários Regulares em rota nova: conhecem o sistema, mas precisam de informação da rede de transportes e seus itinerários;

- Usuários Potenciais: precisam de informações promocionais e básicas como tarifas, horários e rotas, por entenderem pouco do sistema;

- Turistas: precisam de informações mais completas por não conhecerem o sistema local.

\subsection{FAIXAS EXCLUSIVAS}

A operação com faixas exclusivas para ônibus é um investimento com baixo custo, que possui duas vantagens. A primeira corresponde à diminuição de contato com outros veículos e a segunda é uma medida adicional que visa a redução dos atrasos em interseções e paradas.

O relatório NATO/CCMS (1976) diz o seguinte:

"parece razoável supor que, já que os ônibus normalmente carregam mais passageiros que automóveis em relação ao uso do espaço vários (muitas vezes congestionado), a eficácia do transporte público como todo seria aumentado priorizando os ônibus sobre os demais veículos."

White (1986) ressalta que os aspectos técnicos relacionados a operação de ônibus dizem respeito aos veículos em si. Porém, atacar o problema de forma sistêmica, incluindo a infraestrutura de apoio, permitiriam soluções com impacto mais significativo para o sistema. Diante disso, investimos fixos no controle, sistemas de informação e faixas reservadas a operação de ônibus poderiam render benefícios aos usuários.

Nelson e Hills (1990) afirmam que a chave para a maior eficiência da operação de ônibus parece residir na maior coordenação entre ônibus e passageiros. Isso implicaria maior controle sobre os ônibus que entram no corredor e progressão deles ao longo da via, e maior informação por parte dos passageiros de onde aguardar um determinado ônibus que atenda a seus destinos.

\section{APRESENTAÇÃO DO CENÁRIO EM ESTUDO}

O estudo foi realizado na forma de uma pesquisa de campo coletando dados de acordo com tempo de semáforos e a quantidade de veículos que passavam por uma intersecção semafórica escolhida próxima a um ponto de ônibus.

A avenida, apresentada na Figura 1, possui 680 metros de comprimento, contêm 3 faixas de veículos, com largura de 3,00 metros cada, e uma faixa do corredor destinada para ônibus. A velocidade máxima da via é de 50 $\mathrm{km} / \mathrm{hora}$. 
Figura 1 - Avenida Doutor João Guilhermino

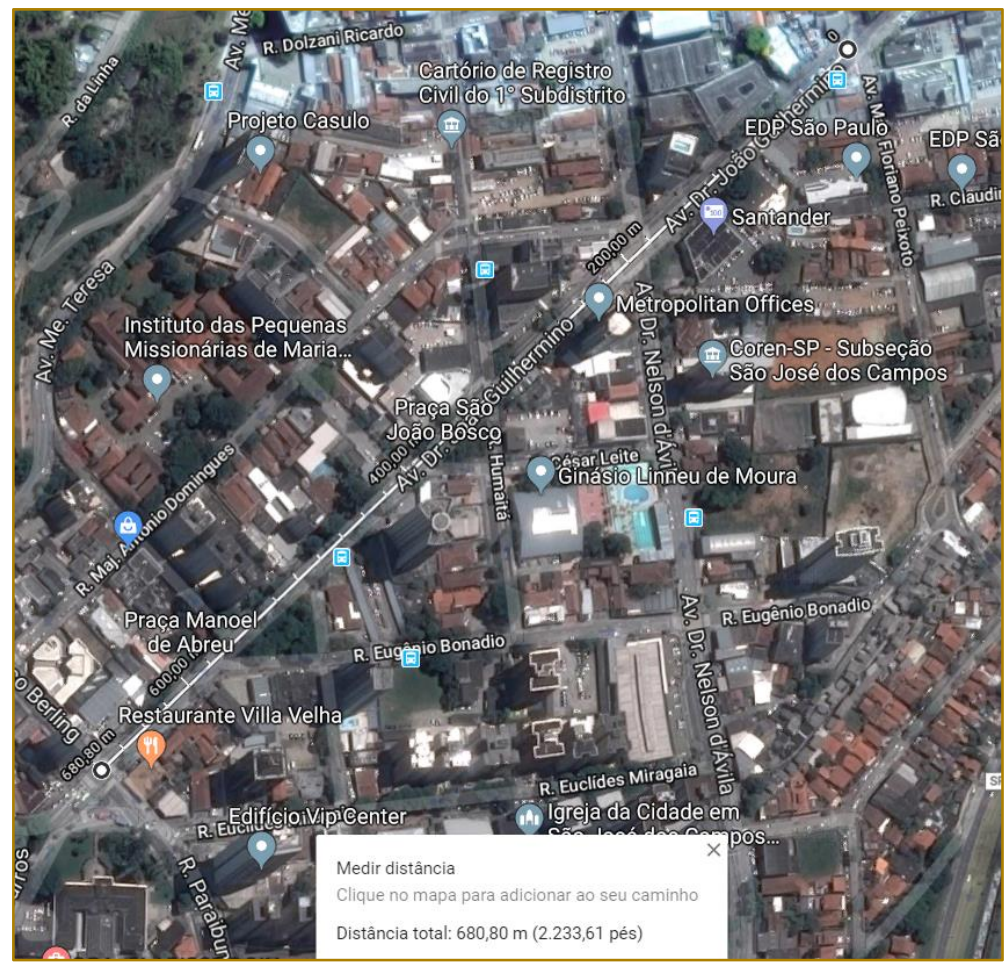

Fonte: Google/Maps (2018)

A Figura 2 apresenta detalhe visual da avenida.

Figura 2 - Faixa de ônibus

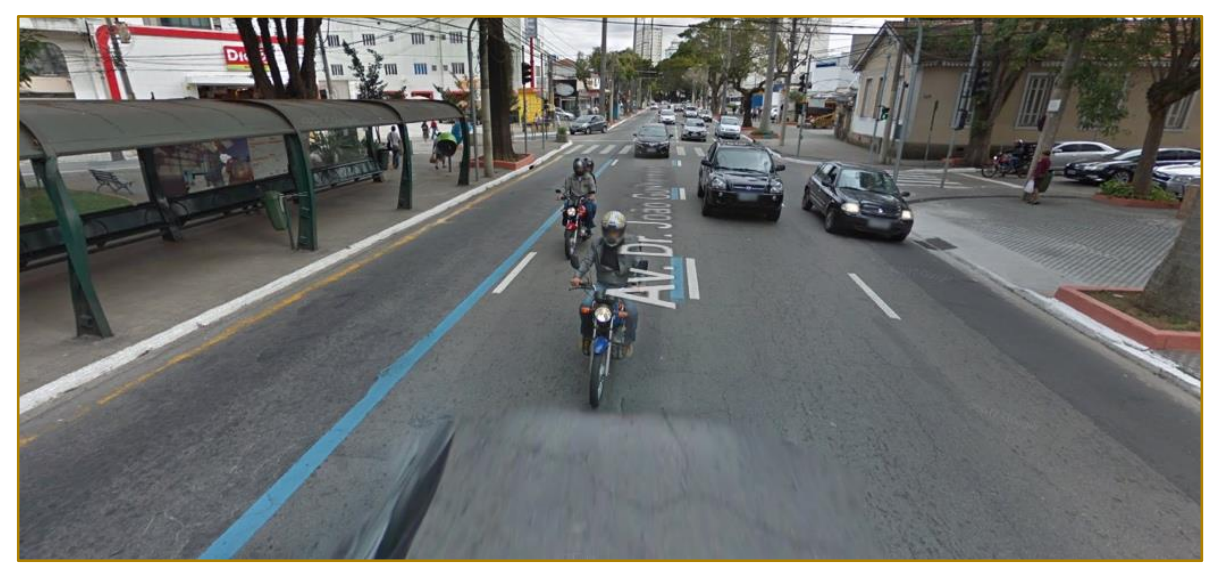

Fonte: Google/Maps (2018)

\section{APLICAÇÃO DO MODELO DE SIMULAÇÃO}

O sistema de trânsito da avenida foi modelado de quatro formas no programa Arena. Para demonstrar os sistemas de trânsito, foram considerados um modelo na hora de pico e um fora da hora de pico. As duas primeiras formas representam 0 contexto real da via. A via possui, atualmente, 3 faixas de veículos e 1 faixa exclusiva de ônibus. Na terceira e quarta formas, também foram analisados os cenários de hora de pico e fora de hora de pico, porém foram consideradas as 4 faixas para veículos. A Figura 3 representa o esquema com exemplo de um dos modelos rodados. 
Figura 3 - Exemplo do Modelo em Arena

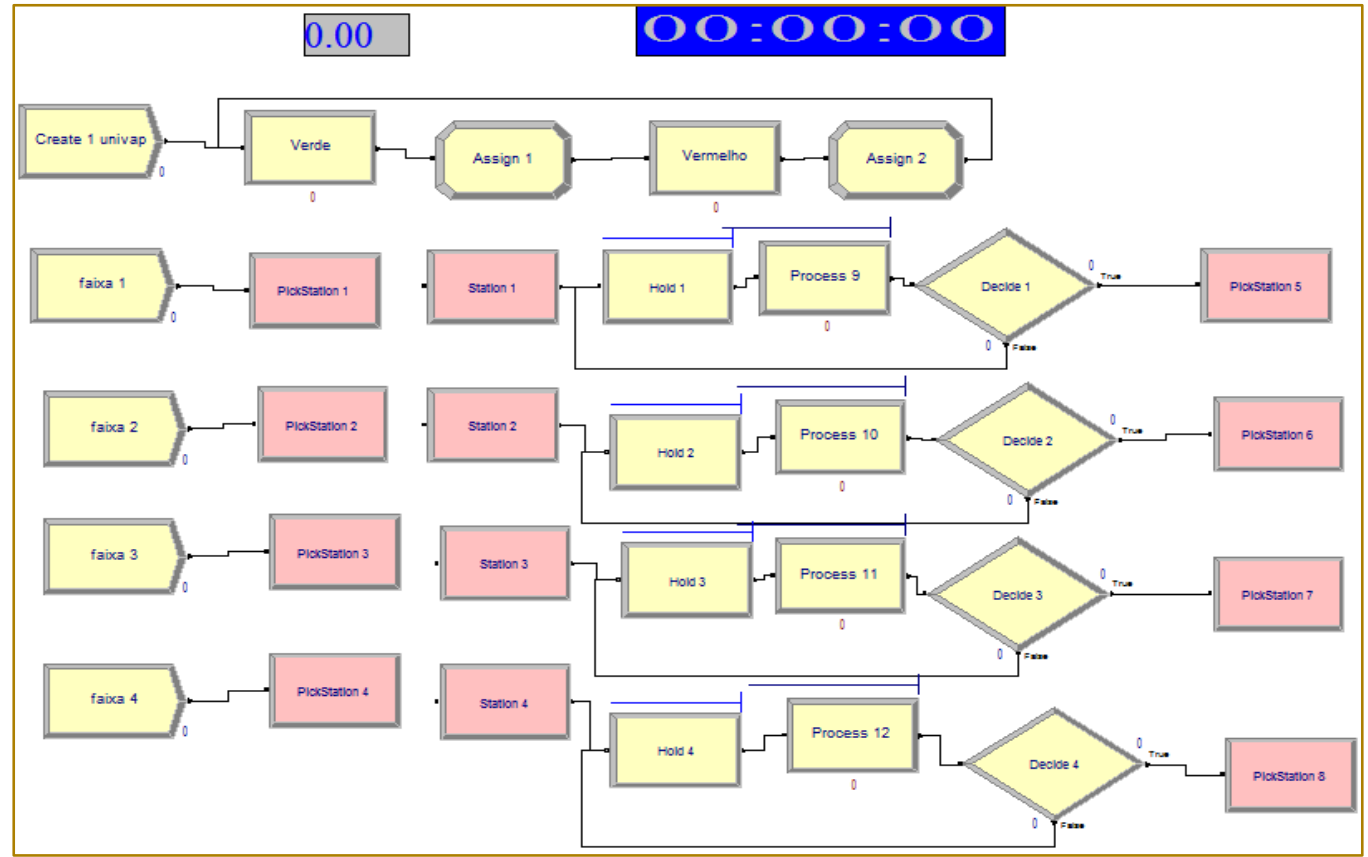

Fonte: Autores (2018)

Os elementos do modelo de simulação devem ser entendidos como se segue abaixo:

O módulo Create (sinal), Process representa a luz verde de tempo médio 70; 74; 74 e 76 segundos, respectivamente, e o vermelho mais o amarelo são 50; 48; 46 e 44 segundos) e Assign representa a condição da liberação no sinal, se for "zero" é verde ou se for "um" é vermelho.

Os módulos Create (faixa) são responsáveis pela entrada de veículos na via, seguindo uma distribuição Exponencial de média 5 segundos.

Os módulos Pickstation são utilizados para distribuição dos veículos nas faixas com os tempo de rotas de $32 ; 15 ; 21 ; 15$ segundos na hora pico e fora da hora pico são 30; 16; 21; 15 segundos.

Os módulos Station são responsáveis pela entrada de veículos nas faixas.
Os módulos Hold ficam responsáveis na liberação do veículo no semáforo, quando for zero é liberado para passagem.

Os módulos Process demonstram 0 congestionamento da via dado em 0,5 segundos.

Os módulos Decide representam a condição na continuidade na via, se for "zero" segue, caso seja "um" volte para a fila, nesta condição retorna para o Hold.

O mesmo modelo é usado nas quatro formas somente substituindo os dados, tanto para hora de pico quanto fora de pico. Os resultados obtidos foram baseados em inputs estabelecidos pelos autores em estudo de campo. Esses inputs fazem referência às distribuições estatísticas inseridas nos módulos do modelo Arena. Para verificar a viabilidade da faixa exclusiva foram comparados os seguintes indicadores (Quadro 1): 
Quadro 1 - Comparação dos Critérios

\begin{tabular}{|l|c|c|c|c|}
\hline \multicolumn{1}{|c|}{ Indicadores } & $\begin{array}{c}\text { Fora da hora de pico } \\
\text { Com faixa exclusiva }\end{array}$ & $\begin{array}{c}\text { Fora da hora de pico } \\
\text { Sem faixa Exclusiva }\end{array}$ & $\begin{array}{c}\text { Hora de pico } \\
\text { Com faixa exclusiva }\end{array}$ & $\begin{array}{c}\text { Hora de pico } \\
\text { Sem faixa Exclusiva }\end{array}$ \\
\hline Tempo de permanência na fila & 0,6414 & 0,6463 & 0,753 & 0,7564 \\
\hline Tempo total no sistema & 2,0532 & 2,0656 & 2,1877 & 2,1754 \\
\hline Work in process & 101 & 101 & 107 & 106 \\
\hline
\end{tabular}

Fonte: Autores (2018)

Os critérios em comparação são entendidos da seguinte forma:

- Tempo de permanência na fila: tempo médio que o veículo fica na fila (em minutos).

- Tempo total: tempo que ficou no sistema na entrada e na saída (em minutos).

- Work in process: quantidade de veículos no sistema.

Os dois critérios fora da hora de pico com e sem faixa exclusiva demonstram uma diferença mínima de 0,0049 minutos no tempo de permanência na fila. $O$ tempo total no sistema tem um aumento de 0,0124 minutos e o work in process são iguais. Com estes dados identifica-se que sem a faixa exclusiva há um aumento muito baixo em relação ao critério com a faixa exclusiva e há um pequeno aumento nas filas no critério sem a faixa exclusiva, porém ambos não apresentam diferença na quantidade de veículos no sistema.

Os critérios na hora pico, com e sem faixa exclusiva, possuem o tempo de permanência na fila de 0,0034 minutos para mais na opção sem a faixa exclusiva, já o tempo total no sistema possui uma diferença menor sem a faixa exclusiva de 0,0123 minutos e o work in process tem uma diminuição de 01 veículo no sistema. Nestes critérios, a formação de fila possui um aumento, porém não é perceptível devido o tempo de permanência no sistema ser menor e a quantidade de veículos diminuir.

\section{REFERÊNCIAS}

[1]. BAIMA, C. Mobilidade tem forte efeito na economia e na qualidade de vida, afirma especialista. O Globo. Brasil, set. 2013. Não paginado. Disponível em: < http://oglobo.globo.com/sociedade/ciencia/revista-

\section{CONSIDERAÇÕES FINAIS}

Com o crescimento rápido da população e consequentemente um aumento de veículos, necessita-se de ideias que contribuam para a redução do tempo de locomoção. Com este intuito o estudo foi realizado para provocar a discussão da real necessidade ou vantagem da faixa exclusiva de ônibus.

Após o desenvolvimento de um estudo de caso e análise de indicadores, percebe-se que, se comparados os cenários com faixa exclusiva para ônibus e sem a faixa exclusiva para ônibus, não necessariamente a solução de faixas exclusivas traz alterações reais para melhorar a locomoção de pessoas, principalmente àquelas que não estão utilizando o sistema de transporte coletivo.

No problema desenvolvido, o resultado obtido com a utilização da faixa exclusiva na hora de pico foi de 2,1877 minutos em média, já na análise sem a faixa exclusiva, também em hora de pico, o resultado foi de 2,1754 minutos em média. Com isto, não se pode afirmar que a faixa exclusiva necessariamente atrapalha o fluxo nas vias que se sobram para a locomoção da população.

No estudo apresentado, conclui-se que a faixa exclusiva não traz malefícios aos usuários da via. Sugere-se como trabalhos futuros que seja analisado o efeito da faixa para o usuário do transporte coletivo. Caso não haja vantagem para esse tipo de usuário, a faixa de ônibus se tornou um investimento sem resultados para a população.

amanha/mobilidade-tem-forte-efeito-naeconomiana-qualidade-de-vida-afirma-especialista9912420>. Acesso em: 5 mar. 2018. 
[2]. CINTRA, M. (2013). A crise do trânsito em São Paulo e seus custos. G Vexecutivo, 12(2), 5861.

[3]. FERRAZ, A.; TORRES, I., 2004, Transporte público urbano. (2 $2^{\mathrm{a}}$ ed.) (São Carlos: Rima).

[4]. INSTITUTO BRASILEIRO DE GEOGRAFIA E ESTATÍSTICA (IBGE). Pesquisa Industrial Mensal - Produção Física (PIM-PF). 2014. [2014a] Disponível em: <http://.sidra.ibge.gov.br>. Acesso em: 20 mar. 2018.

[5]. LEONARDI, A. Reduzir espaço para carros torna a cidade melhor, diz especialista inglês. G1. Brasil, set. 2015. Não paginado. Disponível em: <http://g1.globo.com/saopaulo/noticia/2015/09/red uzir-espaco-para-carros-torna-cidade-melhor-dizespecialistaingles.html>. Acesso em: 5 abr. 2018.

[6]. LANZONI, C.; SCARIOT, C. A.; SPINILLO, C. G. Sistema de informação de transporte público coletivo no Brasil: algumas considerações sobre demanda de informação dos usuários em pontos de parada de ônibus. Info design (SBDI. Online), v. 8, p. 54-63, 2011.

[7]. NASCIMENTO, M. V.; TOZI, L. A. . Análise de atributos determinantes na decisão do usuário do sistema coletivo de transporte público. In: XXIV ANPET - Congresso de Pesquisa e Ensino em Transportes, 2010, Salvador. Panorama Nacional da Pesquisa em Transportes, 2010.

[8]. NATO/CCMS. Bus Priority Systems. North Atlantic Treaty Organisation and the Committee on the Challenges of Modern society, CCMS Report No 45, London. U. K., 1976.

[9]. NELSON, J. D. e HILLS, P. J. Innovative bus control for congested urban corridors: the application os convoying systems. Traffic Engineering and Control, 1990.

[10]. PREVIDELLI, A. A solução para mobilidade urbana? Ônibus, diz Peñalosa. Revista EXAME. Brasil, set. 2013. Não paginado. Disponível em:<http://exame.abril.com.br/mundo/noticias/asolucao-para-mobilidade-urbana-onibusdizpenalosa>. Acesso em: 23 abr. 2018.

[11]. SILVA, D. Sistemas Inteligentes no transporte público por ônibus.143 f. Dissertação (Mestrado em Engenharia de Produção) Departamento de Engenharia de Produção, Universidade Federal do Rio Grande do Sul, Porto Alegre, 2000

[12]. RESENDE, P. T. V. D., \& SOUSA, P. R. D. Mobilidade urbana nas grandes cidades brasileiras: um estudo sobre os impactos do congestionamento. SIMPOI-SIMPÓSIO DE ADMINISTRAÇÃO DA PRODUÇÃO, LOGÍSTICA E OPERAÇÕES INTERNACIONAIS, FGV, 2009.

[13]. TCQSM - Transit Capacity and Quality of Service Manual. TCRP Web Document 6. TRB, National Research Council, Washington, D.C., 1999 http://www4.nas.edu/trb/crp.nsf/All+Projects/TCRP $+\mathrm{A}-15$

[14]. VAZ, J.C; Santoro, P. 2009. Cartilha Mobilidade urbana é desenvolvimento urbano! 2005.Disponível em: $<$ http://www.polis.org.br/publicacoes_interno.asp?c odigo $=194>$. Acesso em: 20 abr. 2018.

[15]. WHITE, P (1986). Public transport: is planning, management and operation. The Built Environment Series, 2nd edition, Londres, U. K., 1986. 


\section{Capítulo 19}

\section{CRM - FERRAMENTA DE GESTÃO: RELACIONAMENTO COM O CLIENTE NA EMPRESA FORNECEDORA DE GÁS GLP A GRANEL}

\section{Maristela de Freitas}

Rafael Rolando Mitteenn Muñoz

Thais Masague Mizani

Keli Cristiane Vido

Resumo: Este artigo objetivou analisar a relevância da utilização do CRM para a gestão e, portanto da qualidade do relacionamento com o cliente. Para tal, o estudo ancorou-se método qualitativo descritivo e ancorado em uma revisão bibliográfica e estudo de caso em uma empresa Distribuidora de Gás GLP, departamento de distribuição a granel que atua no atendimento a empresas e condomínios, delimitado a análise da gestão do relacionamento do cliente por meio do uso do CRM. Vale ressaltar que a empresa objeto de estudo é a primeira em fornecimento de gás do Brasil atuando desde 1937, e nos últimos anos o crescimento no consumo do produto a granel foi de $18,9 \%$ no território brasileiro, fatores que corroboram com a importância desse estudo. Ainda ressalta-se que a distribuidora possui estratégias avançadas de gestão, incluindo o CRM, contudo evidenciou-se por meio do estudo que a ferramenta é utilizada de forma parcial. Assim sendo, a investigação como contributo trouxe a análise dos alcances e limites da efetividade do uso do CRM no relacionamento com o cliente e possíveis impactos nos resultados desse cenário.

Palavras-chave: CRM. Atendimento. Distribuidora. 


\section{INTRODUÇÃO}

Neste estudo, adquiriu-se a percepção sobre os procedimentos adequados ao uso do CRM. Na Companhia Distribuidora de Gás Liquefeito de Petróleo - GLP, investigação viabilizou comprovar a efetividade da ferramenta no atendimento ao cliente, seus limites, abrangência e quais os impactos na cultura colaborativa da empresa.

Em 1997 a empresa implantou o sistema de abastecimento a granel para atender empresas de pequeno e médio porte $e$ condomínios, desde então foram necessárias restruturações internas para sua condução no mercado conforme as variações na economia, viabilizando ampliar seus investimentos.

Diante desta dinâmica econômica, com o crescimento do mercado imobiliário no país, estimulou a necessidade de aprimorar o uso da tecnologia no atendimento ao cliente. Esta pesquisa sugeriu a utilização de um software de CRM, porém é utilizada de forma parcial.

A temática abordada objetivou a aplicação de método qualitativo descritivo e observatório, através dos dados obtidos a pesquisa com base bibliográfica proporcionou compreender os possíveis impactos no relacionamento com o cliente.

\section{METODOLOGIA}

O presente artigo consistiu em um estudo qualitativo descritivo de uso bibliográfico, que trabalho buscou compreender através de estudo de caso dentro de empresa distribuidora de gás GLP a granel.

O desenvolvimento da pesquisa obteve o auxílio de artigos científicos publicados e pesquisa bibliográfica, que abordam a temática de implantação de software CRM. Este conforme Nogueira, Mazzon e Terra (2004, p.13) oportuniza "[...] uma boa administração de dados é essencial à prática do CRM" e, portanto a gestão do relacionamento do cliente de forma eficaz.
Assim sendo, o estudo investigou o processo de atendimento realizado na central de atendimento, através de dados obtidos em visitas supervisionadas, também pesquisas de satisfação do cliente da distribuidora de gás e quais os apontamentos que interferem diretamente no uso parcial do CRM e na gestão de relacionamento.

\section{SETOR DE GÁS}

Em 1954, o setor de gás no Brasil obteve crescimento através de subsídios aplicados pelo governo, impulsionando sua produção e aumentando da capacidade de distribuição logística em território nacional e em 2002 as empresas passam a operar com capital próprio. Segundo publicação do SINDIGAS (2015) no ano de 2014:

- as vendas do produto alcançaram a marca histórica de 7.421 milhões de toneladas no país;

- cerca de $100 \%$ dos municípios do Brasil são abastecidos com o gás GLP;

- cerca e 95\% da população brasileira é atendida, assim sendo aproximadamente 42,5 milhões de domicílios;

- $\quad$ contribui para a geração de 700 mil empregos diretos e indiretos.

O produto na matriz energética representa a $3,1 \%$ na economia do Brasil, dados SINDIGAS.(2016).

\subsection{NICHO DE ATUAÇÃO}

A distribuição do produto de gás a granel é direcionada a clientes com alta demanda de consumo, caracterizados como empresas de pequeno e médio porte e condomínios residenciais, que tem significativa importância na movimentação de capital. De acordo com o SEBRAE (2017) no Produto Interno Bruto PIB (2017):

Tabela 1 - Representação das empresas no PIB do Brasil

\begin{tabular}{|c|c|}
\hline Representação das empresas no PIB do Brasil em 2017 & $\%$ \\
\hline Empresas de Pequeno Porte & 24,5 \\
\hline Empresas de Médio Porte & 22,5 \\
\hline
\end{tabular}

Fonte: Adaptado SEBRAE (2017). 
Conforme a tabela 1, mesmo com as oscilações na economia do país, os dados apresentam que estes clientes têm demanda de abastecimento, gerando assim a necessidade de atendimento ao cliente com qualidade. A empresa distribuidora de gás GLP a granel atua há aproximadamente 20 anos neste mercado. É relevante assim salientar o relacionamento com o cliente utilizando através da ferramenta CRM envolvendo todos os setores da companhia.

\subsection{ATENDIMENTO AO CLIENTE}

Segundo Freemantle (1994, p. 13) "O atendimento ao cliente é o teste final, você pode fazer tudo em termos de produto, preço e marketing, mas, a não ser que você complete o processo com um atendimento ao cliente incrivelmente bom, corre o risco de perder negócios ou até mesmo sair do negócio". O suporte direto ao cliente, também conhecido como atendimento é considerado a principal fonte de comunicação entre a empresa e o consumidor, independente do tipo de solicitação que for desejada. Mas o que estabelece um padrão adequado de atendimento ao cliente em tempos de transformações culturais, novas tecnologias e informação em tempo real, o estudo assimilou a complexidade por intermédio de citações bibliográficas:

Segundo Dantas (2011), a visão clássica de atendimento consiste no fornecimento do produto, o comportamento amigável, sendo que os elementos relacionados ao produtos que determinam o valor de compra e o nível de satisfação dos clientes são sintetizados por meio de:
a) preço.
b) padrão de qualidade.
c) especificações em relação as exigências do comprador.

d) atividades pré e pós venda.

Dantas (2011) atribui em sua obra, que o modelo de atendimento anterior consiste no produto e o preço em si ser o principal foco de satisfação do consumidor. O fluxo das informações na era da globalização, e os novos meios de aquisição de serviços, transformaram a visão de atendimento ao público, sendo atribuídas novas definições em função das exigências atuais do cliente, sendo relacionados novos elementos que determinam o valor de compra ao serviço agregado. $\mathrm{O}$ autor cita:

Dantas (2011, p. 38) " o atendimento ao público é uma atividade complexa e que interagem vários elementos, para melhorá-lo é preciso que se tenha uma visão global e integrada de todos os aspectos considerados relevantes".

O resultado é a gestão de relacionamento com o cliente, em que o foco consiste nas ações da organização em detrimento da satisfação dos consumidores ao invés de focar em si próprias. A gestão de relacionamento com o cliente pode envolver diversas áreas da empresa, como marketing, vendas e serviços de atendimento, mas para que a gestão de relacionamento seja eficiente, se faz necessário que a empresa opte por investir em atendimento relacional, que consiste em trabalhar com a padronização dos procedimentos entre as áreas da empresa interligando a comunicação via sistema CRM.

Para que na outra ponta o colaborador que atua na linha de frente tenha suporte para oferecer atendimento satisfatório, baseandose em um alinhamento da empresa aos valores do cliente, o autor Pedron (2003) conclui que é preciso desenvolver a consciência dos colaboradores acerca de sua importância no papel que desenvolve na empresa e suas vantagens.

Investir em treinamentos somente na linha de frente do atendimento é importante, mas ainda não é modelo ideal de atendimento ao cliente, se faz necessário envolver todas as áreas neste processo da empresa e compreender que o cliente esta comprando valor subjetivo, não somente o serviço.

Segundo Massey, Montoya Weiss e Holcom (2001) Indiferente do tamanho ou setor de atuação, uma empresa, ao aprender mais sobre as necessidades e sobre o comportamento do seu cliente, acaba se tornando mais forte e lucrativa.

O setor comercial poderá assegurar uma vantagem competitiva em relação a concorrência, o maior objetivo é manter o consumidor satisfeito através da confiança e a credibilidade que trata da segurança transmitida através do atendimento, construindo assim relacionamentos mais duradouros que poderão contribuir no aumento do desempenho em resultados satisfatórios. O software adequado que 
auxiliará no atendimento ao cliente é o CRM, que organiza preferências, necessidades de consumos e expectativas dos consumidores.

\subsection{CRM - GESTÃO DE RELACIONAMENTO}

Customer Relationship Management (CRM) trata-se da gestão do relacionamento da empresa com seu cliente, visando fortalecer e/ou criar uma fidelidade, visa também em atender as necessidades dos clientes atuais e potenciais existentes. Assim, esta ferramenta captura e consolida os dados sobre os clientes, analisa as informações e dispõe de resultados que podem ser utilizados para a interação e negociação com o cliente.

De acordo com Peppers \& Rogers Group (2004) o CRM possui como principais funcionalidades descrita na tabela 2, a seguir:

Tabela 2 - Tipos de CRM

\begin{tabular}{|c|c|}
\hline a) Operacional & $\begin{array}{l}\text { atenção voltada a criação dos canais de relacionamento com cliente, como por } \\
\text { exemplo canais de venda. }\end{array}$ \\
\hline b) Analítico & $\begin{array}{l}\text { é a ação de analisar estes dados e gerar o conhecimento e tornar estes em } \\
\text { estratégias de negócios (CRM Estratégico) voltada a identificação das } \\
\text { necessidades dos clientes antecipadamente. }\end{array}$ \\
\hline c) Colabor & $\begin{array}{l}\text { esta é a fase no qual cria-se o valor ao cliente, baseado no conhecimento através } \\
\text { da integração dos setores para o contato com o cliente, seja via e- mail, telefone, } \\
\text { feedback e redes sociais (CRM Social), o foco ter valor com o contato com cliente. }\end{array}$ \\
\hline
\end{tabular}
Fonte: Peppers \& Rogers Group (2004)).

A distribuidora de gás atua com o CRM operacional com sua equipe de atendimento ao cliente que capta as informações ligadas aos seus clientes, comestas informações a empresa trabalha seu CRM analítico para criar estratégias de negócios.

Conforme as informações aludidas, pode-se compreender que o CRM contribui para a gestão do relacionamento com o cliente, desde que este seja utilizado da forma correta e em uma cultura colaborativa dos departamentos.

O CRM viabiliza estratégias que permite a todos os setores de uma empresa a obter visão única do cliente. Segundo Madruga (apud Sakamoto, 2000, p. 51)

"CRM é o conceito que prevê a integração de todas as áreas de uma empresa, principalmente vendas, call center, logística, marketing e internet, de modo a fidelizar a carteira existente e torna-la mais lucrativa. A ferramenta possibilita mais eficiência a gestão de relacionamento e eficácia na qualidade de atendimento."

\subsection{LIMITES DO CRM E SEU ALCANCE}

Para Barkley (2000) entende-se que o CRM se utilizado de forma adequada pode trazer beneficios para as empresas de diversos ramos e portes. Já a limitação do CRM pode variar a partir de duas vertentes, horizontal e vertical, sendo a horizontal composta pelas áreas internas da empresa, como exemplo: setores de autorização, manutenção, cálculo de valores e simulações de campanhas e a vertente vertical apresenta a limitação quando a ferramenta do CRM não atende a necessidade em companhias do ramo têxtil, alimentação entre outros.

\section{ESTUDO DE CASO E DADOS COLETADOS}

O estudo ancorou-se para sua consecução no estudo de caso da área de relacionamento com o cliente da Companhia Distribuidora de Gás GLP a Granel, respaldado por revisão qualitativa descritiva bibliográfica, a respeito do atendimento ao cliente, fluxo logístico de informações entre as áreas e a utilização do sistema CRM, em que o referencial teórico buscou identificar e apresentar os resultados obtidos.

A Distribuidora de gás GLP a granel, sendo pioneira neste mercado, atua aproximadamente há 20 anos no ramo químico, e desde 1997 implantou o sistema de abastecimento a granel para atender empresas de pequeno e médio porte e condomínios. Segundo dados oficiais publicados pela Agência Nacional do Petróleo

- ANP (2017), este gráfico apresenta o crescimento das empresas de gás GLP no país em 2016, dentre elas, a da Distribuidora de Gás GLP: 
Figura 1 - Gráfico de análise de mercado de 2016

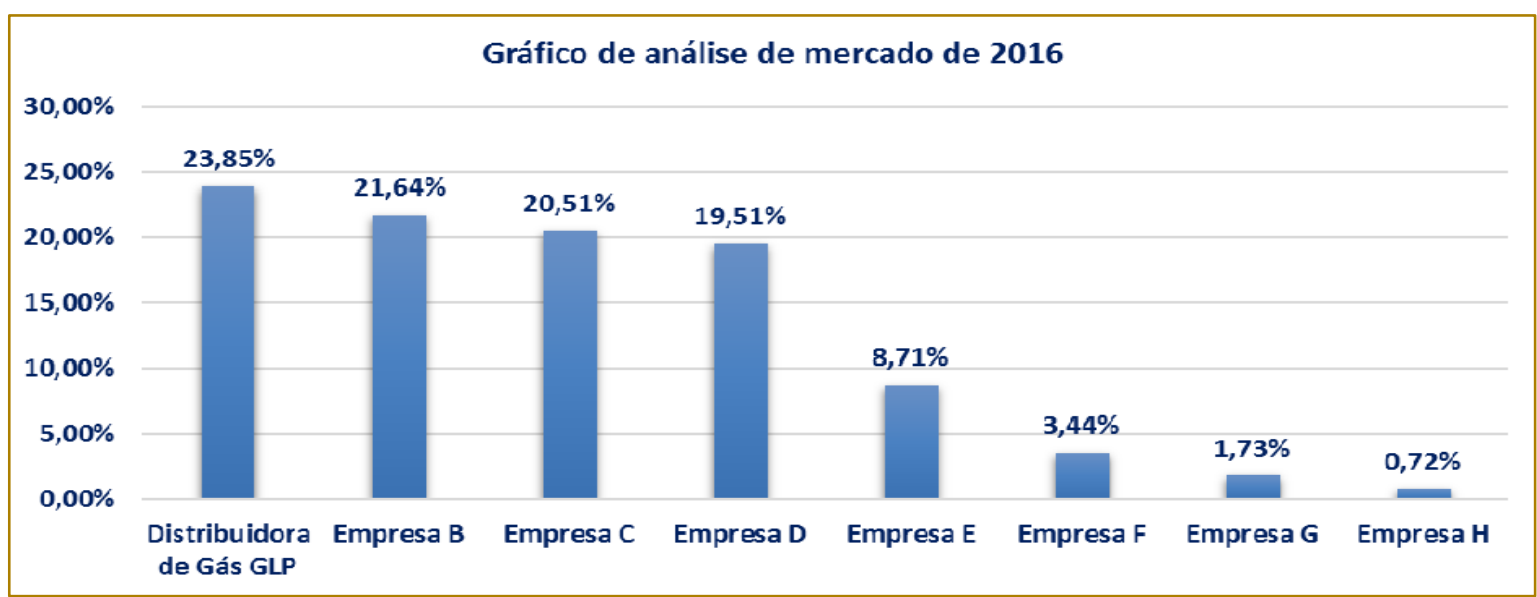

Fonte: Adaptado de Relatório - ANP Agência Nacional do Petróleo (2017)

Neste contexto, o gráfico representado pela figura 1 demonstra que a Distribuidora de gás GLP é a primeira e a maior empresa do ramo químico em relação à análise de mercado, dispondo de grande distribuição de gás por todo o Brasil.

Como objeto de estudo, no mês de outubro de 2017, a Distribuidora permitiu visitas supervisionadas na área de atendimento ao cliente, o qual foi possível identificar todo o procedimento para atender as demandas.

O processo de atendimento demonstrado através do Anexo $A$, apresenta como é realizado $O$ atendimento para todas as solicitações recepcionadas na central de atendimento. Quando o cliente realiza o contato com a central, é iniciado um protocolo de solicitação ou informação, o atendente identifica qual o processo necessário e segue com o prazo devido para a tratativa. Dependendo do prazo estimado e do retorno da área responsável, a data pode ser prorrogada, o que foi observado um índice de insatisfação do cliente por não ter sido atendido no prazo. Entretanto, no período necessário de análise, observaram-se dificuldades no retorno com o cliente no prazo estipulado e ausência de informações dos clientes na plataforma do CRM, que a empresa disponibiliza, sendo uma ferramenta que agiliza o processo de atendimento.

Ainda por meio dos dados do gráfico demonstrado na Figura 2 refere-se ao segundo semestre de 2017 em que foi possível identificar os motivos solicitação da rescisão macro de contrato, relacionados inclusive com o atendimento:

Figura 2 - Pedido de rescisão de contrato (Macro)

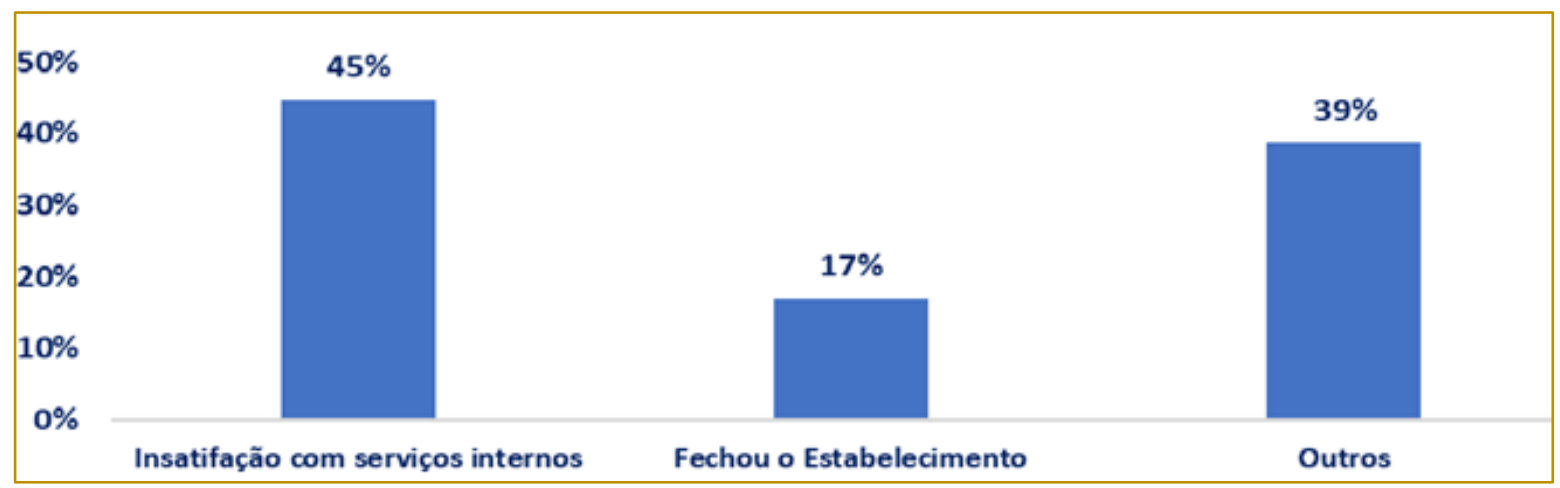

Fonte: Relatório Adaptado do Sistema de CRM (2018) 
O gráfico representado pela figura 3 também evidencia que através do relatório gerado no software de CRM da companhia, referente as solicitações de rescisão de contrato encontram-se os motivos pelo qual houve a abertura do pedido de rescisão do contrato para distribuidora de gás, o relatório apresentou que o maiores motivos de solicitação de rescisão do contrato se deve a insatisfação do cliente com os serviços internos da empresa, seguidos da solicitações devido ao fechamento dos estabelecimentos e motivos específicos dos clientes (outros). O gráfico da figura 3 representa a insatisfação dos clientes em relação aos serviços internos da empresa e seus relacionados.

Figura 3 - Insatisfação com serviços internos

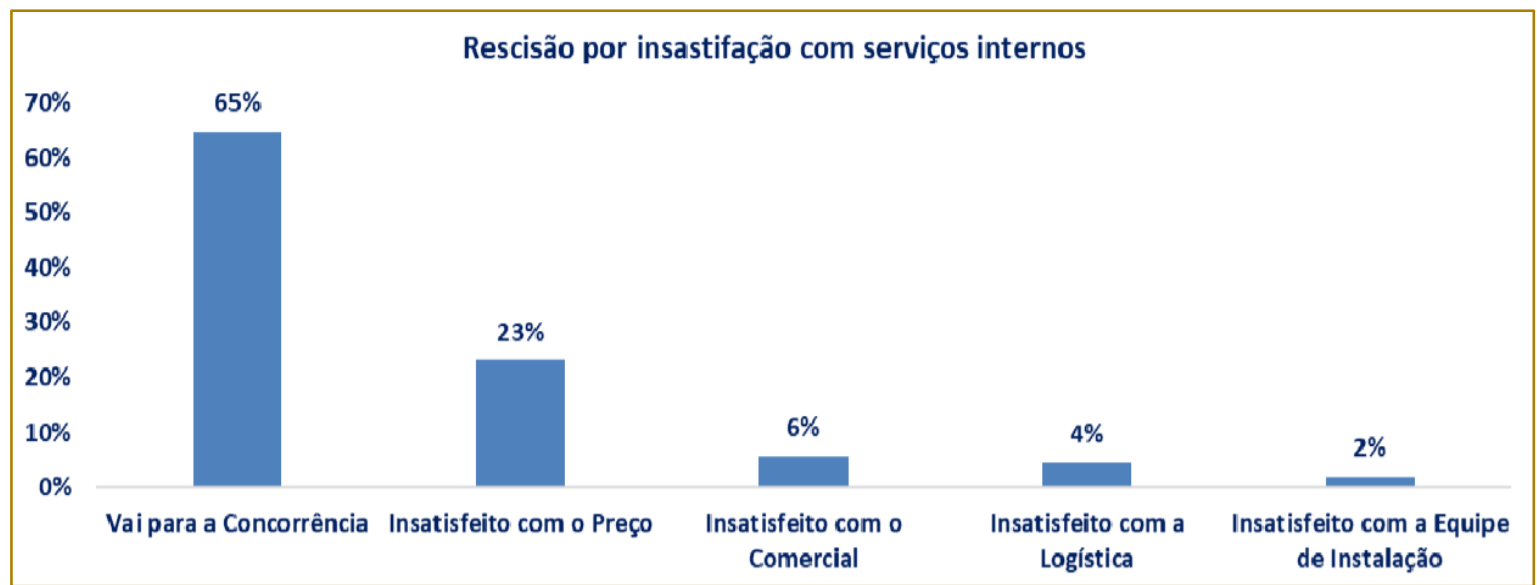

Fonte: Adaptado do sistema de CRM (2017)

Insatisfeito com o preço: O preço é um dos motivos pelo qual o cliente procura outras companhias que prestam o mesmo serviço.

- Insatisfeito com o comercial: O departamento comercial é o uma das áreas que presta o atendimento ao cliente, se esta área não auxilia os clientes, eles podem desistir do contrato com a companhia.

- Insatisfeito com a logística: A área de logística esta relacionada com o eficácia das entregas, os atrasos nas entregas acarreta negativamente a visão do cliente com 0 atendimento.

- Insatisfeito com a equipe de instalação: A equipe de instalação é um dos contatos direto da empresa com o cliente, se o atendimento que a equipe presta não for de agrado do cliente, isso irá gerar uma visão negativa da empresa para o cliente, sendo passível de solicitação de rescisão de contrato.

- Vai para a concorrência: É uma junção de dois ou mais motivos de insatisfação do cliente com os serviços internos da empresa.
Assim sendo, o relatório de rescisão de contratos apresentou que a maior porcentagem das solicitações são com os motivos que envolvem $\mathrm{O}$ atendimento do cliente, o que reforça que os clientes estão dispostos a pagar mais para outras companhias se o atendimento ao cliente for melhor, segundo DANTAS (2011) os fatores de um bom atendimento está relacionado a cortesia, a simpatia, a educação do atendente e sua proatividade, e em relação ao comercial sempre cumprir com suas promessas e ofertas que foram informadas ao cliente.

O setor comercial poderá assegurar uma vantagem competitiva em relação a concorrência, o maior objetivo é manter o consumidor satisfeito através da confiança e a credibilidade que trata da segurança transmitida através do atendimento, construindo assim relacionamentos mais duradouros que poderão contribuir no aumento do desempenho em resultados satisfatórios.

Neste aspecto Carvalho (2014) discorre que o CRM é uma cultura, pois ter apenas um sistema ERP de CRM não é o suficiente se não houver uma cultura na organização com o 
foco em atender seus clientes, e obter informações de valor. Portanto quando há a intenção de praticar o CRM de forma estratégica, a empresa cria um contato maior com seus clientes, conhece os seus hábitos, cria eventos, promoções e campanhas direcionadas, torna o atendimento mais personalizado e consegue a fidelização.

Uma das funções do CRM, na distribuidora de gás é entender os motivos pelo qual acontecem as solicitações de rescisão dos contratos, através de softwares apropriados e uma cultura com o foco no atendimento ao cliente é possível coletar as informações referente aos processos de rescisão resultando a criação de estratégias de negócios eficazes junto ao CRM.

Em comparação com os dados apresentados da Figura 4, foi possível identificar motivos semelhantes com as reclamações inscritas no site Reclame Aqui, no segundo semestre de 2017, com maior impacto em relação aos serviços internos da empresa, como apresenta:

Figura 4 - Reclamações registradas no segundo semestre de 2017

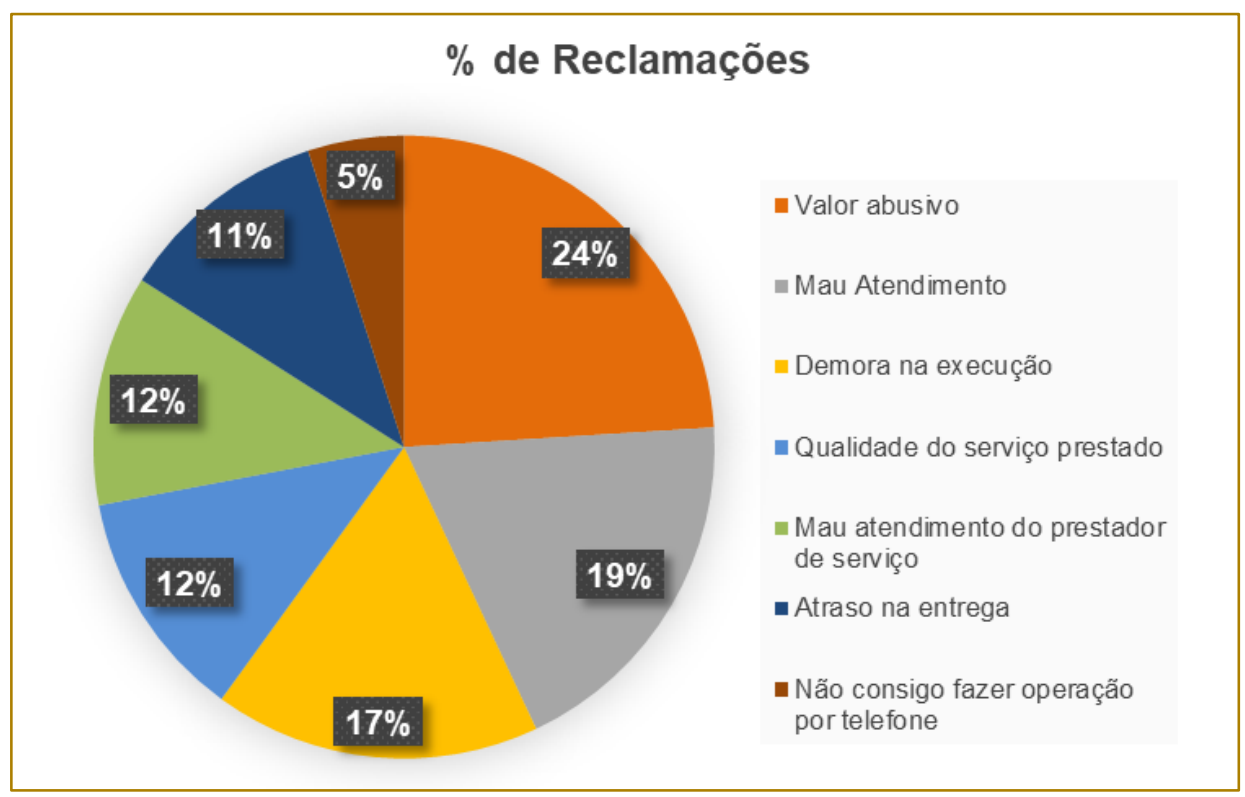

Fonte: Adaptado Reclame Aqui (2018)

Com as vertentes apresentadas, foi possível identificar insatisfações com serviços internos da Distribuidora, o que corresponde ao total de $76 \%$ em relação ao atendimento e apenas $24 \%$ em relação ao valor do produto.

No que se refere ao planejamento da empresa sendo bem estratégico e desenvolvido pode assegurar também uma gestão estratégica, controlada, ordenada e bem direcionada em todos os setores e o CRM, sendo uma ferramenta imprescindível, se utilizada de forma integral oferece grandes vantagens competitivas.

Na Distribuidora, evidenciou-se que o CRM é utilizado de forma parcial pelos colaboradores, assim o estudo apresenta insatisfações dos serviços internos, e a ferramenta oferece informações e prevê comportamento dos clientes, o que torna o processo de atendimento eficiente, por envolver agilidade de processos, no retorno de solicitações dentre outras vantagens que facilitam as atividades realizadas no cotidiano. Conforme Bretzke (2000, p. 28):

\section{A estratégia de CRM dispõe da tecnologia que permite enriquecer o relacionamento com os clientes, coletar informações sobre qualquer contato que ocorra por qualquer meio, on-line e em tempo real, da mesma forma que os dados de vendas e financeiros, e realizar as análises dos clientes de forma mais flexível.}

No contexto aludido por meio da análise dos dados pode-se evidenciar que...., entre diversas funções do CRM, o uso da ferramenta proporciona antecipadamente informações sobre o cliente, o que enriquece o relacionamento da empresa e organização, - que torna o CRM uma estratégia de negócios. 


\section{CONSIDERAÇÕES FINAIS}

Com base no estudo observatório qualitativo, a coleta de dados e a pesquisa bibliográfica, os resultados obtidos no atual contexto que a empresa distribuidora de gás GLP a granel, apontam que o software CRM é utilizado de maneira parcial pelos demais setores, que armazenam informações em outros sistemas que são parcialmente integrados ao CRM, resultando na limitação de informações para a central de atendimento, que é o principal canal de relacionamento com o cliente da empresa, gerando as demandas, estendendo os prazos para a tratativa das solicitações, acionando as áreas específicas conforme a demanda, levando novo contato a central e ocasionando a insatisfação do cliente.

O cenário apresentado determinou os rumos desta pesquisa a uma sugestão de melhoria continua. O autor Inglis (2002) define três tipos de ferramentas estratégicas para aperfeiçoar o nível de atendimento ao cliente:

- Segmentação de mercado ao qual permite conhecer as afinidades entre os grupos de clientes.

\section{REFERÊNCIAS}

[1]. ABREU, C.B. Serviços pós-venda: a dimensão esquecida do marketing. Revista de Administração de Empresas, v.36, n.3, ppp 24 - 31, 1996.

[2]. Administradores.com. Disponível em <http://www.administradores.com.br> Acesso em 07 de Abr. 2018.

[3]. BALLOU, R.H. Gerenciamento da cadeia de suprimentos/logística empresarial. 5 Ed. Porto Alegre: Bookman, 2006.

[4]. BOSE, Ranjit. Customer relationship management: key components for IT success. Industrial Management \& Data Systems. MC BUP Ltd, 102/2, p.89-97, 2002. Disponível em:< https://www.emeraldinsight.com/doi/abs/10.1108/0 2635570210419 63> . Acesso em 19 abr. 2018.

[5]. BRAMBILLA, Régis. Indicadores Tecnológicos e organizacionais do Customer Relationship Management (CRM): relação entre firma desenvolvedora, firma usuária e preceitos teóricos. Perspect. ciênc. inf. [online]. 2008, vol.13, n.2, pp.107-129.

[6]. ISSN 1981-5344, Anais Faculdade Integrada do Ceará -FIC. Disponível em <http://d x.doi.org/10.1590/S1413-9936200800020009>.

Acesso em 09 de Abr. 2018
- A comparação de oferta em relação aos seus concorrentes analisando cada proposta e suas vantagens e desvantagens.

- Identificação de canais disponíveis para o marketing englobando a evolução da empresa com canais de comunicação para com o cliente, organizando o estabelecimento para o produto.

Este estudo contribui para uma análise da utilização do software CRM, que viabilizou informações para a gestão de relacionamento com o cliente e qualidade de atendimento efetiva, sendo imprescindível o uso da ferramenta em sua totalidade, para atingir um grau adequado a satisfação do cliente, é importante aperfeiçoar uma cultura colaborativa na empresa.

A efetividade do CRM, irá depender do compromisso da empresa com esta ferramenta, pois apenas coletar as informações sobre o cliente que é tratado, não é o bastante, é importante também aprender a conduzir/tratar estas informações para que ocorra o conhecimento prévio de seus clientes afim de criar valor e estratégias de negócio.

[7]. CLRB - Conselho de Logística Reversa No Brasil. Logística Reversa. Disponível em: < http://www.clrb.com.br/site/clrb.asp>. Acesso em 09 de Abr. 2018.

[8]. COBRA, Marcos. Estratégias de marketing de serviços. 2. Ed. São Paulo: Cobra, 2001.

[9]. DANTAS, Edmundo Brandão; Atendimento ao público nas organizações. 5 Ed. Distrito Federal: Senac, 2011.

[10]. NOGUEIRA, R.; MAZZON, J. A.; TERRA, A. M. A gestão de CRM nas seguradoras. em: Encontro da Associação Nacional de Pós Graduação e Pesquisa em Administração Enanpad, 28., 2004, Curitiba. Anais....Curitiba: ANPAD,2004. Disponível em <http://www.scielo.br/scielo.php?script=sci_nlinks\& ref $=\quad$ 000194\&pid $=\quad$ S1413$9936200800020000900035 \& \mathrm{lng}=\mathrm{pt}>$. Acesso em 09 de Abr. 2018

[11]. MADRUGA, Roberto Pessoa S.; Implementação de crm para viabilização de marketing de relacionamento: um estudo de caso dissertação de mestrado; FUNDAÇÃO GETULIO VARGAS -RJ; 2002. Disponível em: $<$ http://bibliotecagigital.f gv.br/dspace/bitstream/handle/10438/8645/000320 652. pdf?sequence=1>. Acesso em 09 de Abr. 2018. 
[12]. MASSEY, Anne P.; MONTOYA-WEISS, Mitzi M.; HOLCOM, Kent. Re-engineering the customer relationship: leveraging knowledge assets at IBM. Decision Support Systems. v.32. p. 155-170, 2001. Disponível em: < https://asu.pure.elsevier.com/en/publications/reengineering-the-customer-relationship-leveragingknowledge-ass>. Acesso em 09 de Abr. 2018.

[13]. OLIVEIRA, W.J. CRM \& E-business, Florianópolis, Visual books, 2000, 154p.

[14]. PEDRON, C. D. Estratégia de CRM: Em direção a identificação de indicadores de desempenho. Perspectivas em ciências da informação. v.13, n.2, p.107-129, maio e ago. 2008.
Anais Unisinos, 2003. Disponível em:< http://www.sielo.br/scielo.php?scri pt=sci_nlinks\&ref $=000204 \&$ pid $=$ S1413$9936200800020000900040 \& \mathrm{lng}=p t>$. Acesso em 09 de Abr. 2018.

[15]. SITE OFICIAL. SINDIGÁS. Disponível em $<$ http://www.sindigas.com.br> Acesso em 09 Abr. 2018.

[16]. SITE OFICIAL. ANP- Agência Nacional do Petróleo. Disponível em: <http://www.anp. gov.br > Acesso em 09 de Abr. 2018

[17]. ZENONE, Luis Claudio. Customer relationship management (CRM) conceitos e estratégias. São Paulo: Atlas, 2001.

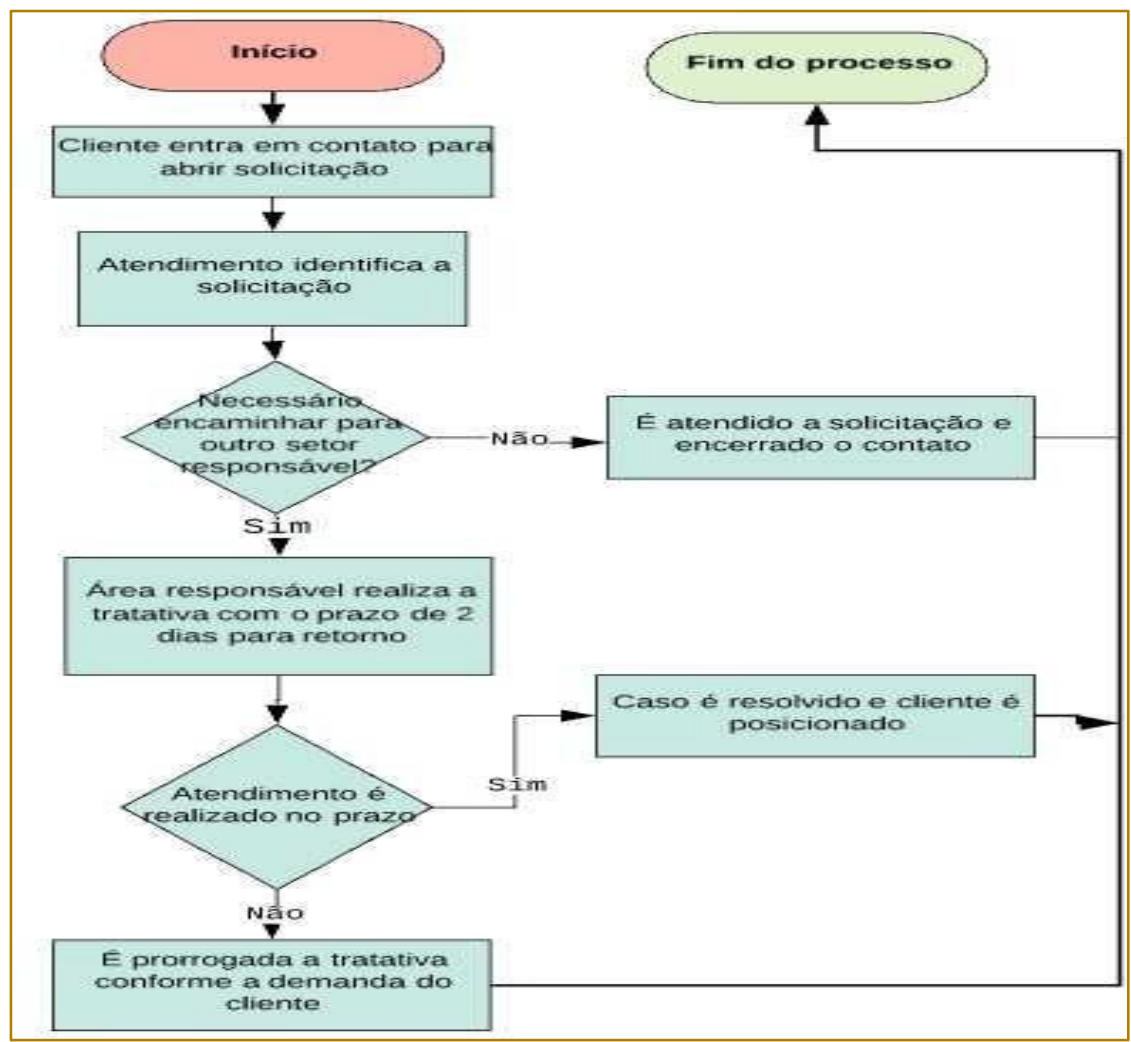




\section{Gapítulo 20}

\section{GESTÃO ESTRATÉGICA NA FORMAÇÃO DO PREÇO DE SERVICO: UM ESTUDO DOS MÉTODOS UTILIZADOS}

\section{Mariana Martins de Mesquita}

Vanusa Marisa Carvalho Magalhães Rocha

Jamile Brandão Silva

Lucineide Bispo dos Reis Luz

Armindo Aparecido Evangelista

Resumo: O foco do estudo está na análise da formação do preço de venda de serviço pelos métodos existentes, delimitado ao serviço de decoração infantil. 0 estudo desse tema foi escolhido por conta da alta dificuldade dos empresários da área de decoração infantil na formação do preço de venda, e também para avaliar e analisar a aplicabilidade dos demais métodos na formação do preço desse serviço. Assim considerando, esse trabalho tem como premissa responder a seguinte pergunta- problema: Qual é o melhor método de formação do preço de venda aplicada nos serviços de decoração infantil? O objetivo geral do estudo é avaliar a aplicabilidade do melhor método da formação do preço de serviço. O trabalho será desenvolvido através de pesquisa descritiva com abordagem analítica nas características e fatores, e estudo de caso no que diz respeito à formação de preço dos serviços de decoração infantil. Referente aos resultados, os piores métodos a serem praticados pela empresa são a formação de preço baseada em gastos mais margem de lucro e o custeio por absorção, pois apresentam prejuízo. Os melhores métodos são a formação de preço baseada em custos e o método RKW, que apresentam os maiores preços de venda. Conclui-se que, a empresa precisa reduzir os custos para continuar prestando o serviço na região, ou ter no mínimo quatro decorações por mês para ter um lucro de $R \$ 280,00$. Outra opção é expandir o atendimento para outras regiões, podendo aplicar valores maiores de acordo com a necessidade do cliente.

Palavras-chave: Precificação. Decoração infantil. Custos. 


\section{INTRODUÇÃO}

Acompanhar as alterações econômicas não é uma tarefa fácil para o empresário, e na maioria das vezes afeta o negócio de maneira catastrófica. Formar uma boa estratégia nas organizações influencia na formação do preço de venda, a qual se concretiza com a imposição do mercado, da concorrência, do governo e também do consumidor. Lembrando que a situação do mercado atual se adapta sempre por conta da alta competição que o serviço de decoração infantil enfrenta, e por conta das constantes mudanças que acontecem no setor.

A colocação da empresa no mercado visa sempre realizar sua missão, e ter sua continuidade, mas estes fatores dependem de seus resultados econômicos, que, consequentemente depende de uma boa relação entre preço e gastos que forem necessários para a realização e prestação do serviço.

O serviço de decoração infantil passa por todas as situações citadas, principalmente para realizar o desejo do consumidor, e para que o preço seja coerente e atraente é preciso uma gestão responsável na sua formação.

Este mercado tem atraído empresários que buscam um modelo de negócio prático, e de baixo custo e que apresenta rentabilidade. Entretanto, no decorrer do estudo usando como metodologia pesquisa bibliográfica acompanhada de um estudo de caso em uma empresa de decoração infantil, será evidenciado como o empresário faz uso da aplicação de formação do preço de venda, avaliando as diversas possibilidades da formação de preço de venda existentes na teoria.

O foco do estudo está na análise da formação do preço de venda de serviço pelos métodos existentes, delimitado ao serviço de decoração infantil. o objetivo geral do estudo é avaliar a aplicabilidade do melhor método da formação do preço de serviço.

Assim considerando, esse trabalho tem como premissa responder a seguinte perguntaproblema: Qual é o melhor método de formação do preço de venda aplicada nos serviços de decoração infantil?

Conhecer profundamente os métodos existentes para a formação do preço de venda poderá auxiliar os profissionais da área de decoração infantil na formação do preço, que atenda todas as suas necessidades e de seus consumidores, para então melhorar o desenvolvimento desse serviço.

O estudo desse tema foi escolhido por conta da alta dificuldade dos empresários da área de decoração infantil na formação do preço de venda, e também para avaliar e analisar a aplicabilidade dos demais métodos na formação do preço desse serviço.

O objetivo geral do estudo é avaliar a aplicabilidade do melhor método da formação do preço de serviço.Os objetivos específicos desse trabalho de curso são: Aplicar as metodologias de formação de preço de serviços de decoração infantil;Analisar as vantagens de cada método; Analisar as desvantagens de cada método; Auxiliar a tomada de decisão da melhor forma de formação de preço de venda.

Na teoria existem vários métodos de formação de preço, que serão analisados e aplicados de acordo com os dados obtidos da empresa, fazendo com que os sócios observem o que eles praticam de várias formas, e vejam quantos métodos são possíveis para analisar e decidir qual caminho seguir dentro da empresa de decoração infantil.

\section{REFERENCIAL TEÓRICO}

\subsection{INFORMAÇÕES IMPORTANTES}

Conhecer profundamente os métodos existentes para a formação do preço de venda poderá auxiliar os profissionais da área de decoração infantil na formação do preço, que atenda todas as suas necessidades e de seus consumidores, para então melhorar o desenvolvimento desse serviço.

\subsection{FATORES QUE INFLUENCIAM A PRECIFICAÇÃO}

Todo produto, mercadoria ou serviço precisa de um preço de venda. No entanto determinar o valor para tal, em um mercado onde ocorrem mudanças frequentes, se torna uma tarefa cada vez mais difícil. De acordo com Megliorini (2007, p.175)

Embora o gestor possa calcular os custos de um produto com o máximo rigor, utilizando diferentes métodos de custeio (por absorção, variável, $A B C$ etc.), no momento de definir o preço ele depara com um problema operacional altamente complexo. Além de proporcionar um retorno adequado ao 
investimento realizado, o preço está sujeito a aspectos que fogem ao controle da empresa, como as regulamentações governamentais, o avanço tecnológico, a obsolescência, a mudança do gosto do consumidor, os preços da concorrência, entre outros

Assim, decidir o preço de um produto envolve muito mais do que simplesmente efetuar cálculos. E segundo Perez, Oliveira e Costa (2010, p.274) "Vários fatores influenciam a formação de preço de um produto ou serviço, e o grau de influência de cada fator oscila ao longo do tempo como"

Embora existam inúmeros fatores, a concorrência é um fator que influencia diretamente na decisão dos gestores no momento da formação do preço, fazendo com que a sua dificuldade aumente.

\subsection{OUTRAS \\ INFLUÊNCIAS \\ PRECIFICAÇÃO}

NA

Outro conceito econômico que influencia a formação dos preços é o grau de elasticidade demanda/preço.

O grau de elasticidade é uma medida de sensibilidade da quantidade demandada em relação aos preços. Assim, a procura pode ser elástica quando as quantidades procuradas são relativamente sensíveis a alterações de preço.

A Lei da Oferta também influencia a precificação. Segundo Rossetti (1997:420)

A Lei da Oferta traduz-se no conceito de que a oferta de certo produto é determinada pelas várias quantidades que os produtores estão dispostos e aptos a oferecer no mercado, em função de vários níveis possíveis de preços, em dado período de tempo.

A curva da oferta é uma curva ascendente em relação ao preço. Quanto maior o preço, maior a oferta. Considerando que a Lei da Oferta e a Lei da Procura trabalham com forças opostas, a tendência é que estas forças estabeleçam um equilíbrio que satisfaça produtores e consumidores.

\subsection{ESTRUTURAS DE MERCADO QUE INFLUENCIAM A PRECIFICAÇÃO}

A teoria econômica estuda amplamente o processo de formação de preço. Além dos aspectos citados anteriormente, existem outros fatores que também o afetam o preço, como a estrutura de mercado. O mercado perfeitamente competitivo tem muitos compradores e vendedores e um produto homogêneo. Nesse mercado as empresas não podem cobrar um preço mais alto do que o preço de mercado, pois provavelmente ninguém compraria seus produtos, e também não vendem a um preço mais baixo, pois podem vender tudo o que produzem a preço de mercado.

No extremo oposto está o monopólio, em que as barreiras de entrada são tão altas que há apenas uma empresa no mercado, com produto, portanto, único. As empresas monopolistas determinam os preços. Alguns monopólios são decorrentes de barreiras legais. Outros são decorrentes de proteção de patentes, de conhecimento especializado ou de equipamento de produção de custo excepcionalmente alto.

A concorrência monopolista tem características do monopólio e da concorrência perfeita, mas é mais parecida com a situação competitiva. Basicamente, existem muitos compradores e vendedores, mas os produtos são diferenciados em alguns pontos.

\subsection{PROBLEMAS GERAIS NA FORMAÇÃO DE PREÇO}

Muitos empreendedores ainda atribuem o preço com base em seu custo, e os problemas surgem por conta da dificuldade de estabelecer quais são esses custos, pois ele pode ter valores diferentes dependendo do método de custeio utilizado.

Segundo Megliorini (2007, p.176) "Quaisquer que sejam os conceitos de mensuração utilizados para a apuração do custo, o paradigma aceitável é de que o preço representa uma equação".

$$
P=C+L
$$

Onde:

$$
P=\text { preço } C=\text { custo } L=\text { lucro }
$$

Outro problema é que vários empreendedores não conseguem usar esse padrão de formação de preço, pois esse método é possível em casos de monopólio. No padrão atual é o mercado que cita os preços, e isso faz com que o consumidor tenha mais força para influenciá-lo. E cabe então as empresas verificarem se é viável ofertar o serviço pelo preço que o mercado determina. 
Os métodos de formação de preço existentes na teoria são custeamento por ciclo de vida do produto, custo-meta, formação de preço baseada em custos, formação de preço baseada em gastos mais margem de lucro, abordagem RKW, custeio por absorção, custeio variável, margem de contribuição, markup e preço e venda orientativo.

Para melhor compreensão, os métodos serão aprofundados no capitulo 4 desse trabalho e terão aplicabilidade no mesmo, de acordo com os dados obtidos da empresa em estudo.

\subsection{APRESENTAÇÃO DA EMPRESA E DESCRIÇÃO DA SUA OPERAÇÃO PROCESSUAL DA FORMAÇÃO DE PREÇO}

A empresa Still Festas servirá de base para análise das informações obtidas ao decorrer do trabalho. Ela nasceu em agosto de 2000, uma empresa familiar que passou rapidamente de complemento de renda a fonte de renda principal de seus sócios proprietários (Sr. Pedro e Sra . Vanusa), que atuam diretamente na administração e execução dos serviços prestados.

Atualmente a empresa tem sede no mesmo local de residência dos sócios proprietários, sendo localizada na Rua Maniçoba no 211, Jd. Umarizal, Cep 05756- 420 São Paulo -SP. O capital inicial da empresa foi de $\mathrm{R} \$ 15.000,00$ (quinze mil reais) e o investimento foi crescendo de acordo com a demanda de serviços e consequentemente aumentando a lucratividade e rentabilidade.

Pensando que, este serviço é prestado por diversas empresas, os sócios proprietários observam que os clientes têm referência dos valores desses serviços, e consequentemente isso faz com que queiram cada vez mais preços baixos e descontos, leiloando preços e também julgando as empresas em função da política de preços adequada.

Por esse motivo os sócios proprietários decidem fazer pesquisa de quem são seus concorrentes diretos, ou seja, as empresas que atuam no mesmo segmento e oferecem os serviços nas mesmas condições e para o mesmo perfil de clientes (hábitos de compra, classe econômica e social, entre outras).

Ao analisar todos estes aspectos, a empresa conclui que é preciso praticar preços equivalentes ao mercado e ainda estabelecer outros diferenciais em relação à concorrência, que permite à empresa alta competitividade e interesse de escolha por parte dos clientes.

$\mathrm{Na}$ formação de preços são elaborados orçamentos diferenciados de acordo com o perfil de cada cliente, o que pode contribuir para se ter estratégias diferentes na hora de definir o preço final dos serviços.

Alguns dos motivos dessa diferença na formação de preço são:

- Graus de riscos;

- Garantias específicas;

- Interesse dos clientes em determinados serviços;

- $\quad$ Padrões de qualidade exigidos;

- Dificuldades envolvidas na execução, exclusividade da empresa;

- Grau de utilidade;

- $\quad$ Demanda de serviço;

- Parcerias com fornecedores de materiais utilizados (sazonalidades);

Ao analisar todos esses aspectos, observa-se que $\mathrm{o}$ método utilizado pelos sócios proprietários para a formação de preço é feito com base em pesquisa sócio econômica, variando de acordo com o perfil do cliente, região onde mora (quão dispendioso será o deslocamento até o local da prestação de serviço, levando em consideração custo financeiro e tempo decorrido), gastos com a compra do material e também com a mão de obra.

Agora serão apresentados os custos totais detalhados da empresa em estudo, tendo como base uma única decoração infantil realizada em uma região na zona sul de São Paulo. Deve ser observar que a empresa não tem despesas fixas ou variáveis. 


\begin{tabular}{|c|c|}
\hline Custos fixos & $\mathrm{R} \$ 1.262,96$ \\
\hline Aluguel & $\mathrm{R} \$ 560,00$ \\
\hline Energia elétrica & $\mathrm{R} \$ 64,00$ \\
\hline Água & $\mathrm{R} \$ 20,00$ \\
\hline Telefone / internet & $\mathrm{R} \$ 40,00$ \\
\hline DARF / MEI & $\mathrm{R} \$ 52,70$ \\
\hline Depreciação & $\mathrm{R} \$ 526,26$ \\
\hline
\end{tabular}

Base de Cálculo para depreciação de todos os itens utilizados em uma decoração infantil com vida útil estimada em 5 anos:

- Jogo de móvel utilizado com 4 mesas preço de mercado $R \$ 180,00$. Base de cálculo: 5 anos $X 12$ meses $=60$ meses $R \$ 180,00 / 60=R \$ 3,00$

- $\quad$ Escada preço de mercado $\mathrm{R} \$ 45,00$ Base de cálculo: 5 anos $\times 12$ meses $=60 \mathrm{~m}=$ $\mathrm{R} \$ 0,75$

- $\quad$ Armário preço de mercado $\mathrm{R} \$ 60,00$ Base de cálculo: $R \$ 60,00 / 60=R \$ 1,00$

- Banquinho preço de mercado $R \$ 40,00$ Base de cálculo: $R \$ 40,00 / 60=$ $\mathrm{R} \$ 0,67$
- Painel de lona preço de mercado $R \$ 250,00$ Base de cálculo: $R \$ 250,00 / 60=$ $\mathrm{R} \$ 4,17$

- $\quad$ Suporte preço de mercado $R \$ 150,00$ Base de cálculo: $R \$ 150,00 / 60=R \$ 2,50$

- Personagens valor de mercado $R \$ 300,00$ Base de cálculo: $R \$ 300,00$ / $60=$ $\mathrm{R} \$ 5,00$

- Inflador de balões preço de mercado $R \$ 550,00$ Base de cálculo: $R \$ 550,00$ / $60=$ $\mathrm{R} \$ 9,17$

- Veículo preço de compra $\mathrm{R} \$ 30.000,00$ Base de cálculo: $\mathrm{R} \$ 30.000,00$ / $60=R \$ 500,00$

\begin{tabular}{|c|c|}
\hline Custos Variáveis & $\mathrm{R} \$ 172,00$ \\
\hline Gasto com combustível & $\mathrm{R} \$ 50,00$ \\
\hline Gasto com balões & $\mathrm{R} \$ 50,00$ \\
\hline Gasto com barbante & $\mathrm{R} \$ 1,00$ \\
\hline Gasto com fita crepe & $\mathrm{R} \$ 1,00$ \\
\hline Tinta para manutenção & $\mathrm{R} \$ 20,00$ \\
\hline Gasto com mão de obra & $\mathrm{R} \$ 50,00$ \\
\hline Custos fixos totais & $\mathrm{R} \$ 1.262,96$ \\
\hline Custos variáveis totais & $\mathrm{R} \$ 172,00$ \\
\hline Custos totais apurados & $\mathrm{R} \$ 1.434,96$ \\
\hline
\end{tabular}

\section{METODOLOGIA}

Segundo Marconi e Lakatos (2008, p.223) "A especificação da metodologia da pesquisa é a que abrange maior número de itens, pois responde, a um só tempo, às questões como? com quê? onde? e quanto?".
O trabalho será desenvolvido através de pesquisa descritiva com abordagem analítica nas características e fatores, e estudo de caso no que diz respeito à formação de preço dos serviços de decoração infantil. As informações serão extraídas da empresa STILL FESTAS, que é atuante no mercado de decoração, para confrontar os métodos 
existentes de formação de preço com o qual a mesma utiliza atualmente, e por fim auxiliar na tomada de decisão do melhor método de formação de preço de venda.

\section{RESULTADOS E DISCUSSÃO}

Feita a avaliação do custo total do serviço, o preço de venda é calculado de forma que se adéqua a necessidade de um cliente classe A, considerando sempre a margem de lucro desejada pelos sócios, a empresa consegue cobrar desse cliente o valor de $\mathrm{R} \$ 2.500,00$, considerando também que esse valor é aplicado para uma decoração feita fora da região onde a empresa atua costumeiramente.

\subsection{CUSTEAMENTO POR CICLO DE VIDA DO PRODUTO (LIFE CYCLE COSTING)}

Dentro deste processo, os custos dos produtos começam a ser incorridos bem antes da fase inicial da produção, pois quando inicia o processo de produção, determinar possíveis reduções nos custos torna-se muito mais difícil para a empresa. Em outras palavras, do início do planejamento até apresentação final do produto e sua comercialização. Aplicabilidade: Por ser um método que identifica todos os custos do produto, desde o início da sua produção, no serviço de decoração infantil não será diferente, foram identificados todos os custos incorridos em uma decoração:

\subsection{CUSTO-META (TARGET COST)}

Nesse caso o custo alvo é a soma do custo de materiais, mão-de-obra e custo com as demais atividades relacionadas a preparação do produto. Os autores comentam ainda que em suma, o custo alvo ou custo-meta pode ser mostrado aritmeticamente como: CustoAlvo= Preço de venda menos Lucro desejado. Aplicabilidade: O conceito de custo meta é o preço estimado ou valor de mercado subtraído da margem de lucro desejada pelo empresário. Atualmente o valor de mercado do serviço de decoração infantil é $R \$ 550,00$, e os sócios da Still estimam uma margem de lucro de $R \$ 300,00$, então aplicando isso na fórmula teremos: Custo- meta/Custo-alvo= $550-300=250$. O custo máximo permitido através do cálculo do custo meta é $R \$ 250,00$.

\subsection{FORMAÇÃO DE PREÇOS BASEADA EM CUSTOS:}

A formação de preço baseada em custos da ênfase em dois conceitos importantes: · Margem de contribuição;

Valor presente.

Aplicabilidade: Preço de mercado para o serviço de decoração infantil $\mathrm{R} \$ 550,00$. Custos totais da empresa Still $\mathrm{R} \$ 1.434,96$, continuando com a margem de lucro desejada pelos sócios de $R \$ 300,00$, o preço com base nos custos seria de $\mathrm{R} \$ 1.735,00$.

\subsection{FORMAÇÃO DE PREÇOS BASEADA EM GASTOS MAIS MARGEM DE LUCRO:}

Nesse caso de formação de preço, os gastos são classificados em fixos e variáveis:

Gastos fixos: são aqueles que não se alteram de acordo com o volume de produção ou vendas.

Gastos variáveis: são os que variam proporcionalmente de acordo com o volume de produção e venda.

Aplicabilidade: Este método tem como base todos os gastos que a empresa tem para realizar o serviço ou confeccionar o produto. É uma formação de preço que considera que a empresa já elaborou seu orçamento e já estabeleceu o lucro desejado. Esse lucro pode ser relacionado de acordo com as vendas projetadas ou com o patrimônio líquido para obter retorno de todo investimento feito pela empresa.

$\mathrm{CPV}=$ Custos fixos + Custos variáveis $=$ $1262,96+172=1434,96$

Fórmula: Receita de vendas $-\mathrm{CPV}=$ Lucro bruto - Despesas operacionais $=$ Lucro Líquido $=550-1434,96=-884,96-0=R \$-$ 884,96

\subsection{ABORDAGEM RKW:}

Há algumas dificuldades práticas e limitações para o uso desse método:

Como encontrar o custo unitário do produto (CPV) no dia-a-dia;

Como encontrar as despesas operacionais por unidades; 
As oscilações no volume de produção e seus efeitos no custo fixo unitário não são considerados;

Os vários rateios necessários para alocar os custos fixos aos departamentos e destes aos produtos trazem consigo muitas distorções.

A equação da abordagem RKW para determinar o preço é : $P=C P V+D O+0,55 . P$

Onde,

$\mathrm{P}=$ preço; $\mathrm{CPV}=$ custo do produto vendido; $\mathrm{DO}=$ despesas operacionais; O,55.P= lucro desejado de $55 \%$ x preço

Aplicabilidade: $\mathrm{P}=\mathrm{CPV}+\mathrm{DO}+$ 0,55.P $\mathrm{P}=$ $1.436,96+0+0,55 . P$

$P=R \$ 2.609,01$

\subsection{CUSTEIO POR ABSORÇÃO}

Este método leva em consideração para base de cálculo, os custos fixos e variáveis e também as despesas fixas e variáveis.

Aplicabilidade:

Fórmula: $\mathrm{P}=\mathrm{CPV}+(-1,54 . \mathrm{P})=\mathrm{CPV}=$ $1.434,96=-260,90 \%$

Lucro/Prejuízo $=-884,96=-160,90 \% \mathrm{P}=$ $\mathrm{CPV}+(-1,60 . P)$

$P=1.434,96+(-1,60 . P) P=R \$-896,85$

\subsection{CUSTEIO VARIÁVEL}

Esse método de custeio é utilizado pelos gestores apenas para critério de análise, pois nele podem decidir se continuam a fabricar ou prestar aquele serviço, ou quanto devem produzir para que se obtenha o lucro desejado.

Aplicabilidade:

Fórmula: CV = Receita de vendas - impostos (custos variáveis + despesa variáveis) $\mathrm{CV}=$ $550,00-0-(172,00+0)$

$\mathrm{CV}=\mathrm{R} \$ 378,00$

\subsection{MARGEM DE CONTRIBUIÇÃO:}

Este método nos mostra que o preço de venda é composto basicamente pelo custo de aquisição, mão de obra, tributos e despesas sobre vendas, sendo reorganizados para o fim dessa abordagem. Os gastos variáveis são separados dos gastos fixos, subtraindo então da receita os gastos e despesas variáveis, chega-se ao resultado da margem de contribuição.

Fórmula:

$M C=P V-($ Custos variáveis + Despesas variáveis).

A margem de contribuição serve para cobrir custos e despesas fixas e ainda sobrar um resultado.

Aplicabilidade: Fórmula:

$\mathrm{MC}=$ preço de venda - impostos - ( custos variáveis + despesas variáveis ) $M C=550,00$ $-0-(172,00+0)$

$\mathrm{MC}=\mathrm{R} \$ 378,00$

\subsection{MARK-UP}

Segundo Megliorini (2007, p.180) "o Mark-up consiste em uma margem, geralmente expressa na forma de um índice ou percentual, que é adicionada ao custo dos produtos. Esse custo apresentará variações, dependendo do método de custeio utilizado (por absorção, variável, pleno etc.)".

Ainda segundo Megliorini (2007, p.181) "definido o custo, o preço de venda pode ser calculado da seguinte maneira":

Preço de venda = Custo / Mark-up ou

Preço de venda $=$ Custo $\times$ Mark-up

No entanto, deve-se retirar dos 100\% de receita as porcentagens referentes aos tributos, despesas (calculadas de acordo com o DRE do ano anterior) e a margem de lucro desejada, para por fim encontrar a taxa Mark-up. Como citado anteriormente existe o Mark-up divisor e multiplicador.

Formulas:

Mark-up Divisor $=(100 \%-x) / 100 \%=y$ Markup Multiplicador $=(1 / \mathrm{y})=\mathrm{z}$ Aplicabilidade:

Preço de venda $R \$ 550,00=100 \%$ Custos Fixos $=R \$ 1.262,96=229,63 \%$ Custos Variáveis $=R \$ 172,00=31,27 \%$ Margem de Lucro $=55 \%$

$100 \%-229,62 \%-31,27 \%-55 \%=-215,90 \%$

Calculando o preço de venda com o markup divisor e multiplicador teremos: Markup Divisor $=100 \%-(-215,90 \%) / 100 \%=315,90$ / $100 \%=3,16$ 
Custos / markup divisor $=1.434,96 / 3,16=$ $\mathrm{R} \$ 454,10$. Markup Multiplicador $=1 / 3,16=$ 0,31646

Custos $\times$ Markup multiplicador $=1.434,96 \times$ $0,31646=\mathrm{R} \$ 454,10$

\subsection{PREÇO DE VENDA ORIENTATIVO}

Segundo Wernke (2005, p. 147) "esta modalidade de precificação é mais utilizada pelas entidades que têm o poder para impor preços ao mercado consumidor".

Essas entidades são no caso, empresas que conseguem cobrar o preço desejado por não existir concorrência, ou produtos similares, por oligopólios ou monopólios que praticam o preço que Ihes são convenientes, e empresas que geralmente já incluem no preço de venda o valor do lucro desejado.

Preço de venda orientativo $=$ Custo unitário $\mathrm{x}$ Markup Aplicabilidade: 1.434,96 × 0,31646 = $\mathrm{R} \$ 454,10$

\section{CONSIDERAÇÕES FINAIS}

As aplicações foram feitas com base no valor de $\mathrm{R} \$ 550,00$, que é o preço praticado pela empresa em um bairro da zona sul de São Paulo.

Os métodos custeamento por ciclo de vida do produto e custo-meta evidenciam o custo total e o custo máximo que a empresa pode ter para realização do serviço, e a margem de

\section{REFERÊNCIAS}

[1]. HANSEN, Don R. e MOWEN, Maryanne M. Gestão de Custos - Contabilidade e controle. São Paulo: Pioneira Thomson Learning, 2001

[2]. HERNANDEZ PEREZ JUNIOR, JOSÉ. Gestão estratégica de custos / José Hernandez Perez Junior, Luís Martins de Oliveira, Rogério Guedes Costa. - 6. Ed. - 2. reimpr. - São Paulo : Atlas, 2010.

[3]. LAKATOS, EVA MARIA. Fundamentos de metodologia cientifica / Marina de Andrade Marconi, Eva Maria Lakatos. - 6. ed.- 6. reimpr. São Paulo : Atlas 2008

[4]. MEGLIORINI, EVANDIR. Custos: análise e gestão / Evandir Megliorini. - 2. ed. - São Paulo : Pearson Prentice Hall, 2007.

[5]. WERNKE, RODNEY. Análise de custos e preço de venda: (ênfase em aplicações e casos nacionais) contribuição evidencia o quanto a empresa disponibiliza para cobrir o os custos e despesas fixas, ação que não seria boa, pois, como mostra o quadro acima, os custos fixos da empresa estão bem altos.

Os piores métodos a serem praticados pela empresa são a formação de preço baseada em gastos mais margem de lucro e o custeio por absorção, pois ambos apresentam prejuízo. E os melhores métodos são a formação de preço baseada em custos e o método RKW, pois são os que apresentam os maiores preços de venda.

Embora a precificação seja uma tarefa bem complexa, os gestores e proprietários de empresas de serviço devem dar mais importância no momento de

determinar o preço de venda, pois esse "detalhe" indica o rumo que a empresa pode seguir.

Conclui-se então que, a empresa precisa reduzir seus custos para continuar prestando o serviço de decoração infantil nessa região, ou ter no mínimo quatro decorações por mês para ter um lucro de $R \$ 280,00$. E a empresa pode também expandir seu atendimento para regiões mais nobres de São Paulo, podendo aplicar valores maiores de acordo com a necessidade de um cliente classe $A$, fazendo com que os preços aplicados cubram todos seus custos e despesas e a empresa tenha sempre bons lucros e continue atuando no mercado de decoração infantil.

[6]. / Rodney Wernke. - São Paulo : Saraiva, 2005 .

[7]. KRUGMAN, PAUL R., 1953.- Introdução à economia / Paul Krugman, Robin Wells ; [tradução Helga Hoffman]. - 3. ed. - Rio de Janeiro : Elsevier, 2015.

[8]. COMO REALIZAR A FORMAÇÃO DE PREÇO PARA SERVIÇOS. Disponível em: https://blog.luz.vc/como-fazer/formacao-de-precopara-servicos/. Acesso em 13 de novembro de 2017.

[9]. PREÇO DE VENDA NA PRESTAÇÃO DE SERVIÇOS. Disponível em www.sebrae.com.br autor: Luis Alberto Fernandes Lobrigatti - consultor da U.O.O.E do Sebrae - SP. 


$$
\text { Alutary }
$$




\section{ADRIANO CARLOS MORAES ROSA}

É aluno regular do Programa de Doutorado em Engenharia de Produção da Universidade Federal de Itajubá - UNIFEI (2012). Possui Licenciatura Plena em Administração pelo Programa Especial de Formação Pedagógica de Docentes pelo Centro Estadual de Educação Tecnológica - CEETEPS (2012). É mestre em Gestão e Desenvolvimento Regional (2007) e Pós Graduado - MBA em Gerência de Produção e Tecnologia (2003) pela UNITAU - Universidade de Taubaté (2003). Possui graduação em Automação de Escritórios e Secretariado pela FATEC - Faculdade de Tecnologia de Guaratinguetá (2000), e tem experiência na área de Educação, com ênfase em Administração e Logística (Transportes e Armazenamento de Produtos Perigosos). É professor universitário desde 2005 atuando na FATEC Guaratinguetá nos cursos de Gestão Empresarial/ Processos Gerenciais, Logística, Gestão Financeira e Informática. Em todos os cursos ministra aulas de Administração Geral.

\section{ALAN AMORIM DE JESUS}

Técnico em Logística pela Etec Embu Técnólogo em Logística pela Fatec Zona Sul

\section{ALEXANDRE GARCIA DE OLIVEIRA}

Possui graduação em Processamento de Dados pela Faculdade de Tecnologia da Baixada Santista (Santos/SP) (2006), graduação em Matemática pela Universidade de São Paulo (2012) e mestrado em Matemática Aplicada pela Universidade de São Paulo (2015). Atualmente é professor - Fatec Rubens Lara. Tem experiência na área de Ciência da Computação, com ênfase em programação funcional e em Matemática Aplicada na área de Análise Numérica.

\section{ANDERSON MARQUES DOS SANTOS}

Atualmente cursando tecnólogo em Gestão Empresarial pela FATEC Zona Leste, com previsão de término para o final de 2018. Nível básico de entendimento dos idiomas inglês e espanhol. Experiência de 7 anos no ramo do comércio em uma empresa atacadista, e atualmente Conferente de expedição pela mesma. Dinâmico, Comunicativo e Proativo.

\section{ANTONIO WELLINGTON SALES RIOS}

Mestre em Engenharia Eletrônica e Computação - Instituo Tecnológico de Aeronáutica. Engenheiro de Infra-estrutura Aeronáutica - Instituto Tecnológico de Aeronáutica. Professor da Faculdade de Tecnologia de São José dos Campos das disciplinas: Arquitetura e Organização de Computadores, Fundamentos de Redes de Computadores, Tecnologia e Ambiente e Meio Ambiente e Saúde. Professor da disciplina Ciências Ambientais e das Águas da Faculdade de Tecnologia de Jacareí. Sócio diretor das empresas Micro Assist Infomática Ltda e Actie Ltda com sede em São José dos Campos. Doutorado não concluído Engenharia Mecânica: Transmissão e Conservação de Energia, Educação e Meio Ambiente. Ex diretor da FATEC Guaratinguetá, Ex diretor da FATEC São José dos Campos e Ex Coordenador dos cursos de Estruturas Leves, Automação Aeronáutica e Projetos de Estruturas Aeronáuticas da FATEC São José dos Campos.

\section{ARMINDO APARECIDO EVANGELISTA}

Mestre em Controladoria e Contabilidade Estratégica pela FECAP e graduado em Ciências Contábeis pela Universidade Paulista. Consultor de Empresas, Conteudista em EAD; Professor de Ensino Superior dos cursos de Graduação em Ciências Contábeis e Administração de Empresas, Tecnólogos e Pós-Graduação em Controladoria, Auditoria, Finanças \& Banking, Gestão Pública e Gestão de Negócios. Tanto nos cursos presenciais e em EaD. Coordenador acadêmico adjunto do curso de Ciências Contábeis. Vivência profissional (supervisão e coordenação) nas área de Controladoria: Contabilidade Societária, Contabilidade de Custos, 
Orçamento e Planejamento Empresarial, atuando em empresas nacionais e multinacionais dos segmentos: indústria e prestação de serviços.

\section{CLAUDIO MELIM DONA}

Mestrado Profissional em Gestão e Tecnologia em Sistemas Produtivos (Centro Paula Souza FATEC); MBA Executivo em Gestão Empresarial (Centro Paula Souza - FATEC); Pós Graduação em Marketing (Cásper Líbero) e em Gestão e Ambiente de Trabalho (FGV) em instituições de primeira linha; Especialista ISO 9001 (SGQ) e ISO 20000; Certificação ITIL, Cobit, SoX, BPM, BSC, ISO 20000, ISO 27001 (SGSI); Planejamento, implantação e gestão de grandes projetos de TI (Help Desk, Service Desk e Governança Corporativa); Mais de 30 projetos executados com sucesso para grandes Clientes e 14 publicações científicas para a área de TI, dentre livros e artigos .

\section{CLAYTON GERBER MANGINI}

Mestre em Gestão e Tecnologia em Sistemas Produtivos pelo Centro Paula Souza (Centro Paula Souza); Graduando como Tecnólogo em Gestão Portuária pela FATEC BS; Graduado como Tecnólogo em Logística pela FATEC BS; Graduado pela Faculdade de Farmácia e Bioquímica da Universidade Católica de Santos; Habilitado em Farmácia Industrial pela Faculdade Oswaldo Cruz; Especialização em Administração Industrial pela Fundação Carlos Alberto Vanzolini (USP). MBA em Gestão Empresarial com Ênfase em Logística Empresarial pela FGV; Docente da Disciplina Assuntos Regulatórios na Cadeia Logística do Instituto de Ciência, Tecnologia e Qualidade Industrial (ICTQ); Coordenador de Cursos e Docente da Faculdade Innovare e do Instituto Racine.

\section{CRISTIANE DA SILVA}

Estudante do Curso de Logística da Faculdade de Tecnologia da Zona Leste - FATEC-ZL em São Paulo-SP. Profissional da Empresa VIP Transportes Urbanos, trabalhando com Logística, Operações e Transportes.

\section{CRISTIANE MARISA DOS SANTOS}

Possui graduação em Pedagoga pela Universidade Paulista (UNIP) e pós graduação em Educação Especial com Ênfase em Deficiência Intelectual pela Faculdade da Aldeia de Carapicuíba. Atuante na área da educação desde 1998.

\section{DEIVID MÁRLON FERNANDES DA COSTA}

Graduado em Tecnologia em Gestão Ambiental, Técnico de Meio Ambiente e formando em Tecnologia em Geoprocessamento, já atuou profissionalmente como Agente Comunitário de Saúde. Na área de Geoprocessamento, participou de diversos projetos de restituição e classificação de base cartográfica digital vetorial a partir da interpretação de mosaicos de imagens de satélites. Tais projetos foram calcados em normativas como a Especificação Técnica para a Estruturação de Dados Geoespaciais Vetoriais e a Especificação Técnica para a Aquisição de Dados Geoespaciais Vetoriais. Além disso, também possui experiência com modelagem de banco de dados espacial. Interessa-se por Geotecnologias e a aplicação destas na Administração Pública.

\section{EDILSON SILVA ARAUJO}

Cursando o 4ํㅗㄹ semestre do curso de Gestão Empresarial na Fatec Rubens Lara, nível básico no idioma inglês. Conhecimento intermediário no Pacote Office e perfil de profissional empenhado, comprometido, com facilidade para trabalhar em equipe e de rápida adaptação. Experiência como sócio proprietário da MERCEARIA LEIRIA LTDA no período de 1989 - 2017. 


\section{ERIK MASSAHIRO SATO}

Técnico Eletrônico pela Instituição "Everardo Passos" (ETEP), graduado em Logística pela Faculdade de Tecnologia de São José dos Campos - FATEC.

\section{FERNANDO MENDES TORRES}

Fernando Mendes Torres, 29 anos, Bacharel em Administração de Empresas pela Universidade Paulista (UNIP), graduado em Logística pela Faculdade de Tecnologia de São José dos Campos - FATEC.

\section{FULVIA CAROLINA CORREA}

Possui graduação em Computação pela Universidade de Taubaté (2002) e especialização em Produção pela Unesp (2016). Atualmente é Professora de Nível Superior no Centro Paula Souza (Fatec Guaratinguetá). Tem experiência na área de Tecnologia da Informação, Materiais e Produção. Atualmente desenvolve pesquisa voltada para jogos empresariais, dinâmicas em grupo e atividades lúdicas dentro de sala de aula.

\section{GEISY ANNY VENÂNCIO}

Natural de Manaus-AM, professora efetiva do Instituto Federal de Educação, Ciência e Tecnologia do Amazonas. Mestre em Design pelo Programa de Pós-Graduação em Design da Universidade Federal do Paraná . Especialista em: Design Instrucional para EaD Virtual pela Universidade Federal de Itajubá Educação a Distância, com habilitação em Tecnologias Educacionais, pelo Instituto Federal de Educação, Ciência e Tecnologia do Paraná; e em Planejamento, Implementação e Gestão da EaD, pela Universidade Federal Fluminense . Bacharel em Desenho Industrial com habilitação em Projeto do Produto, pela Universidade Federal do Amazonas . Em Cooperação Técnica com o Instituto Federal de Educação, Ciência e Tecnologia de Minas Gerais, Campus Santa Luzia desde junho/2018.

\section{HENRIQUE MENEZES NOGUEIRA}

Natural de Manaus-AM, graduando em Tecnologia em Logística pelo Instituto Federal de Educação, Ciência e Tecnologia do Amazonas - IFAM, Campus Manaus Distrito Industrial. Técnico em Eletrotécnica também pelo Instituto Federal de Educação, Ciência e Tecnologia do Amazonas, Campus Manaus Centro. Linhas de pesquisa:Logística empresarial e Logística Reversa.

\section{IEDA RIBEIRO}

Economista, pós-graduada em Design Thinking pelo IED (BCN) e Mestrado em andamento na área de Gestão Estratégia de TI pelo Centro Estadual de Educação Tecnológica Paula Souza. Larga experiência em Estratégia de Marketing, análise de jornada e experiência do cliente final e Canal. Desenvolvimento de Projetos nas áreas de Marketing intelligence, Planejamento de Marketing/Comunicação (online e off-line), ContactCenter/Customer Service e Pesquisas de Satisfação com Cliente. Desenho e implementação de Programas de Relacionamento para clientes B2B: desde estruturação de banco de dados, uso de ferramentas de inteligência de marketing e definição da estratégia de relacionamento em todos os pontos de contato (time de conta, digital ou evento. Atualmente trabalha no YOUSE seguros, na área de Customer Experience. Trabalhou em empresas como Microsoft, IED, Teleperformance e Grupo VR.

\section{ISABEL CRISTINA MOTA}

Mestre em Administração na UMESP São Bernardo do Campo, MBA Executivo em Marketing de Serviços pela ESPM, Pós Graduação em Planejamento Estratégico de Turismo pelo SENAC -SP, graduação em Comunicação Social - Publicidade e Propaganda pela Universidade de 
Mogi das Cruzes. Docente há 20 anos na área de Marketing em instituições de ensino particulares e públicas(FATEC). Atualmente é coordenadora do Tecnólogo em Fotografia e cursos de pós graduação no SENAC-SP e professora de pós graduação em cursos de Gestão de Marketing. Tem experiência na área de Comunicação, atuando principalmente nos seguintes disciplinas: estratégias de marketing em organizações contemporâneas.

\section{ISIS EMANUELLE CORREIA DA SILVA}

Cursando o $3^{\circ}$ semestre de Gestão Financeira. Atualmente CEO da empresa Correia Maciel Assessoria e Consultoria Financeira.

\section{JAMILE BRANDÃO SILVA}

Graduanda em ciências contábeis na Universidade nove de Julho. Atualmente, atua na área contábil.

\section{JESSICA MAKI HIRAKAWA TERRA}

Graduanda em Tecnologia em Logística pela Faculdade de Tecnologia de Mogi das Cruzes (Fatec-MC). Atualmente, atua como Agente de Atendimento Bilíngue, em um dos maiores Operadores Logístico do Brasil. Desenvolveu trabalhos de pesquisa acadêmica relacionado a cadeia de distribuição de medicamentos.

\section{JOSÉ MANOEL SOUZA DAS NEVES}

Doutor em Ciências pelo programa de pós graduação em Engenharia Mecânica (Gerencia de Produção) da Faculdade de Engenharia de Guaratinguetá - UNESP (2011). Mestre em Engenharia (Engenharia de Produção) pela Escola Politécnica - USP (1999). Graduado em Tecnologia em Construção Civil pela FATEC São Paulo do Centro Paula Souza (1977). Atualmente é Professor do Ensino Superior III da Faculdade de Tecnologia de Guaratinguetá FATEC, do Centro Paula Souza. Professor do Programa de Mestrado Profissional em Gestão e Tecnologia em Sistemas Produtivos do Centro Paula Souza. Professor de cursos de pósgraduação lato sensu. Publicou trabalhos em anais de eventos. Membro do corpo editorial da Revista Científica On-line Tecnologia, Gestão e Humanismo da FATEC Guaratinguetá. Participou de eventos no Brasil e no exterior. Orientou Trabalhos de Graduação e de Pós Graduação nas áreas de administração e engenharia de produção. Atua nas áreas de engenharia de produção e de administração, com ênfase em qualidade, fatores organizacionais, dimensões competitivas da manufatura, inovação e empreendedorismo.

\section{JULIANE DOS SANTOS DA SILVA}

Cursou o $1^{\circ}$ semestre de Gestão Financeira. Atualmente cursa o $3^{\circ}$ semestre de Logística.

\section{JULIO CESAR APARECIDO DA CRUZ}

Mestrado em Gestão e Tecnologia de Sistemas Produtivos, Pós-graduado em Administração Industrial e Bacharel em Administração de Empresas. Especialista nas áreas de Planejamento de Produção e Suprimentos, Gestão da Demanda, Operações de Centro de Distribuição e Supply Chain. Possui 27 anos de experiência profissional adquirida em empresas de grande porte como Siemens, Sabó, Tower Automotive, DHL e CAV Sul. Responsável por operações de Centro de Distribuição, Logística In Plant e Packing Center. Onwership no start up de novas operações, shutdown de operações existente, implantação de Gestão Integrada da Cadeia Logística (GICL), projetos e desenvolvimento de novos negócios logísticos. 


\section{JULIO CESAR FERREIRA DOS PASSOS}

Mestre em Engenharia Civil pela Universidade Estadual de Campinas (UNICAMP), Especialista em Engenharia de Produção pela Pontífice Universidade Católica de Minas Gerais, Especialista Em Teorias, Práticas e Métodos para o Ensino a Distância pela Universidade Virtual do Estado de São Paulo, Tecnólogo em Logística pela Faculdade de Tecnologia e Graduado em Matemática pela Universidade Anhanguera. Possui experiência como Analista, Supervisor e Consultor nas áreas de Gestão e Engenharia e, na área acadêmica, como mediador pedagógico em cursos de graduação em Engenharia de Produção.

\section{KATIA CRISTINA MANTOVANI}

Possui graduação em Licenciatura Em Ciências Exatas pela Universidade de São Paulo e em Bacharelado em Estatística pela UFSCAR, fez especialização em Matemática e Estatística pela Universidade Federal de Lavras e Mestrado em Educação pela Universidade Estadual Paulista Júlio de Mesquita Filho Lecionou as disciplinas de Matemática II e Estatística na Faculdade de Ciências e Letras na UNESP-ARARAQUARA e lecionou as disciplinas de Cálculo Numérico, Matemática, Estatística e Metodologia do Trabalho Científico na Faculdade da Fundação de Ensino de Mococa. Atuou durante 2 anos na Faculdade de Tecnologia de Mococa - FATEC. Tem experiência na área de Probabilidade e Estatística e em diversos ramos do Ensino de Matemática e nas diversas aplicações e Estatística, atuando principalmente nos seguintes temas: Cálculo Financeiro, HP 12C e Estatística e atuou como coordenadora de extensão da Faculdade de Ensino de Mococa-FAFEM. Atualmente é professora da FATEC Guaratinguetá, lecionando as disciplinas de Matemática Discreta, Matemática e Estatística.

\section{KELI CRISTIANE VIDO}

Dezesseis anos de experiência nas diversas áreas de recursos humanos como: RS. (processos de headhunter); plano de carreira e mentoria para executivos; cargos e salários / benefícios corporativos; treinamento e desenvolvimento; avaliação de desempenho; expatriados e consultoria interna e externa de rh. Mentoria para startups: elaboração de business plan, processo de criação, desenvolvimento e refinamento de soluções tecnológicas, elaboração de estratégias de mercado, auditoria de implantações e prestações de serviços e capacitação de pessoal. Vivência como docente nos cursos de bacharelado; tecnólogos e pós-graduação: Administração; Administração com enfase em comércio exterior, Ciências Contábeis; Tecnólogos em: RH, Gestão Comercial, Sistemas de Informação, Gestão Financeira, Hotelaria, Gastronomia e Marketing; MBA em gestão de pessoas; projetos e controladoria; Conteudista da disciplina Saúde, Segurança e Meio Ambiente / Recrutamento e Seleção; Revisora das disciplinas de gestão humano do curso de Administração;Tutora dos cursos de graduação a distância: Tecnólogo em Recursos Humanos e Administração; Orientadora de TCC dos cursos de bacharelado e tecnólogos. Elaboração de projeto pedagógico; programa de estágio; planos de ensino e ementário, além do cadastramento de curso, junto ao MEC e acompanhamento das visitas para autorização e reconhecimento; Coordenação da faculdade aberta para comunidade; gestão de projetos de extensão, balizados pelas práticas de recursos humanos; supervisão do programa de estágio; seleção de professores; criação de horário;Sólida experiência na gestão de projetos voltados à comunidade, ONGs e Oscips e instituições públicas. Capacitação de docentes da secretária estadual de educação; gestão dos projetos sociais e desenvolvimento educacional nas creches Obra Koping e escolas públicas da região Oeste de São Paulo. Formada em Administração de Empresas, pós-graduação em: RH; Marketing; Didática e Metodologia do Ensino Superior; Psicopedagogia e mestrado em Psicologia; Doutora em Administração pela Universidade Presbiteriana Mackenzie. Pesquisas sobre o estresse laboral com a Universidade da Fronteira (Uruguai e UBA) e inclusão de pessoas com deficiência junto as empresas da região Oeste de São Paulo; Etarismo, envelhecimento e aposentadoria com o núcleo de diversidade da Universidade Presbiteriana Mackenzie. Participação do Centro de 
Tecnologia e Inovação do Centro Paula Souza como orientadora dos projetos de pesquisa do curso Tec, em logística e projeto de extensão Escritório de Carreiras.

\section{LUCAS FIGUEIREDO}

Desenvolvedor Front-end recém formado em Tecnologia em Sistemas para Internet pela Fatec Rubens Lara.

\section{LUCAS SANTANA FREIRES}

Graduando em Tecnologia em Logística pela Faculdade de Tecnologia de Mogi das Cruzes (Fatec-MC). Já atuou como Monitor de Informática na Faculdade de Tecnologia de Mogi das Cruzes (Fatec-MC) e Aprendiz na Empresa Brasileira de Correios e Telégrafos (Correios). Atualmente, atua como estagiário no setor administrativo na Prefeitura Municipal de Mogi das Cruzes. Desenvolveu trabalhos de pesquisa acadêmica relacionado a cadeia de distribuição de medicamentos.

\section{LUCIANO GERALDO DA SILVA}

Estudante do Curso de Logística da Faculdade de Tecnologia da Zona Leste - FATEC-ZL em São Paulo-SP. Profissional Responsável pela conferência do recebimento/identificação/armazenagem e carregamento do produto separado e paletizado, contagens cíclicas diárias no setor de alto risco, inventários periódicos; -Experiência em gestão de pessoas, organização e limpeza do setor evitando acidentes e avarias. Sempre focado nos processos de melhorias. -Experiência em centro de distribuição de alto giro. Conhecimento em WMS e uso de coletor de dados portátil (RF).

\section{LUCIANO GONÇALVES COSTA}

Técnico em Operações Comerciais, pelo IFSP Suzano e Técnico em Finanças, pela ETEC Prof. Camargo Aranha. Atualmente, graduando do curso de Tecnologia em Gestão Empresarial, pela FATEC Zona Leste. Possui experiência com atendimento ao cliente, no ramo de Serviço de Atendimento ao Consumidor (SAC), e atualmente Estagiário Administrativo na FATEC São Paulo.

\section{LUCINEIDE BISPO DOS REIS LUZ}

Mestranda em Ciências Contábeis na FECAP. Possui graduação em Ciências Contábeis pela Universidade Presbiteriana Mackenzie (2001). Pós-graduação lato sensu em Controladoria pela Instituição Faculdade São Luís no período de 2002 a 2004. Pós-graduação MBA em Controladoria, Finanças e Auditoria pela Escola de Administração de Empresas da Fundação Getúlio Vargas (FGV), no período de 2007 a 2009. Pós-graduação em Docência universitária pela Universidade Nove de Julho, no período de 2011 a 2013. Pós-graduação em Formação Capacitação de Docentes de Administração pela Universidade de São Paulo (USP) - Ribeirão Preto, no período de 2012 a 2014. Pós Graduação em Gestão Pública Municipal pela Universidade Federal de São João Del-Rei, UFSJ, São Joao Del Rei (UFSJ), no período de 2014 a 2016;Contadora e Professora de Contabilidade, Análise de Balanço, Controladoria e Custos da Universidade Nove de Julho (UNINOVE)

\section{LUIZ ANTONIO TOZI}

Doutor em Engenharia Mecânica- Produção pelo Instituto Tecnológico de Aeronáutica (ITA); Mestre em Engenharia de Infraestrutura Aeronáutica pelo Instituto Tecnológico de Aeronáutica(ITA); Graduação em Engenharia Naval e Oceânica pela Universidade de São Paulo (USP); Vice-Diretor Superintendente do Centro Paula Souza; Sócio Diretor de empresa distribuidora de chapas e perfis de alumínio; Sócio Diretor de empresa Hoteleira - Pousada Bosque das Araucárias -Campos do Jordão; É professor pleno dos cursos de Logística e 
Gestão da Produção Industrial da Faculdade de Tecnologia de São José dos Campos (FATEC), professor de Pós Graduação da FGV; Coordena o Grupo de Pesquisa: Núcleo de Estudos em Sistemas de Transporte (NEST) do Instituto Tecnológico de Aeronáutica (ITA).

\section{MAICK ROBERTO LOPES}

Graduado em Engenharia de Produção Mecânica pela Universidade Braz Cubas (2005), especialista em Administração Industrial pela Fundação Vanzolini - USP (2008) e Mestre em Engenharia de Produção pela Universidade Metodista de Piracicaba (UNIMEP). Atualmente é Professor nos cursos de Graduação e Pós-Graduação no Centro Paula Souza - Fatec Sebrae e Fatec Mogi da Cruzes, Universidade Cidade de São Paulo (UNICID) e Faculdade Sul Brasil (FASUL). Leciona nos cursos de Administração, Engenharia, Comércio Exterior, Logística, Marketing, Processos Gerenciais e Gestão de Negócios e Inovação. Tem experiência na área de Engenharia de Produção, com ênfase em Gerência de Produção e Gestão de Planejamento da Produção e Supply Chain. Atua principalmente nos seguintes temas: Logística, Gestão da Produção, Gestão de Materiais e PCP.

\section{MARCELO DUDUCHI FEITOSA}

Graduado na área de Informática pela FATEC-SP , especialista em Automação Industrial, mestre e doutor pela USP em Psicologia (Neurociências e Comportamento e Psicologia Experimental). Docente por mais de 25 anos, atualmente é professor do Depto de TI da FATEC-SP e no Mestrado Profissional de Gestão e Tecnologia em Sistemas Produtivos do CEETEPS. Também atua na USJT. Tem experiência na área de Computação, Psicologia, Educação e Neurociências onde pesquisa os processos de tomada de decisão e gestão de Tecnologia da Informação, os processos de desenvolvimento de software, a interação humano-computador além de outros estudos em Ciência Cognitiva.

\section{MARIA JULIANA GOES COELHO DA CRUZ}

Mestranda em Engenharia Civil pela Universidade Estadual de Campinas (UNICAMP), Especialista em Metodologia do Ensino Superior pela Faculdade Educacional da Lapa (FAEL), Bacharelada em Engenharia Civil pelo Centro Universitário Jorge Amado (UNIJORGE) e Bacharelada em Design pela Faculdade da Cidade do Salvador. Possui experiência em acompanhamento e assistência técnica de obras de engenharia civil e, na área acadêmica, é docente do Curso Técnico em Edificações do Instituto Data Brasil - EDUTEC. Também é voluntária no Instituto Histórico de Blumenau.

\section{MARIANA MARTINS DE MESQUITA}

Graduanda em Ciências Contábeis na universidade Nove de Julho - UNINOVE. Estagiária em um escritório de contabilidade no departamento contábil. Curso Técnico de Administração com ênfase em contabilidade no ano de 2014.

\section{MARILIA MACORIN DE AZEVEDO}

Doutora em Engenharia pela POLI - Universidade de São Paulo (USP). Mestre em Qualidade pela Universidade de Campinas (UNICAMP). Graduada em Tecnologia de Processamento de Dados pela Faculdade de Tecnologia de São Paulo (FATEC SP). Foi vice-diretora, diretoria acadêmica das Faculdades e CET Radial e Reitora de seu sucedâneo, o Centro Universitário Radial. Realiza pesquisas na área de Gestão da Qualidade, Engenharia e Ciência de Serviços, Gestão Estratégica da TI, Gestão e Avaliação da Educação Profissional e uso das Tecnologias na Educação. Atualmente é professora Pleno da Faculdade de Tecnologia de São Paulo, professora permanente do Mestrado Profissional em Gestão e Tecnologia em Sistemas Produtivos e do Mestrado Profissional em Gestão e Desenvolvimento da Educação Profissional - ambos do Centro Estadual de Educação Tecnológica Paula Souza, participando das disciplinas: Inovação e Competitividade Sistêmica; Gestão Estratégica de TI, Gestão da 
Qualidade, Gestão de Sistemas e Avaliação da Educação Profissional, entre outras. Possui 30 anos de experiência acadêmica como professora universitária além de experiência com desenvolvimento de sistemas e gestora na área de TI.

\section{MARISTELA FREITAS}

Formada em Logística pela Faculdade do Estado de São Paulo - FATEC - Mauá.

\section{MATHEUS AUGUSTO DE LIMA FARIA}

Cursando ensino superior tecnológico em Gestão Financeira na Fatec Guaratinguetá. Especializado em soldagem pelo Senai - cruzeiro 2018

\section{MAURÍCIO FARIA NOGUEIRA}

Formado em Logística pela Faculdade de Tecnologia Jessen Vidal de São José dos Campos (2015);

Cursando Gestão da Produção Industrial na FATEC SJC (2016 - 2019); 5 anos de experiência na área de Logística Industrial de uma multinacional, fabricante de aeronaves em São José dos Campos.

\section{MAYCON DOUGLAS DO NASCIMENTO ZANGRANDI}

Aluno da FATEC Guaratinguetá

\section{MOACIR FREITAS JUNIOR}

Mestre em Engenharia de Produção pela UNIP, Pós-graduado em Logística Empresarial pela UASP, em Gestão de RH pela UCAM, em Formação Profissional pela Unia e em Sistemas pela Unisanta. Graduado em Administração de Empresas pela UNICID. Professor titular da FATEC da Zona Sul e da ETEC HAS, unidades do Centro Paula Souza, atuando também na graduação e Pós-graduação da UNISANTARITA.

\section{NAPOLEAO VERARDI GALEGALE}

Doutor em Controladoria e Contabilidade pela FEA/USP, mestre em Engenharia de Produção pela POLI/USP, graduado em Ciências Contábeis pela FEA/USP e em Processamento de Dados pela Faculdade de Tecnologia de São Paulo. Professor e pesquisador do Centro Paula Souza e da PUC-SP. Editor da Revista CAFI - Contabilidade, Atuária, Finanças \& Informação. Líder do Grupo de Pesquisa em Gestão Estratégica da Tecnologia da Informação, cadastrado no CNPq. Autor de livros e artigos acadêmicos no tema da tecnologia da informação. É consultor de empresas com experiência profissional nas áreas de Administração e Engenharia de Produção, com ênfase em tecnologia da informação, atuando em: Governança Corporativa e da Tecnologia da Informação, Sistemas de Informações para Tomada de Decisões, Sistemas Integrados de Gestão, Auditoria de Sistemas, Segurança da Informação, Análise de Risco, Banco de Dados, dentre outros.

\section{NATÁLIA MARCELINO RAMOS}

Formada em Logística pela Faculdade de Tecnologia Jessen Vidal de São José dos Campos (2012-2015); Formada em Gestão da Produção Industrial pela Faculdade de Tecnologia Jessen Vidal de São José dos Campos (2015-2018); Experiência de 04 anos na área de transporte de cargas aéreas. 


\section{NATAN DE PAULA SANTOS}

Cursando o $3^{\circ}$ semestre de Gestão Financeira. Atualmente segue os estudos na área.

\section{PATRÍCIA PINTO}

Graduanda do Curso de Ciências Contábeis pela UNINOVE - Universidade Nove de Julho. Trabalha há quase 17 anos na área contábil. Já atuou como analista contábil em empresa de contabilidade. Atualmente, atua como analista fiscal.

\section{PAULO ANDRÉ DE OLIVEIRA}

Possui graduação em Ciências Econômicas, mestrado e doutorado pela Universidade Estadual Paulista Júlio de Mesquita Filho (2007). Atualmente é professor da Faculdade de Tecnologia de Botucatu. Tem experiência na área de Economia, com ênfase em Economia Agrária e métodos quantitativos aplicados a gestão.

\section{PAULO VITOR HOMEM DE MELLO KUSPLICA}

Estudante, cursando o último semestre do curso de Sistemas para Internet na Fatec Rubens Lara.

\section{PERI DA SILVA SANTANA}

Mestre em Engenharia da Produção, Pós-Graduado e Especialista em Estratégia e Gestão Estratégica, Bacharel e Graduado em Administração e com Licenciatura em Sociologia, Licenciado em Estudos Sociais. Aluno especial nas disciplinas da Universidade de São PauloUSP, no Programa de Mestrado em Administração/FEA-USP na disciplina: GQVT - Gestão da Qualidade de Vida no Trabalho, no Programa de Mestrado em Comunicação/ECA-USP na disciplina: Aventura Estética da Publicidade e na USP-Leste EACH no programa de Gestão Têxtil na disciplina: Gestão e Modelagem Matemática, Pós-Graduado-Lato-Sensu em Administração Estratégica Empresarial, extensão pela Fundação Getúlio Vargas FGV-EAESP em Gestão Estratégica, Escola Superior de Propaganda e Marketing - ESPM em CRM (Customer Relationship Management), Relacionamento com o Cliente, Fundação Vanzolini em FMEA (Failure Modes and Effects Analysis), Análise do Tipo e Efeito de Falha, Fundação Faculdade Trevisan em Planejamento Estratégico, Instituto e Fundação IPEC em Didática do Ensino Superior. Atualmente é Pesquisador, Professor/Docente do CEETEPS - Centro Estadual de Educação Tecnológica Paula Souza nos cursos Bacharelado/Graduação, Formação Específica e Tecnologia do departamento de Ciências Gerenciais. Tem experiência e vivência na área de Administração e Gestão, processos gerais de gestão, auditoria e glosa, logística, departamento financeiro, automação bancária, indústria, gráfica. Atuando principalmente nos seguintes temas de Administração, Estratégia, Comunicação, Planejamento, Logística e Gestão.

\section{PIETRA MONTEIRO DE OLIVEIRA SILVA}

Cursando o $3^{\circ}$ semestre do curso de Gestão Financeira. Atualmente estagiária da prefeitura Municipal de Aparecida.

\section{RAFAEL ROLANDO MITTEENN MUÑOZ}

Formado em Logística pela FATEC Mauá 


\section{REINALDO FAGUNDES DOS SANTOS}

Possui pós-doutorado em Engenharia Mecânica na área de Produção pela Universidade Estadual Paulista - Campus Guaratinguetá - UNESP (2016), doutorado em Engenharia Aeronáutica e Mecânica pelo Instituto Tecnológico de Aeronáutica - ITA (2010), mestrado em Engenharia Aeronáutica e Mecânica pelo Instituto Tecnológico de Aeronáutica - ITA (2005), graduação em Engenharia Industrial Mecânica pela Escola de Engenharia Industrial de SJC (1982). Atualmente é coordenador e professor do Curso de Logística e professor do curso de Gestão da Produção Industrial da Faculdade de Tecnologia (FATEC) - Campus São José dos Campos. Tem experiência nas áreas de Engenharia de Produção e Logística com ênfase em Tecnologia da Informação e Comunicação. Sua área de pesquisa inclui Gerenciamento da Cadeia de Suprimentos, Logística, Produção, Manufatura Enxuta, Teoria das Restrições, Tecnologia da Informação e Comunicação, Pesquisa Operacional, Estatística e Análise Estatística da Decisão.

\section{RENAN SANTOS DESTEFANI}

Cursando Gestão Empresarial pela Fatec Rubens Lara, com previsão de término para o ano de 2019. Domínio avançado do idioma inglês. Participação de palestras ministradas na faculdade, com profissionais atuantes no mercado de trabalho da área administrativa. Conhecimento avançado das ferramentas do Pacote Office.

\section{RICARDO GHANTOUS CERVI}

Possui Graduação em Administração - Habilitação Comércio Internacional pela Universidade do Sagrado Coração (2004), Mestrado e Doutorado em Agronomia (Energia na Agricultura) pela Universidade Estadual Paulista. Atualmente é Professor Assistente Doutor da Universidade Estadual Paulista Câmpus Experimental de Itapeva.

\section{RICARDO VENTURINELI}

Ricardo Venturineli é Bacharel e Especialista em Engenharia de Produção pela Universidade Nove de Julho, Especialista em Gestão Logística pela Universidade Braz Cubas e em Docência e Gestão no Ensino a Distância pela Universidade Estácio de Sá. Possui experiência em engenharia na indústria automobilística e, na área acadêmica, em mediação, supervisão e tutoria pedagógicas em cursos de graduação de Engenharia de Produção. Cursa atualmente Licenciatura em Física e em Pedagogia, Especialização em Formação Pedagógica para o Ensino Profissional de Nível Médio e Mestrado em Engenharia Civil pela UNICAMP.

\section{RITA DE CASSIA COSTA DA SILVA HOLANDA}

Letras Licenciatura/Bacharelado Português/Inglês - Faculdade Universidade Paulista UNIP Técnólogo em Logística pela Fatec Zona Sul

\section{ROBERTA DE OLIVEIRA CABRERA}

Mestranda - Mestrado Profissional em Gestão e Tecnologia de Sistemas Produtivos - Unidade de Pós Graduação, Pesquisa e Extensão do Centro Estadual de Educação Tecnológica Paula Souza (previsão de conclusão mar/2019). Especialista na área de Marketing pela Universidade Presbiteriana Mackenzie (2006). Licenciada pela FATEC São Bernardo do Campo (2013). Graduada em Administração de Empresas, com habilitação em Marketing e Recursos Humanos pelo Centro Universitário Fundação Santo André (2002). Experiência profissional de 17 anos nas áreas de Administração e Marketing em empresas nacionais e multinacionais. Atuação em projetos especiais com equipes multifuncionais e virtuais. Fluência nos idiomas inglês e espanhol. Docente titular do Centro de Educação Tecnológica Paula Souza, desde 2010. 


\section{SANZARA NHIAIA JARDIM COSTA HASSMANN}

Bacharel em Matemática Aplicada e Computacional pela Universidade Federal do Rio Grande do Sul (1998), Mestrado (2001) e Doutorado (2006) em Matemática Aplicada na área de Vibrações e Controle pela Universidade Federal do Rio Grande do Sul. Pós doutorado em Dinâmica Não-linear e Caos pelo DEMAC/UNESP (2008), Atualmente trabalha com ensino e pesquisa na Fatec Jacareí e Fatec São José dos Campos. Empreendedora digital e Diretora de Conteúdos para os cursos presenciais e online do site Aprenda por Exercícios e Mathzap. Tem experiência em ensino e pesquisa nas áreas de análise numérica, computação simbólica, álgebra matricial, dinâmica não-linear e caos, estatística aplicada e geoestatística com R e R Studio.

\section{SARA SILVA DUARTE}

Graduanda em Ciências Contábeis pela UNINOVE - Universidade Nove de Julho e formada no Curso Técnico de Gestão Empresarial pelo Projeto Avança Brasil. Trabalha há 4 anos na área contábil. Atualmente, é Assistente de Contabilidade na empresa Mazars Cabrera - BR e atua como Educadora Social pelo Programa Escola da Família, projeto administrado pela FDE Fundação para o desenvolvimento da Educação.

\section{SERGIO AUGUSTO RODRIGUES}

Possui bacharelado (1997) e mestrado em Estatística (2003) pela Universidade Federal de São Carlos (UFSCar). É pós-graduado em Administração com ênfase em Marketing pela Universidade São Francisco - campus São Paulo (2000) e doutor pelo programa de Energia na Agricultura da Faculdade de Ciências Agronômicas - Universidade Estadual Paulista (UNESP Botucatu). Tem experiência na área de Probabilidade e Estatística com ênfase em Estatística Aplicada e pesquisa de mercado, atuando principalmente nos seguintes temas: amostragem, modelagem estatística, estatística multivariada e aplicação da estatística em bioprocessos para tratamento de resíduos e geração de energia.

\section{SIMONE SEIXAS PICARELLI}

A Professora Simone Seixas Picarelli possui Bacharelado em Física pela Universidade de São Paulo (USP), Mestrado e Doutorado em Oceanografia pela USP, Licenciatura em Física pela Universidade Virtual do Estado de São Paulo (UNIVESP) e, atualmente, cursa Especialização em Docência e Gestão na Educação a Distância pela Universidade Estácio de Sá. Trabalha como Professora Assistente nas Faculdades Integradas Campos Salles (FICS), ministrando aulas de Matemática e Estatística nos cursos de Administração e Cursos Superiores de Tecnologia.

\section{THAIS MASAGUE MIZANI}

Formado em Tecnologia em Logística - Fatec Mauá

\section{VALQUIRIA RIBEIRO DE SOUZA}

Tecnóloga em Logística pela FATEC-Botucatu-SP

\section{VANESSA CRISTINA GATTO CHIMENDES}

Possui graduação em Ciências Econômicas pelo Centro Universitário Toledo (1996) . Especialização em Administração Financeira e Auditoria na Universidade de Taubaté (2000). Especialização em Gestão da Produção na Universidade Estadual Paulista Julio de Mesquita Filho - UNESP / Guaratinguetá (2003). Mestre em Engenharia de Produção pela Universidade Federal de Itajubá (2007). Doutora em Engenharia Mecânica pela Universidade Estadual Júlio 
de Mesquita Filho - UNESP/ Guaratinguetá, com especialidade em economia da tecnologia. Professora III/D na Faculdade de Tecnologia de Guaratinguetá - FATEC.

\section{VANINA CARRARA SIGRIST}

Professora de Ensino Superior Nível III C na Faculdade de Tecnologia da Baixada Santista (FATEC-RL), licenciada em Letras, mestre e doutora em Teoria e História Literária pela UNICAMP. É membro da Comissão de Iniciação Científica na FATEC-RL. Tem experiência na área de comunicação, metodologia e redação científica, revisão e tradução da língua francesa.

\section{VANUSA MARISA CARVALHO MAGALHÃES ROCHA}

Graduanda no curso de ciências contábeis pela universidade nove de julho. Empresária atuando no ramo de decorações e eventos na cidade de São Paulo, desde o ano 2000.

\section{VINICIUS CARVALHO FERNANDES ASSIS}

Graduando do Curso de Ciências Contábeis pela UNINOVE - Universidade Nove de Julho. Especialista em Hedge accounting pela FIPECAFI. Trabalha a 2 anos na área contábil, com experiencia em contabilidade das entidades fechadas de previdência complementar na Mercer. E atualmente, na Deloitte fazendo a implantação da IFRS 16.

\section{VITOR LUÍZ MONTEIRO JÚNIOR}

Graduado em Tecnologia em Geoprocessamento, Técnico de Meio Ambiente e pósgraduando em Engenharia de Software, já atuou profissionalmente em diversos projetos de restituição e classificação de base cartográfica digital vetorial a partir da interpretação de mosaicos de imagens de satélites. Tais projetos foram calcados em normativas como a Especificação Técnica para a Estruturação de Dados Geoespaciais Vetoriais e a Especificação Técnica para a Aquisição de Dados Geoespaciais Vetoriais. Além disso, também possui experiência com modelagem de banco de dados espacial.

\section{VIVIANE FREIRE DOS SANTOS}

Cursou o $1^{\circ}$ semestre de Gestão Financeira. Atualmente pretende seguir na carreira militar.

\section{WADNA KIMBERLLY DA SILVA ALVES}

Pós graduanda em Gestão da Produção em Logística pelo Instituto Brasileiro de Formação IBF. Graduanda em Tecnologia em Logística pelo Instituto Federal de Educação, Ciência e Tecnologia do Amazonas - IFAM. Técnica em Administração pelo Instituto Federal de Educação, Ciência e Tecnologia do Rio Grande do Norte - IFRN. Linhas de pesquisa: Gestão da produção, Logística empresarial, Gestão Ambiental/Sustentabilidade e Logística Reversa.

\section{WAGNER DELMO ABREU CROCE}

Engenheiro de Produção pela Escola Politécnica da USP e economista pela Faculdade de Economia e Administração da USP, MBA com ênfase em Logística pela FGV e Mestre em Gestão de Sistemas Produtivos pelo Centro Paula Souza. 25 anos de experiência como executivo em indústrias de grande porte nacionais e multinacionais nas áreas de Controladoria e Finanças, Engenharia e Gestão da Cadeia de Abastecimento. Consultor independente há 15 anos nos setores industriais, comerciais, de serviços e governamentais. Professor de ensino superior há 12 anos, palestrante e conferencista. 


\section{YARA CRISTINA COSTA ROCHA MIRANDA}

Mestrado em Planejamento e Desenvolvimento Regional - Universidade de Taubaté(2014), possui Especialização de Processamento de Dados na Universidade de Taubaté(1989), Graduação em Bacharelado Análise de Sistemas Administrativos em Processamento de Dados pela Pontifícia Universidade Católica de Campinas (1981) e graduação em Administração de Empresas pela Faculdade de Administração Ciências Econômicas e Contábeis de Guaratinguetá (1990). Atualmente é professor pleno da Faculdade de Tecnologia de Guaratinguetá, ministra disciplina de Informática nos cursos de Gestão Empresarial, Gestão Financeira e Logística. Tem experiência na área de Ensino à Distância, Ciência da Computação, Implantação de Sistemas e Redes de Computadores. 


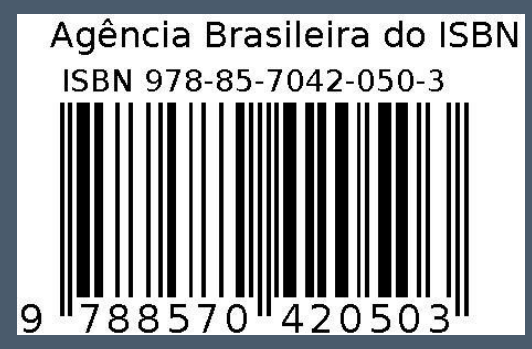

